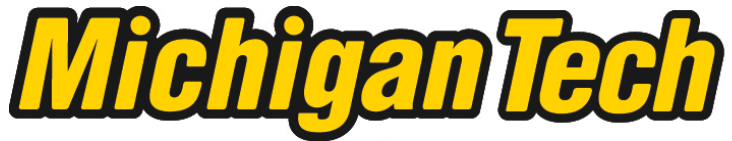 \\ Michigan Technological University Create the Future Digital Commons @ Michigan Tech
}

2013

DETERMINATION OF BULK DENSITY OF ROCK CORE USING STANDARD INDUSTRY METHODS

Kacy Mackenzey Crawford

Michigan Technological University

Follow this and additional works at: https://digitalcommons.mtu.edu/etds

Copyright 2013 Kacy Mackenzey Crawford

\section{Recommended Citation}

Crawford, Kacy Mackenzey, "DETERMINATION OF BULK DENSITY OF ROCK CORE USING STANDARD INDUSTRY METHODS", Master's report, Michigan Technological University, 2013.

https://doi.org/10.37099/mtu.dc.etds/661 


\title{
DETERMINATION OF BULK DENSITY OF ROCK CORE USING STANDARD INDUSTRY METHODS
}

By

Kacy Mackenzey Crawford

\begin{abstract}
A REPORT
Submitted in partial fulfillment of the requirements for the degree of MASTER OF SCIENCE In Civil Engineering
\end{abstract}

MICHIGAN TECHNOLOGICAL UNIVERSITY

(C) 2013 Kacy M. Crawford 
This report has been approved in partial fulfillment of the requirements for the Degree of MASTER OF SCIENCE in Civil Engineering

Department of Civil and Environmental Engineering

\author{
Report Co-Advisor: Stanley J Vitton \\ Report Co-Advisor: Theodore Bornhorst
}

Committee Member: Thomas Oommen

Department Chair: David Hand 


\section{Table of Contents}

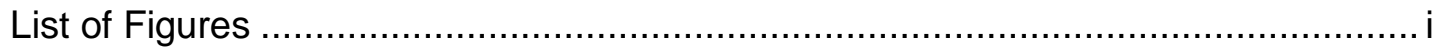

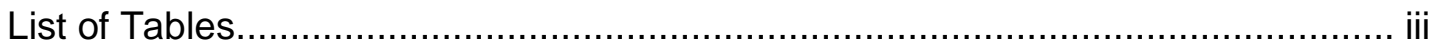

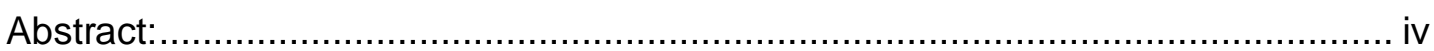

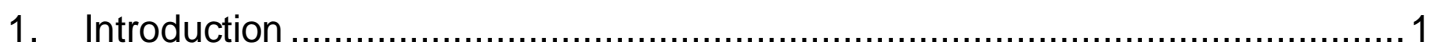

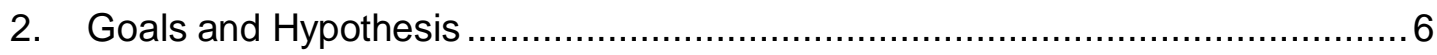

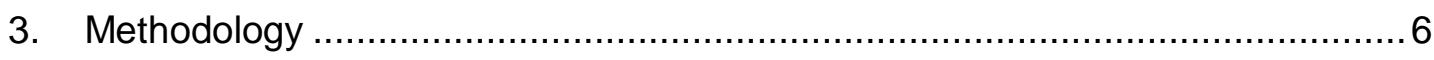

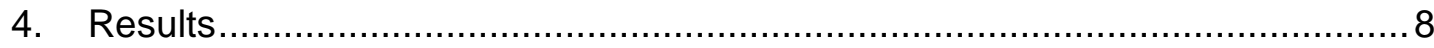

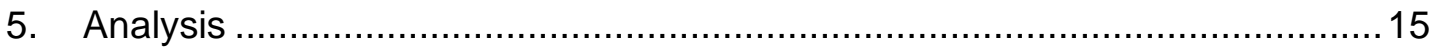

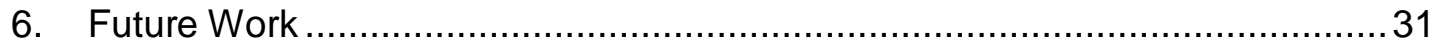

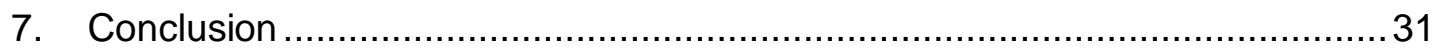

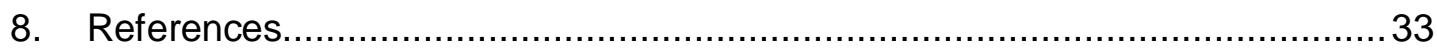

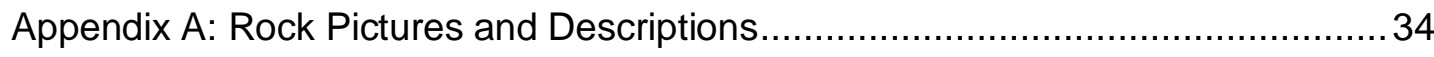

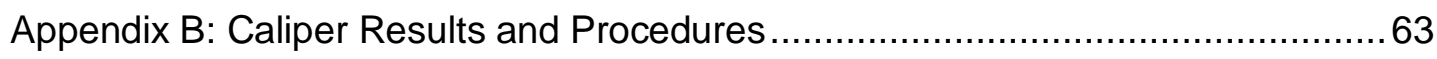

Appendix D: Wax Immersion Results and Procedures ..........................................91

Appendix E: Wax-Shrink Wrap Immersion Results and Procedures ..................... 106

Appendix F: Saturated Surface Dry (SSD) Results and Procedures...................... 122

Appendix G: Helium Pycnometer Results and Run Data ................................... 128

Appendix H: Raw Data for Water Immersion Trials ........................................... 192 


\section{List of Figures}

Figure 1-1: Schematic of the determination of the bulk density of a sample showing the difference between the different void volumes.

Figure 1-2: Schematic of the determination of a particle density of a core sample ................ 3

Figure 5-1: Indicated Porosity Graph for sample number 1-1-1, Granite ........................... 17

Figure 5-2: Indicated Porosity Graph for sample number 1-1-4, Granite .......................... 18

Figure 5-3: Indicated Porosity Graph for sample number 2-1-4, Kona Dolomite .................. 18

Figure 5-4: Indicated Porosity Graph for sample number 2-2-5, Kona Dolomite.................. 19

Figure 5-5: Indicated Porosity Graph for sample number 3-2-1, Pelkie Dolomite................. 19

Figure 5-6: Indicated Porosity Graph for sample number 3-3-2, Pelkie Dolomite................. 20

Figure 5-7: Indicated Porosity Graph for sample number 4-1-1, Various Carbonates ..........20

Figure 5-8: Indicated Porosity Graph for sample number 4-1-2, Various Carbonates ..........21

Figure 5-9: Indicated Porosity Graph for sample number 4-1-5, Various Carbonates ..........21

Figure 5-10: Indicated Porosity Graph for sample number 4-2-1, Various Carbonates ........ 22

Figure 5-11: Indicated Porosity Graph for sample number 4-2-3, Various Carbonates ........ 22

Figure 5-12: Indicated Porosity Graph for sample number 4-3-3, Various Carbonates ........ 23

Figure 5-13: Indicated Porosity Graph for sample number 4-4-2, Various Carbonates ........ 23

Figure Figure 5-14: Indicated Porosity Graph for sample number 5-1-1, Water Cooled Slag

Figure 5-15: Indicated Porosity Graph for sample number 5-1-3, Water Cooled Slag.......... 24

Figure 5-16: Indicated Porosity Graph for sample number 5-1-4, Water Cooled Slag.......... 25

Figure 5-17: Indicated Porosity Graph for sample number 5-2-1, Water Cooled Slag.......... 25

Figure 5-18: Indicated Porosity Graph for sample number 5-2-2, Water Cooled Slag.......... 26

Figure 5-19: Indicated Porosity Graph for sample number 5-2-3, Water Cooled Slag......... 26 
Figure 5-20: Indicated Porosity Graph for sample number 5-3-1, Water Cooled Slag..........27

Figure 5-21: Indicated Porosity Graph for sample number 5-3-3, Water Cooled Slag..........27

Figure 5-22: Indicated Porosity Graph for sample number 6-1-8, Jacobsville Sandstone .... 28

Figure 5-23: Indicated Porosity Graph for sample number 6-1-9, Jacobsville Sandstone ... 28

Figure 5-24: Indicated Porosity Graph for sample number 6-1-12, Jacobsville Sandstone .. 29

Figure 5-25: Indicated Porosity Graph for sample number 7-2, Air Cooled Slag................. 29

Figure 5-26: Indicated Porosity Graph for sample number 7-5, Air Cooled Slag................. 30

Figure 5-27: Indicated Porosity Graph for sample number 7-6, Air Cooled Slag................. 30 


\section{List of Tables}

Table 4-1: Combined bulk density results for Rock Type 1 (Granite) reported in $\mathrm{g} / \mathrm{cm}^{\wedge} 3 \ldots \ldots .8$

Table 4-2: Combined bulk density results for Rock Type 2 (Kona Dolomite) reported in

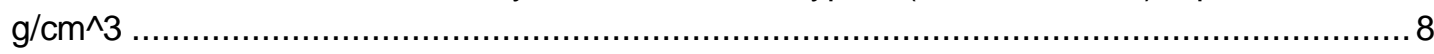

Table 4-3: Combined bulk density results for Rock Type 3 (Pelkie Dolomite) reported in $\mathrm{g} / \mathrm{cm}^{\wedge} 3$

Table 4-4: Combined bulk density results for Rock Type 4 (Various Carbonates) reported in $\mathrm{g} / \mathrm{cm}^{\wedge} 3$ 9

Table 4-5: Combined bulk density results for Rock Type 5 (Water Cooled Slag) reported in $\mathrm{g} / \mathrm{cm}^{\wedge} 3$

Table 4-6: Combined bulk density results for Rock Type 6 (Jacobsville Sandstone) reported in $\mathrm{g} / \mathrm{cm}^{\wedge} 3$. 10

Table 4-7: Combined bulk density results for Rock Type 7 (Air Cooled Slag) reported in $\mathrm{g} / \mathrm{cm}^{\wedge} 3$ 11

Table 4-8: Combined particle density results for Rock Type 1, Granite, in $\mathrm{g} / \mathrm{cm}^{\wedge} 3$ 11

Table 4-9: Combined particle density results for Rock Type 2, Kona Dolomite, in g/cm^3 ... 12 Table 4-10: Combined particle density results for Rock Type 3, Pelkie Dolomite, in g/cm^3 12 Table 4-11: Combined particle density results for Rock Type 4, Various Cabonates, in $\mathrm{g} / \mathrm{cm}^{\wedge} 3$

Table 4-12: Combined particle density results for Rock Type 5, Water Cooled Slag, in $\mathrm{g} / \mathrm{cm}^{\wedge} 3$

Table 4-13: Combined particle density results for Rock Type 6, Jacobsville Sandstone, in $\mathrm{g} / \mathrm{cm}^{\wedge} 3$ 14

Table 4-14: Combined particle density results for Rock Type 7, Air Cooled Slag, in g/cm^3 14 


\section{Abstract:}

Density is a basic property of a material that is equal to the objects mass divided by its volume. However the determination of an accurate density for some rock materials can difficult. This difficulty comes from many sources such as irregular volume, porosity, moisture content of the material, permeability of the material and the lack of a clear definition of density itself. This research investigated a common industry method used to determine the bulk density of rock core samples typically encountered in the mining industry. The main problem in determining the bulk density of rock core is obtaining an accurate estimate of the rock core's total volume. The research investigated four common techniques used to measuring the bulk density of materials. The research also investigated the issue of moisture saturation into the rock core. This is an important parameter in the portioning of concrete mixes. This density is known as the saturated-surface-dry density.

Testing was completed using a suite of seven different kinds of rock that ranged from highly competent granite and dolomites to highly permeable sandstone and blast furnace slag that contained a large volume of internal pore space.

Four different methods commonly used in the aggregate and mining industries to determine the bulk density of materials were examined. These methods were the caliper method, instantaneous water immersion method, wax immersion method, and wax-shrink wrap immersion. Of the four methods tested the wax-immersion method was determined to be the most accurate method. This was due to the liquid waxes ability to closely mold into the surface pore of the sample which gives the most accurate estimate of the volume of the sample.

The particle density of the materials used in this research were determined using an automated helium gas pycnometer, which is considered an industry standard. The saturated-surface-dry density used in the aggregate industry is outlined in ASTM C127-07 (Standard Test Method for Density, Relative Density (Specific Gravity), and Absorption of Coarse Aggregate). Testing revealed that ASTM C127-07 does not accurately represent the particle density of the material due to the large surface pores where, mainly in the blast slag samples. 


\section{Introduction}

Density is a basic property of a material and is defined as mass divided by volume. While the definition is straightforward, the determination of an accurate and reliable value of a material's density can be difficult to achieve in some circumstances. For example, objects that consist of irregular shapes that are highly fractured and made up of many pieces can cause difficulties in determining an accurate volume and thus the density. In most cases, it is not the determination of the mass of the object, but the volume, which poses a significant challenge in obtaining an accurate density.

The definition of density is further complicated by a number of alternate definitions of density. This is illustrated by the American Society for Testing and Materials (ASTM) whose standard book of definitions has more than 40 definitions of density based on the concept of mass per a unit volume. The British Standards Institute has narrowed the field slightly, but still has 14 unique kinds of density (Webb, 2001). While most of these definitions are relatively straightforward, it can become confusing when different disciplines use different terminology to describe the various types of density.

To those working with aggregates, the concept of density or specific gravity is also extremely important. For example density is used to determine quantities and proportioning during design and construction work. While the purpose and concept of density is the same for all materials, there are a number of different definitions that are commonly used. For example, in making concrete, ASTM standards define three types of density that are outlined in ASTM C127-07 (Standard Test Method for Density, Relative Density (Specific Gravity), and Absorption of Coarse Aggregate). These three densities are used to calculate the portions of water, cement, and aggregated needed to properly make concrete. The three densities differ, however by how the void space in the material is handled such as whether the void space is part of the volume and whether the void space is saturated or dry. Therefore, the densities will differ by the amount of void space in the material and to an extent how much water occupies the void spaces. Are the voids wet? Dry? Included or excluded? This leads to three different approaches in defining density. (ASTM, 2009)

In calculating the density of a material the mass term is straightforward, while the volume term can be difficult. For example, a rock core that has been cut on either end to create a cylinder can simply utilize the basic geometric equation for a cylinder to determine the material's volume. Using a caliper, the diameter and length of the core can be determined 
and a density calculated once the mass or weight is determined. This, however, relies on a pretty broad assumption that the surface of the rock is perfectly smooth, and contains no imperfections or voids along the surface of the sample. For most materials this is not a correct assumption, since almost all samples will have some surface irregularity, which can increase or decrease the volume when assuming the volume is a cylinder. While some materials may have smooth surfaces with minimal voids along the surface, other materials that have rough surfaces or deeply seated surface pores can affect the determination of volume, which will then affect the accuracy of the determination of a material's density.

While this may be perceived as a relatively minor problem, in some industries and situations, a small error in density can cause wide systematic errors. In mining and aggregate industries having an inaccurate density can lead to significant problems. For example, no industry relies on accurate density calculations more than the precious mineral industry for calculating the tons of ore available in a mine. Surveys of operating gold mines in Canada and Australia show that many mines never hit the production goals that were estimated during exploration based on the density and assay results of their respective drilling programs. In Australia, only two thirds of the 35 mines surveyed (which opened between 1984 and 1987) met the estimated production goal during the first year of operation and production. Out of the 35 mines studied, only two met the estimated grade of ore during production. This problem was also identified in many mines in Canada (Dominy, 2002). One of the main issues identified was the determination of the bulk density of the rock core samples, where the bulk density was defined as mass or weight of a material divided by the total volume of the material including the voids contained within the volume.

This report will define the bulk density as the density of a sample that includes both the solid particle fraction of the soil, as well as the internal and surface pore space of the sample. (Dominy, 2002). While there are several methods currently available to determine the bulk density of a sample, they may not be viable over a wide range of sample sizes, porosities and permeability's. This concept is separate from a particle density or specific gravity, which is the density of the particles making up the substance, not including the voids in the sample.

The difference between bulk density and the particle density (specific gravity) can be seen in the following figures. Figure 1-1 shows a material composed of solids and a separation of the void volume into a "surface" pore volume and an inter-particle void volume. In the determination of bulk density, only the internal pores of the material are included in the volume. Consequently, the material's surface pores are not included in the volume determination of bulk density. 


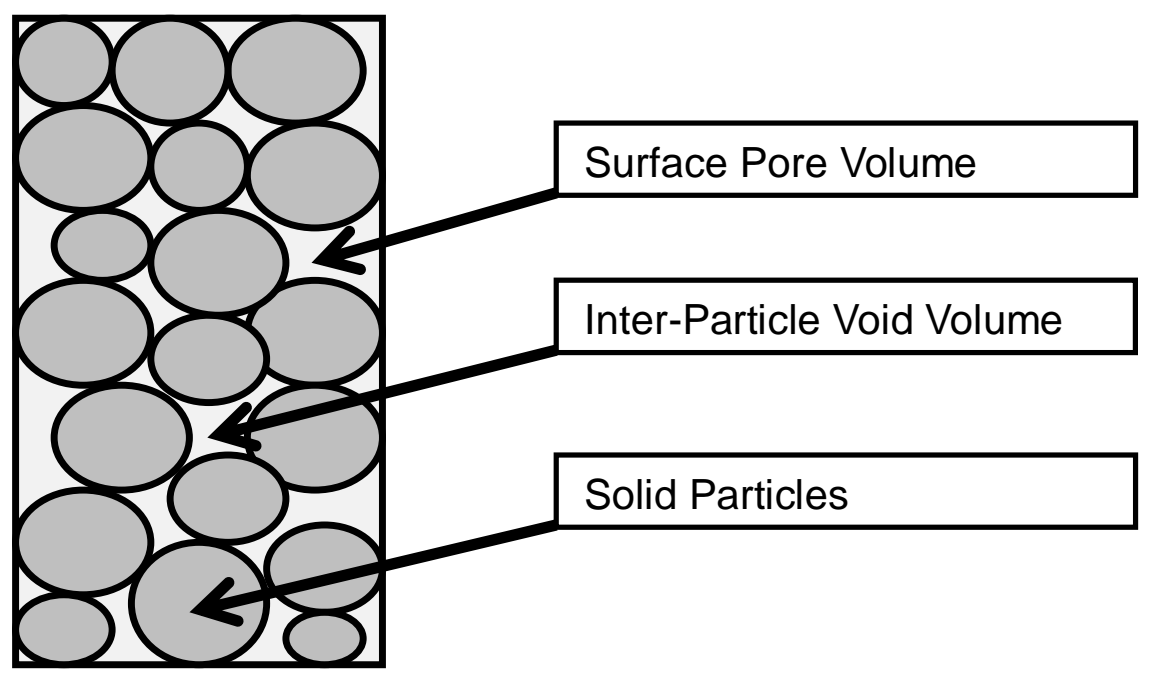

Figure 1-1: Schematic of the determination of the bulk density of a sample showing the difference between the different void volumes

The particle density, which is directly related to the specific gravity of a material, represents the density of only the solid portion of the sample. Therefore, the particle density is determined by dividing the particle mass by the particle volume and does not include the voids within the material. This is shown in Figure 1-2.
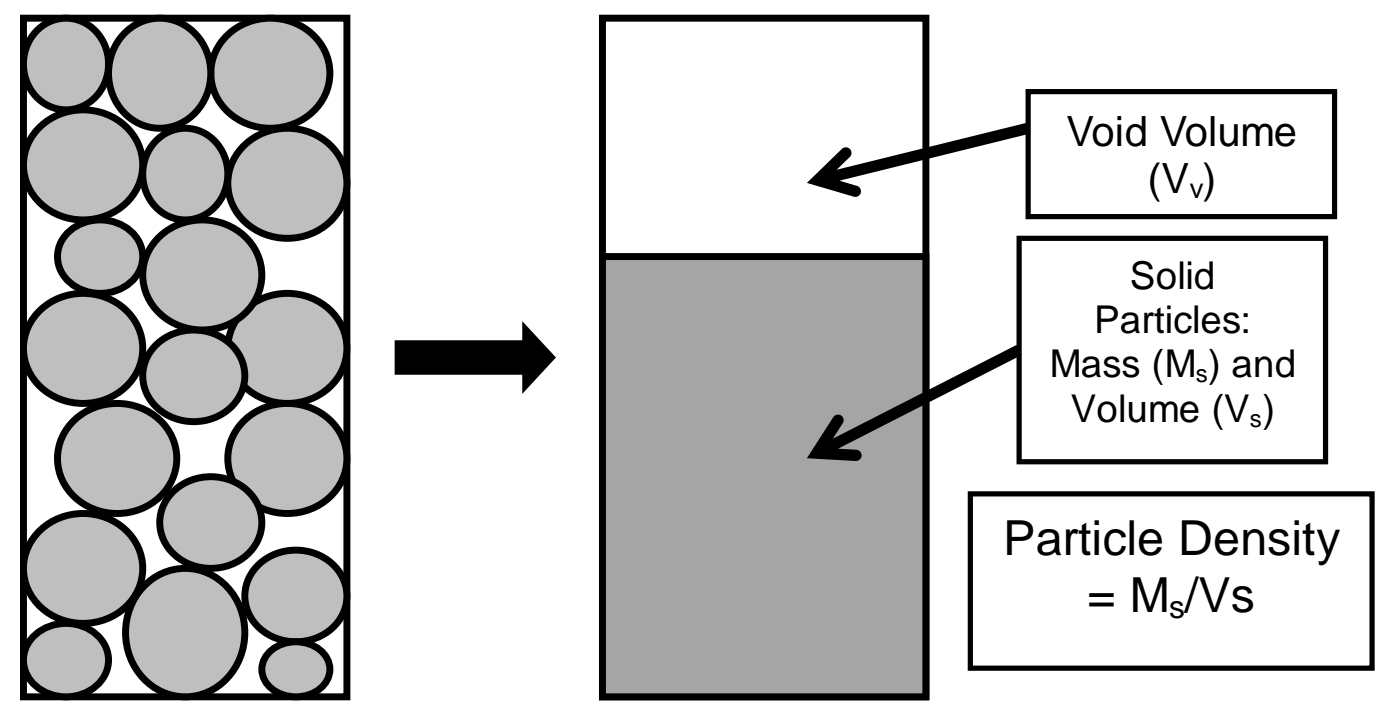

Figure 1-2: Schematic of the determination of a particle density of a core sample 
The issue of accurate bulk density, particle density and absorption measurements can also be experienced when working with aggregates. Not determining the correct parameters of the aggregate used in a concrete mix can cause problems with the mix or using the wrong aggregate resulting in improper concrete properties such as a decrease concrete strength. Also, not calculating the correct bulk density of the material can cause serious problems when estimating the mass of aggregate based off of a volumetric measurement.

Today, there are several automated and manual methods for determining both the bulk and particle density of a material. For example, an automated helium pycnometer, which uses helium gas to determine the volume of a material, can be used to determine the particle density or specific gravity of a material (S. J. Vitton, Lehman, M.A., Van Dam, T.J., 1998). Helium pycnometers are widely used in industry although they are limited in many cases to smaller sample sizes in the order of $1000 \mathrm{~cm}^{3}$ or smaller. The helium pycnometer provides a very accurate determination of a particles density and in some industries such as in the Powder Metallurgy field it is considered an industry standard. Automated bulk density instruments have also been developed that provide very good estimates of the bulk density of a material. The issue with both of these methods, however, is that it is difficult to measure the density of typical rock core generated from standard drilling operations due to the size limitations of the equipment. Typical rock core in general have a one to two inch diameter with variable lengths and cannot in general be tested without breaking down the rock core to fit into the instruments. In addition, there are no ASTM standards available for using these instruments. While standards exist to determine the bulk and particle density of aggregate as noted above, there are no ASTM standards available for the determine of bulk density of a rock core sample. As noted above, the estimate of bulk density is an important parameter. The measurement of bulk density for the mineral industry is very important for an accurate determination of the amount of ore available in a deposit.

Another issue, generally not encountered in the aggregate industry, is the rules and regulations involved in the assessment of ore deposits. For example, mining companies in Canada are now required to follow a codified set of rules and guidelines for reporting and displaying information related to mineral properties known as the National Instrument 43-101 (the "NI 43-101" or the "NI") for the Standards of Disclosure for Mineral Projects within Canada. These rules were developed to eliminate fraud in the assessment of ore deposits such as precious and base metals deposits. The standards are now being used worldwide in the assessment of almost all mining related projects and especially for public companies that are listed on various stock exchanges in the United States. An important feature of these rules is maintaining a strict change-of-custody for all ore samples taken from a 
potential ore deposit, which in general are in the form of rock cores. Therefore, density measurements need to be determined while in the chain-of-custody of the rock cores.

Rock cores from mining exploration projects have a number of uses including estimating the amount of minerals in the deposit, the ore's metallurgical properties, and strength properties. In addition, a section of the core must generally be maintained for archival purposes. To accomplish this, the core is generally cut into quarters know as quartering. In general, the bulk density of a rock core must be determined before the core is quartered, since the bulk density of the core becomes an important quantity used to determine the amount of ore that is present in the ore body. Therefore, the determination of density must be accomplished within a short period of time since the rock core once obtained is quickly cut and sent out for analysis. Again, this must all be accomplished under a strict change-of-custody set of rules that include that the rock core must not be in any way be contaminated or compromised by the testing processes.

As noted above, there are no ASTM standards available for the measurement of bulk density of rock core nor have there been studies conducted to determine the accuracy of the methods currently used to determine the bulk density of rock core. These standards include the standard caliber method, water immersion, wax coating as well other lesser known methods.

Some of the issues involved in the methods used to measure the bulk density of rock core are as follows. First, the method must not cause damage to the core if additional testing needs to be completed at a later date. Second, the method must not contaminate the core. While not as important in the aggregate industry, this is extremely important to the mineral exploration industry. Still being able to assay a sample at a later date is very important in order to determine mineral content. Third, the method needs to provide a quick and economical determination of the rock core's density and be applicable to a wide variety of rock types. And fourth, the method must provide an accurate determination, as well as be repeatable and not be operator dependent.

Currently, the main methods used for the determination of bulk density of rock core still need to be done by hand, and few of those methods are applicable to larger irregular pieces of rock. Again as noted above, there are no comprehensive standards to follow that address the potential issues in the determination of a correct bulk density. For example, a sample with very large surface pores will need to be treated in a different manner than a sample composed of little to no open pore space on the surface of the sample. Likewise, a rock that 
is almost impermeable will require different testing than a sample that is highly permeable. Another drawback to larger sample sizes is that many of the automated methods available today do not work well with larger sample sizes. Consequently, the main purpose of this research is to assess the accuracy of some of the more commonly used methods to determine the bulk density of rock core. A secondary purpose of this research was to investigate the effect of moisture penetration into rock cores in estimating the saturatedsurface- dry density used in the making of concrete.

\section{Goals and Hypothesis}

The main goal of this research is to assess the accuracy of the methods used to determine the bulk density of rock core. A collection of rocks representing a diverse range of porosities, permeability's, and rock types were tested using the four methods.

The four methods that were evaluated for the determination of bulk density of rock core include:

- Caliper Method

- Instantaneous Water Immersion

- Wax Immersion

- Wax-Shrink Wrap Immersion method

For particle density a helium pycnometer was used. An additional density known as the "saturated surface dry density", generally used for the portioning and mixing of concrete but also with applications for the assessment of metallurgic properties of ore was also investigated in this research.

\section{Methodology}

Four methods used to determinate bulk density of rock core were investigated in this research using seven diverse rock types. The particle density (specific gravity) and the surface-saturated-dry density, which is used in the design of a concrete mix, were also conducted investigated on the seven rock types. The rocks selected were chosen to help represent a wide variety of porosities, pore structures, permeability and hardness. A 
complete description of the rock types is provided in Appendix A, which includes photos of the individual cores, and a description of how the samples were prepared.

The four methods of bulk density investigated were the (1) caliper, (2) instantaneous water immersion, (3) wax immersion, and (4) wax-shrink wrap immersion. The procedures followed for each of these methods are described in the Appendix of this report. The Caliper Method is located in Appendix B, the Instantaneous Water Immersion in Appendix C. the wax Immersion and Wax -Shrink Wrap Immersion in Appendix D and Appendix E respectively.

The particle density (specific gravity) was determined using an automated helium gas pycnometer. The Saturated Surface Dry (SSD) method followed the ASTM C127 standard. The procedure and results for the SSD Method are presented in Appendix F. Run settings and full results for the gas pycnometer (AccyPyc 1330) are presented in Appendix G.

Additional testing related to the SSD method was also conducted to assess the time required to saturate the rock core. The testing was conducted over a twenty four hour long period. Data points were collected at various points ranging from one to four hours. At each point, the samples were removed from the water, the water dried from the surface, and the weight recorded. The results of this testing are provided in Appendix $\mathrm{H}$, and the final graphs as well as a comparison to the Helium Pycnometer and SSD results are reported in the next section of this report.

Overall seven different rock types were tested in an attempt to represent common materials used for aggregates. These rocks ranged from very competent dolomites and granites, to highly porous materials such as air or water cooled blast slags. The seven rock types tested were:

- Granite

- Kona Dolomite

- Pelkie Dolomite

- Various Carbonates (Sampled from around lower Michigan)

- Water Cooled Blast Slag

- Jacobsville Sandstone

- Air Cooled Blast Slag 


\section{Results}

Tables 4-1 through 4-7 below contain the results of the bulk density testing by rock type. The value reported is the average value from the testing for the caliper method and for the Instantaneous Water Immersion, Wax Immersion and Wax-Shrink Wrap Immersion the value is the calculated value rounded to the hundredths place.

Table 4-1: Combined bulk density results for Rock Type 1 (Granite) reported in $\mathrm{g} / \mathrm{cm}^{3}$.

\begin{tabular}{|c|c|c|c|c|}
\hline \multirow{2}{*}{ Sample ID } & \multicolumn{4}{|c|}{ Table 4-1: Combined Results for Rock Type 1, Granite } \\
\cline { 2 - 5 } & Caliper & $\begin{array}{c}\text { Instantaneous Water } \\
\text { Immersion }\end{array}$ & $\begin{array}{c}\text { Wax Immersion } \\
\text { Method }\end{array}$ & $\begin{array}{c}\text { Wax-Shrink } \\
\text { Wrap } \\
\text { Immersion }\end{array}$ \\
\hline $1-1-1$ & 2.62 & 2.61 & 2.64 & 2.59 \\
\hline $1-1-2$ & 2.61 & 2.60 & 2.65 & 2.56 \\
\hline $1-1-4$ & 2.61 & 2.61 & 2.66 & 2.54 \\
\hline
\end{tabular}

Table 4-2: Combined bulk density results for Rock Type 2 (Kona Dolomite) reported in $\mathrm{g} / \mathrm{cm}^{3}$

\begin{tabular}{|c|c|c|c|c|}
\hline \multirow{2}{*}{ Sample ID } & \multicolumn{4}{|c|}{ Bulk Density Results by Method $\left(\mathrm{g} / \mathrm{cm}^{3}\right)$} \\
\cline { 2 - 5 } & Caliper & $\begin{array}{c}\text { Instantaneous Water } \\
\text { Immersion }\end{array}$ & $\begin{array}{c}\text { Wax Immersion } \\
\text { Method }\end{array}$ & $\begin{array}{c}\text { Wax-Shrink } \\
\text { Wrap } \\
\text { Immersion }\end{array}$ \\
\hline $2-1-1$ & 2.66 & 2.65 & 2.69 & 2.63 \\
\hline $2-1-2$ & 2.66 & 2.72 & 2.71 & 2.65 \\
\hline $2-1-3$ & 2.73 & 2.70 & 2.75 & 2.68 \\
\hline $2-1-4$ & 2.69 & 2.68 & 2.72 & 2.63 \\
\hline $2-2-1$ & 2.83 & 2.93 & 2.87 & 2.81 \\
\hline $2-2-2$ & 2.75 & 2.78 & 2.78 & 2.70 \\
\hline $2-2-3$ & 2.83 & 2.86 & 2.86 & 2.76 \\
\hline $2-2-4$ & 2.82 & 2.80 & 2.84 & 2.78 \\
\hline $2-2-5$ & 2.83 & 2.89 & 2.86 & 2.79 \\
\hline $2-2-6$ & 2.61 & 2.68 & 2.67 & 2.60 \\
\hline
\end{tabular}


Table 4-3: Combined bulk density results for Rock Type 3 (Pelkie Dolomite) reported in $\mathrm{g} / \mathrm{cm}^{3}$

\begin{tabular}{|c|c|c|c|c|}
\hline \multirow{4}{*}{ Sample ID } & \multicolumn{4}{|c|}{ Bulk Density Results by Method $\left(\mathrm{g} / \mathrm{cm}^{3}\right)$} \\
\cline { 2 - 5 } & Caliper & $\begin{array}{c}\text { Instantaneous Water } \\
\text { Immersion }\end{array}$ & $\begin{array}{c}\text { Wax Immersion } \\
\text { Method }\end{array}$ & $\begin{array}{c}\text { Wax-Shrink } \\
\text { Wrap } \\
\text { Immersion }\end{array}$ \\
\hline $3-2-1$ & 2.67 & 2.61 & 2.69 & 2.46 \\
\hline $3-3-1$ & 2.77 & 2.77 & 2.74 & 2.61 \\
\hline
\end{tabular}

Table 4-4: Combined bulk density results for Rock Type 4 (Various Carbonates) reported in $\mathrm{g} / \mathrm{cm}^{3}$

\begin{tabular}{|c|c|c|c|c|}
\hline \multirow{2}{*}{ Sample ID } & \multicolumn{4}{|c|}{ Bulk Density Results by Method $\left(\mathrm{g} / \mathrm{cm}^{3}\right)$} \\
\cline { 2 - 5 } & Caliper & $\begin{array}{c}\text { Instantaneous Water } \\
\text { Immersion }\end{array}$ & $\begin{array}{c}\text { Wax Immersion } \\
\text { Method }\end{array}$ & $\begin{array}{c}\text { Wax-Shrink } \\
\text { Wrap } \\
\text { Immersion }\end{array}$ \\
\hline $4-1-1$ & 2.56 & 2.78 & 2.78 & 2.64 \\
\hline $4-1-2$ & 2.73 & 2.80 & 2.77 & 2.67 \\
\hline $4-1-3$ & 2.70 & 2.74 & 2.74 & 2.67 \\
\hline $4-1-4$ & 2.75 & 2.77 & 2.76 & 2.71 \\
\hline $4-1-5$ & 2.74 & 2.77 & 2.77 & 2.68 \\
\hline $4-2-1$ & 2.67 & 2.70 & 2.69 & 2.60 \\
\hline $4-2-2$ & 2.65 & 2.68 & 2.68 & 2.58 \\
\hline $4-2-3$ & 2.62 & 2.66 & 2.64 & 2.58 \\
\hline $4-3-1$ & 2.76 & 2.81 & 2.74 & 2.58 \\
\hline $4-3-2$ & 2.68 & 2.73 & 2.73 & 2.64 \\
\hline $4-3-3$ & 2.66 & 2.75 & 2.73 & 2.62 \\
\hline $4-4-1$ & 2.65 & 2.67 & 2.67 & 2.56 \\
\hline $4-4-2$ & 2.62 & 2.69 & 2.64 & 2.53 \\
\hline $4-4-3$ & 2.65 & 2.68 & 2.67 & 2.58 \\
\hline $4-5-1$ & 2.65 & 2.71 & 2.68 & 2.62 \\
\hline & & & & \\
\hline
\end{tabular}


Table 4-5: Combined bulk density results for Rock Type 5 (Water Cooled Slag) reported in $\mathrm{g} / \mathrm{cm}^{3}$

\begin{tabular}{|c|c|c|c|c|}
\hline \multirow{3}{*}{ Sample ID } & \multicolumn{4}{|c|}{ Bulk Density Results by Method $\left(\mathrm{g} / \mathrm{cm}^{3}\right)$} \\
\cline { 2 - 5 } & Caliper & $\begin{array}{c}\text { Instantaneous Water } \\
\text { Immersion }\end{array}$ & $\begin{array}{c}\text { Wax Immersion } \\
\text { Method }\end{array}$ & $\begin{array}{c}\text { Wax-Shrink } \\
\text { Wrap } \\
\text { Immersion }\end{array}$ \\
\hline $5-1-1$ & 2.29 & 2.40 & 2.35 & 2.22 \\
\hline $5-1-2$ & 2.32 & 2.45 & 2.37 & 2.27 \\
\hline $5-1-3$ & 2.28 & 2.40 & 2.35 & 2.26 \\
\hline $5-1-4$ & 2.30 & 2.43 & 2.38 & 2.28 \\
\hline $5-1-5$ & 1.98 & 2.43 & 2.37 & 2.25 \\
\hline $5-2-1$ & 2.00 & 2.18 & 2.17 & 1.96 \\
\hline $5-2-2$ & 2.45 & 2.54 & 2.48 & 2.43 \\
\hline $5-2-3$ & 2.17 & 2.43 & 2.42 & 2.34 \\
\hline $5-2-5$ & 1.95 & 2.11 & 2.07 & 1.89 \\
\hline $5-3-1$ & 2.13 & 2.27 & 2.28 & 2.16 \\
\hline $5-3-2$ & 2.02 & 2.17 & 2.11 & 2.00 \\
\hline $5-3-3$ & 1.94 & 2.08 & 2.05 & 1.91 \\
\hline
\end{tabular}

Table 4-6: Combined bulk density results for Rock Type 6 (Jacobsville Sandstone) reported in $\mathrm{g} / \mathrm{cm}^{3}$

\begin{tabular}{|c|c|c|c|c|}
\hline \multirow{2}{*}{ Sample ID } & \multicolumn{4}{|c|}{ Bulk Density Results by Method (g/cm^3) } \\
\cline { 2 - 5 } & Caliper & $\begin{array}{c}\text { Instantaneous Water } \\
\text { Immersion }\end{array}$ & $\begin{array}{c}\text { Wax Immersion } \\
\text { Method }\end{array}$ & $\begin{array}{c}\text { Wax-Shrink } \\
\text { Wrap } \\
\text { Immersion }\end{array}$ \\
\hline $6-1-1$ & 2.11 & 2.18 & 2.14 & 2.06 \\
\hline $6-1-2$ & 2.11 & 2.18 & 2.15 & 2.10 \\
\hline $6-1-3$ & 2.10 & 2.17 & 2.13 & 2.03 \\
\hline $6-1-4$ & 2.10 & 2.17 & 2.14 & 2.09 \\
\hline $6-1-5$ & 2.10 & 2.15 & 2.12 & 2.06 \\
\hline $6-1-6$ & 2.11 & 2.17 & 2.13 & 2.09 \\
\hline $6-1-7$ & 2.11 & 2.16 & 2.14 & 2.05 \\
\hline $6-1-8$ & 2.10 & 2.17 & 2.13 & 2.06 \\
\hline $6-1-9$ & 2.10 & 2.16 & 2.13 & 2.04 \\
\hline $6-1-10$ & 2.09 & 2.16 & 2.12 & 2.07 \\
\hline $6-1-11$ & 2.09 & 2.16 & 2.13 & 2.07 \\
\hline $6-1-12$ & 2.11 & 2.17 & 2.14 & 2.09 \\
\hline
\end{tabular}


Table 4-7: Combined bulk density results for Rock Type 7 (Air Cooled Slag) reported in $\mathrm{g} / \mathrm{cm}^{3}$

\begin{tabular}{|c|c|c|c|c|}
\hline \multirow{5}{*}{ Sample ID } & \multicolumn{4}{|c|}{ Bulk Density Results by Method $\left(\mathrm{g} / \mathrm{cm}^{3}\right)$} \\
\cline { 2 - 5 } & Caliper & $\begin{array}{c}\text { Instantaneous Water } \\
\text { Immersion }\end{array}$ & $\begin{array}{c}\text { Wax Immersion } \\
\text { Method }\end{array}$ & $\begin{array}{c}\text { Wax-Shrink } \\
\text { Wrap } \\
\text { Immersion }\end{array}$ \\
\hline $7-1$ & 2.11 & 2.27 & 2.20 & 2.09 \\
\hline $7-2$ & 2.16 & 2.37 & 2.27 & 2.12 \\
\hline $7-3$ & 2.07 & 2.31 & 2.17 & 2.02 \\
\hline $7-4$ & 1.78 & 2.22 & 1.89 & 1.75 \\
\hline $7-5$ & 2.19 & 2.31 & 2.29 & 2.16 \\
\hline $7-6$ & 2.11 & 1.91 & 2.17 & 2.10 \\
\hline $7-7$ & 1.99 & 2.15 & 2.07 & 1.95 \\
\hline $7-8$ & 1.80 & 2.35 & 2.26 & 2.13 \\
\hline
\end{tabular}

Tables 4-8 to 4-14 below show the results of the two particle density methods tested. All the results are organized by the rock type and all units on the particle densities are in $\mathrm{g} / \mathrm{cm}^{3}$ and rounded to two decimal places

Table 4-8: Combined particle density results for Rock Type 1, Granite, in g/cm ${ }^{3}$

\begin{tabular}{|c|c|c|}
\hline \multicolumn{3}{|c|}{ Table 4-8: Combined Particle Density Results for Rock Type 1, Granite } \\
\hline $\begin{array}{c}\text { Sample } \\
\text { ID }\end{array}$ & Helium Pycnometer Results $\left(\mathrm{g} / \mathrm{cm}^{3}\right)$ & Saturated Surface Dry Method $\left(\mathrm{g} / \mathrm{cm}^{3}\right)$ \\
\hline $1-1-1$ & 2.64 & 2.64 \\
\hline $1-1-2$ & 2.64 & 2.65 \\
\hline $1-1-4$ & 2.64 & 2.64 \\
\hline
\end{tabular}


Table 4-9: Combined particle density results for Rock Type 2, Kona Dolomite, in g/cm ${ }^{3}$

\begin{tabular}{|c|c|c|}
\hline \multicolumn{3}{|c|}{ Table 4-9: Combined Particle Density Results for Rock Type 2, Kona Dolomite } \\
\hline $\begin{array}{c}\text { Sample } \\
\text { ID }\end{array}$ & Helium Pycnometer Results $\left(\mathrm{g} / \mathrm{cm}^{3}\right)$ & Saturated Surface Dry Method $\left(\mathrm{g} / \mathrm{cm}^{3}\right)$ \\
\hline $2-1-1$ & 2.68 & 2.68 \\
\hline $2-1-2$ & 2.68 & 2.70 \\
\hline $2-1-3$ & 2.75 & 2.75 \\
\hline $2-1-4$ & 2.75 & 2.71 \\
\hline $2-2-1$ & 2.85 & 2.86 \\
\hline $2-2-2$ & 2.72 & 2.77 \\
\hline $2-2-3$ & 2.83 & 2.86 \\
\hline $2-2-4$ & 2.85 & 2.84 \\
\hline $2-2-5$ & 2.86 & 2.86 \\
\hline $2-2-6$ & 2.72 & 2.67 \\
\hline
\end{tabular}

Table 4-10: Combined particle density results for Rock Type 3, Pelkie Dolomite, in $\mathrm{g} / \mathrm{cm}^{3}$

\begin{tabular}{|c|c|c|}
\hline \multicolumn{3}{|c|}{ Table 4-10: Combined Particle Density Results for Rock Type 3, Pelkie Dolomite } \\
\hline $\begin{array}{c}\text { Sample } \\
\text { ID }\end{array}$ & Helium Pycnometer Results $\left(\mathrm{g} / \mathrm{cm}^{3}\right)$ & Saturated Surface Dry Method $\left(\mathrm{g} / \mathrm{cm}^{3}\right)$ \\
\hline $3-2-1$ & 2.80 & 2.68 \\
\hline $3-3-1$ & 2.80 & 2.74 \\
\hline
\end{tabular}


Table 4-11: Combined particle density results for Rock Type 4, Various Carbonates, in $\mathrm{g} / \mathrm{cm}^{3}$ Table 4-11: Combined Particle Density Results for Rock Type 4, Various Carbonates

\begin{tabular}{|c|c|c|}
\hline $\begin{array}{c}\text { Sample } \\
\text { ID }\end{array}$ & Helium Pycnometer Results $\left(\mathrm{g} / \mathrm{cm}^{3}\right)$ & Saturated Surface Dry Method $\left(\mathrm{g} / \mathrm{cm}^{3}\right)$ \\
\hline $4-1-1$ & 2.83 & 2.77 \\
\hline $4-1-2$ & 2.83 & 2.78 \\
\hline $4-1-3$ & 2.83 & 2.37 \\
\hline $4-1-4$ & 2.83 & 2.76 \\
\hline $4-1-5$ & 2.82 & 2.77 \\
\hline $4-2-1$ & 2.85 & 2.68 \\
\hline $4-2-2$ & 2.84 & 2.68 \\
\hline $4-2-3$ & 2.81 & 2.64 \\
\hline $4-3-1$ & 2.84 & 2.73 \\
\hline $4-3-2$ & 2.83 & 2.73 \\
\hline $4-3-3$ & 2.81 & 2.72 \\
\hline $4-4-1$ & 2.81 & 2.66 \\
\hline $4-4-2$ & 2.81 & 2.63 \\
\hline $4-4-3$ & 2.86 & 2.66 \\
\hline $4-5-1$ & 2.86 & 2.68 \\
\hline
\end{tabular}

Table 4-12: Combined particle density results for Rock Type 5, Water Cooled Slag, in g/ $\mathrm{cm}^{3}$

\begin{tabular}{|c|c|c|}
\hline \multicolumn{2}{|c|}{ Table 4-12: Combined Particle Density Results for Rock Type 5, Water Cooled Slag } \\
\hline $\begin{array}{c}\text { Sample } \\
\text { ID }\end{array}$ & Helium Pycnometer Results $\left(\mathrm{g} / \mathrm{cm}^{3}\right)$ & Saturated Surface Dry Method $\left(\mathrm{g} / \mathrm{cm}^{3}\right)$ \\
\hline $5-1-1$ & 2.93 & 2.39 \\
\hline $5-1-2$ & 2.96 & 2.32 \\
\hline $5-1-3$ & 2.95 & 2.30 \\
\hline $5-1-4$ & 2.95 & 2.41 \\
\hline $5-1-5$ & 2.96 & 2.32 \\
\hline $5-2-1$ & 2.97 & 2.08 \\
\hline $5-2-2$ & 2.91 & 2.49 \\
\hline $5-2-3$ & 2.92 & 2.38 \\
\hline $5-2-5$ & 2.93 & 2.07 \\
\hline $5-3-1$ & 2.95 & 2.25 \\
\hline $5-3-2$ & 2.95 & 2.06 \\
\hline $5-3-3$ & 2.95 & 2.01 \\
\hline
\end{tabular}


Table 4-13: Combined particle density results for Rock Type 6, Jacobsville Sandstone, in $\mathrm{g} / \mathrm{cm}^{3}$

\begin{tabular}{|c|c|c|}
\hline \multicolumn{2}{|c|}{ Table 4-13: Combined Particle Density Results for Rock Type 6, Jacobsville Sandstone } \\
\hline $\begin{array}{c}\text { Sample } \\
\text { ID }\end{array}$ & Helium Pycnometer Results $\left(\mathrm{g} / \mathrm{cm}^{3}\right)$ & Saturated Surface Dry Method $\left(\mathrm{g} / \mathrm{cm}^{3}\right)$ \\
\hline $6-1-1$ & 2.65 & 2.21 \\
\hline $6-1-2$ & 2.64 & 2.13 \\
\hline $6-1-3$ & 2.65 & 2.13 \\
\hline $6-1-4$ & 2.65 & 2.13 \\
\hline $6-1-5$ & 2.65 & 2.12 \\
\hline $6-1-6$ & 2.65 & 2.88 \\
\hline $6-1-7$ & 2.65 & 2.14 \\
\hline $6-1-8$ & 2.66 & 2.14 \\
\hline $6-1-9$ & 2.64 & 2.13 \\
\hline $6-1-10$ & 2.66 & 2.13 \\
\hline $6-1-11$ & 2.65 & 2.13 \\
\hline $6-1-12$ & 2.64 & 2.14 \\
\hline
\end{tabular}

Table 4-14: Combined particle density results for Rock Type 7, Air Cooled Slag, in g/cm 3

\begin{tabular}{|c|c|c|}
\hline \multicolumn{3}{|c|}{ Table 4-14: Combined Particle Density Results for Rock Type 7, Air Cooled Slag } \\
\hline $\begin{array}{c}\text { Sample } \\
\text { ID }\end{array}$ & Helium Pycnometer Results $\left(\mathrm{g} / \mathrm{cm}^{\wedge} 3\right)$ & Saturated Surface Dry Method $\left(\mathrm{g} / \mathrm{cm}^{\wedge} 3\right)$ \\
\hline $7-1$ & 2.76 & 2.19 \\
\hline $7-2$ & 2.86 & 2.22 \\
\hline $7-3$ & 2.95 & 2.14 \\
\hline $7-4$ & 2.75 & 2.08 \\
\hline $7-5$ & 2.71 & 2.27 \\
\hline $7-6$ & 2.86 & 2.19 \\
\hline $7-7$ & 2.77 & 2.07 \\
\hline $7-8$ & 2.77 & 2.26 \\
\hline
\end{tabular}




\section{Analysis}

Of the four methods evaluated for bulk density testing, the most accurate method was determined to be the Wax-Immersion method. This method works well since the wax coating seals off the external pores of the rock, and prevents water from infiltrating the pores and being absorbed into the rock sample. The Wax-Immersion method is also easily used on materials that are highly fractured or in multiple pieces, as well as ones that may fall apart easily.

However, it should be noted that with some rock types whose internal structure lacks significant surface pores or is highly impermeable the use of the Instantaneous Water Immersion method would be just as accurate. For example, the Jacobsville Sandstone was a highly permeable rock type and when conducting the Instantaneous Water Immersion trial it was difficult to obtain an accurate value for the suspended weight as the scale continued to record a higher weight as the water permeated the sample. These caused serious issues with an accurate determination of bulk density for the sandstone. However, when looking at the Granite and Kona Dolomite samples both of which had a far lower porosity and permeability the values for the Wax Immersion method and the Instantaneous Water Immersion method were almost identical.

When inspecting Table 4-1 and comparing the Water Immersion and Wax Immersion columns, it can be seen that in general the two bulk densities are usually off by about 0.03 $\mathrm{g} / \mathrm{cm}^{3}$. In other more competent rock types such as the Granites and some of the Various Carbonates section, the two values match. This is due to those low permeability and porosity values and the lack of any surface pores. In almost every rock type tested, the Water Immersion method resulted in a density that was lower than the actual bulk density value due to the inaccurate suspended weight measurement from water infiltrating the rock cores.

The main drawback to the Wax-Shrink wrap Immersion method is the difficulty in removing all of the trapped air that is trapped between the shrink wrap and the surface of the rock while wrapping them in shrink wrap. On materials that lack deep surface pores, such as the granite or sandstones, it was possible to get a relatively secure wrap. However, on the air and water cooled slag samples the deeper and larger the surface pores were, the higher the overall error was, in calculating the bulk density of the sample. This was due in part to it not being possible to wrap the entire interior space of the pores with the plastic. This added to 
the calculated volume of the sample, and resulted in a lower calculated bulk density of the sample.

The Caliper method resulted in very accurate results for some of the cores that did not contain large surface pores. For the blast slag samples, which did have extremely large pores, this difference was very apparent. In other more massive rock types, such as the granite, the results were very precise and normally within $0.01 \mathrm{~g} / \mathrm{cm}^{3}$ of each other.

Consequently, in the remaining discussion, the bulk density values discussed are from the Wax-Immersion method.

In terms of the particle density, the SSD clearly fails to accurately represent the particle density of the materials in many cases. The clear example of this is found with the two blast slag samples. Here, the difference between the two values can be upward of $0.5 \mathrm{~g} / \mathrm{cm}^{3}$, which is a very significant difference. Part of this issue is due to the surface pores of the rock samples, and how this method actually works. The main assumption of the SSD method is that the while the surface pores still contain water, the surface of the sample is dry. When the surface pores reach a diameter larger than about $5 \mathrm{~mm}$ the capillary action of the water molecules can no longer hold the water in the pores and it drains away.

As many of these samples contain very large, deep, and connected pores much of the water that is assumed to still be present in the rock sample is no longer trapped in the pores. These results in the calculated saturated weight being lower than it should be. Evidence that this is the issue is that other rock types, such as the granite did not have a significant issue with the SSD calculation. The granite samples results for the two methods as seen in Table 4-2 are almost identical. This data provides evidence that in cases of highly impermeable dense rock, the SSD method will work. However the larger the pores of the sample, the less accurate this method becomes.

The following graphs in this section illustrate this issue with the SSD method. The raw data behind these graphs are located in Appendix $\mathrm{H}$ of this report. Each graph is the result of testing over a twenty four hour period. During this time the core samples were completely submerged in water and every one to four hours removed and weighed to see how much water weight had been added to the sample.

Ideally each sample should reach a point where the weight of the sample is no longer increasing. According to the SSD method, this will happen within a twenty four long period, 
however as shown in the following graphs, in many cases this is not correct. For some materials the samples actually continue to gain weight during the entire process.

Also shown on the graphs is the red line which indicated the actual porosity of the material. This was calculated using the particle density from the Helium Pycnometer and the bulk density from the Wax Immersion method.

The green line on the graphs marks the indicated porosity. This porosity marks what the porosity of the sample appears to be based on the results of the SSD test.

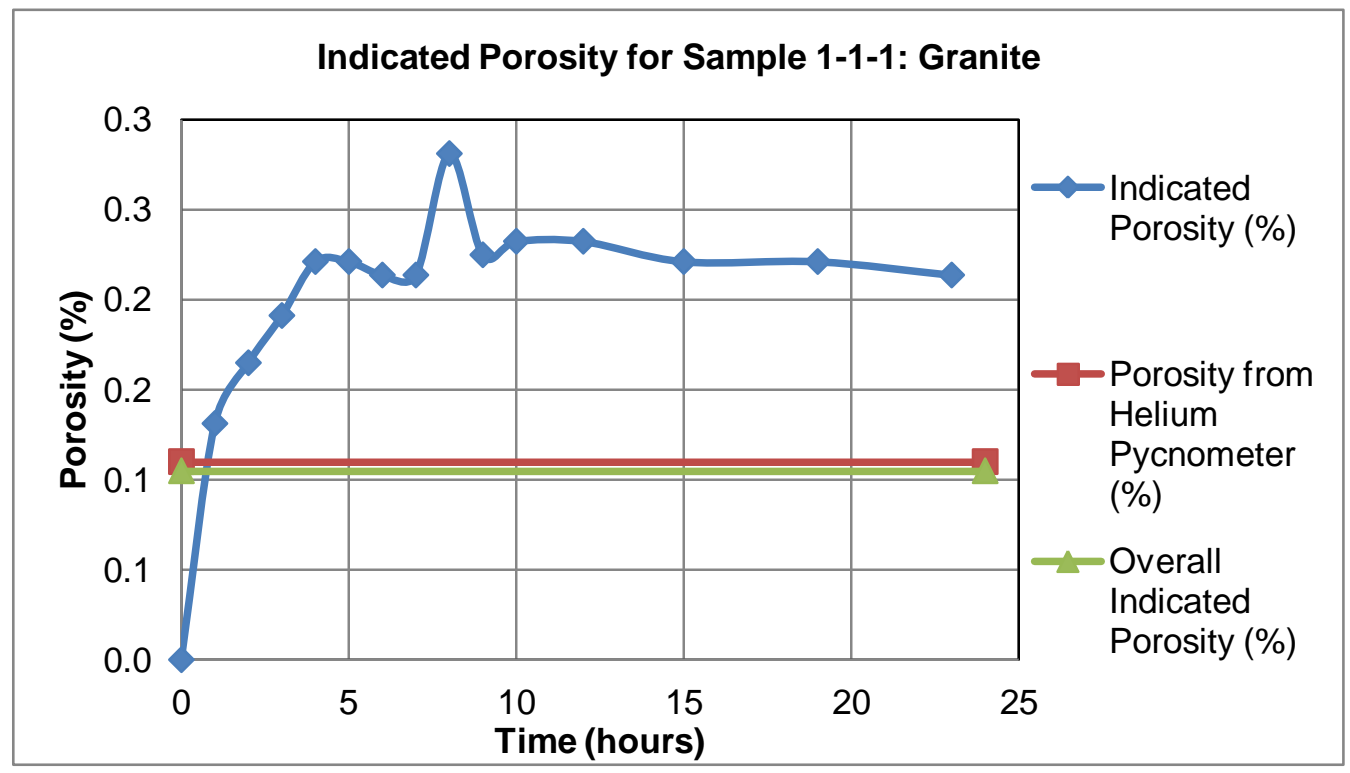

Figure 5-1: Indicated Porosity Graph for sample number 1-1-1, Granite 


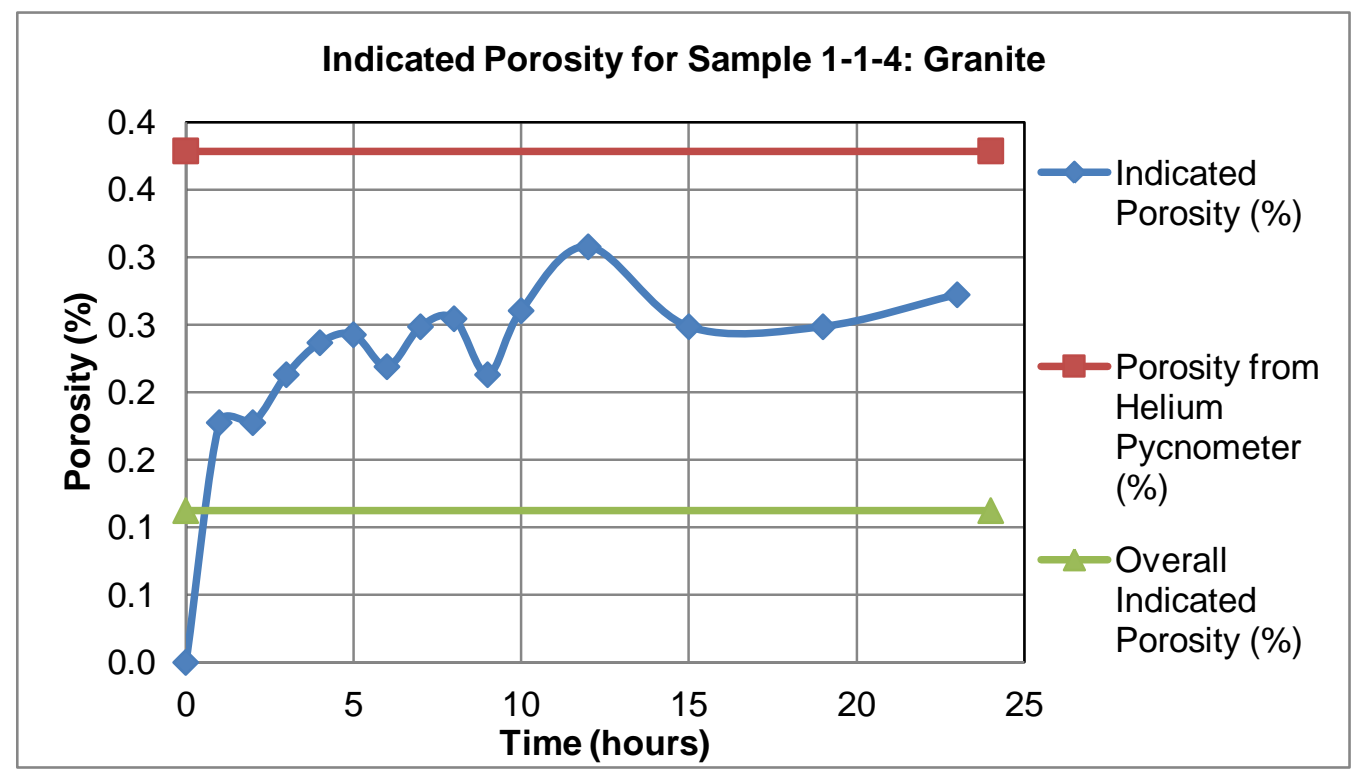

Figure 5-2: Indicated Porosity Graph for sample number 1-1-4, Granite

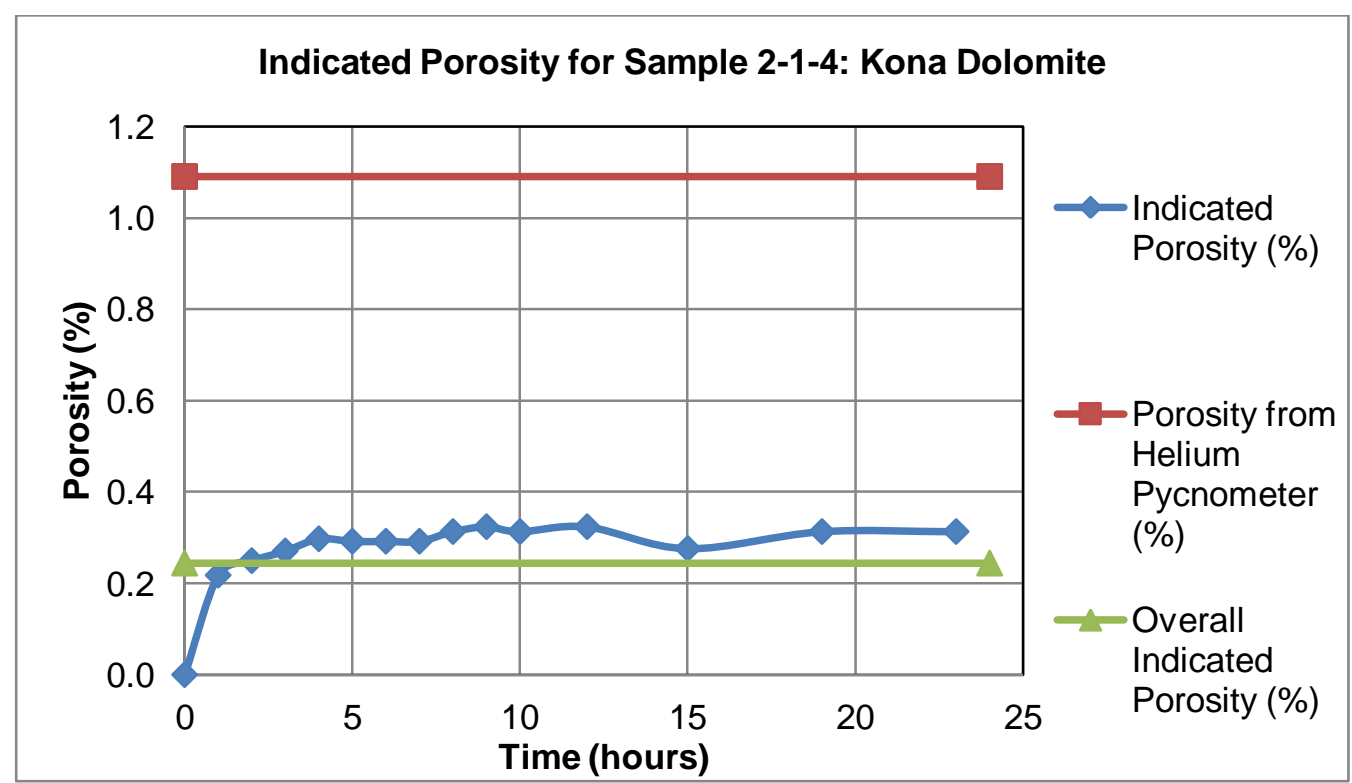

Figure 5-3: Indicated Porosity Graph for sample number 2-1-4, Kona Dolomite 


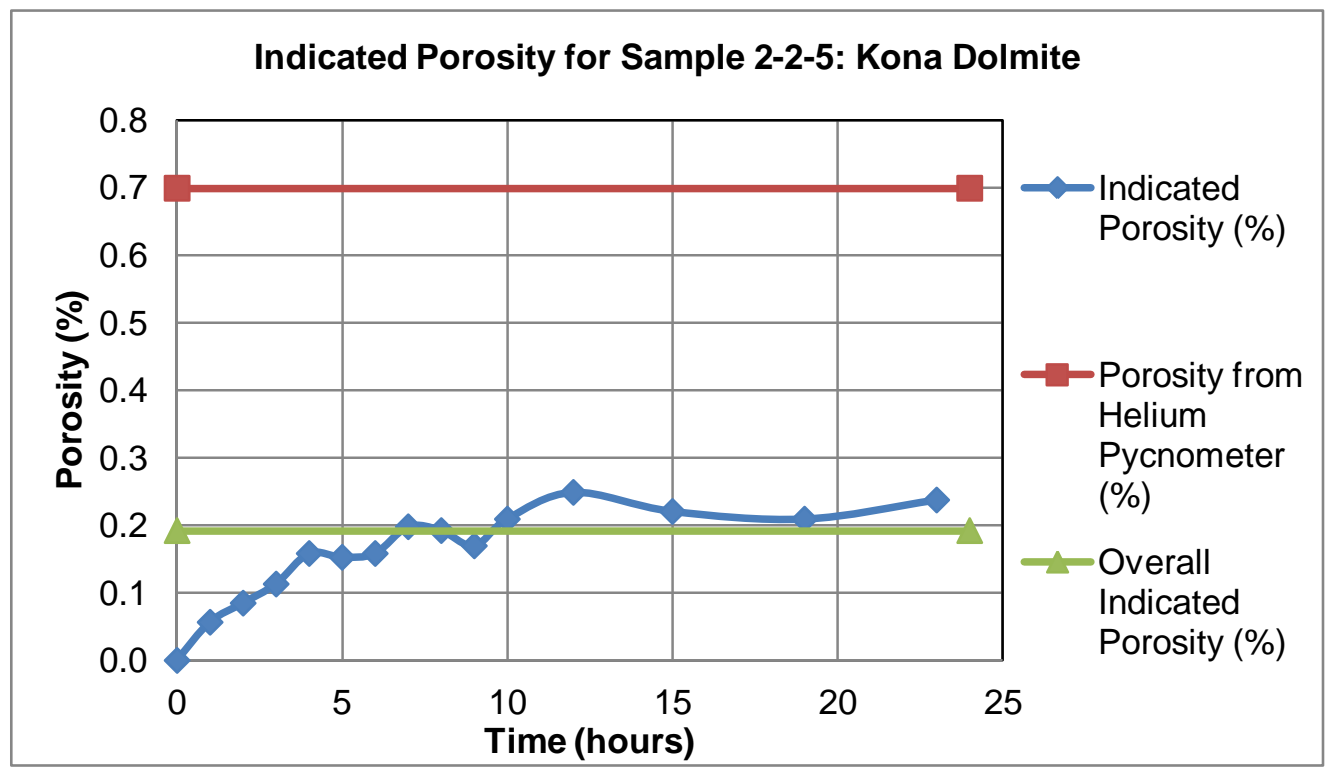

Figure 5-4: Indicated Porosity Graph for sample number 2-2-5, Kona Dolomite

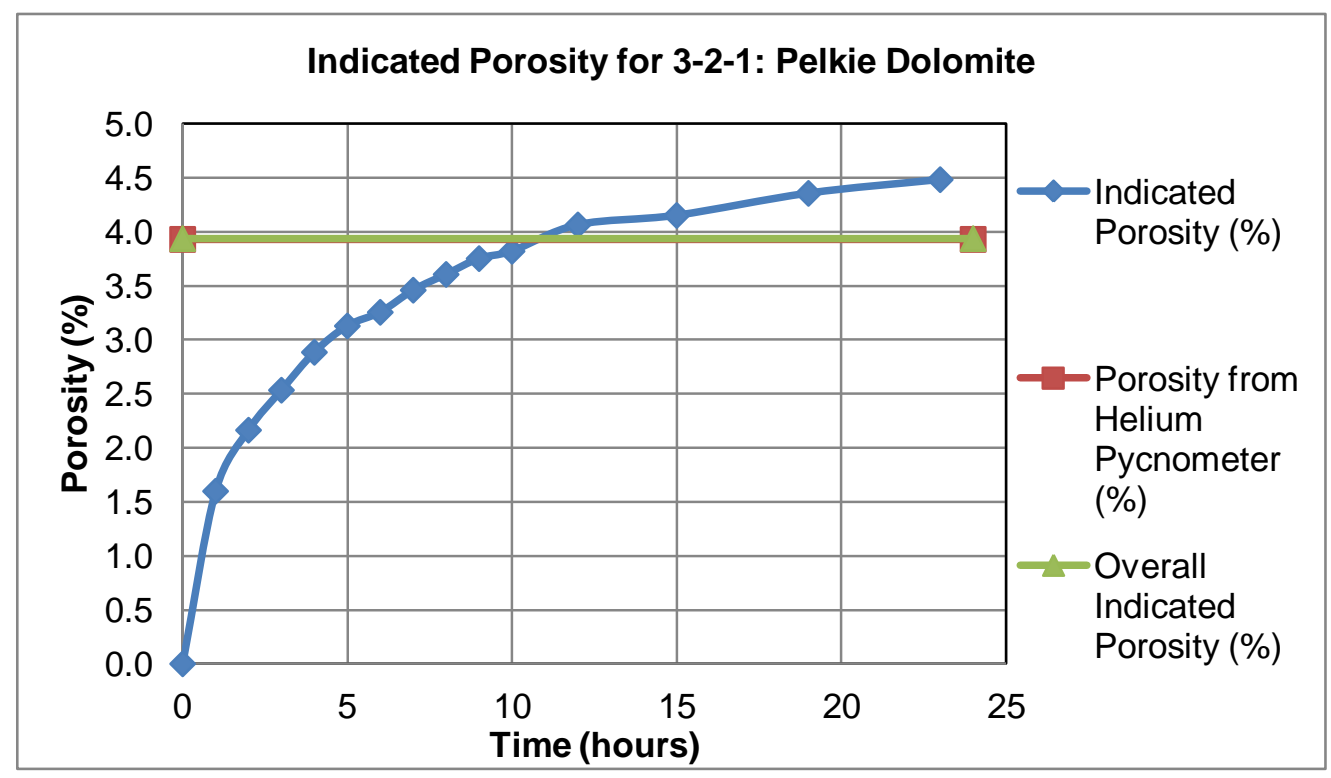

Figure 5-5: Indicated Porosity Graph for sample number 3-2-1, Pelkie Dolomite 


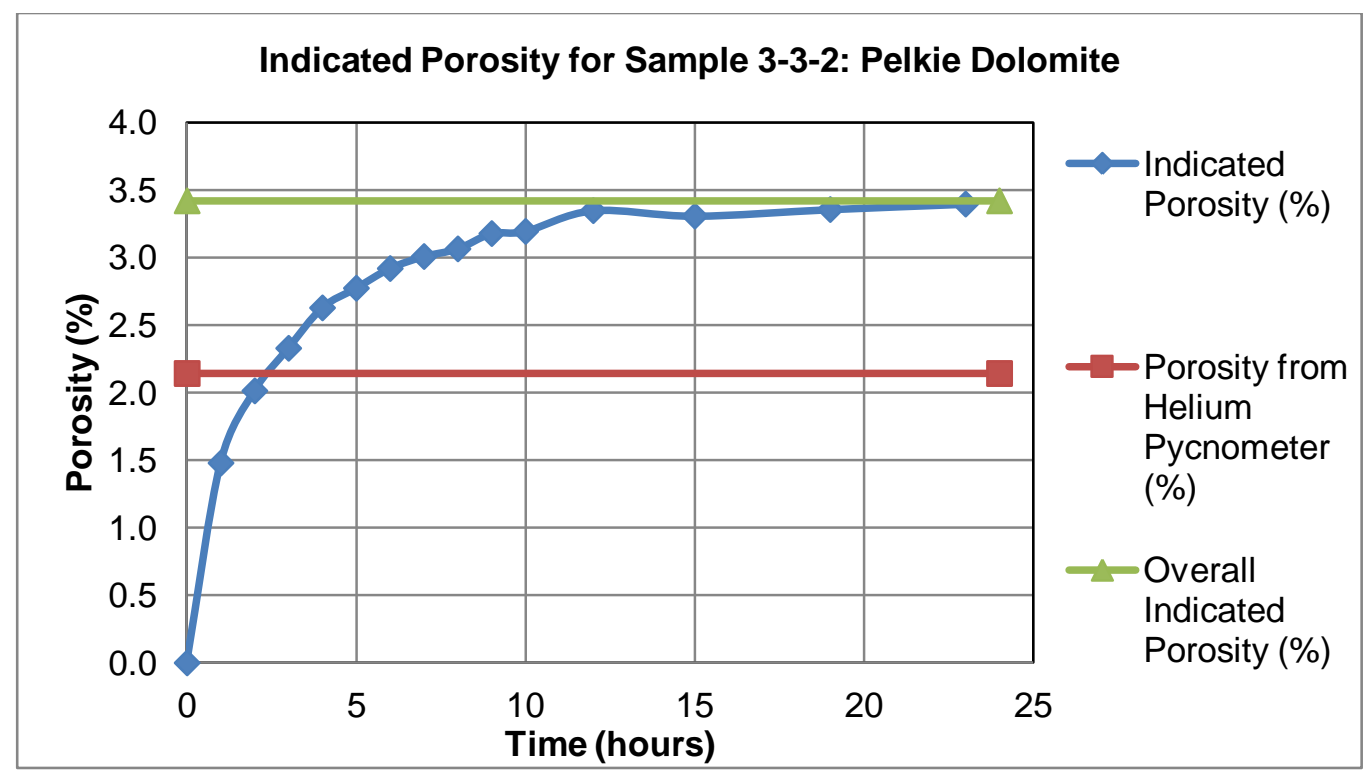

Figure 5-6: Indicated Porosity Graph for sample number 3-3-2, Pelkie Dolomite

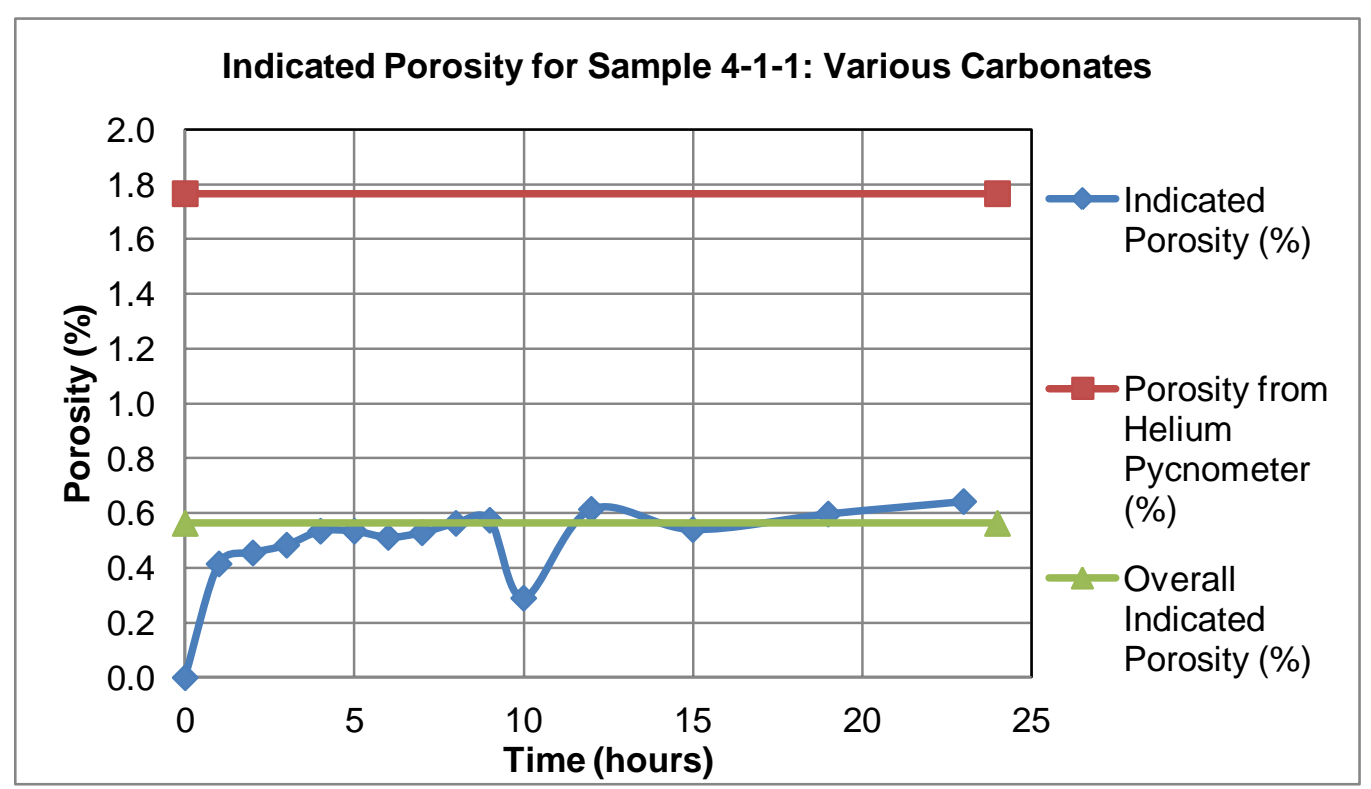

Figure 5-7: Indicated Porosity Graph for sample number 4-1-1, Various Carbonate 


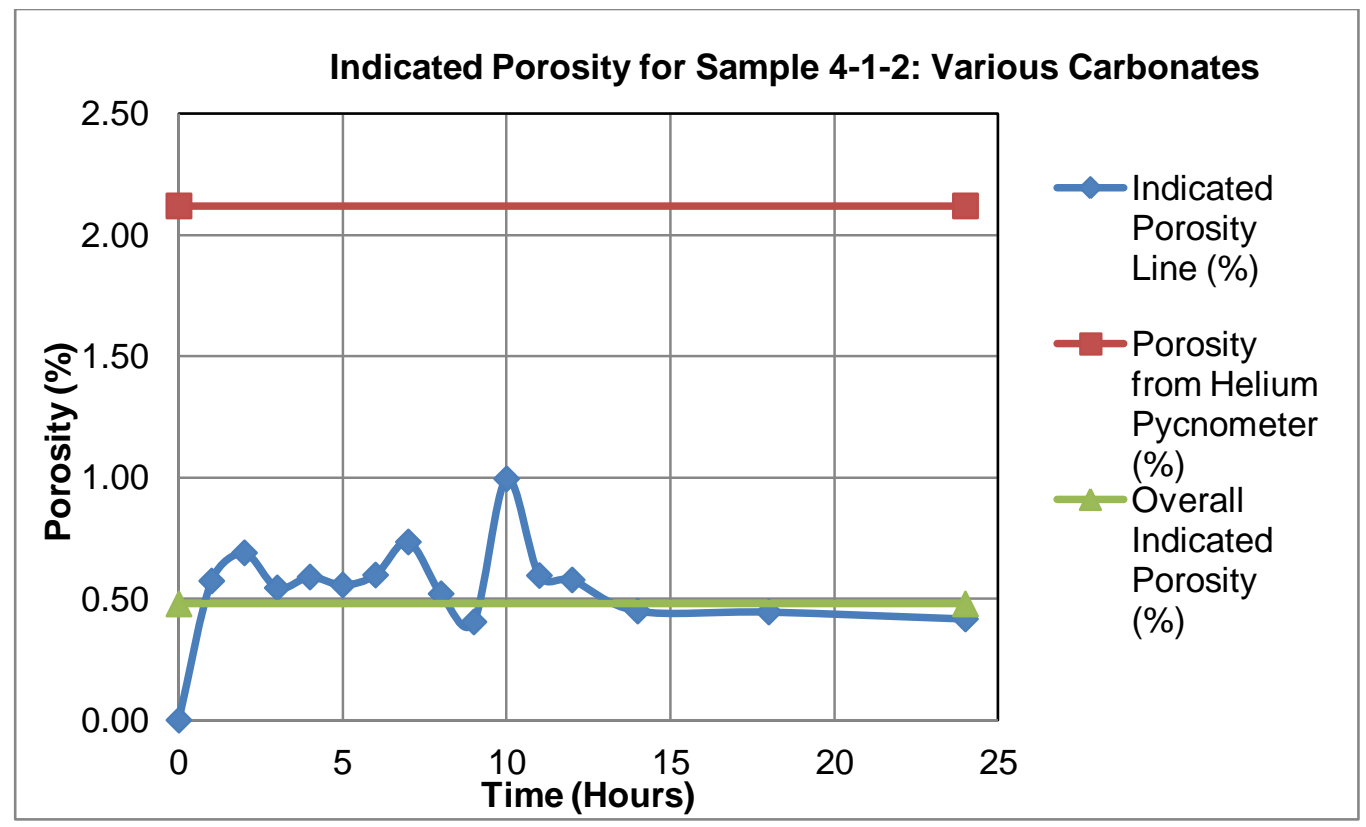

Figure 5-8: Indicated Porosity Graph for sample number 4-1-2, Various Carbonates

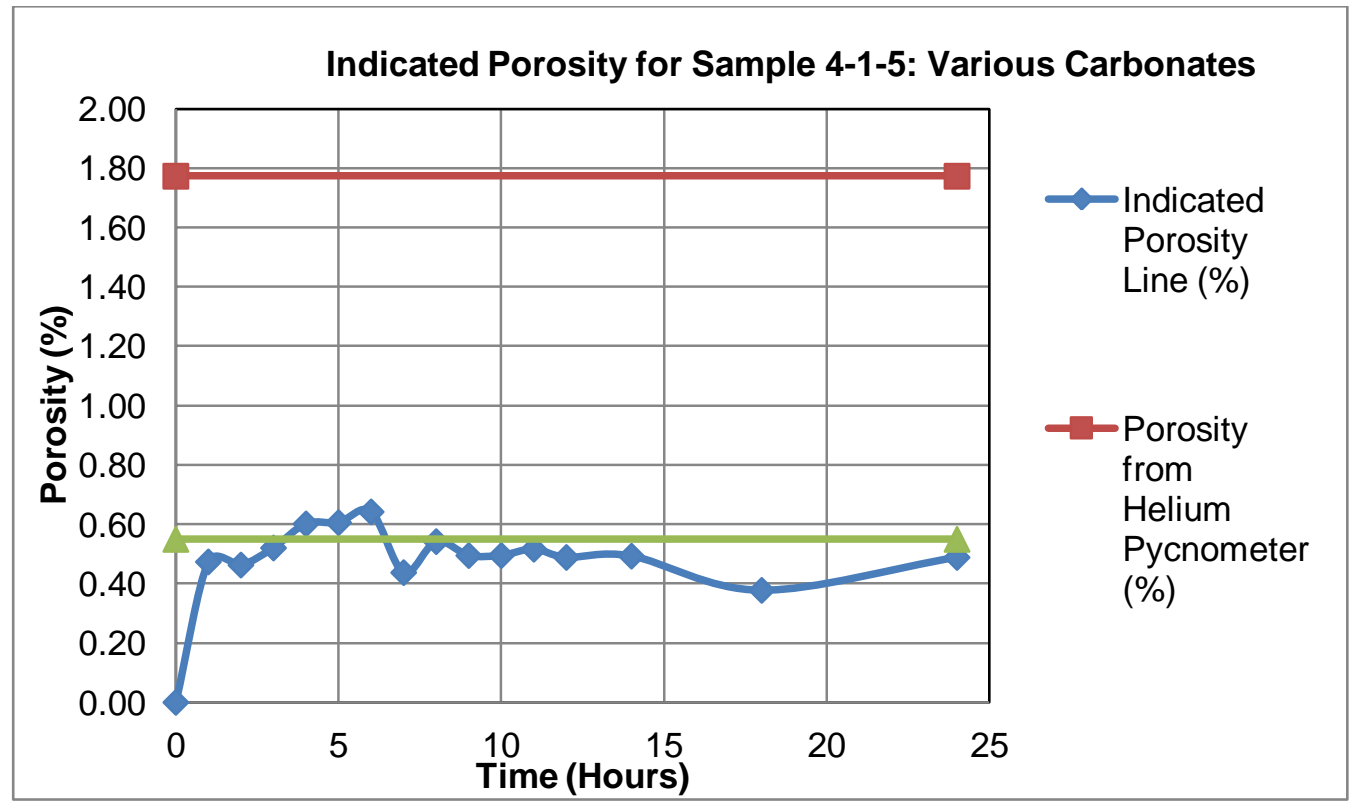

Figure 5-9: Indicated Porosity Graph for sample number 4-1-5, Various Carbonates 


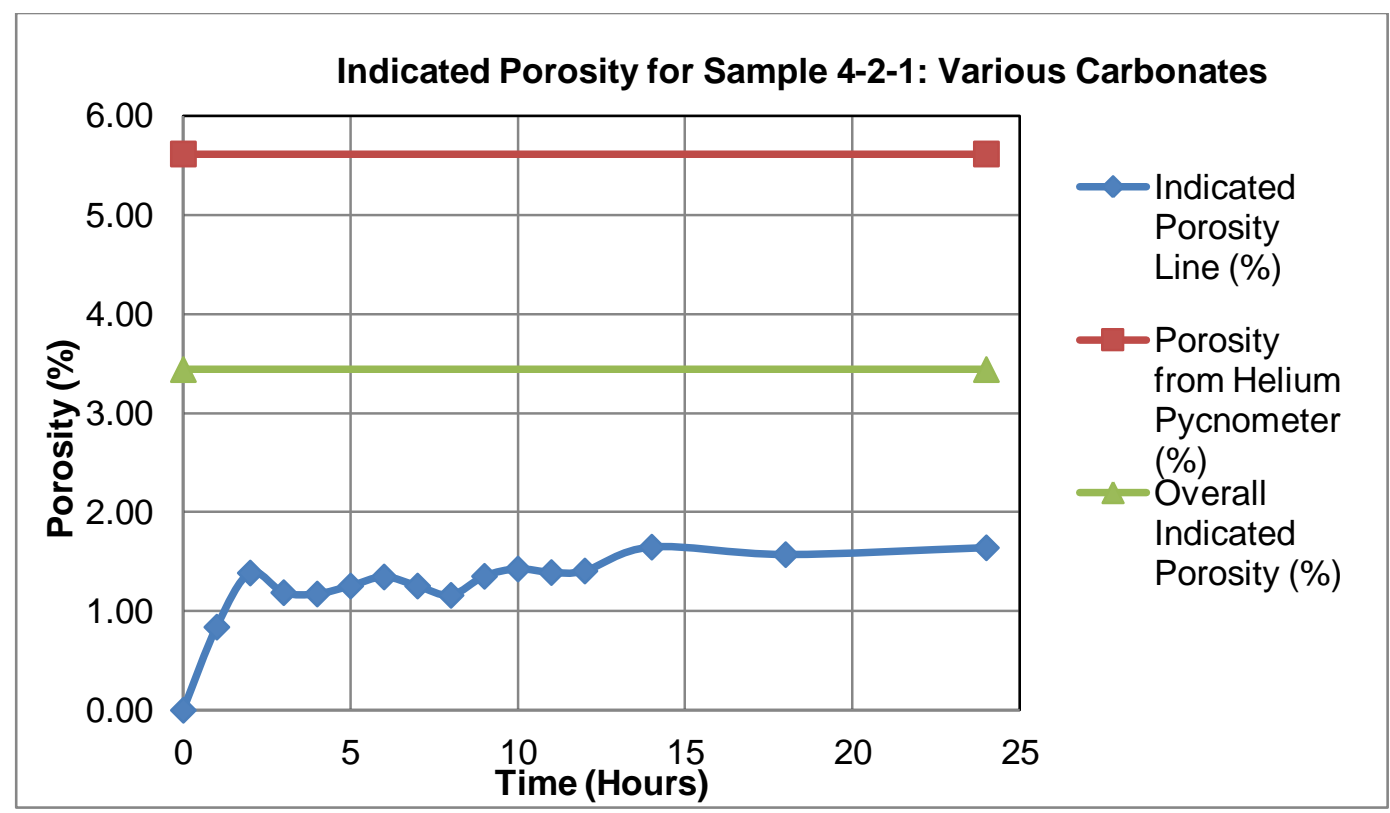

Figure 5-10: Indicated Porosity Graph for sample number 4-2-1, Various Carbonates

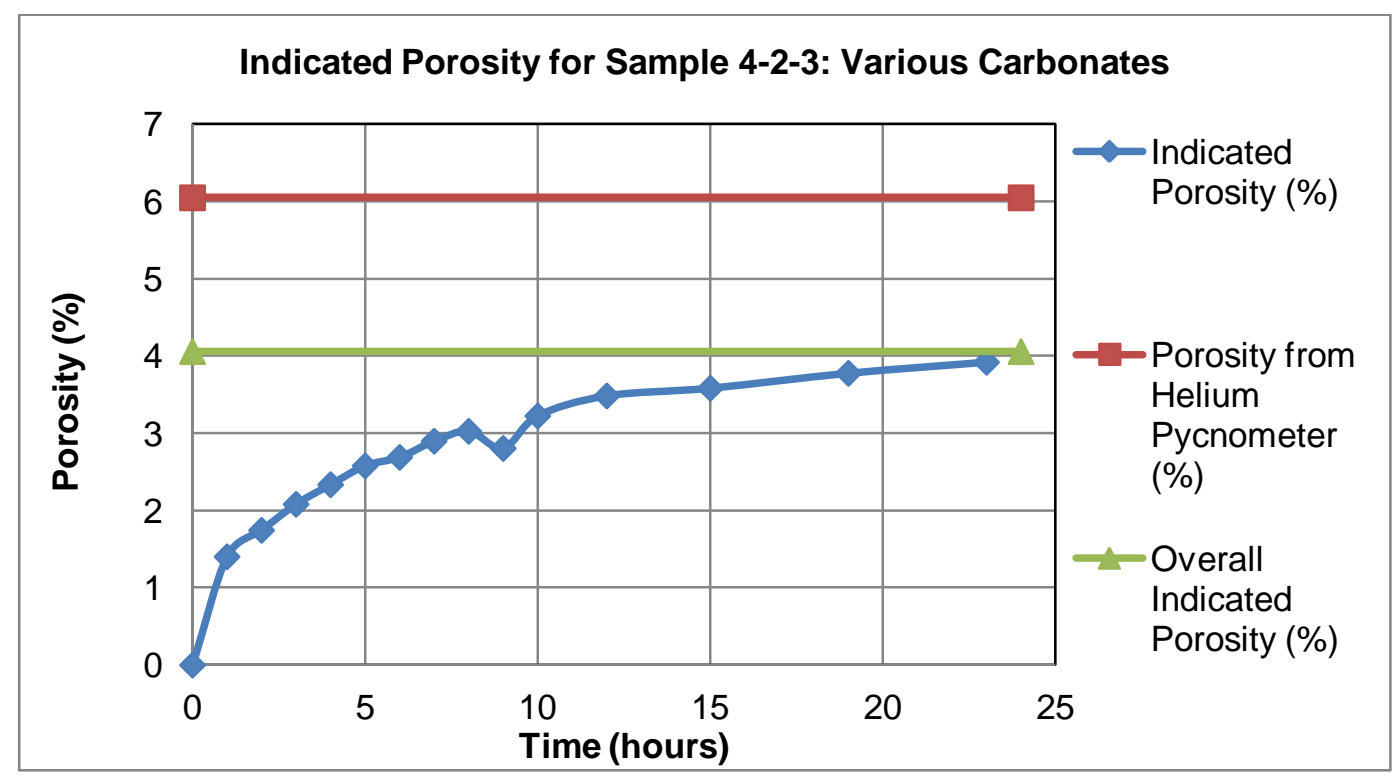

Figure 5-11: Indicated Porosity Graph for sample number 4-2-3, Various Carbonat 


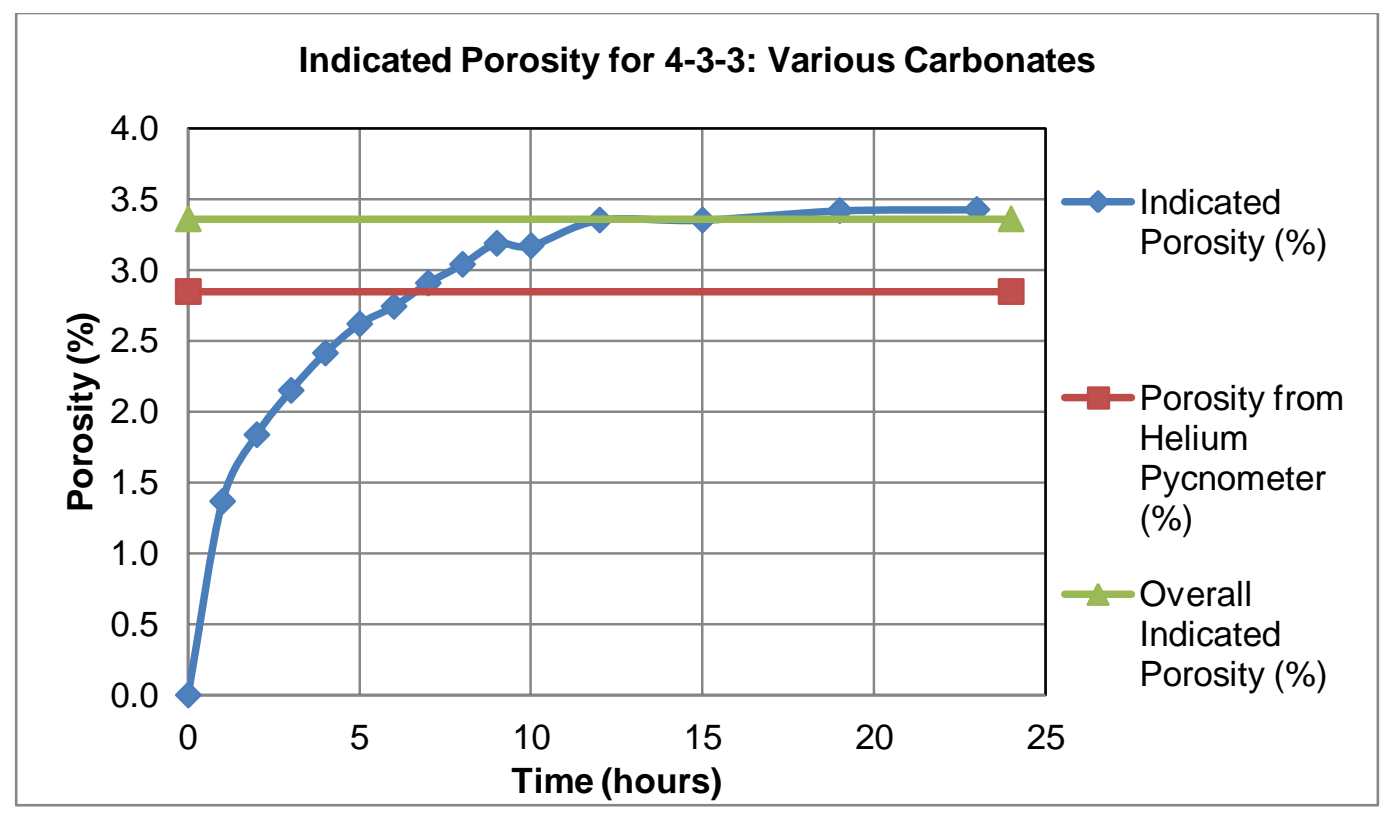

Figure 5-12: Indicated Porosity Graph for sample number 4-3-3, Various Carbonates

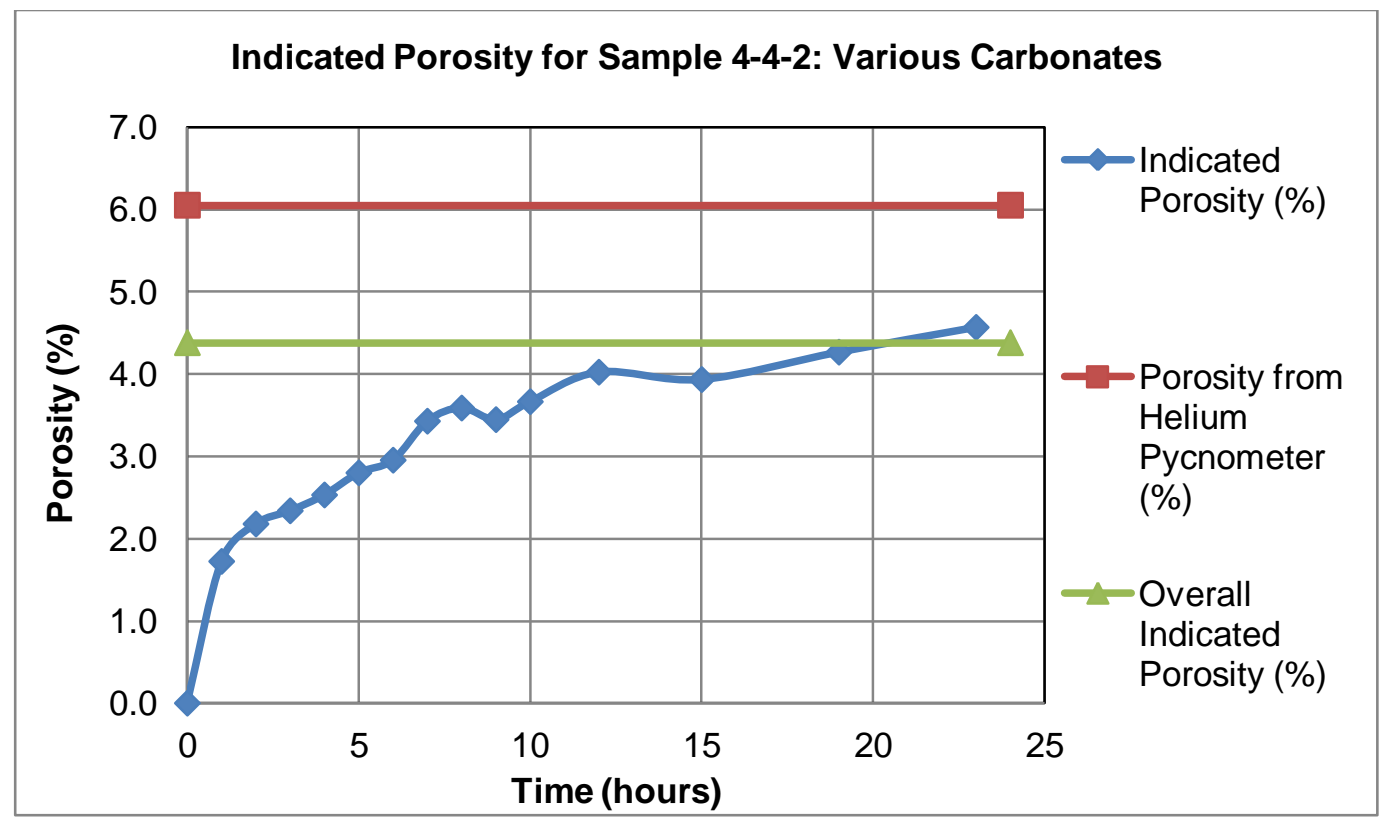

Figure 5-13: Indicated Porosity Graph for sample number 4-4-2, Various Carbonates 


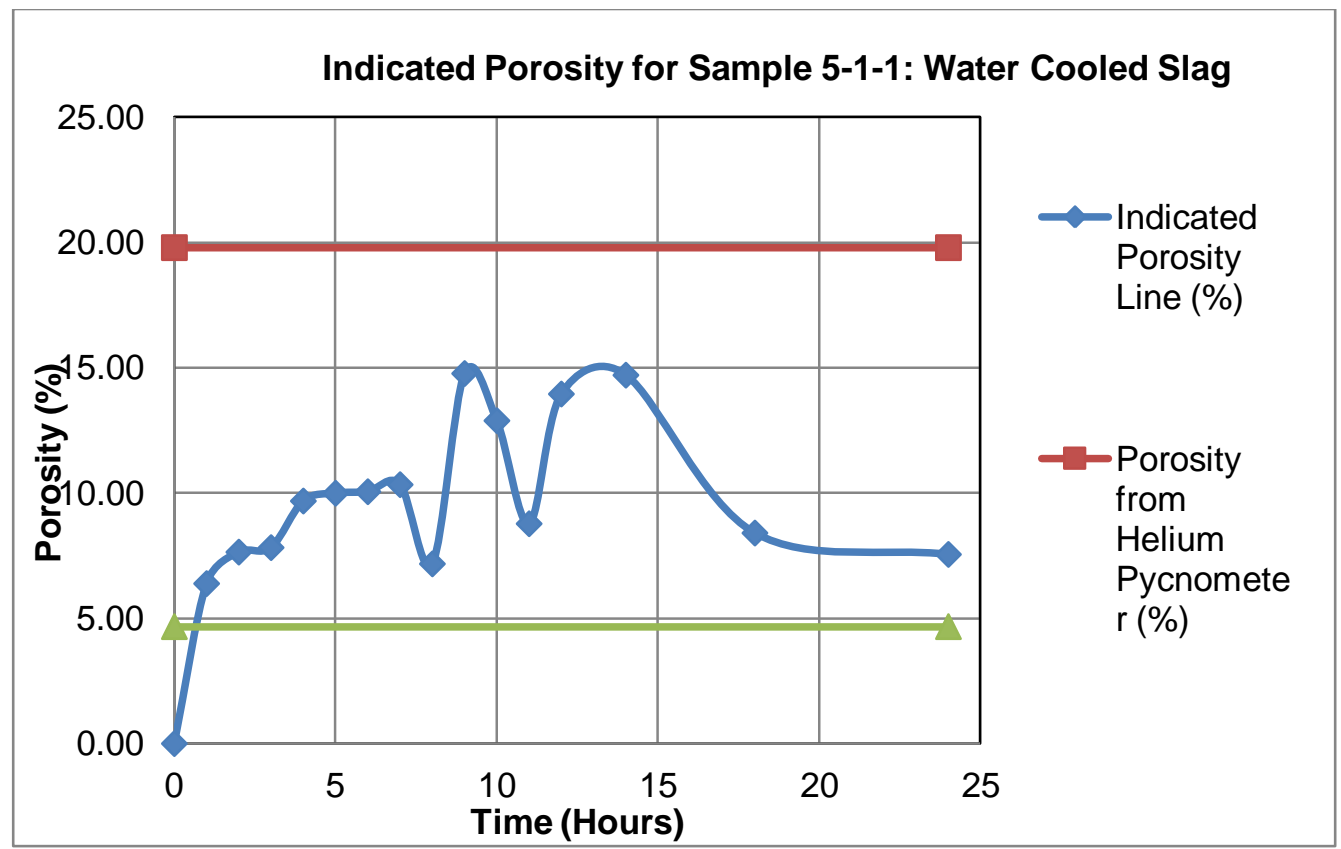

Figure Figure 5-14: Indicated Porosity Graph for sample number 5-1-1, Water Cooled Slag

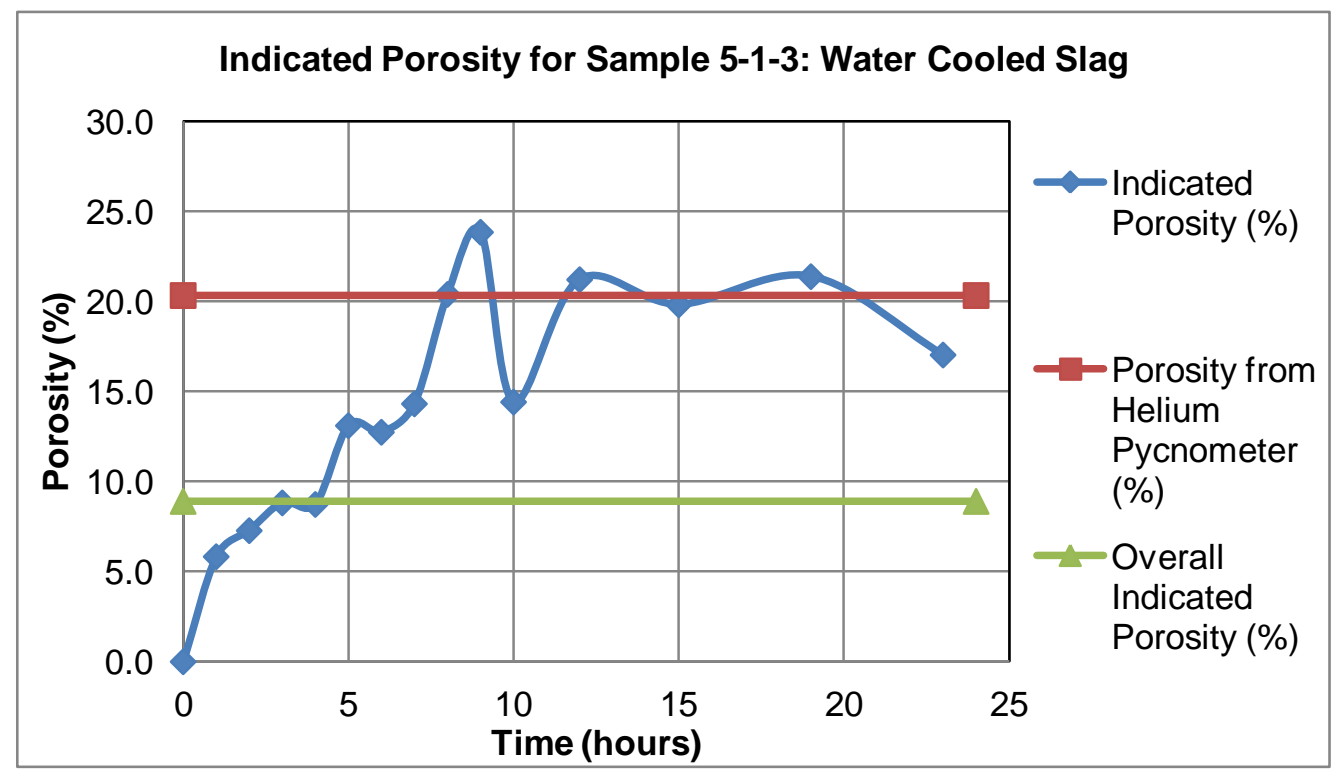

Figure 5-15: Indicated Porosity Graph for sample number 5-1-3, Water Cooled Slag 


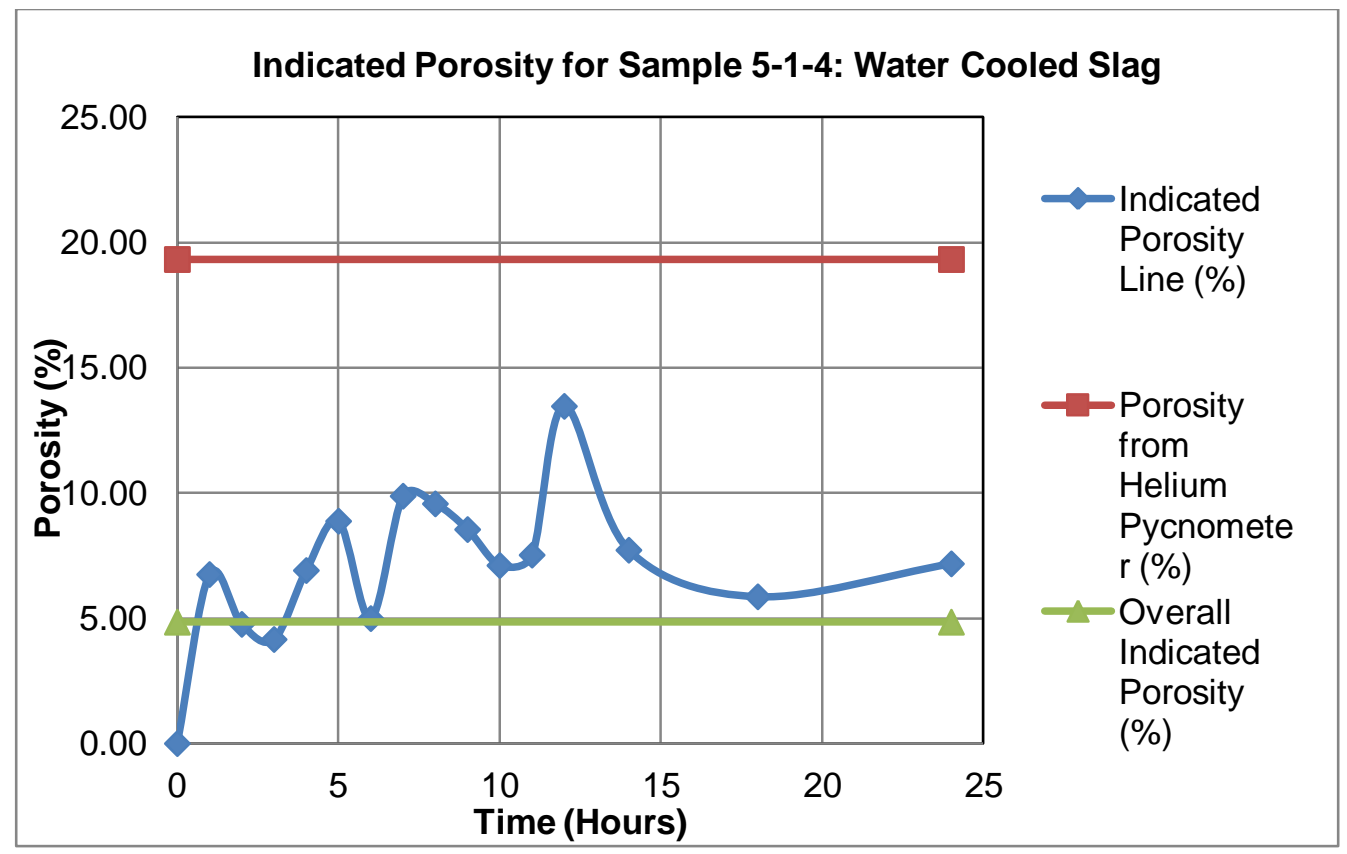

Figure 5-16: Indicated Porosity Graph for sample number 5-1-4, Water Cooled Slag

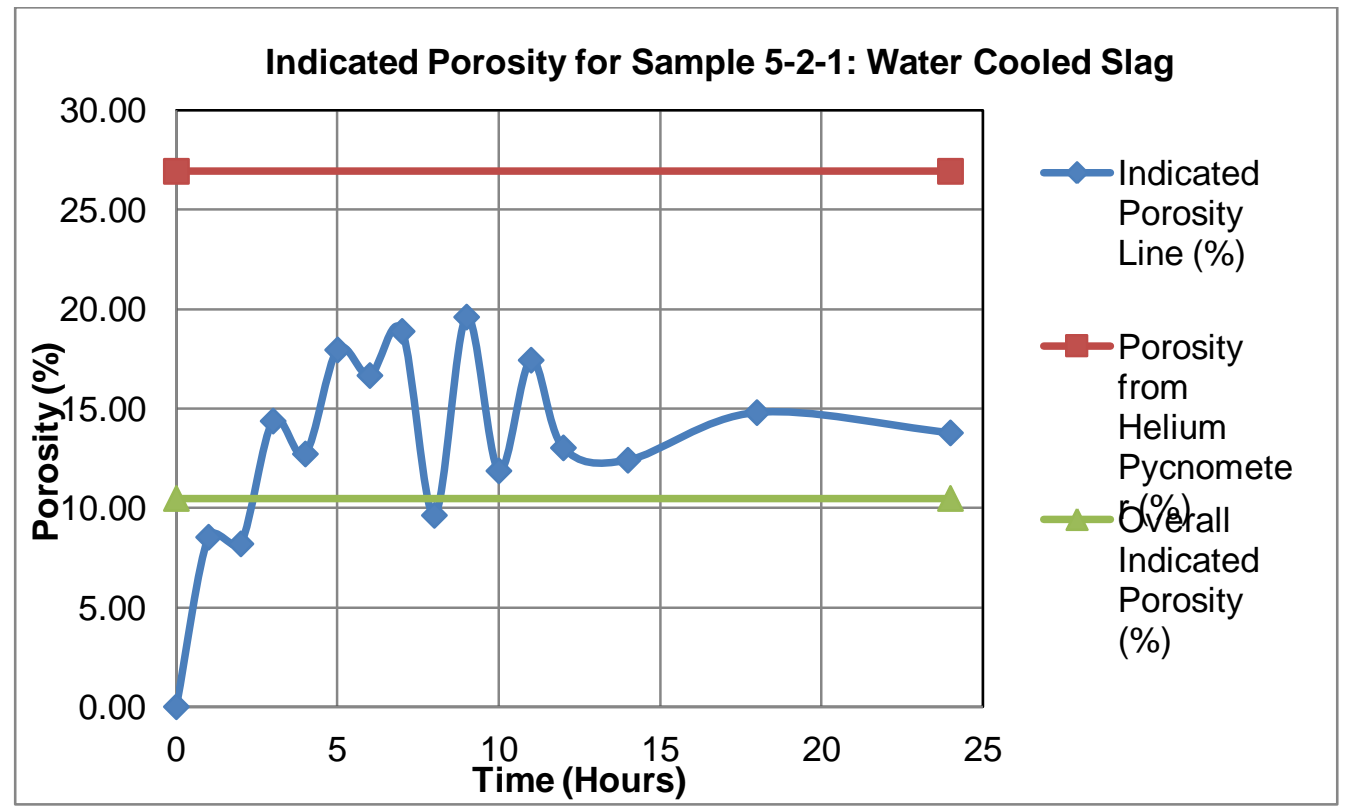

Figure 5-17: Indicated Porosity Graph for sample number 5-2-1, Water Cooled Slag 


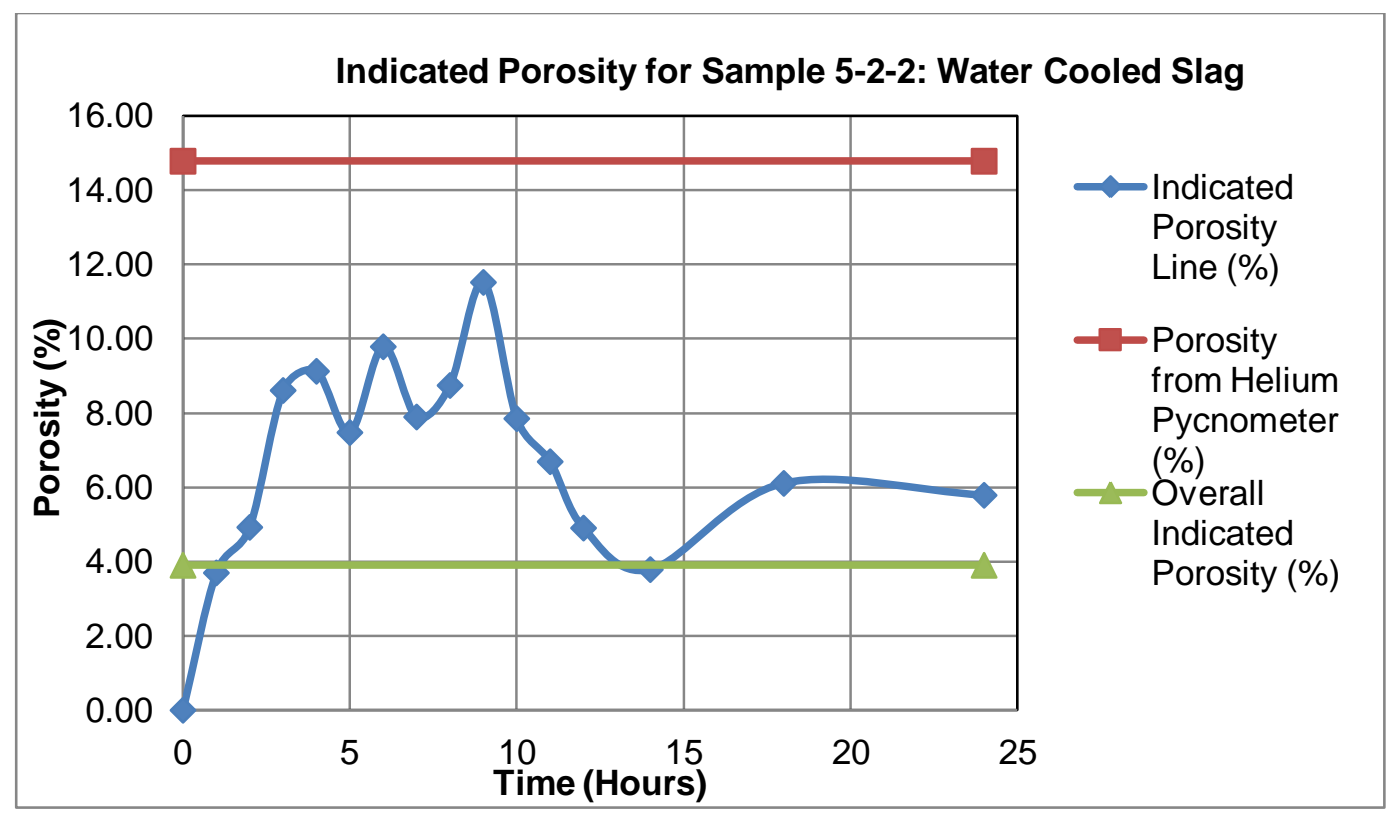

Figure 5-18: Indicated Porosity Graph for sample number 5-2-2, Water Cooled Slag

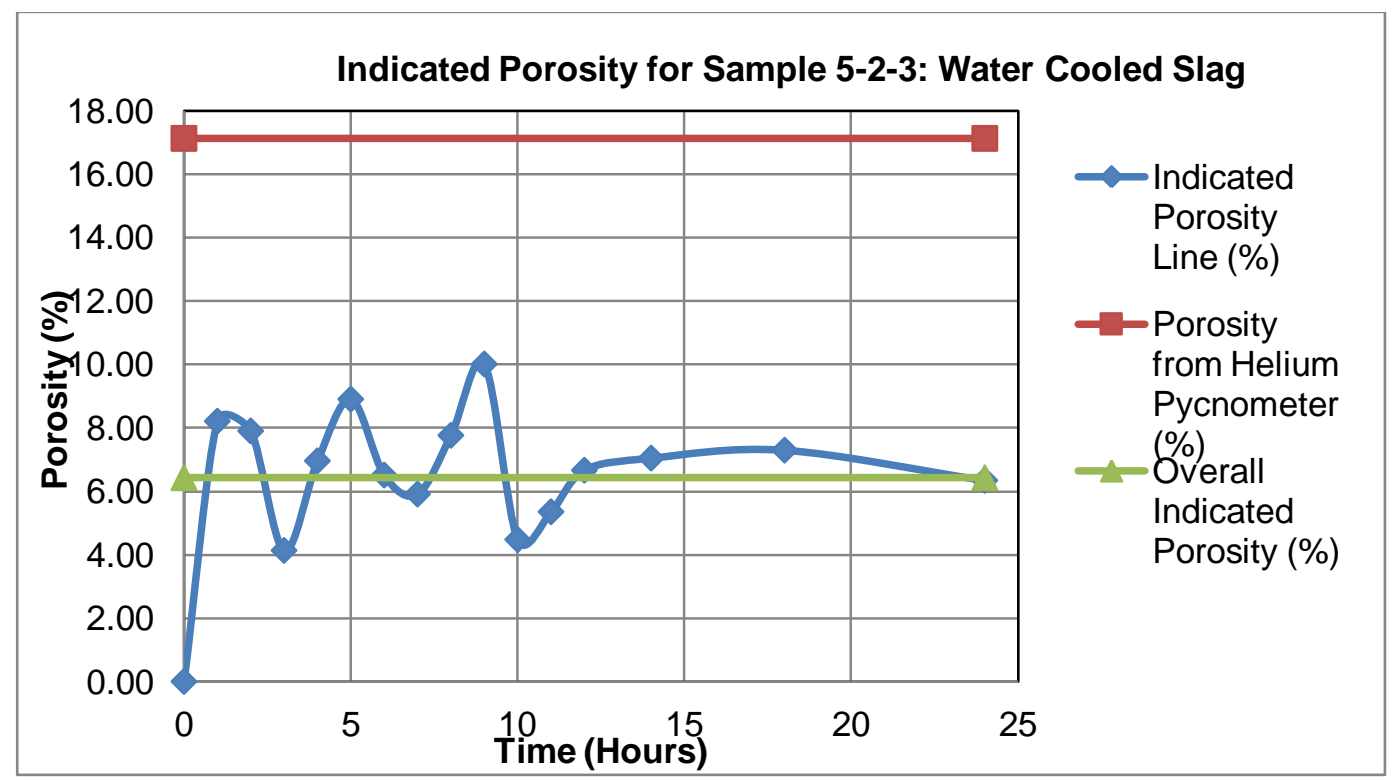

Figure 5-19: Indicated Porosity Graph for sample number 5-2-3, Water Cooled Slag 


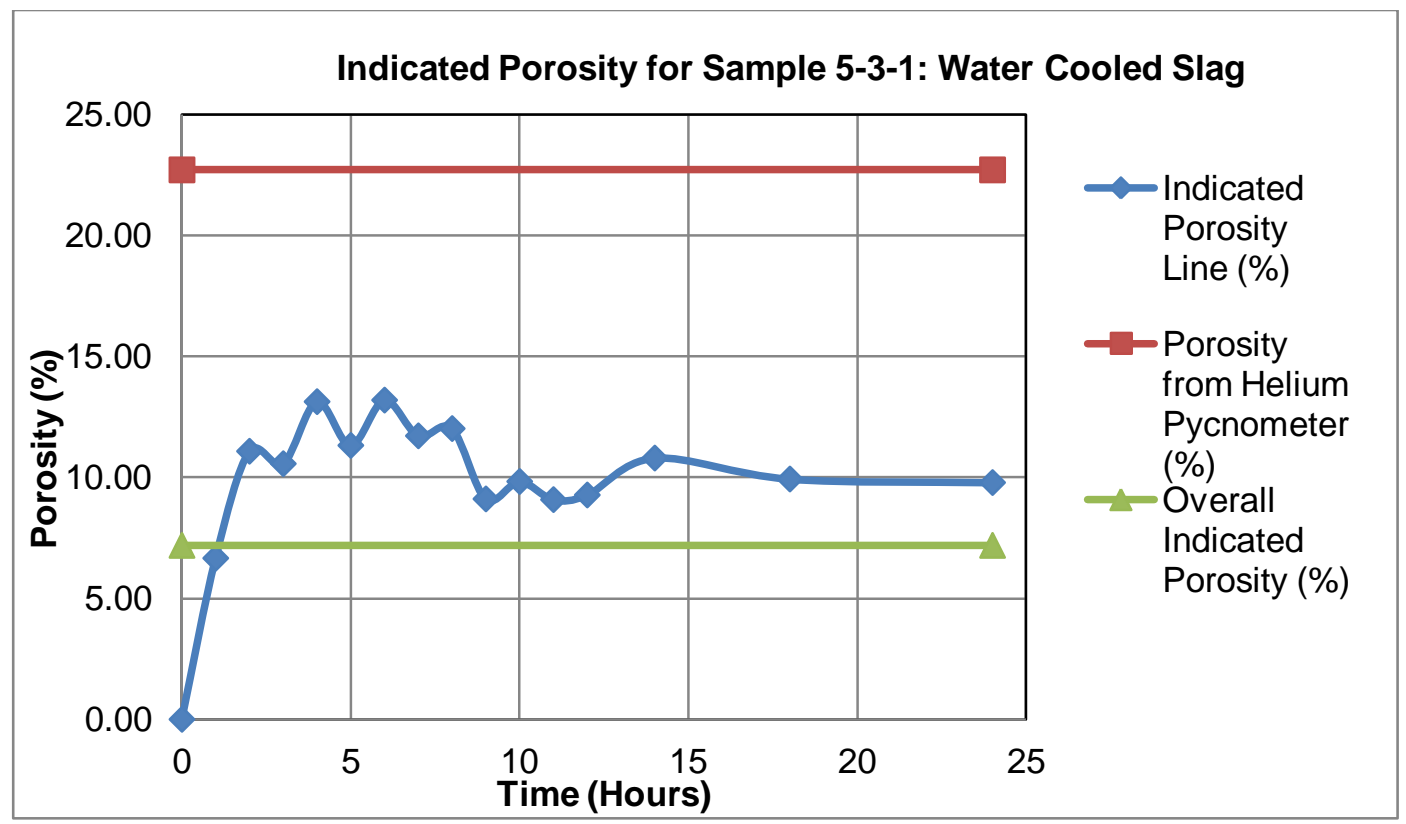

Figure 5-20: Indicated Porosity Graph for sample number 5-3-1, Water Cooled Slag

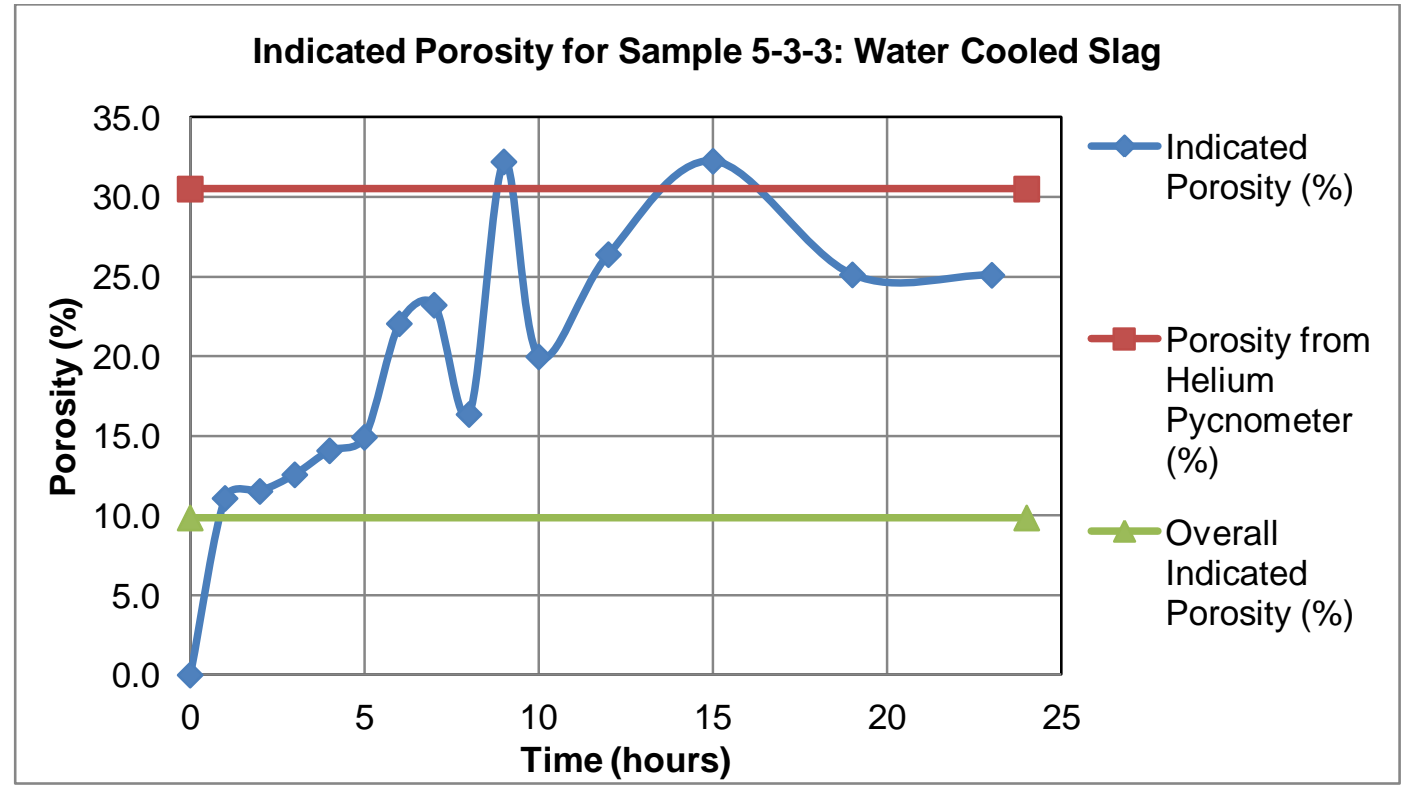

Figure 5-21: Indicated Porosity Graph for sample number 5-3-3, Water Cooled Slag 


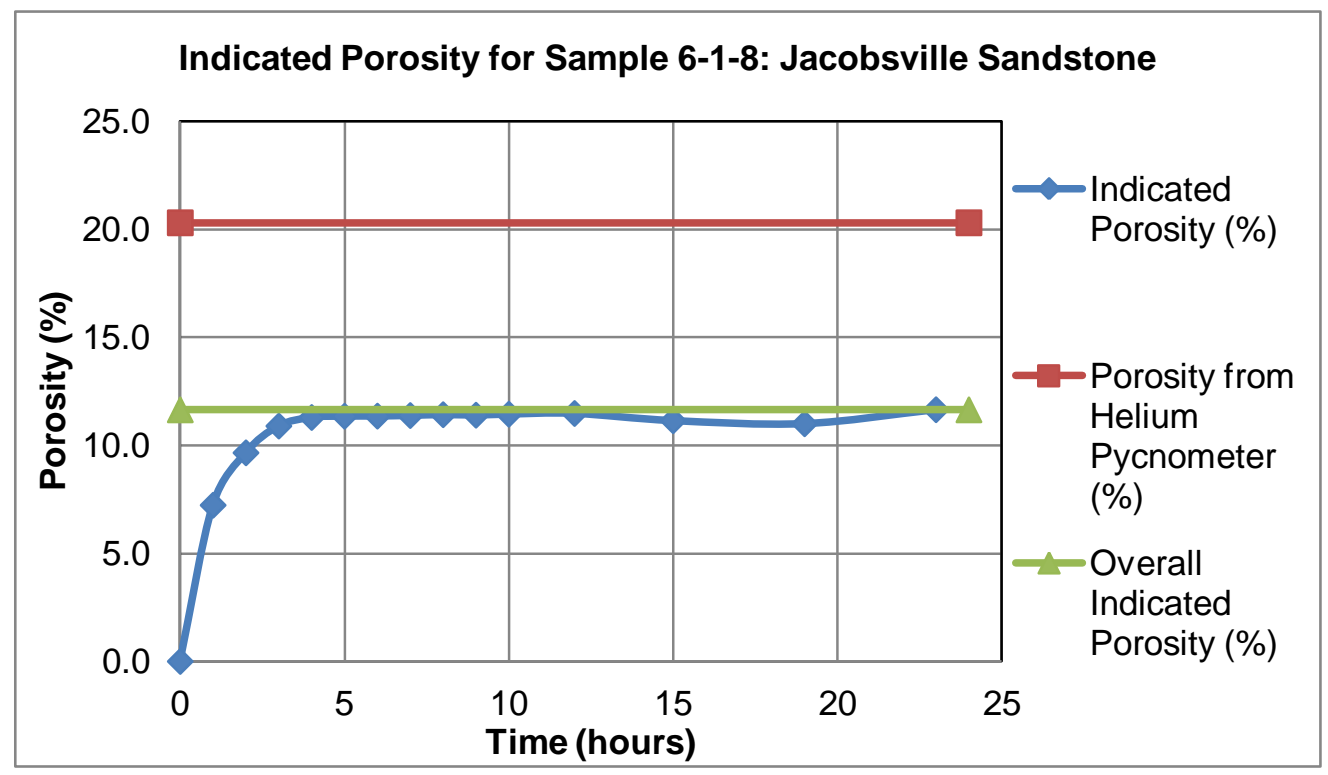

Figure 5-22: Indicated Porosity Graph for sample number 6-1-8, Jacobsville Sandstone

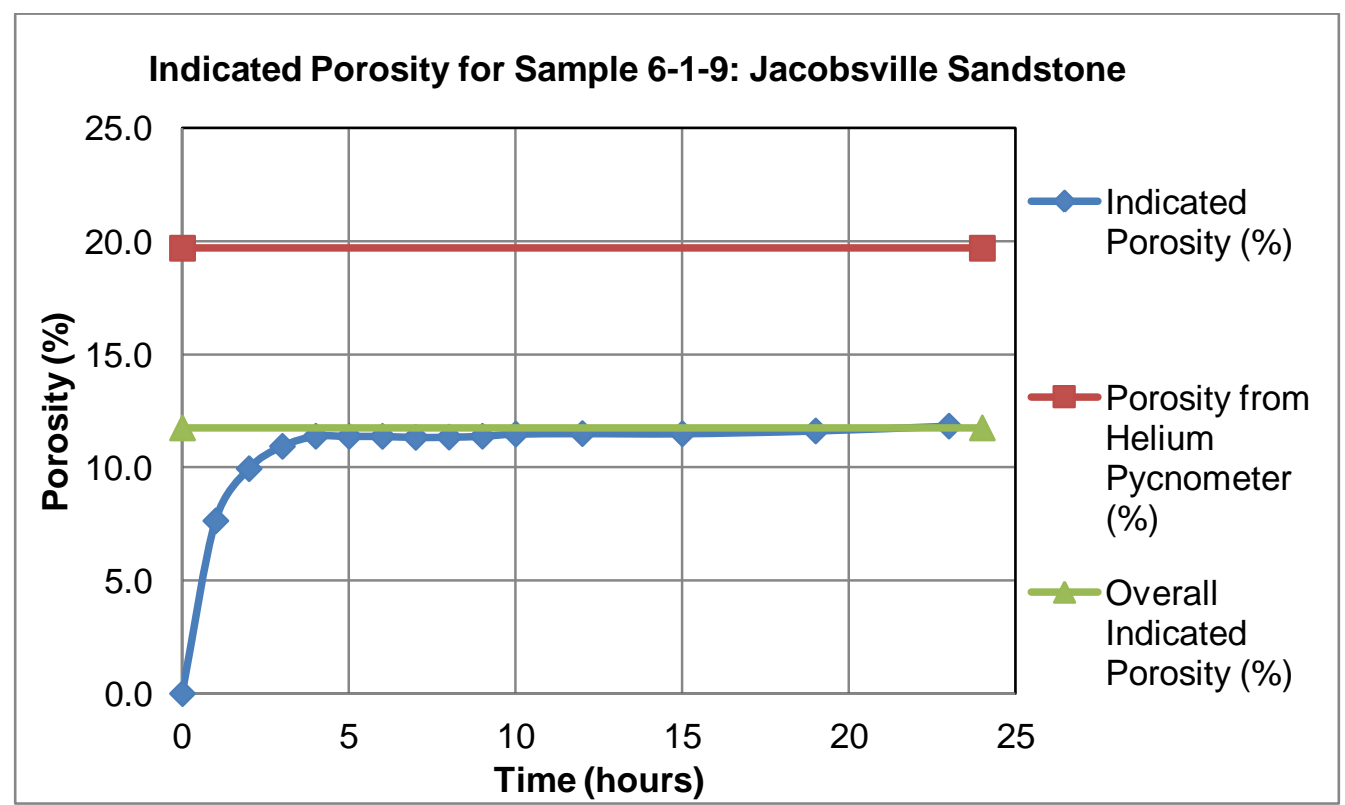

Figure 5-23: Indicated Porosity Graph for sample number 6-1-9, Jacobsville Sandstone 


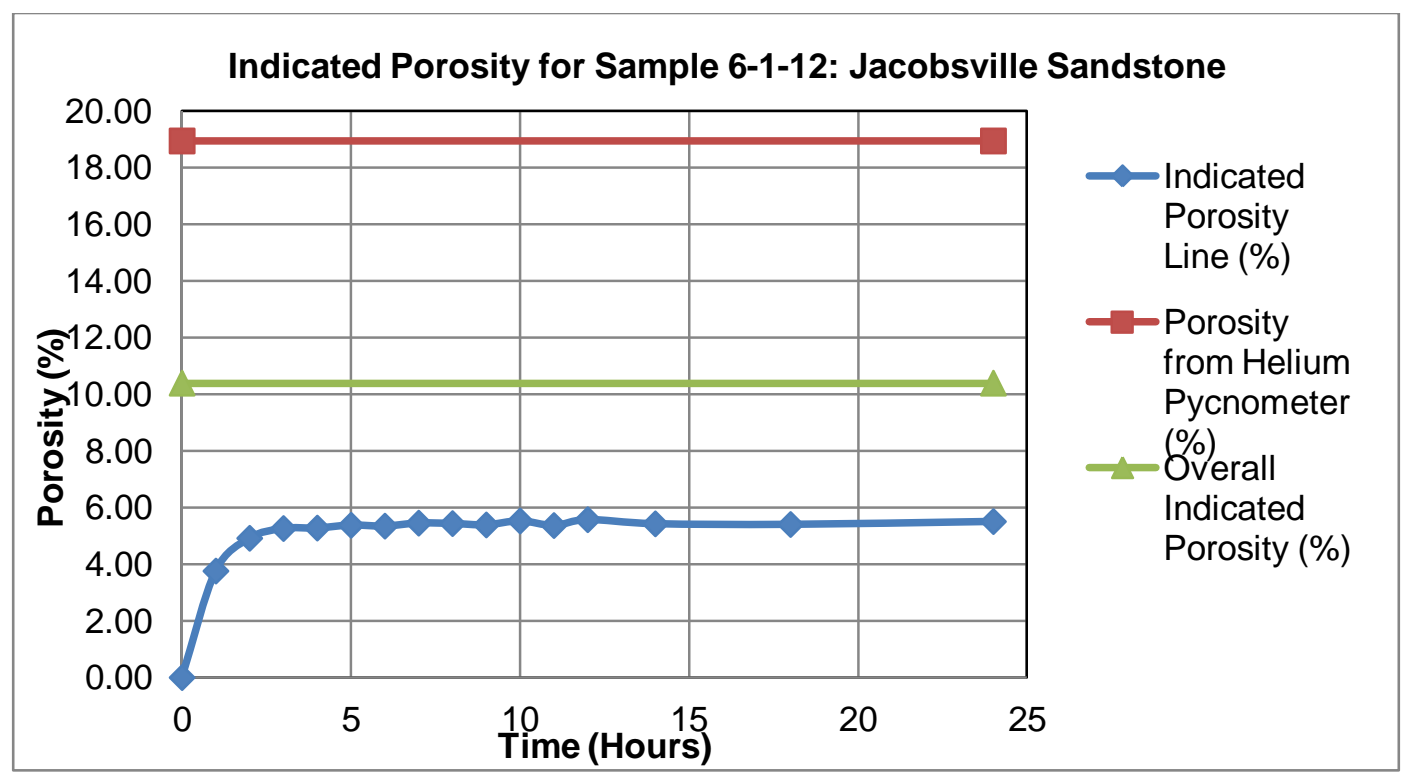

Figure 5-24: Indicated Porosity Graph for sample number 6-1-12, Jacobsville Sandstone

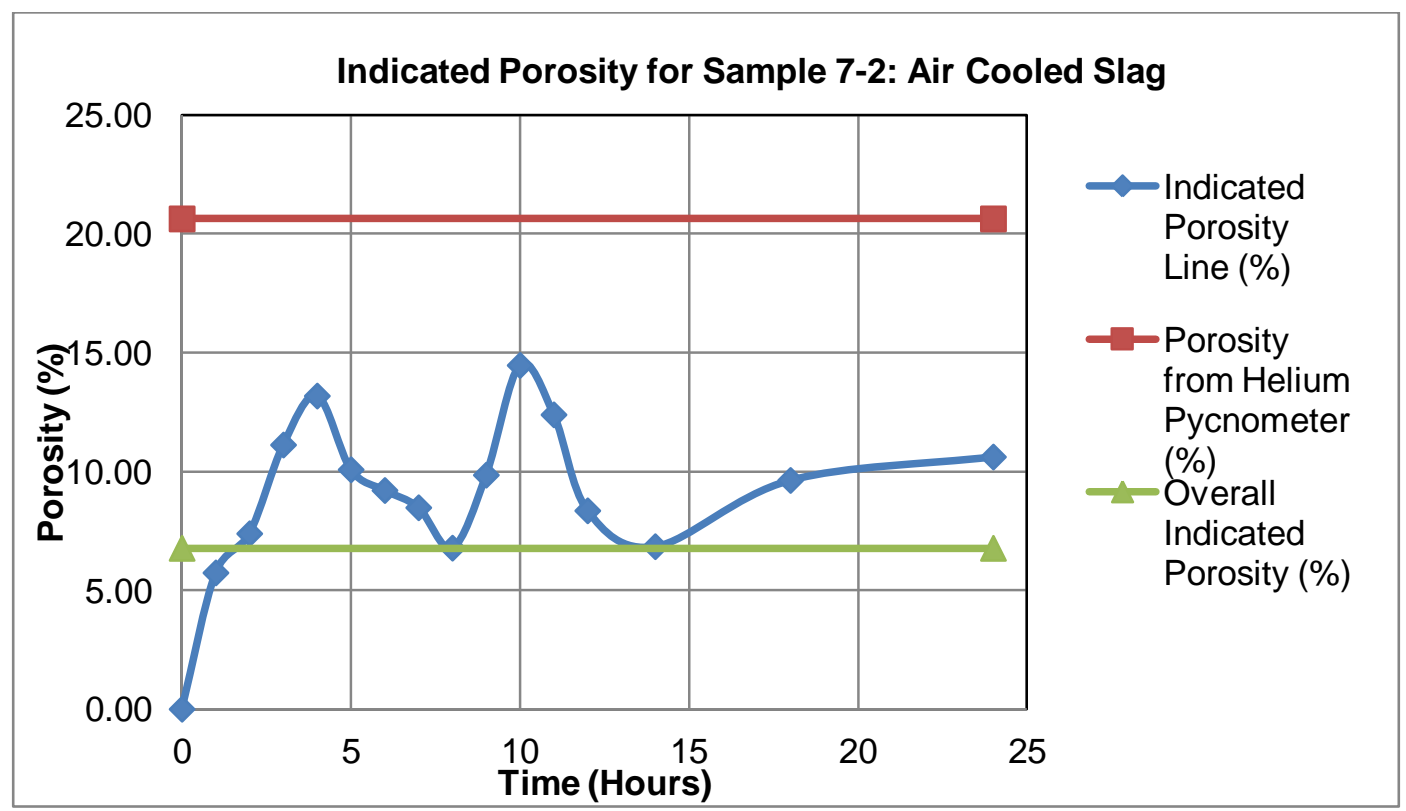

Figure 5-25: Indicated Porosity Graph for sample number 7-2, Air Cooled Slag 


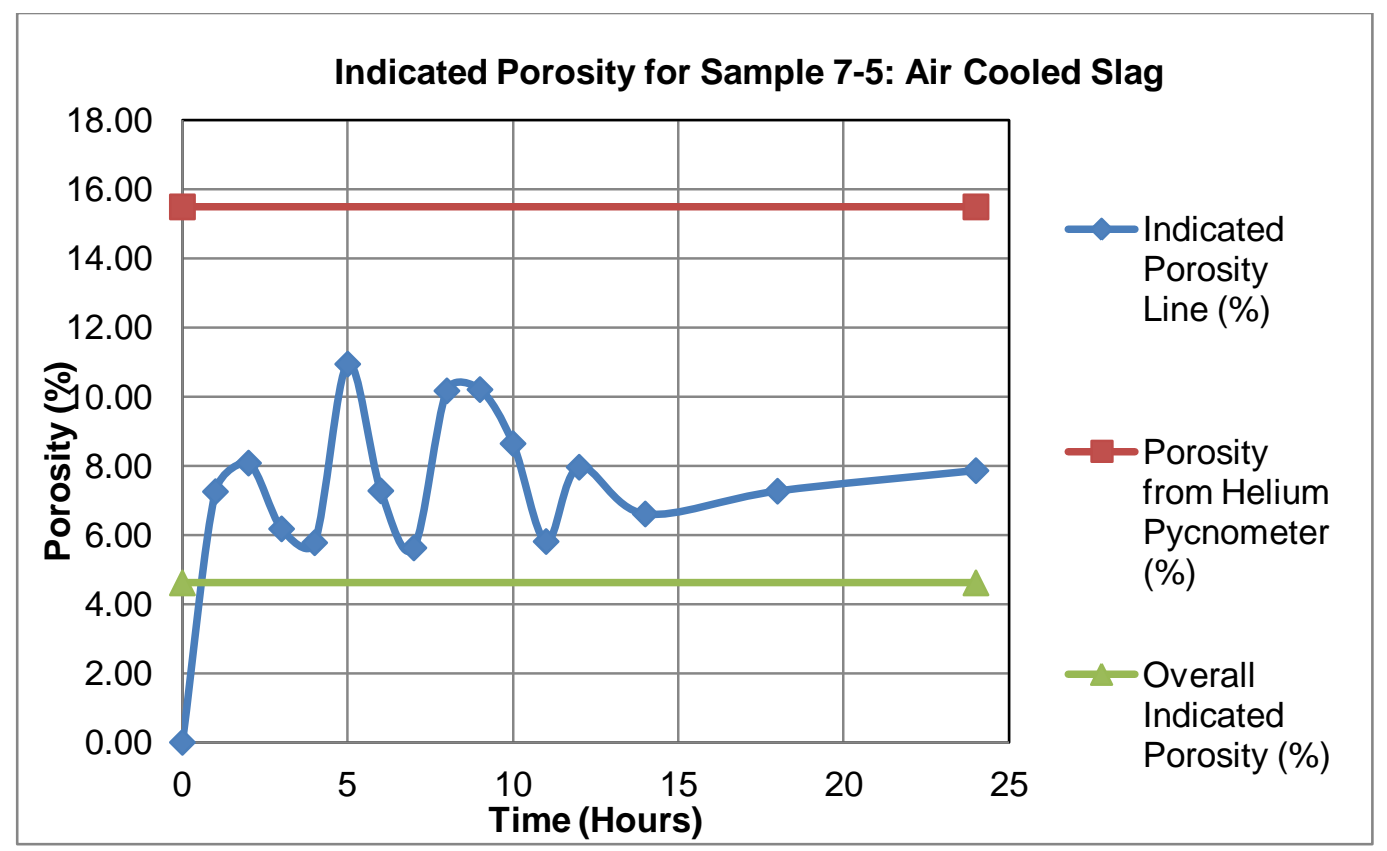

Figure 5-26: Indicated Porosity Graph for sample number 7-5, Air Cooled Slag

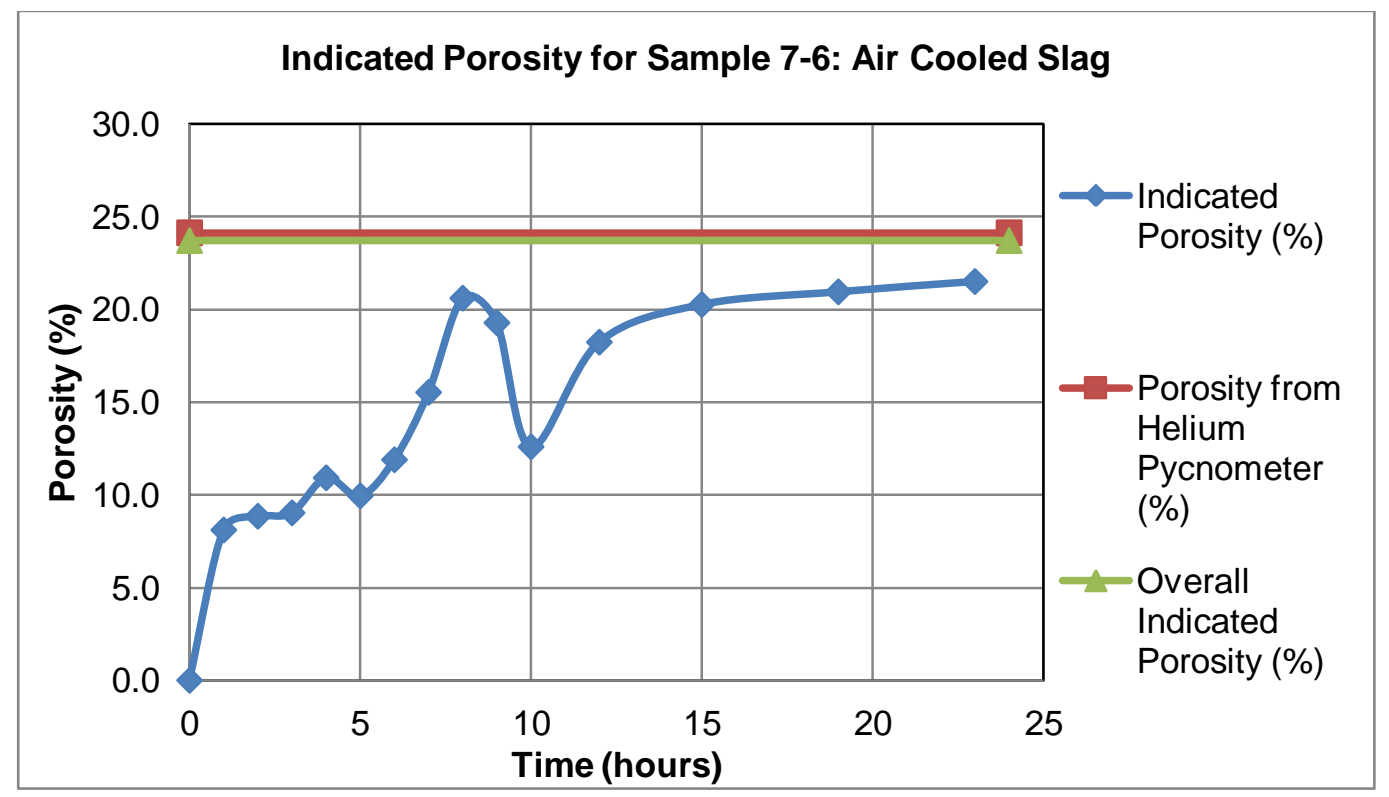

Figure 5-27: Indicated Porosity Graph for sample number 7-6, Air Cooled Slag

As the graphs above detail in the majority of cases the SSD method does not accurately represent the SSD density of the material. While the degree of difference between the two 
methods varies depending on the material being used caution should be utilized when using the SSD method.

\section{Future Work}

Additional testing should be completed with additional samples and different rock types. Overall, the samples selected for these experiments represent only a small fraction of the types of rocks and aggregates in use today. The blast slags were selected to serve as a worst case scenario due to the large volume of surface pores in the samples, and how deep some of the pores went into the sample. While a large number of the remaining carbonates comprising rock type number four contained some volume of surface pores, there was no intermediate sample that fit in between the two slag samples and the carbonates.

Additional testing should also be completed using the procedures outlined in ASTM C127-07 using the saturated surface dry methods. By taking measurements at regular intervals over the course of a forty eight hour long period it was proven that many samples had not yet reached their complete level of saturation.

Another area to explore would be the process of trying to alleviate the potential for human error in these tests. Even the automatic method tested, the helium pycnometer has the potential for human error if the sample weight is recorded or entered wrong.

\section{Conclusion}

Density appears to be an easy concept to understand. At its most basic definition, it is a very simple and straight forward concept. Simply divide the mass of an object by the volume. However, when it comes time to start adding in additional factors like porosity, permeability, absorption rates, pore sizes, and the processes that form the samples themselves things can easily become complicated. Most things in the geotechnical engineering world do not fall in perfect geometric shapes, so the ability to accurately assess the volume of a sample is vital.

In some situations, being inaccurate by as little as $0.05 \mathrm{~g} / \mathrm{cm}^{3}$ could cause widespread errors when that value is multiplied in order to reflect a large mass or volume. Of the methods 
tested, the Wax-Shrink Wrap Immersion method seemed to be the most universally applicable method. This method was extremely useful for the "worst case scenario" samples of water and air blast slags. Since the internal volume of the voids is supposed to be included in the volume for the determination of a bulk density, the shrink wrap helped to add another layer in order to help seal the pores off from the water.

In the case of less permeable rocks such as the granite or the Kona Dolomite it is not necessary to add two layers of material to the sample. In many cases, as long as the water immersion takes places relatively quickly, it is still possible to obtain an accurate density value.

The greatest limitation that remains to any of these measurements is the aspect of human error that will always be present. This is especially true in cases where numbers need to be selected quickly, such as with water immersion trials where determining the submerged weight must happen before the water begins to permeate the sample.

Overall, the Wax Immersion method is the recommended method for the determination of bulk density. Additional research should be done into whether or not there is another acceptable method for the determination of particle density. 


\section{References}

ASTM. (2004). C914-95: Standard Test Method for Bulk Denssity and Volume of Solid Refractories by Wax Immersion (pp. 188-190). West Conshohocken, PA: ASTM International.

ASTM. (2009). C127-07: Standard Test Method for Density, Relative Density (Specific Gravity), and Adsorption of Coarse Aggregate (pp. 76-81). West Conshohocken, PA: ASTM International.

Dominy, S., Noppe, M., Annels, A. (2002). Errors and Uncertainty in Mineral Resource and Ore REserve Estimation: The Importance of Getting it Right

Exploration Mining Geology, 11(1-4), 77-98.

Laboratory Manual in Physical Geology. (2003). Upper Saddle River, New Jersey: Macmillan Publishing Company.

Micromeritics. (1995). AccuPyc 1330 Pycnometer: Operators Manual. Norcross, GA.

Vitton, S. J., Lehman, M.A., Van Dam, T.J. (1998). Automated Soil Particle Specific Gravity Analysis Using Bulk Flow and Helium Pycnometry. American Society for Testing and Materials, ASTM STP 1350(Nondestructive and Automated Testing for Soil and Rock Properties).

Vitton, S. J., Subhash,G., Dewey, G. (2002). Evolution of the Dynamic Fracture Characteristics of Aggregate in PCC Pavements. Houghton, MI: Michigan Department of Transportation.

Webb, P. A. (2001). Volume and Density Determination for Particle Technologies: Micromeritics Instrument Corp. 


\section{Appendix A: Sample Preparation and Description of Rock Types}

\section{Sample Preparation and Selection}

One of the major goals when selecting the rocks for this project was to ensure that a wide variety of geologic origins, porosities, hardness and permeability were represented. This was done in order to attempt to encounter the majority of issues with rock that most companies face. Overall seven different kinds of rocks were selected from various locations around the state of Michigan. To identify each core as to what type of rock as well as which rock the core came from each core was assigned a unique number consisting of three parts.

Samples were cored using $17 / 8$ inch diameter or NQ sized bit that was manufactured by Hoffman Diamond Products of Punxsutawney, Pennsylvania. To help minimize any variations in the diameter of the cores care was taken to minimize the possibility of any lateral movement of the rock by firmly securing the rock to the drill press. Bits were also checked on a regular basis to ensure that there was still enough of a cutting edge remained to easily core the rock.

The cores were then cut to a 2:1 ratio using a rock saw. In some cases it was not possible to hit a true 2:1 ratio. One reason for this was that the rock the core was taken from originally was not thick enough to produce a core the proper length or that during the cutting or coring process the rock broke into several pieces. In either case the sample was created from the longest remaining length of core.

After each round of testing and after cutting, the samples were dried for a period of 24 hours ( \pm 4 hours) a $110^{\circ} \mathrm{C}$ oven. This was done to remove any trapped moisture in the sample and to ensure that all densities calculated were a dry density.

Pictures of all Rock Samples used and descriptions of the rock type are shown below The scale at the bottom of all photos is in centimeters. Included for visual reference where necessary is an image from the Laboratory Manual in Physical Geology published by the American Geological Institute (Institute, 2003). 


\section{Rock Type 1: Granite}

The Granite utilized was quarried in north Marquette County, Michigan. Three cores of Granite were used during testing however four samples were prepared but during testing sample 1-1-3 was chipped and rendered unusable.

The granite was a phaneritic rock with visible crystals of biotite mica, feldspar and quartz that on average were $2-3 \mathrm{~mm}$ in size. Mineralogy of the granite consisted of about $50 \%$ quartz that was identified as being milky white/ grey in color. There was only minimal feldspar in the sample, making up about $10 \%$ of the core and was identified as being the pinkish orange coloration in the core. Some cores did contain a larger amount of feldspar than others but for the most part the feldspar was limited to small crystals that were only about $1 \mathrm{~mm}$ in size. This lack of feldspar on the sample gave the Granite a salt and pepper coloration that was mostly white and black. The other roughly $40 \%$ of the sample was composed of biotite mica. On the cut ends of the sample the distinctive cleavage of the biotite was very visible.

Overall the granite had a very smooth texture and felt dense when handled. During the sample preparation process the Granite was very difficult to work with. Due to the denseness and hardness of the rock it was difficult to get the drill bit to bite into the rock and core easily. The bit had a tendency to slip off to the side of the sample and have side-to-side vibrations during coring. This difficulty in coring also caused problems when cutting the sample as the saw did not want to go through the rock.

Granite Sample: 1-1-1

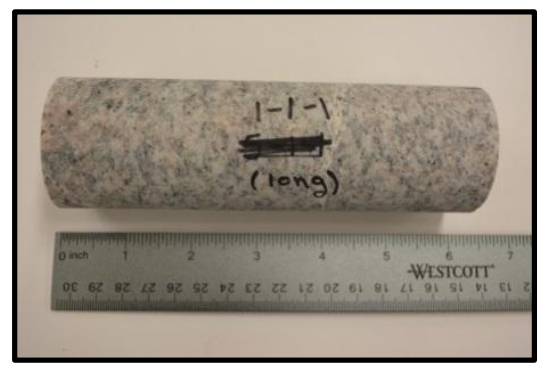


Granite Sample: 1-1-2
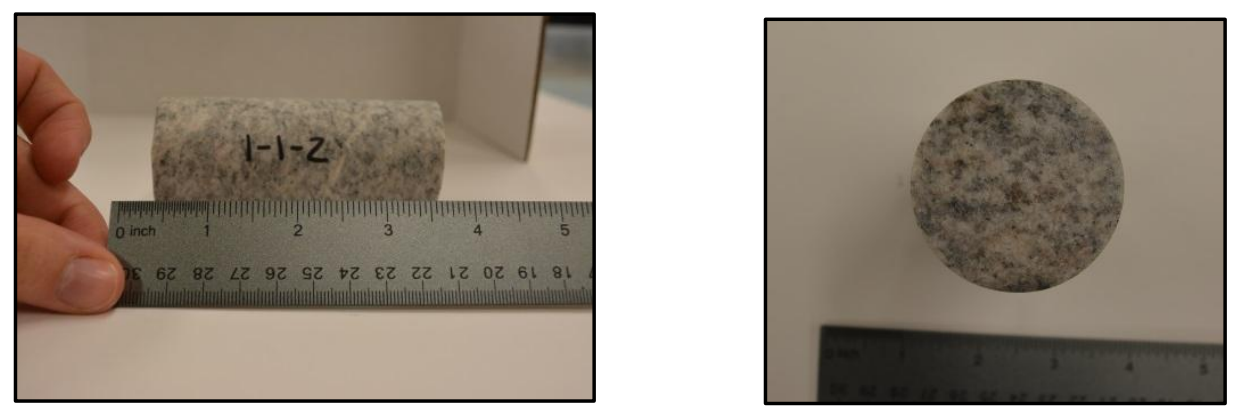

Granite Sample: 1-1-4
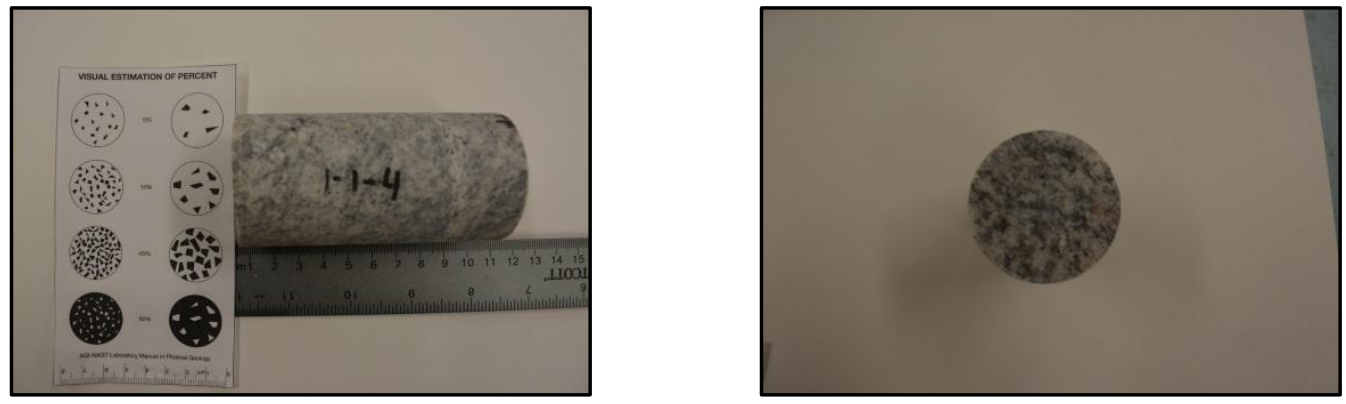

\section{Rock Type 2: Kona Dolomite}

The Kona Dolomite was from 480 Pitt near Marquette, Michigan. This rock had coloration that varied from almost white to a dark reddish purple that swirled together throughout the sample giving it a mottled appearance.

This dolomite in an example of a secondary replacement product of chemically precipitated limestone. This rock has a very high quartz content that accounts for the lighter coloration in some samples. All samples felt reasonable heavy for their size and had a smooth texture and were very competent and strong. During sample preparation none of the cores experienced breakage or cracking but were difficult to drill and cut to size.

Ten cores of Kona Dolomite were used from two different rocks. 
Kona Dolomite Sample: 2-1-1

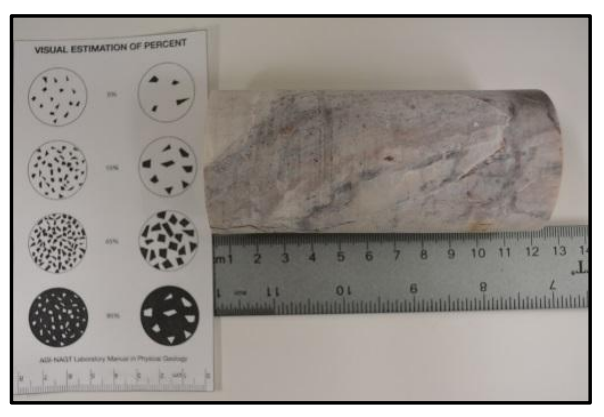

Kona Dolomite Sample: 2-1-2

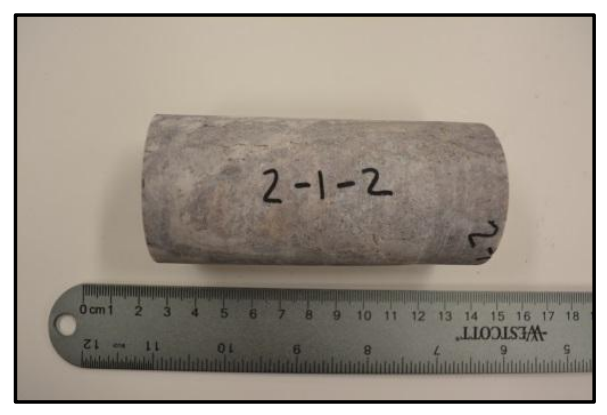

Kona Dolomite Sample: 2-1-3

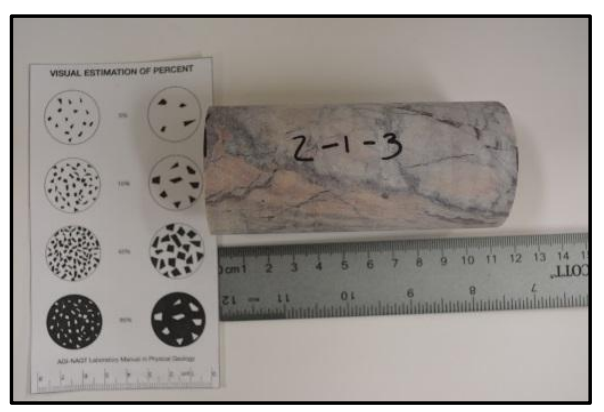

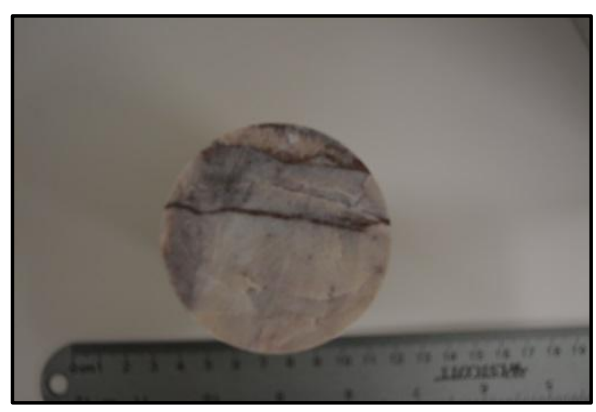
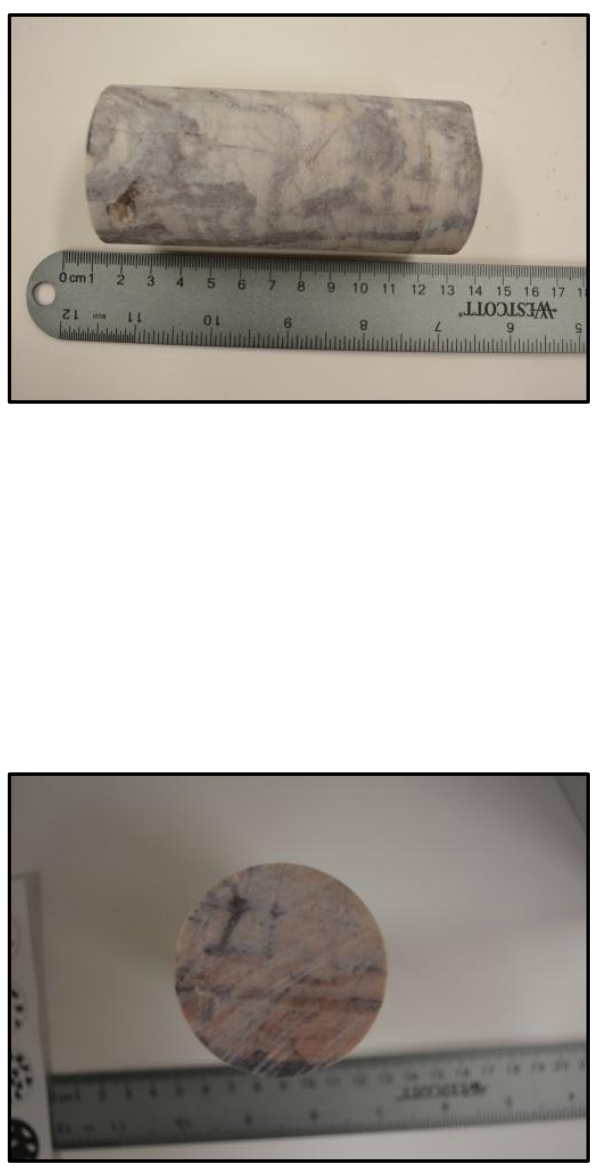
Kona Dolomite Sample: 2-1-4

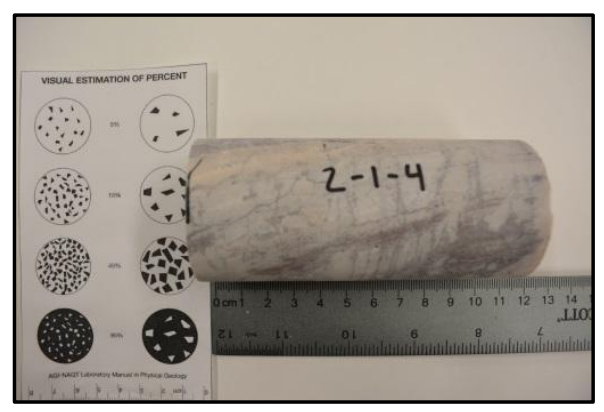

Kona Dolomite Sample: 2-2-1

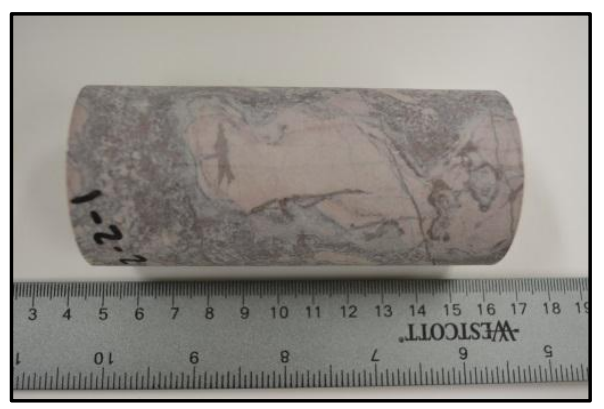

Kona Dolomite Sample: 2-2-2

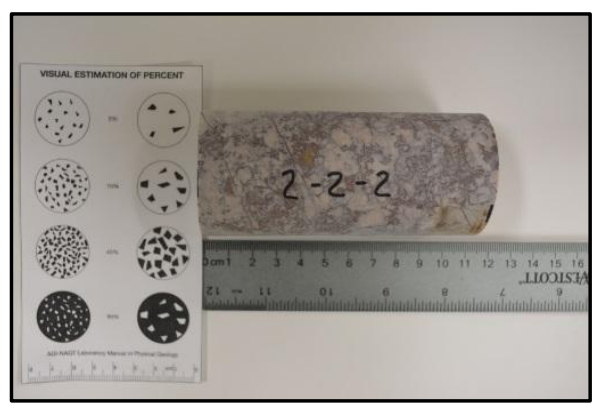

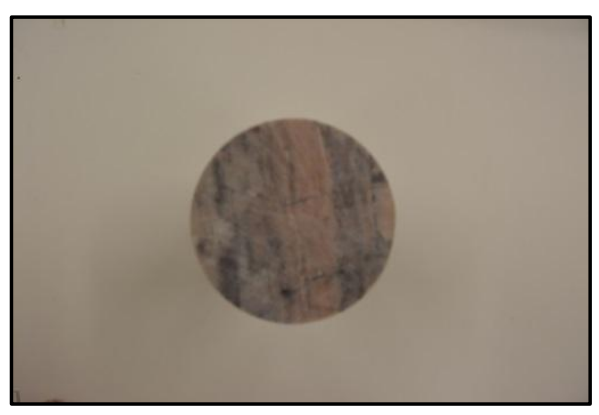
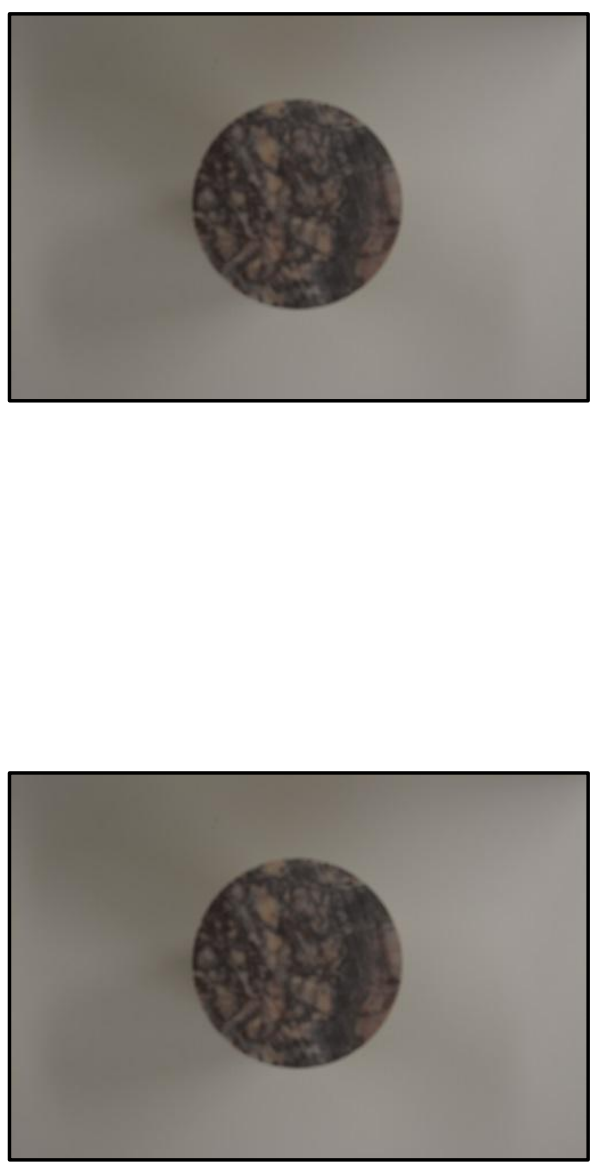
Kona Dolomite Sample: 2-2-3
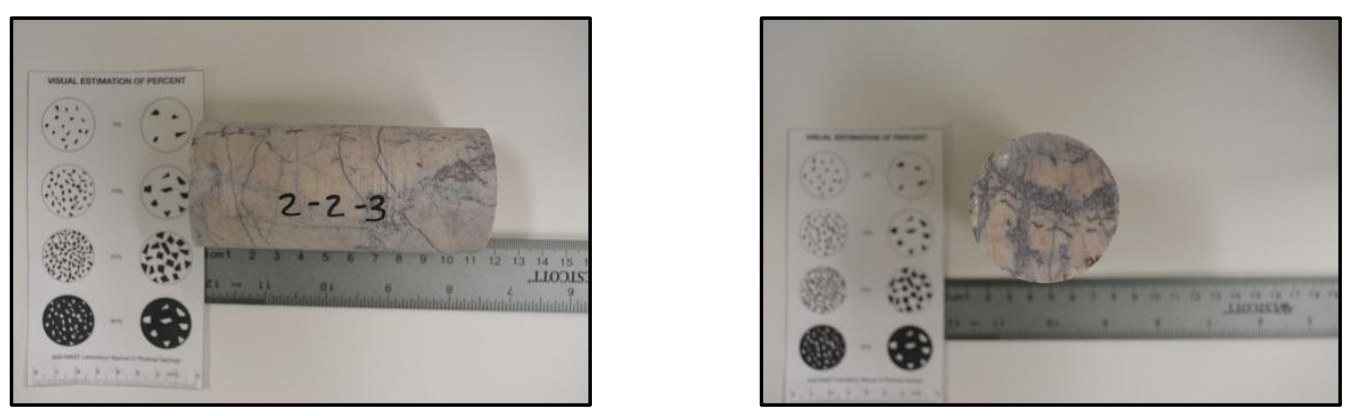

Kona Dolomite Sample: 2-2-4
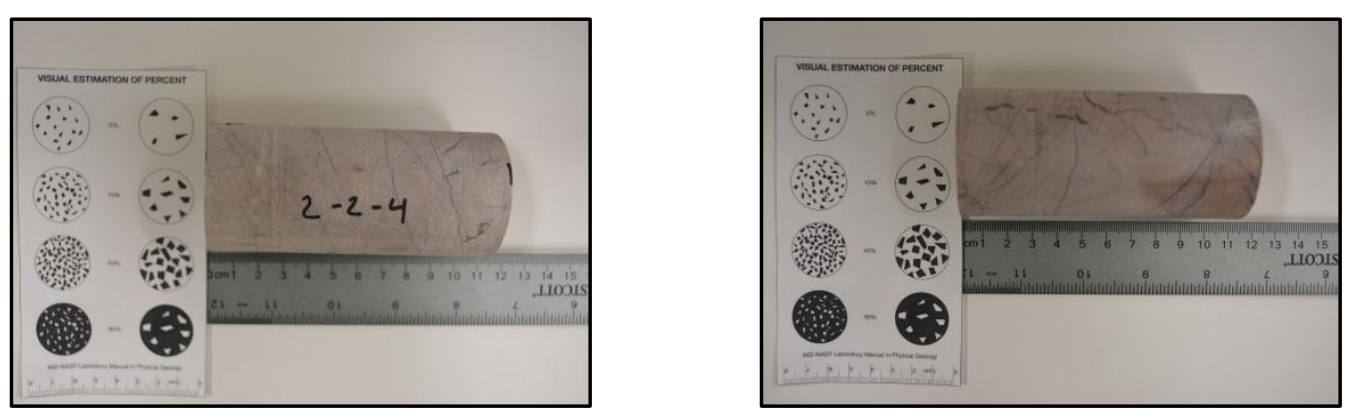

Kona Dolomite Sample: 2-2-5
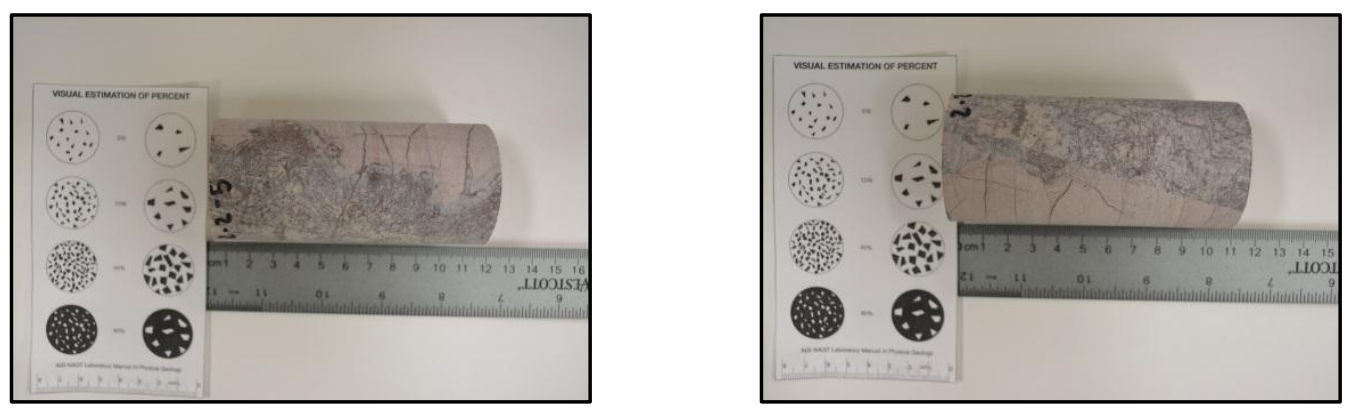
Kona Dolomite Sample: 2-2-6
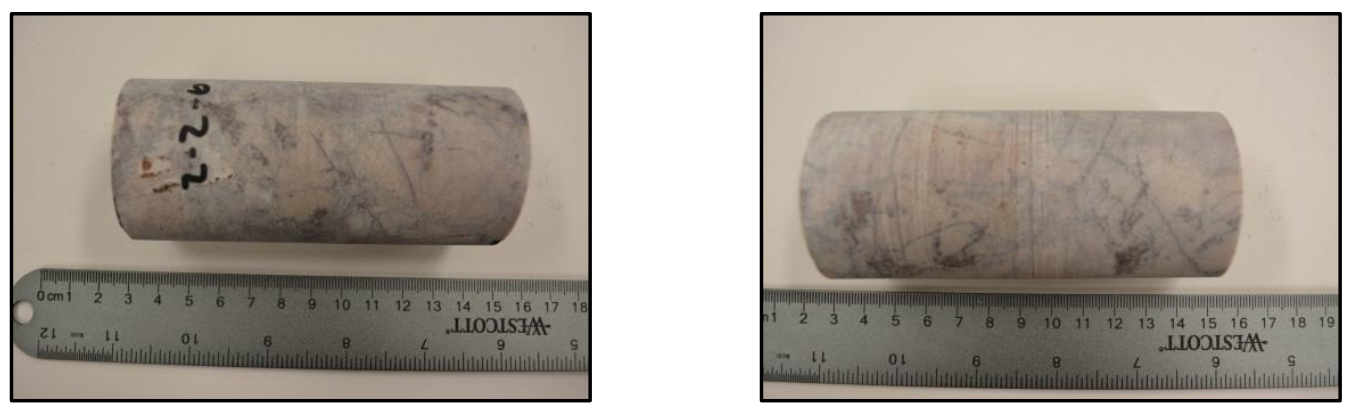

\section{Rock Type 3: Dolomite from Pelkie Michigan}

The two samples from rock type three were two of the shorter samples used during testing.

This light tan/white colored rock was from Pelkie, Michigan and is officially classified as a dolomite which was also proven by the density of the sample being about $2.8 \mathrm{~g} / \mathrm{cm}^{3}$. When looking at the sides of these rocks it was possible to see what may have once been bedding planes in the rock. These lines were a darker grey/green color and were oriented horizontally in the sample but were not parallel to the surface. This rock had a microcrystalline structure with no visible grains.

This rock was reasonably difficult to work with on account of its tendency to break into smaller pieces. While the rock that was being cored was over four inches thick, during the coring process it was not uncommon for the sample to break into three or four sections. The cores selected were from the two longest sections of core that were recovered, in some instances no pieces longer than one inch were removed from the rock. Majority of the breaking appeared to happen along the horizontal bands described above.

Also visible on these samples was minor dark brown staining. 
Pelkie Dolomite Sample: 3-2-1
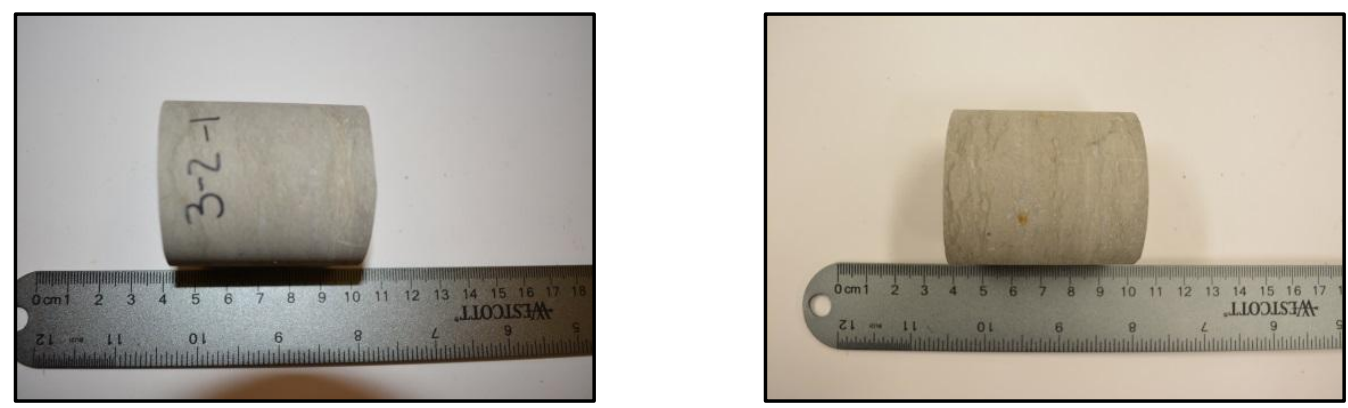

Pelkie Dolomite Sample: 3-3-1
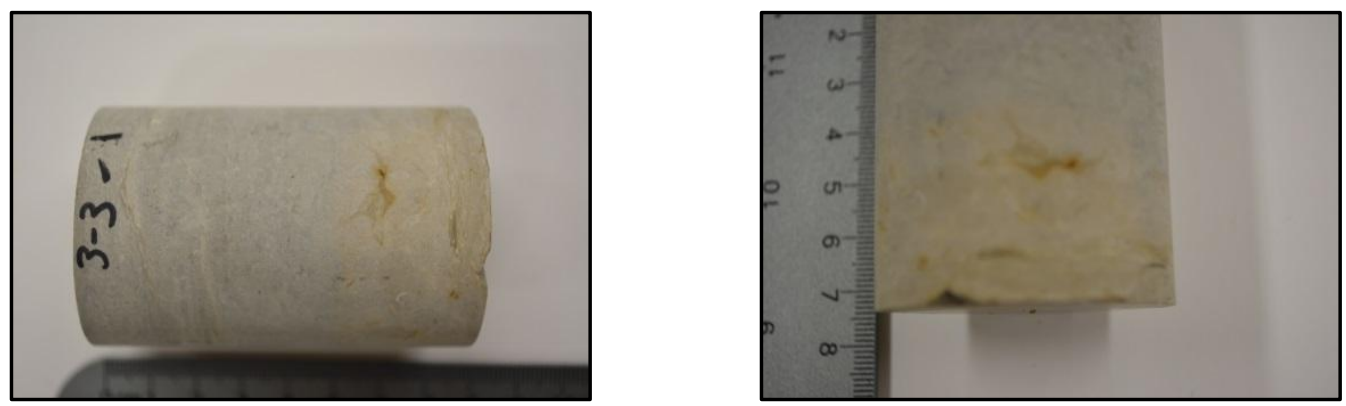

\section{Rock Type 4: Various Carbonates from Lower Peninsula, Michigan}

While five rocks were cored in from this type there are only two main types of rocks identified. The first can be seen below in Figure A-1. This rock type was represented by samples numbered 4-1-X and 4-5-X. As seen below these samples had a microcrystalline structure that was very smooth. Some samples did have small surface voids that contained light colored crystals that reflected light. Coloration on these samples was mostly a very pale grey, almost white that was marbled with a darker mid blue grey coloration. These rocks were very competent and dense. 


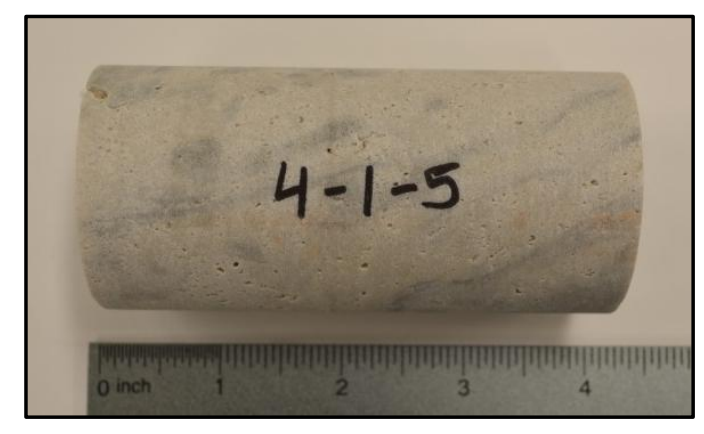

Figure A-1: Sample 4-1-2 showing the marbled white a gray coloration indicative of these samples as well as the typical surface pores visible on the samples.

The other type of rock is visible in 4-2-X through 4-4-X. While each sample varies a small amount in terms of length and open pore space, the overall differences in these samples are minimal. Between $5-10 \%$ of the samples surface are were covered in small scale surface pores that are typically less than $5 \mathrm{~mm}$ in any dimension. The same horizontal wavy banding visible in the two samples from rock type 3 are also visible in these samples. For those rocks coming from 4-3-X they were cut to the longest length possible which was not the 2:1 ratio that was aimed for as the rocks provided were less than four inches long. Sample 4-2-1 is shown below in Figure A-2.

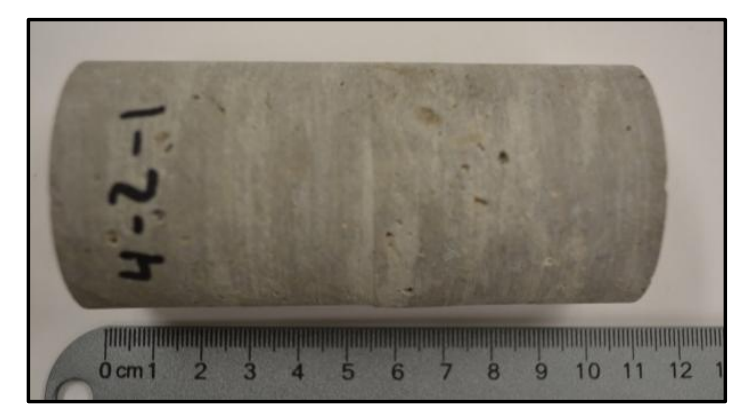

Figure A-2: Sample 4-2-1 showing the typical coloration and void dimensions for rocks coming from this series 
Sample: 4-1-1
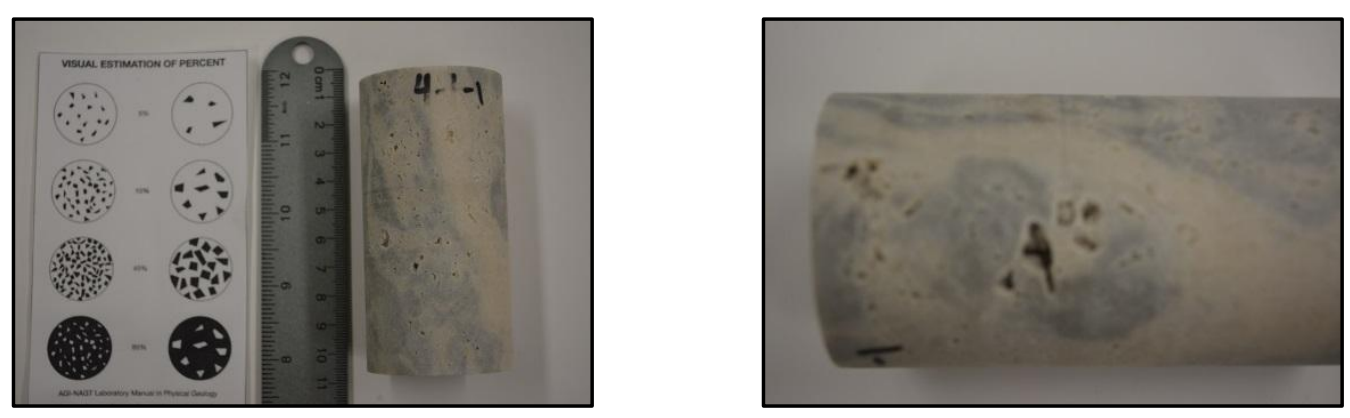

Sample: 4-1-2
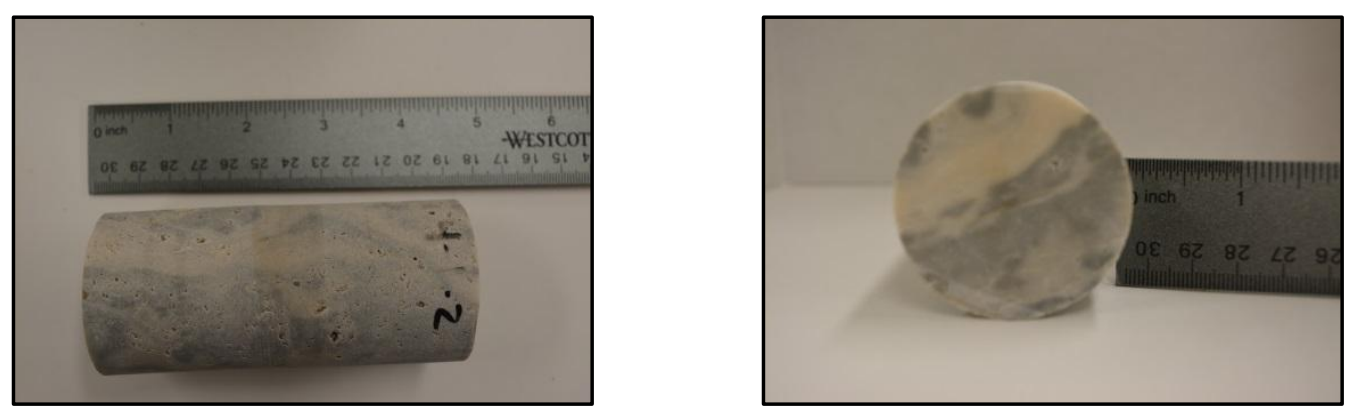

Sample: 4-1-3
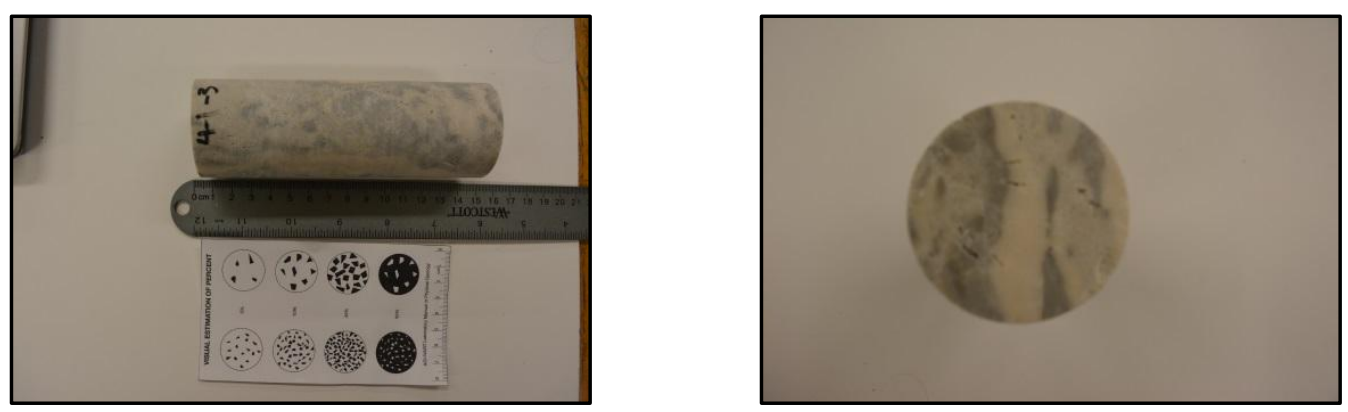
Sample: 4-1-4
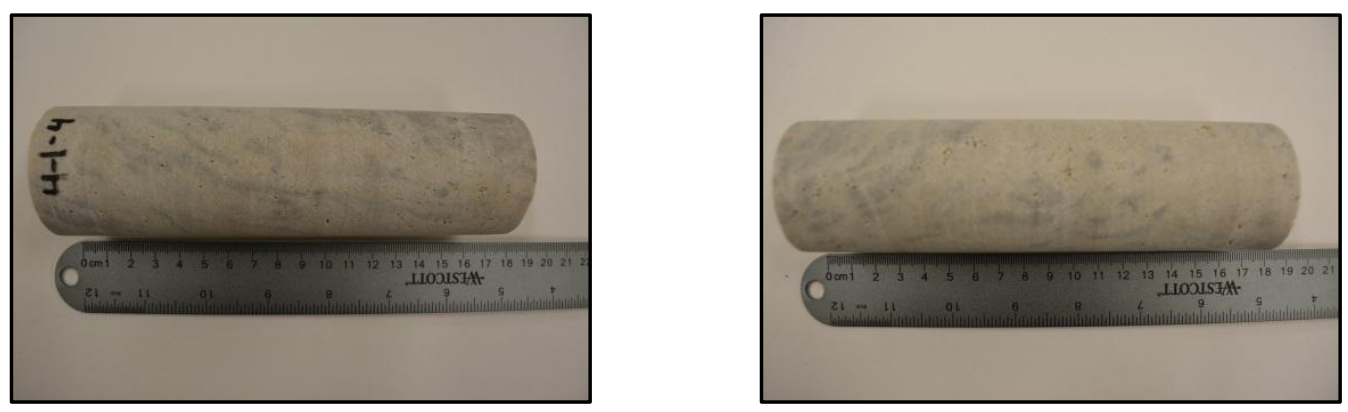

Sample: 4-1-5
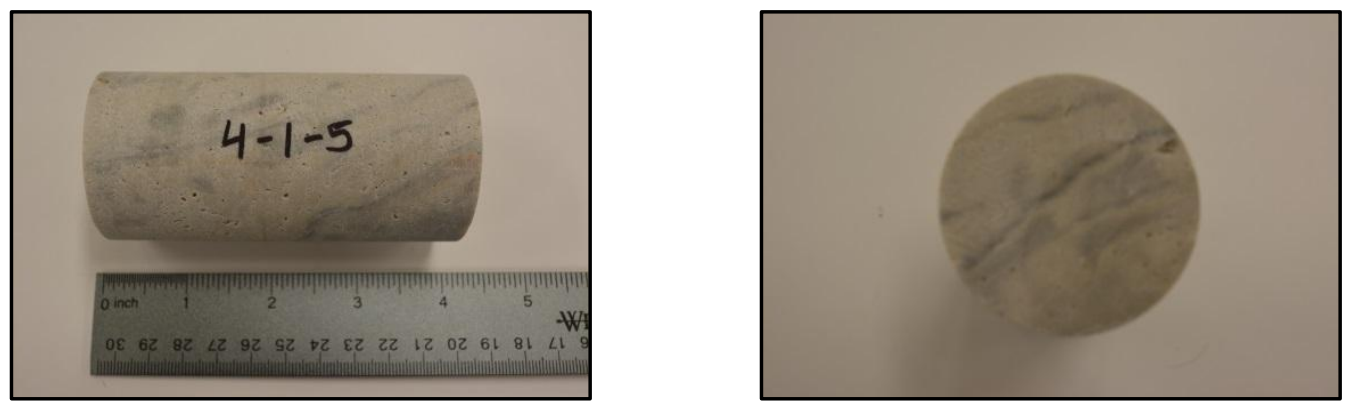

Sample: 4-2-1
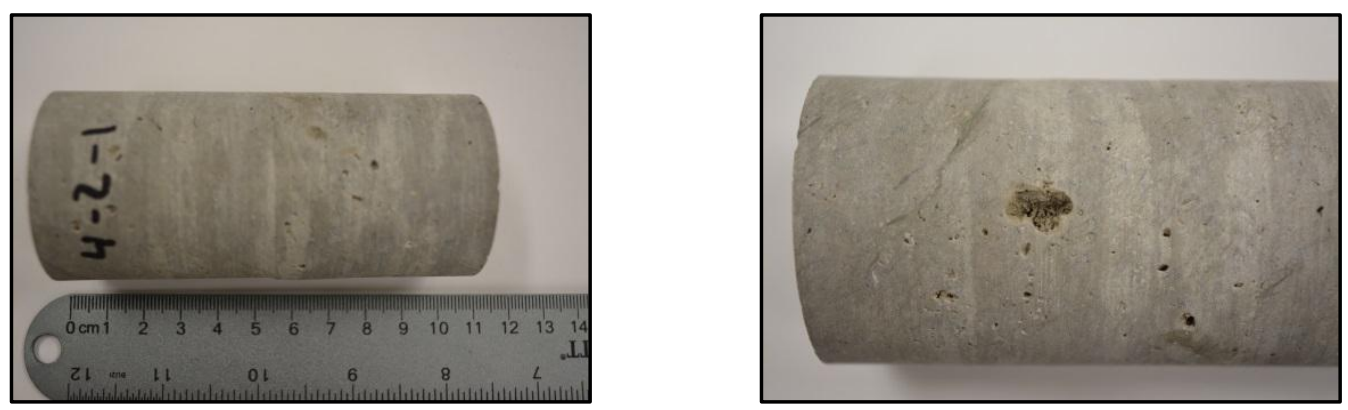
Sample: 4-4-2

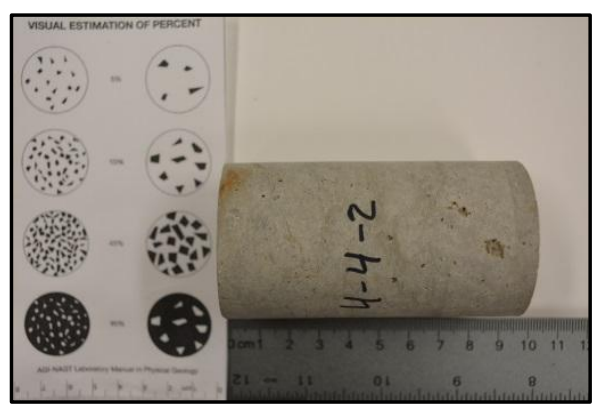

Sample: 4-4-3

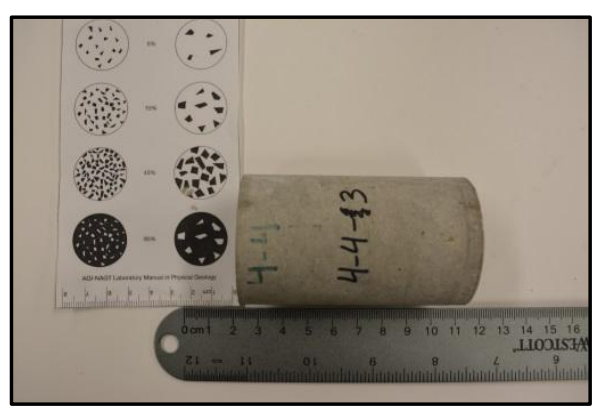

Sample: 4-5-1

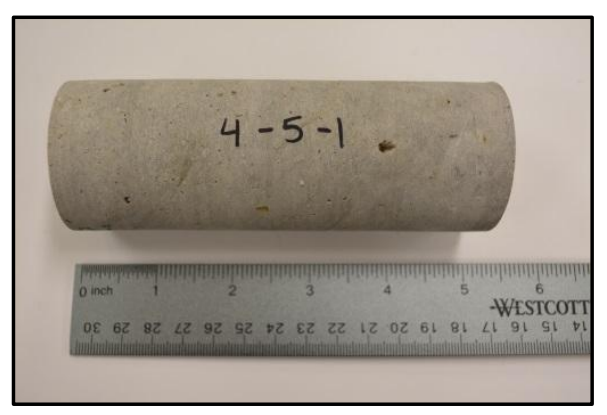

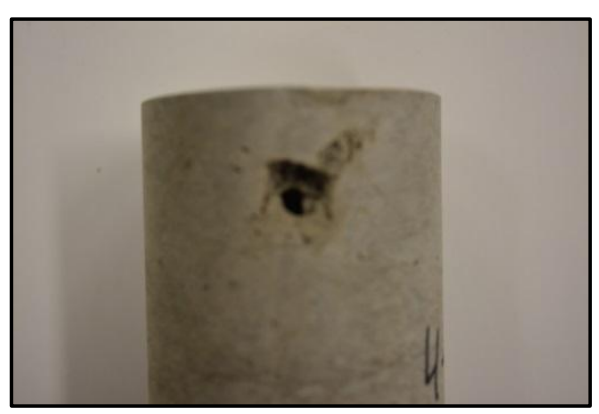
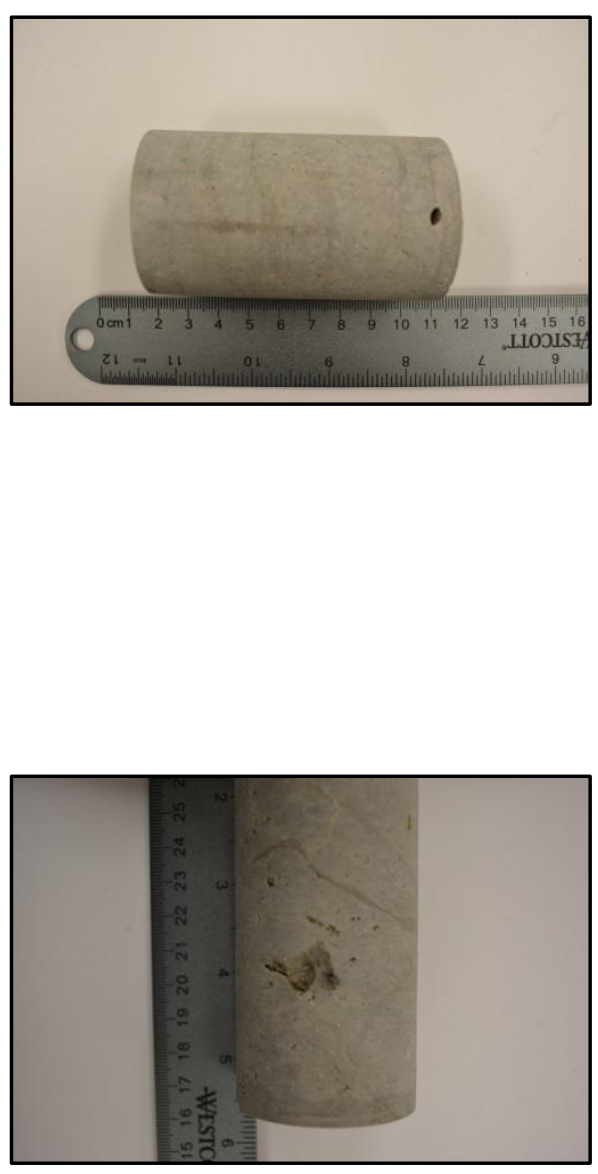


\section{Rock Type 5: Water Cooled Slag}

The slag chosen to represent Water cooled slag was originally created at one of the steel mills used for the automotive industry. While all the samples were created at the same time the cooling process creates different characteristics. Based on these visible characteristics the Water Cooled Slag rock type was divided up into three different types based on the physical appearance of the slag (pore size/shape, coloration ect).

Slag is a byproduct of the manufacturing of pig iron in the steel industry. The slag is the lighter material that comes to the top of the furnace while the heavier pig iron sinks to the bottom. Today this material that was once a waste product is used as a manufactured aggregate. During the steel making process after the pig iron is collected from the furnace the slag from the top is placed in shallow trenches and sprayed with water to speed up the cooling process resulting in slag that is water cooled (S. J. Vitton, Subhash,G., Dewey, G., 2002). After cooling the slag was broken up into smaller blocks that are roughly $1 \mathrm{ft}$ by $1 \mathrm{ft}$ blocks.

The cooling process results in characteristics that are similar to what is seen in lava flows as they cool. As the water is sprayed on the slag it causes the top layers to cool at a faster rate than the bottom causing stratification of the sample. As gasses are trapped near the surface large air bubbles are frozen into the rock forming internal and surface voids that can be upwards of one centimeter in diameter. The lighter minerals in the material will also float to the top causing the surface slag to have a lighter coloration than slag taken from the bottom of the trench(S. J. Vitton, Subhash,G., Dewey, G., 2002). The darker minerals will sink to the bottom of the trench resulting in a darker coloration to the slag. Also as the water during the cooling process cannot reach the slag it cools at a slower rate resulting in smaller bubbles. This segregation means that while all the samples from rock type 5 were from the same location, they had vastly different physical appearances.

Water cooled slag will result in a crystalline structure that has larger crystals than simply letting the slag cool at its own pace (S. J. Vitton, Lehman, M.A., Van Dam, T.J., 1998). This was seen when looking the Water Cool Slag and comparing it to the Air Cooled Slag; this is the reason the two slags' were placed in two unique rock types. Overall twelve cores were created of Water Cooled Slag and care was taken to sample from rock that originated from the top of the trench, the middle and the bottom in order to accurately represent the various forms of slag. 
The first kind of slag used can be seen in Figure A-3 below and appears to have come from the top of the slag trench. This slag had a very light coloration compared to other samples and can be best described as being a pale grey. Pores in these samples ranged from being circular to cylindrical and were normally in the size range of $5 \mathrm{~mm}$ in diameter though some were both smaller and larger than that size. Also of note is that after repeated heating and cooling cycles this slag actually produced sulfur precipitating out of some of the pores. This sulfur was pale yellow in color, brittle and soft. It was estimated that about $60-70 \%$ of the surface of these samples were covered in pores.

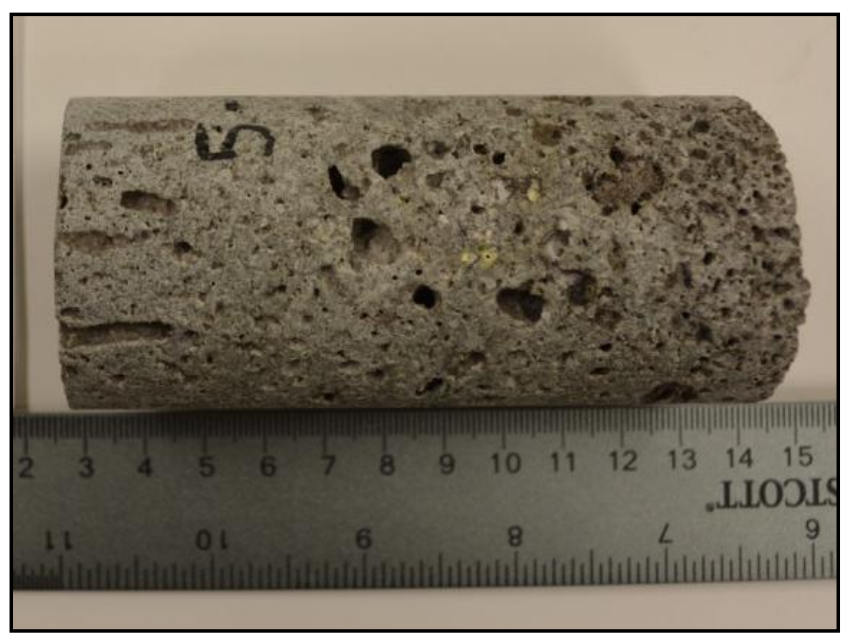

Figure A-3: Sample 5-1-1 representing the first type of blast slag from Levi, Michigan. Note the change in pore shape and the distribution of the pores down the length of the sample and the light grey coloration

The second type of blast slag had a more varied appearance. While the earlier type of slag had a wide range of pore sizes and depths this slag had very small pores that had hardly any depth. These pores were on the size range of $2 \mathrm{~mm}$ in diameter and the deepest pore was $3 \mathrm{~mm}$. Pores covered an estimated $70 \%$ of the top of the sample. These samples probably corresponded to the lower portion of the slag trench and also produced the sulfur precipitate after being heated. 


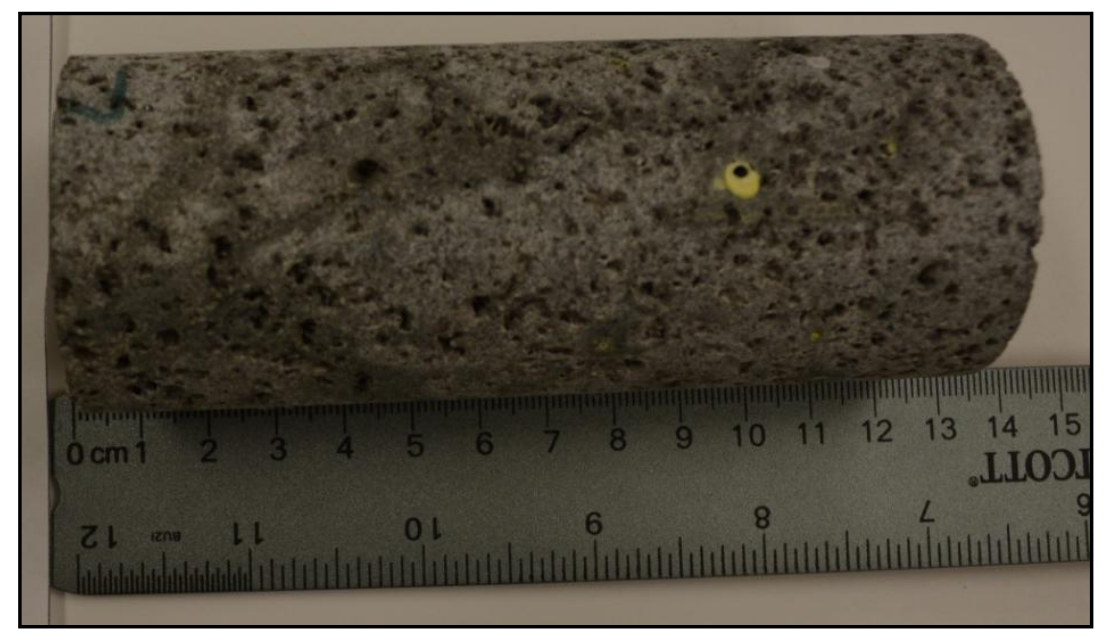

Figure A-4: Sample 5-2-3 representing the second type of Water Cooled Slag. The yellow is sulfur that leached out the sample during the heating process. Notice also the smaller average pore size and depth.

The final variety of water cooled slag can be seen in Figure A-5 below. This slag was the opposite of the above sample in that majority of the pores were large, deep and not very circular or uniform in size. This made coating the sample in wax very difficult as well as obtaining Water Immersion densities. As both these rocks came from the same rock sample it appears these samples represent the lower portion and upper half of the slag trench. An interesting side note is that these were the only samples to not precipitate out significant amounts of sulfur for this rock number.

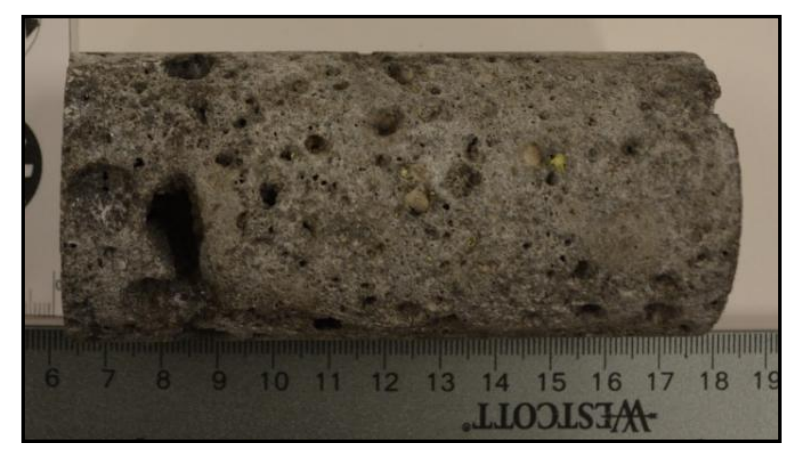

Figure A-5: Sample 5-2-1 representing the other pore distribution pattern for this series of blast slag. Notice the larger pore on the bottom end of the sample and the continuation of the smaller pore diameters along the opposite end. 
The three cores corresponding to the third type of Levi Slag had the darkest coloration suggesting that these rocks came from the bottom of the trench. Figure A-6 below shows what one of these samples looked like that was more massive than vesicular. There were a wide range of pore sizes and distributions present in these samples pores ranged in size from $1 \mathrm{~mm}$ in size up to $15 \mathrm{~mm}$ in size. These cores were typically the darkest in color and some had what looked like faults running through them as shown below that were identified by a dark brown material. The sulfur in these samples typically precipitated out around these fault like inclusions.

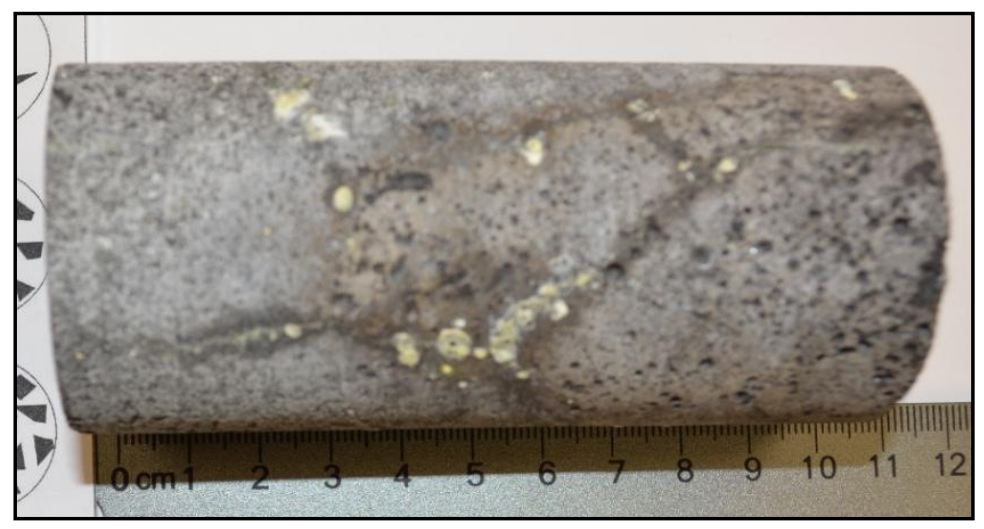

Figure A-6: The third type of Levi Blast Slag illustrating the precipitation out of sulfur along the fracture lines

The following pictures show the twelve samples tested for Water Cooled Slag.

Sample: 5-1-1
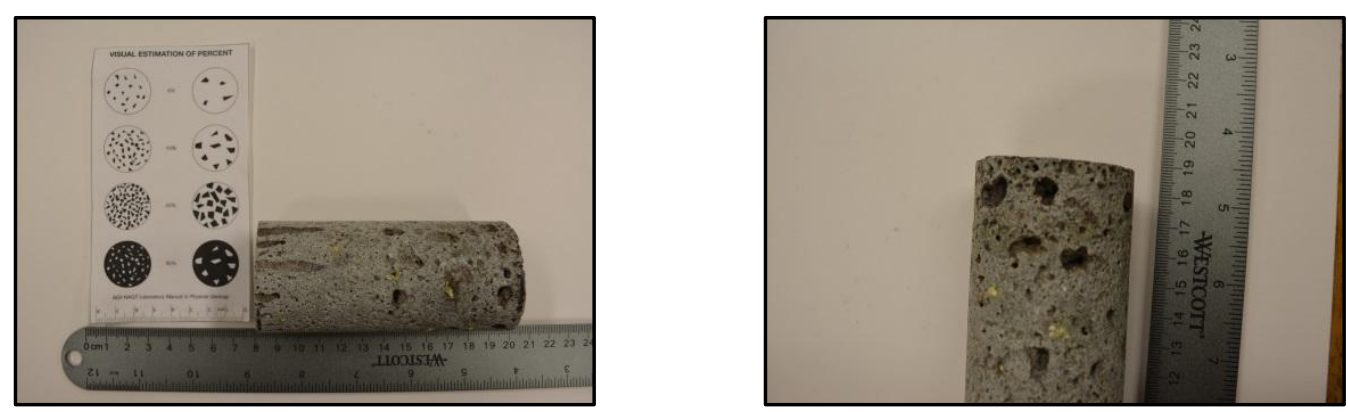
Sample: 5-1-2
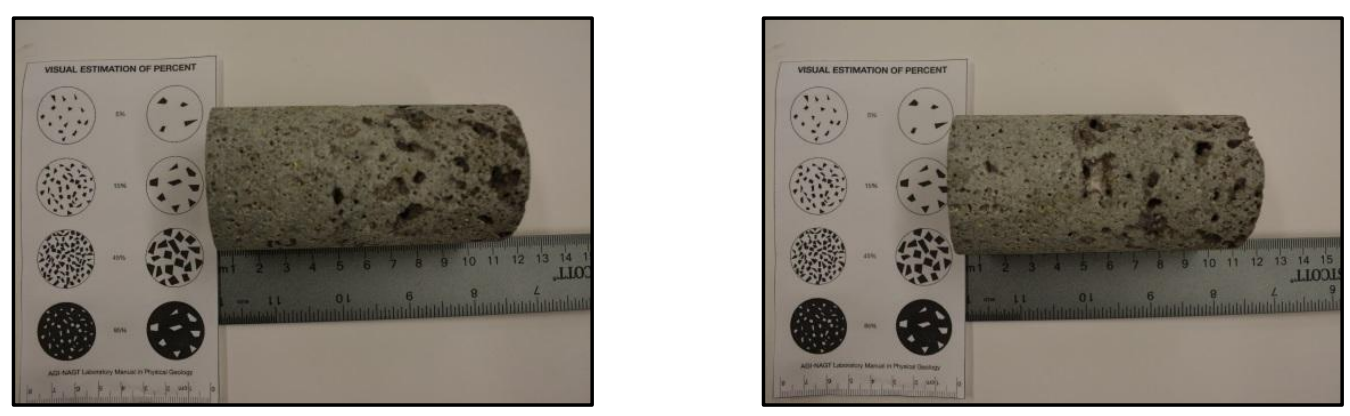

Sample: 5-1-3
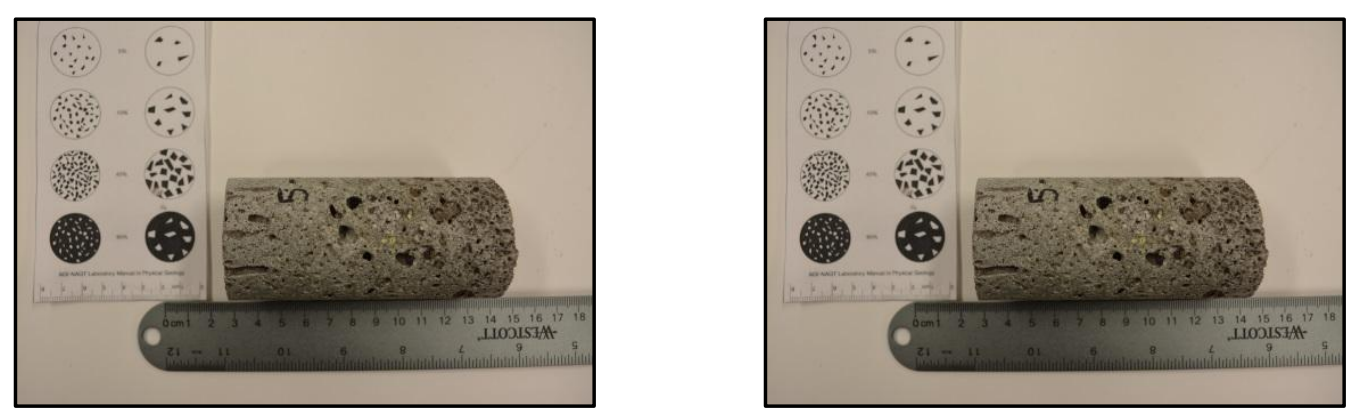

Sample: 5-1-4
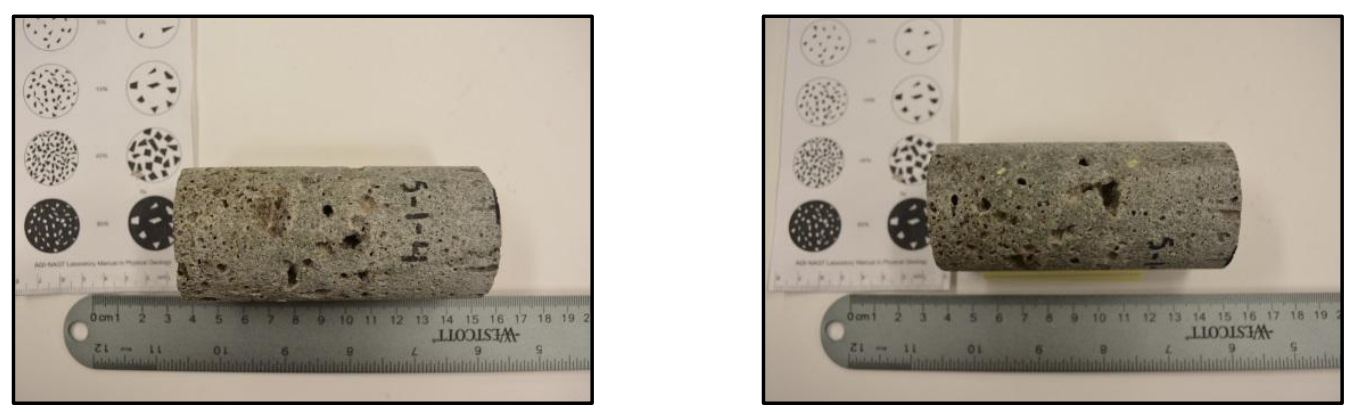
Sample: 5-1-5
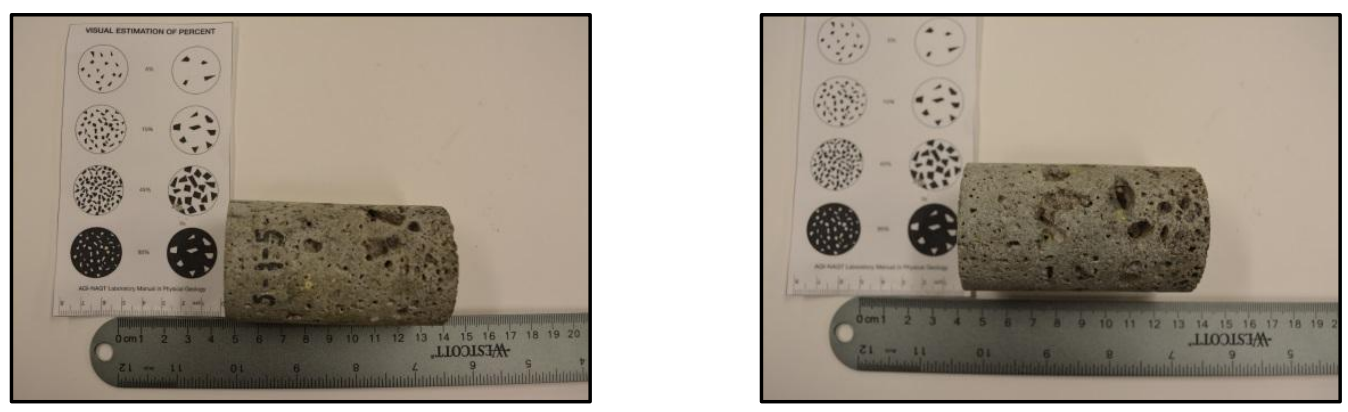

Sample: 5-2-1
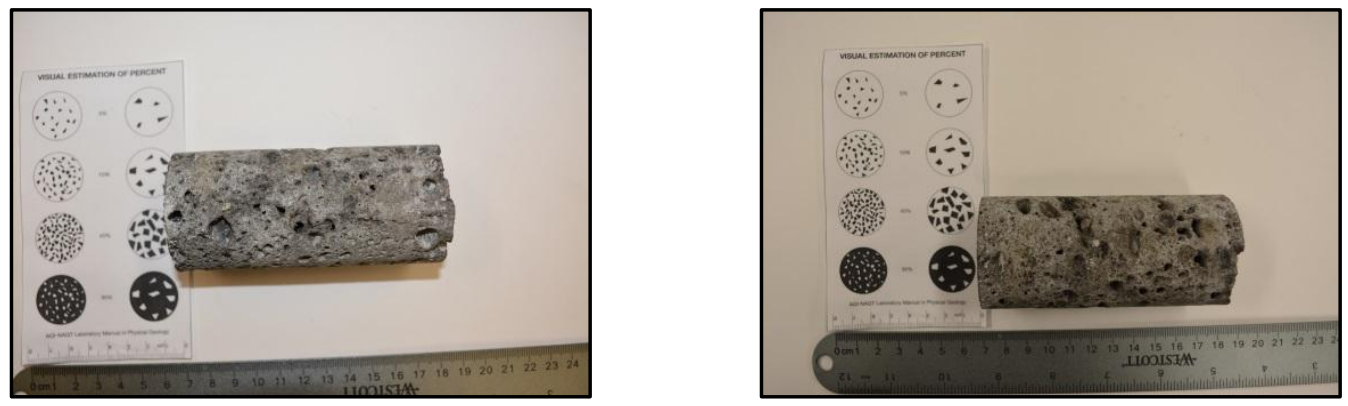

Sample: 5-2-2
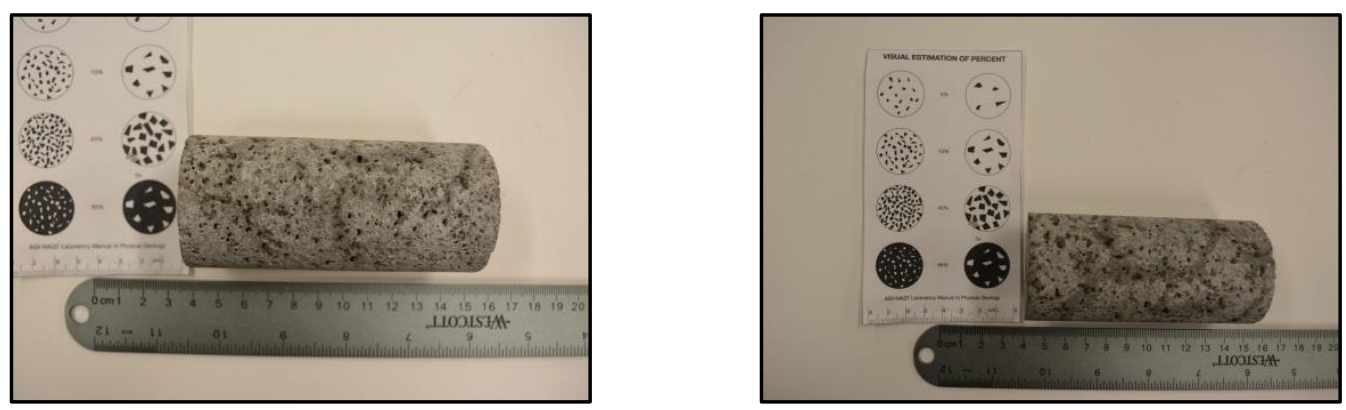
Sample: 5-2-3
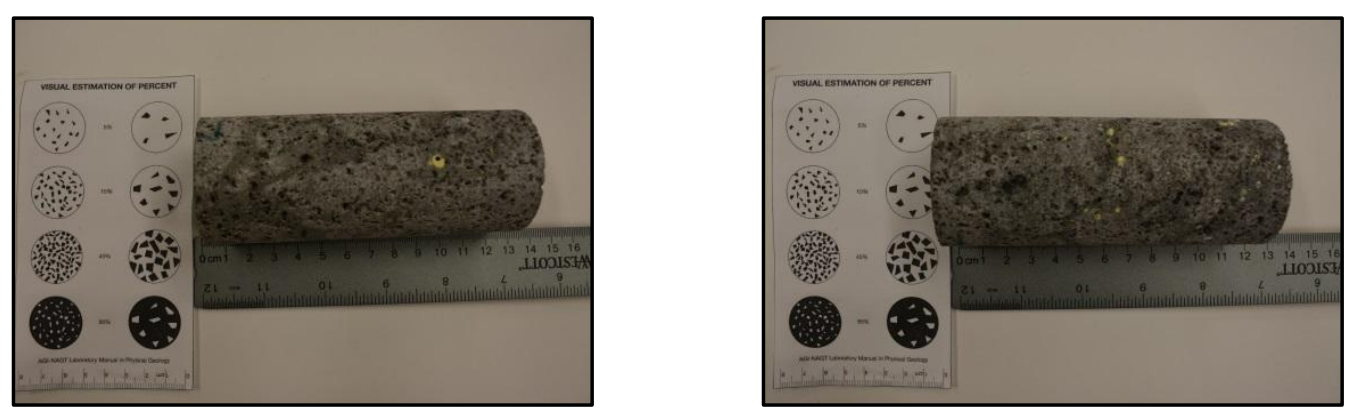

Sample: 5-2-5
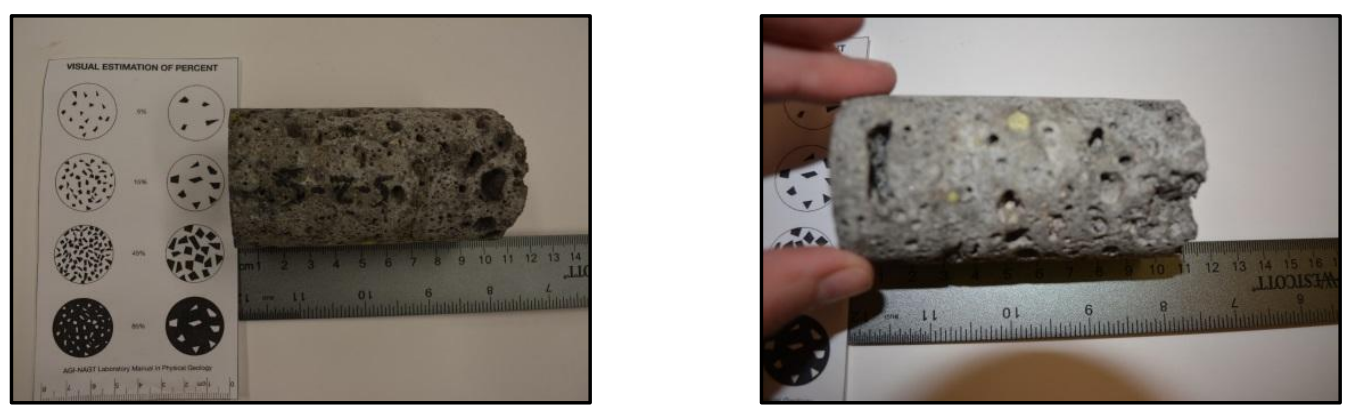

Sample: 5-3-1
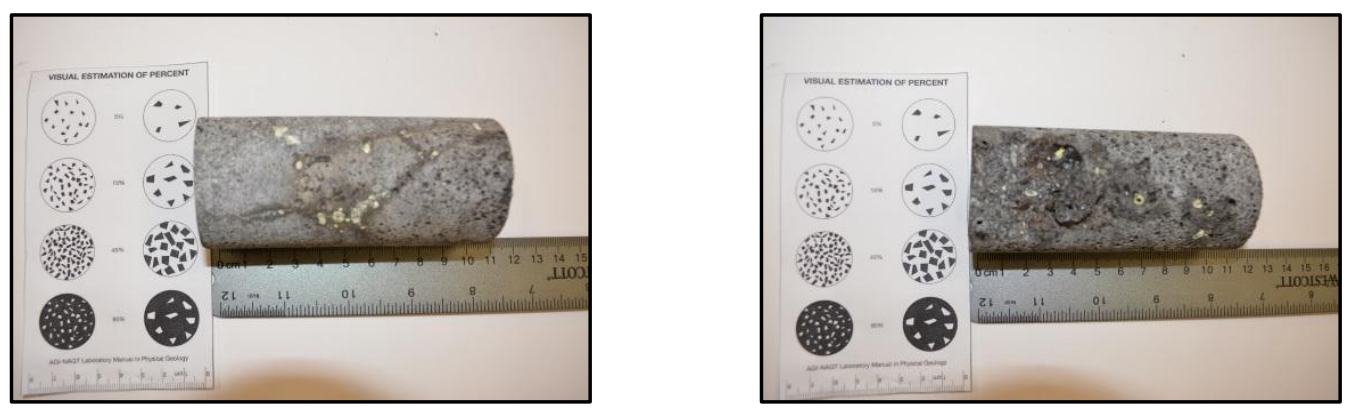
Sample: 5-3-2
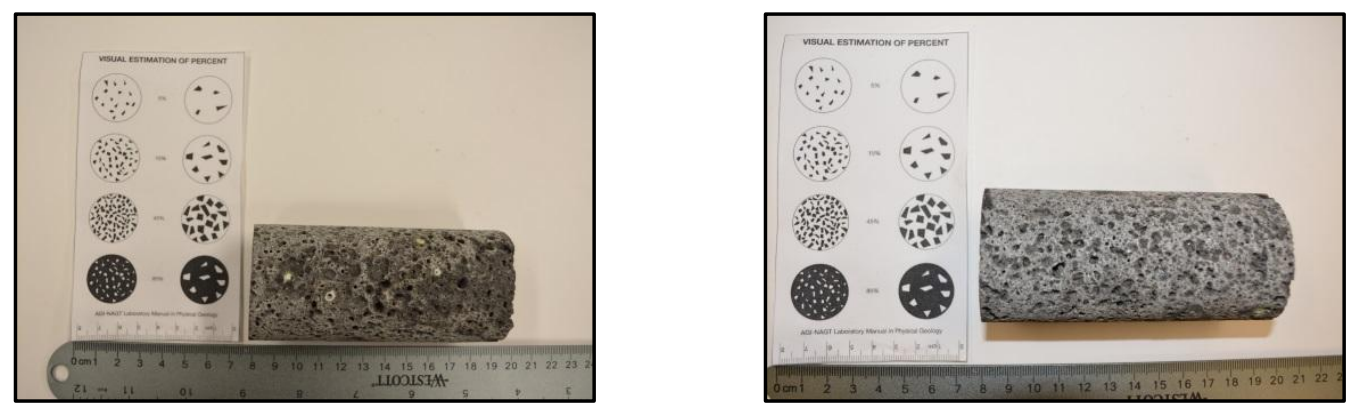

Sample: 5-3-3
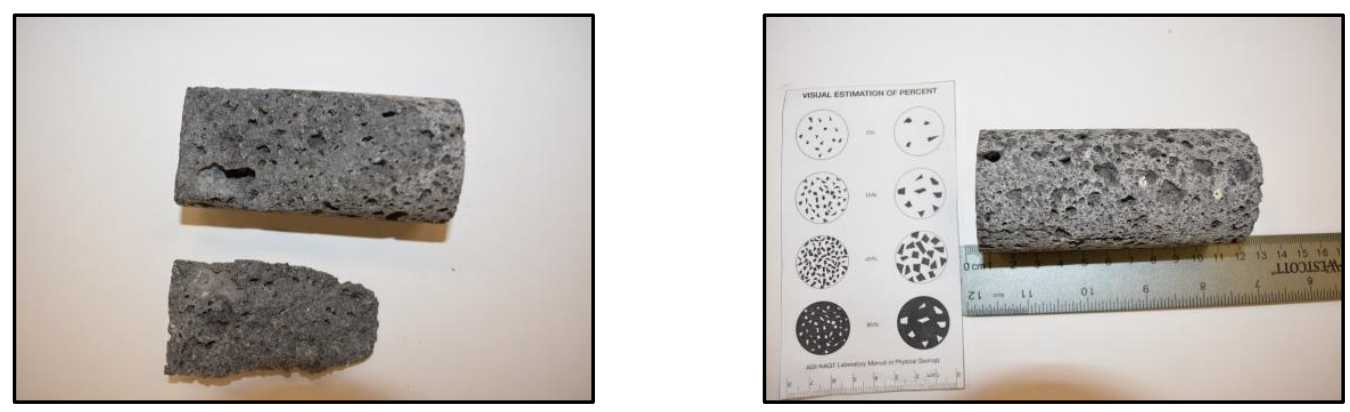

\section{Rock Type 6: Jacobsville Sandstone}

Twelve cores of Jacobsville Sandstone from the Upper Peninsula of Michigan were used and can be seen below in Figure A-7. This sandstone has a unique mottled coloration that consists of a rust brown color with creamy white discoloration. All samples used in this testing had minimal (less than 10\%) white coloration and were mainly rusty red in color. The white spots were normally less than $5 \mathrm{~mm}$ in diameter. 


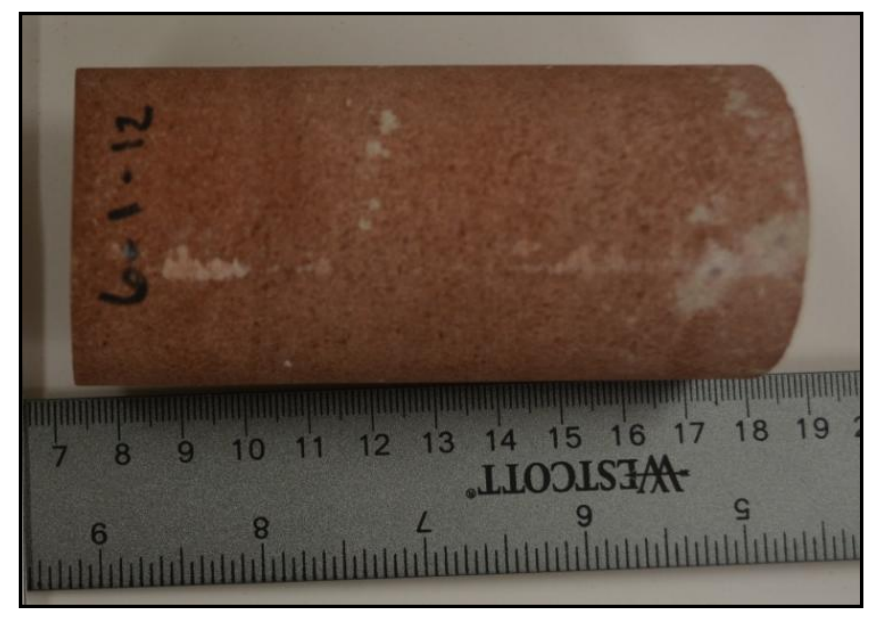

Figure A-7: Sample 6-1-12 of the Jacobsville Sandstone. Note two colors visible on the sample

The sandstone was very uniformly graded with the average particle size being at or around 1 $\mathrm{mm}$ well within the size range for sand size particles. Grains themselves appeared to be rounded and the surface had many small (less than $1 \mathrm{~mm}$ in diameter) voids. This sandstone had a rough texture and felt relatively lightweight for its size. Another thing to note about this material is that it is incredibly permeable which made some testing very difficult as a large amount of water could easily infiltrate into the pores.

Sample: 6-1-1
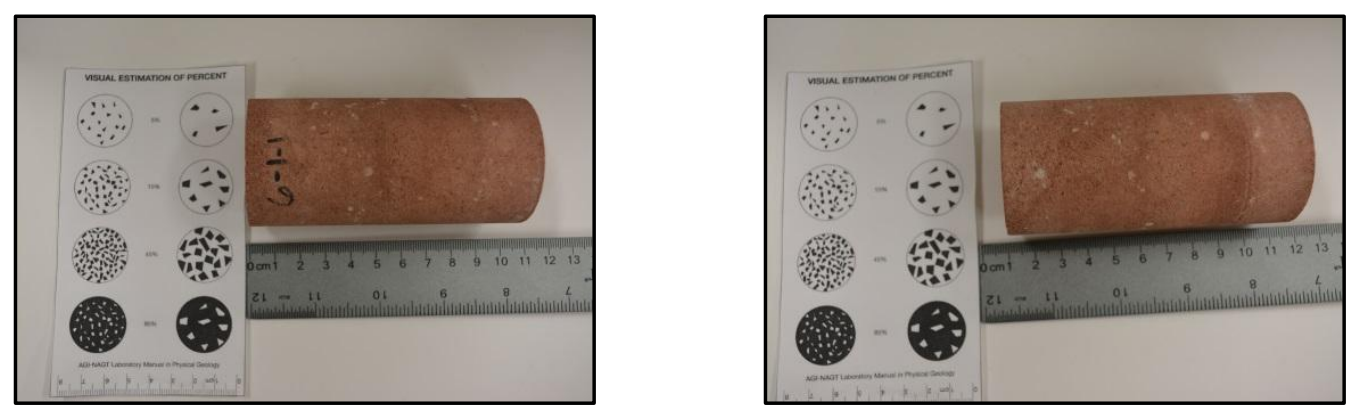
Sample: 6-1-2
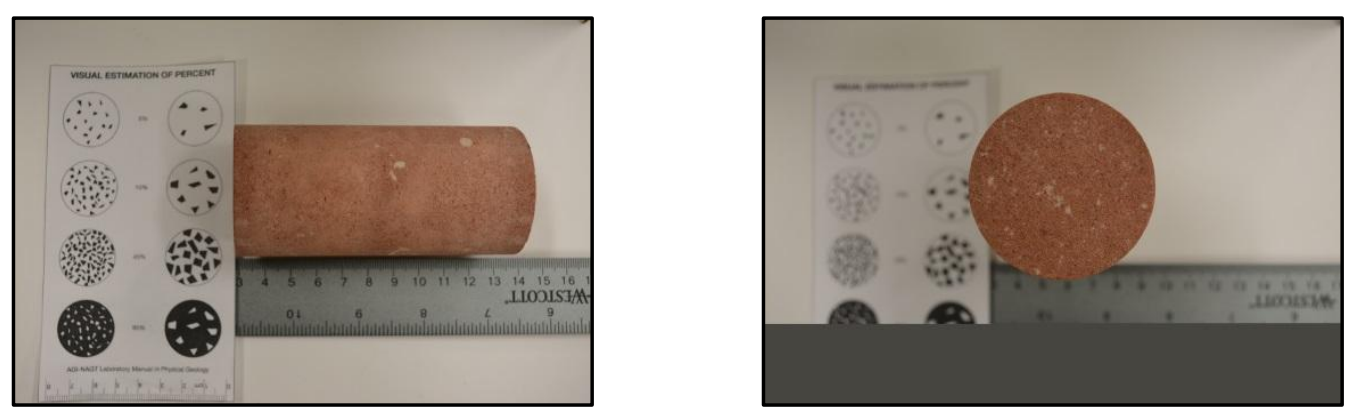

Sample: 6-1-3
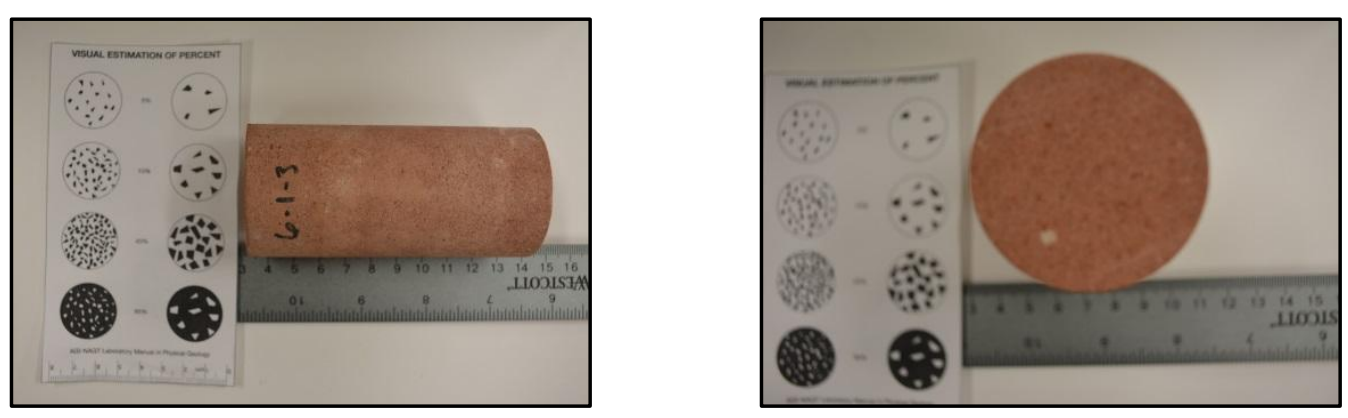

Sample: 6-1-4
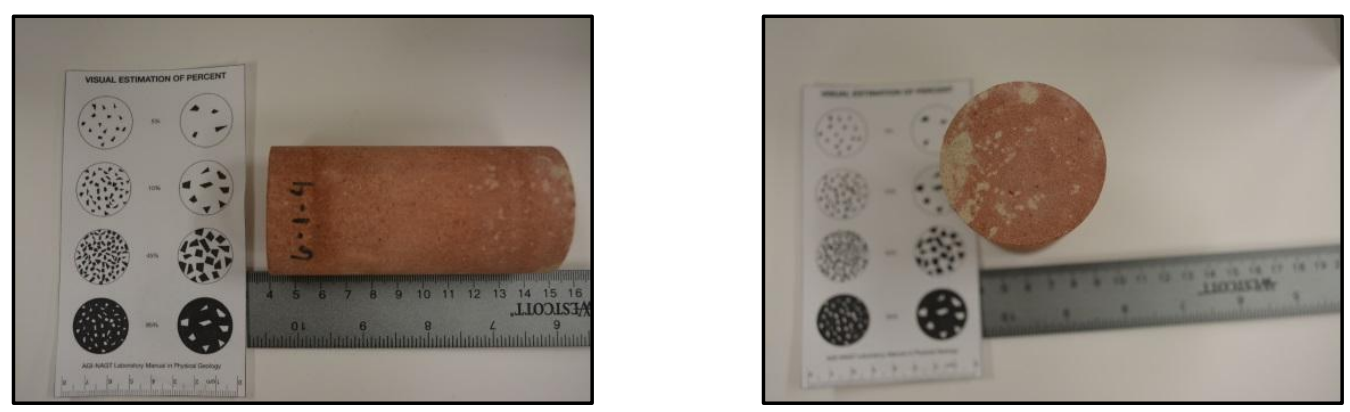
Sample: 6-1-5
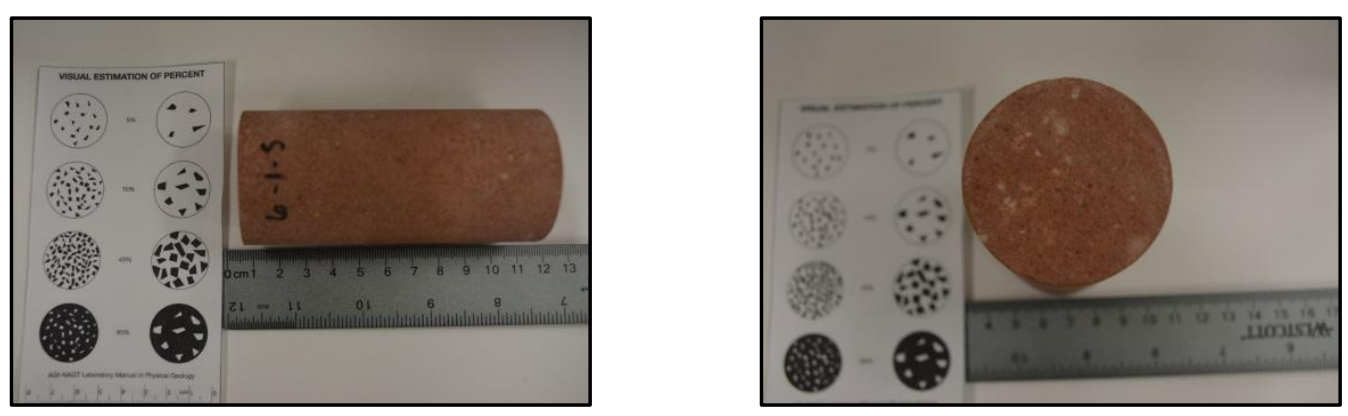

Sample: 6-1-6
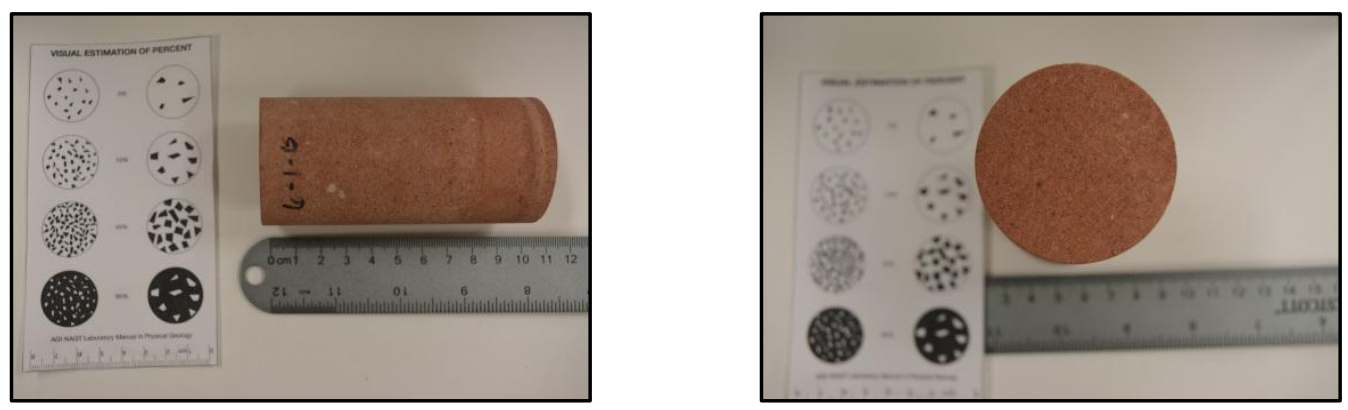

Sample: 6-1-7
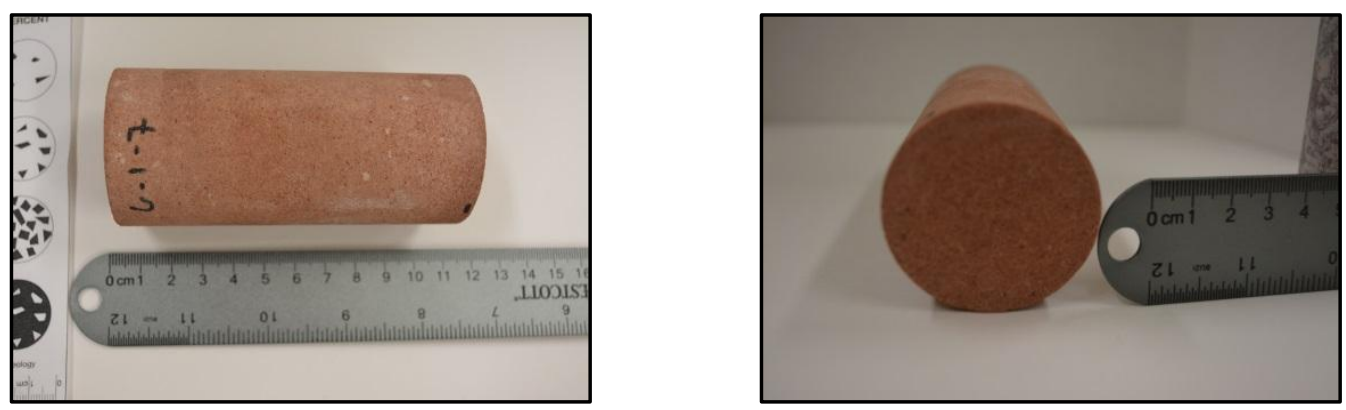
Sample: 6-1-8
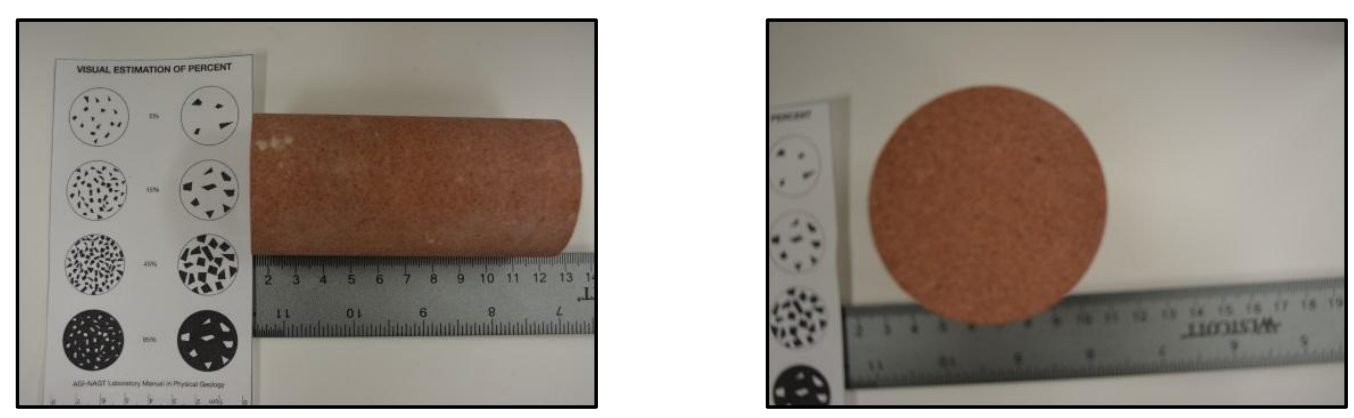

Sample: 6-1-9
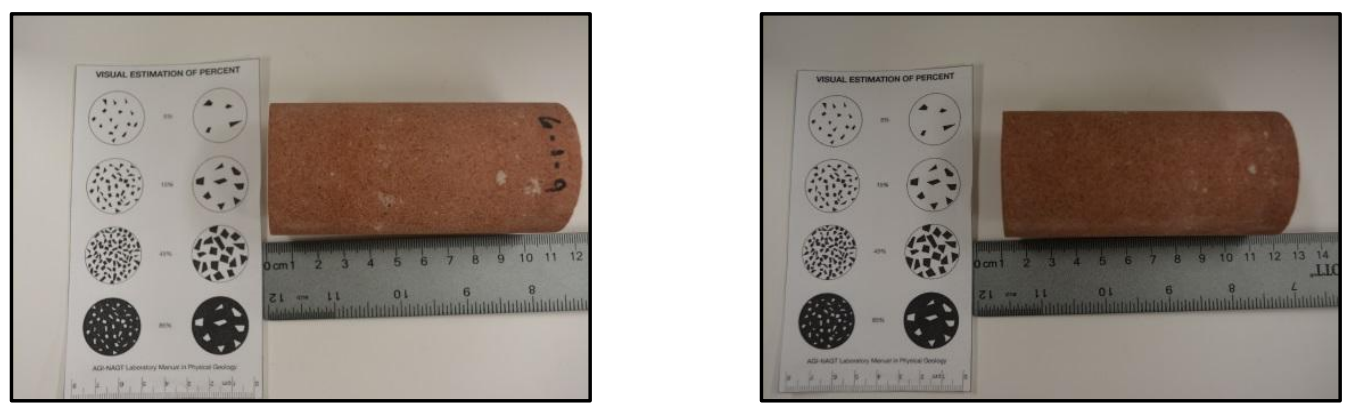

Sample: 6-1-10
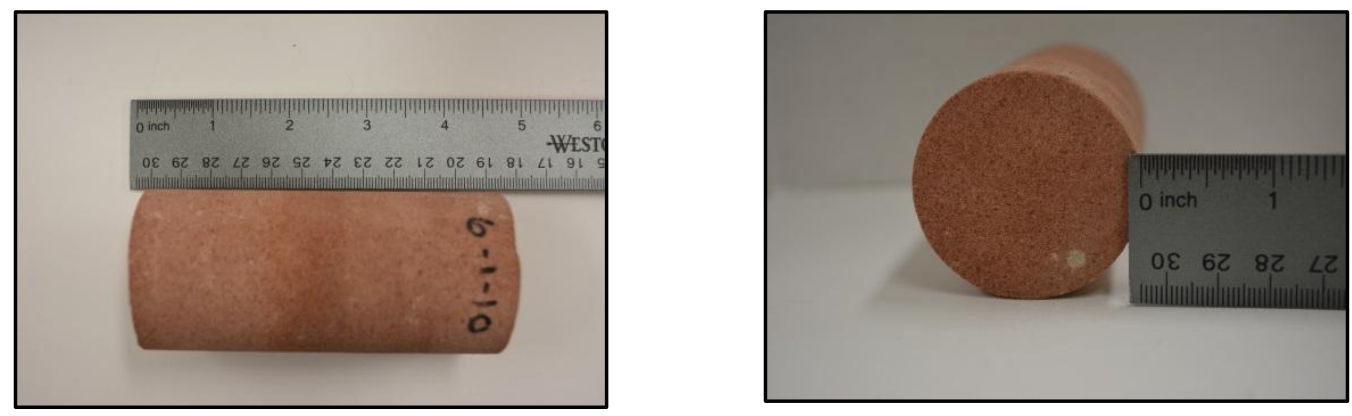
Sample: 6-1-11
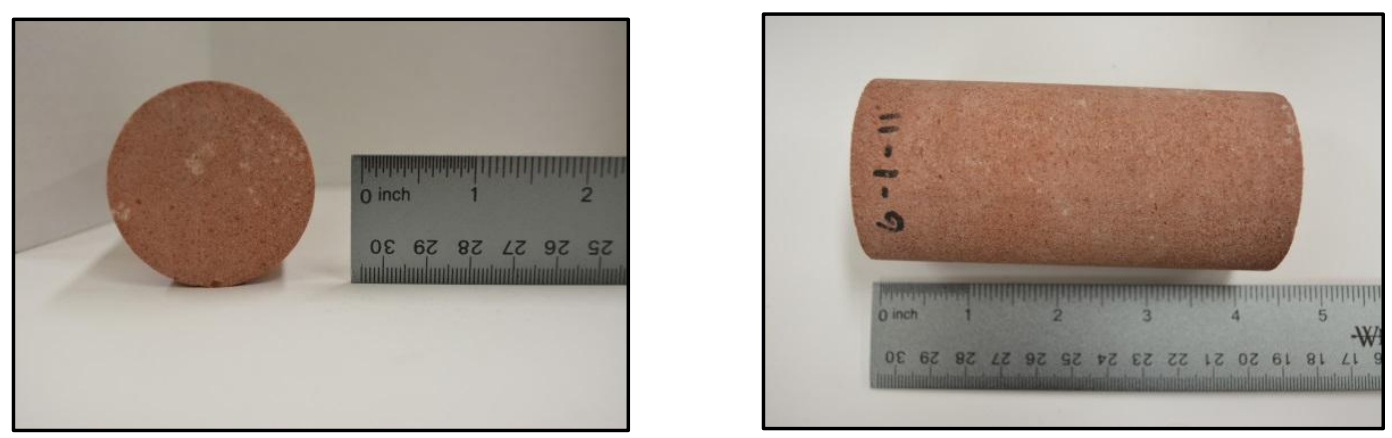

Sample: 6-1-12
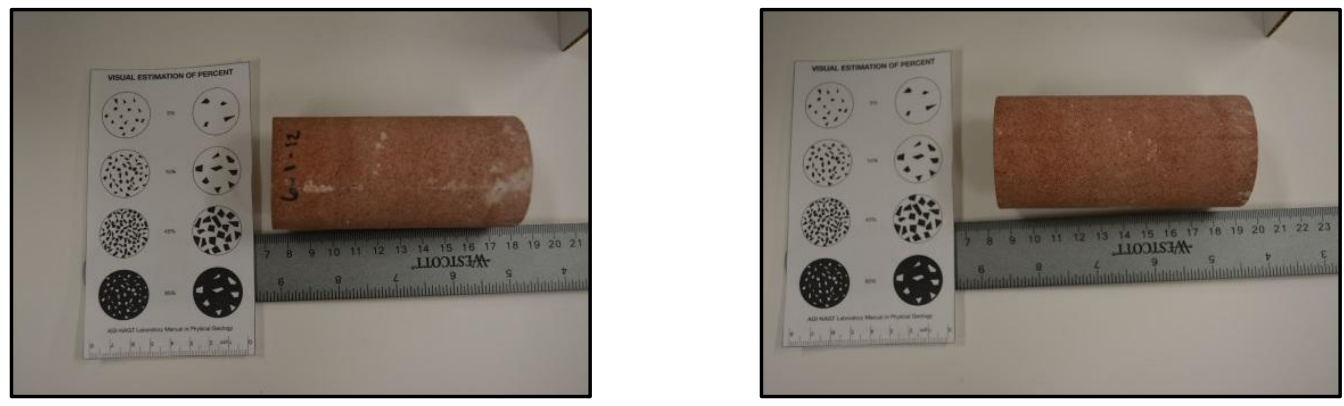

\section{Rock Type 7: Air Cooled Slag}

This blast slag differed in appearance from Rock Type 5. Whereas the previous slag was water cooled this slag was air cooled, so in this case after the pig iron was removed from the furnace instead of placing the slag into a trench to cool and pouring water on it the slag was transported still hot to a pile near the furnace. There it was poured on top of the pile where the still molten slag ran down the sides of the pile and was allowed to cool. Cooling rates between both the air cooling and water cooling methods appear to be about the same however the crystal structure of the rock is different (S. J. Vitton, Subhash,G., Dewey, G., 2002). 
As visible in Figure A-8, these samples at times formed longer more needles like crystals. This may have been a result of the mixing that occurred during transport to the pile or from chemical differences in the slag itself. These longer more oblong crystals caused these slag samples to have pores that were shallower but also had a larger surface area. Some of these crystals could be upwards of a centimeter long and four millimeters wide. Of note is that some samples contained very pronounced oblong crystals but others had a more classic circular pore as seen in the Water Cooled Slag, and example of this can be seen in Figure A-8 below.

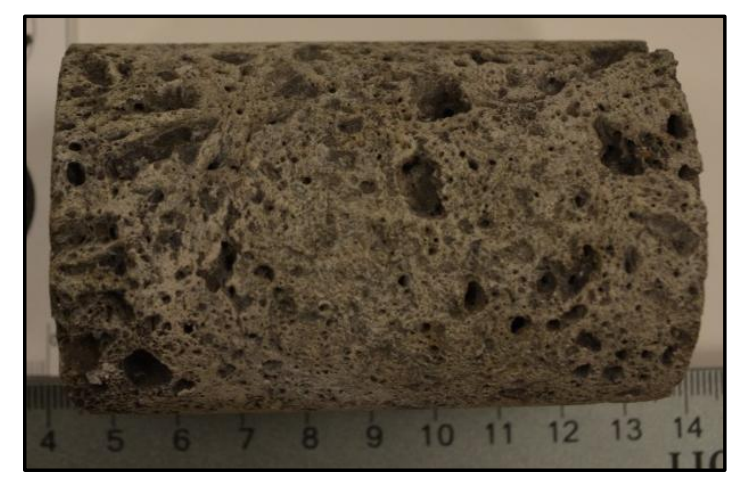

Figure A-8: Sample 7-4 of the Algoma Blast Slag notice the longer crystals and lighter surface coloration

Also visible in both styles of this rock type is the visible "glass" in the bottom of the pores. These visible, dark crystals reflect light and appear to coat the interior of most of the pores. Coloration on these samples is a very light grey with moderate brown staining on the outer surface and a dark grey almost black on the inside of the pores.

Eight samples of Air Cooled Slag were utilized during testing.

\section{Sample: 7-1}
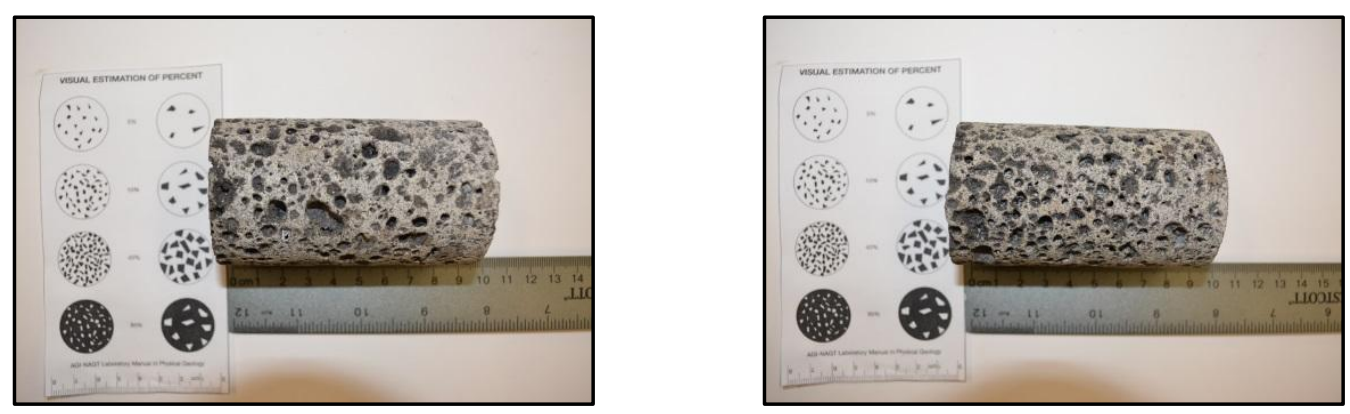
Sample: 7-2
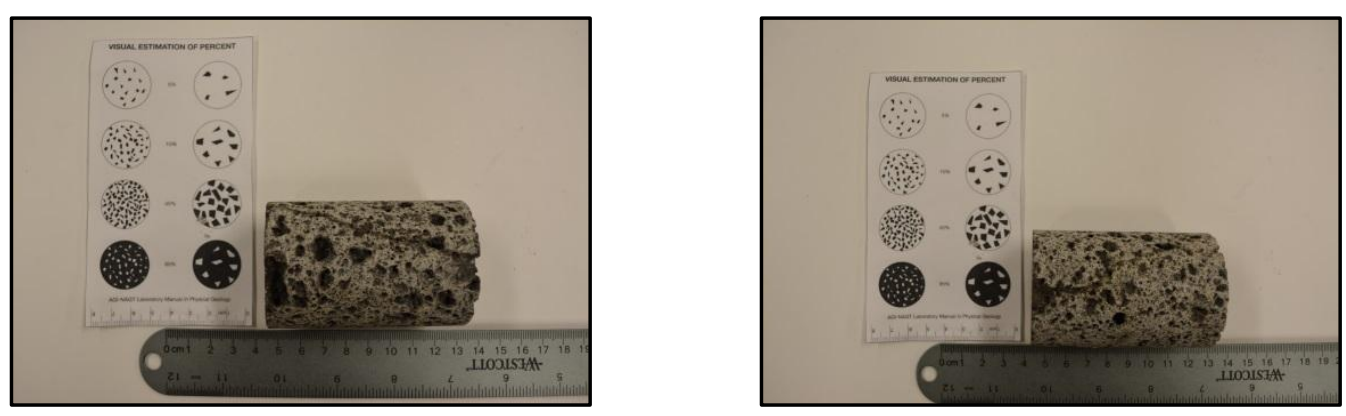

Sample: 7-3
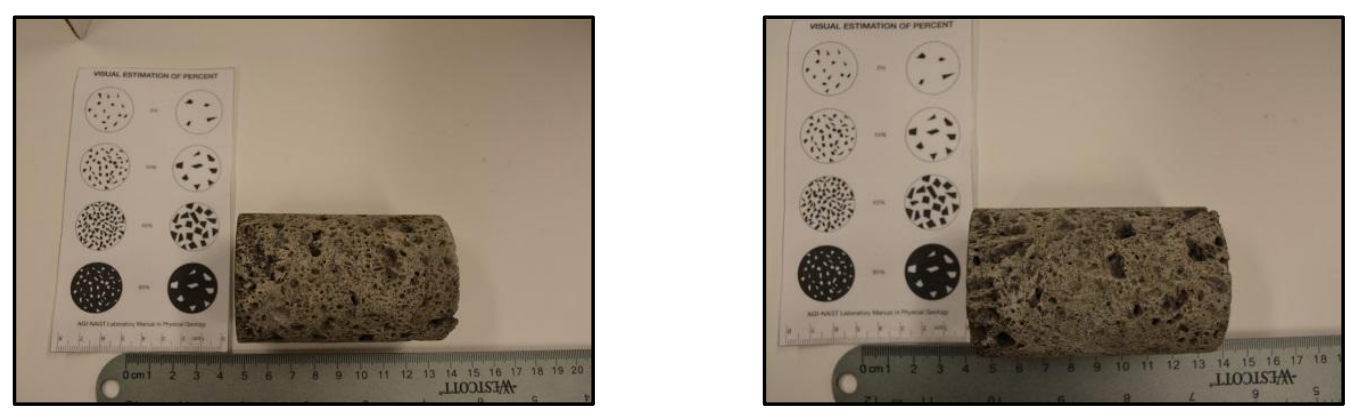

Sample: 7-4
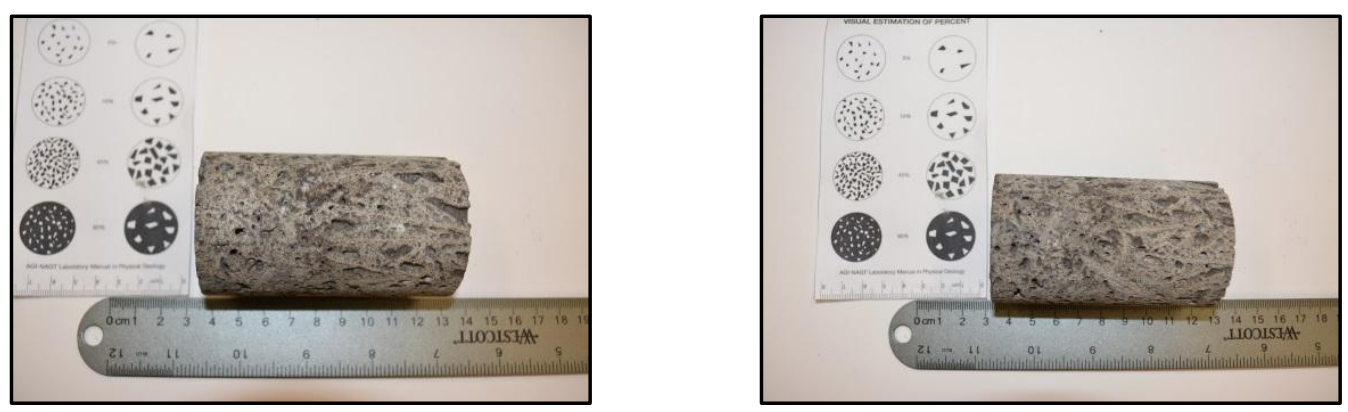
Sample: 7-5
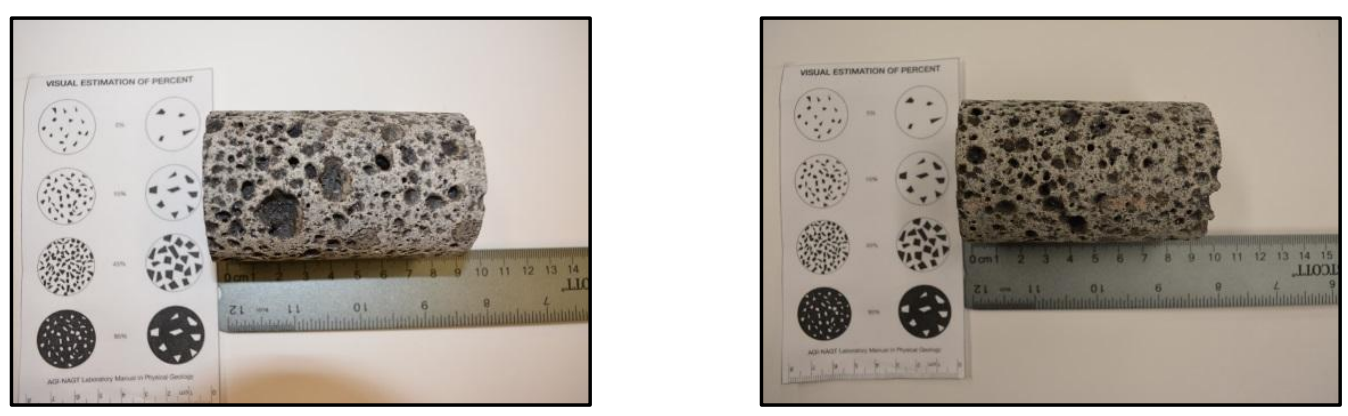

Sample: 7-6
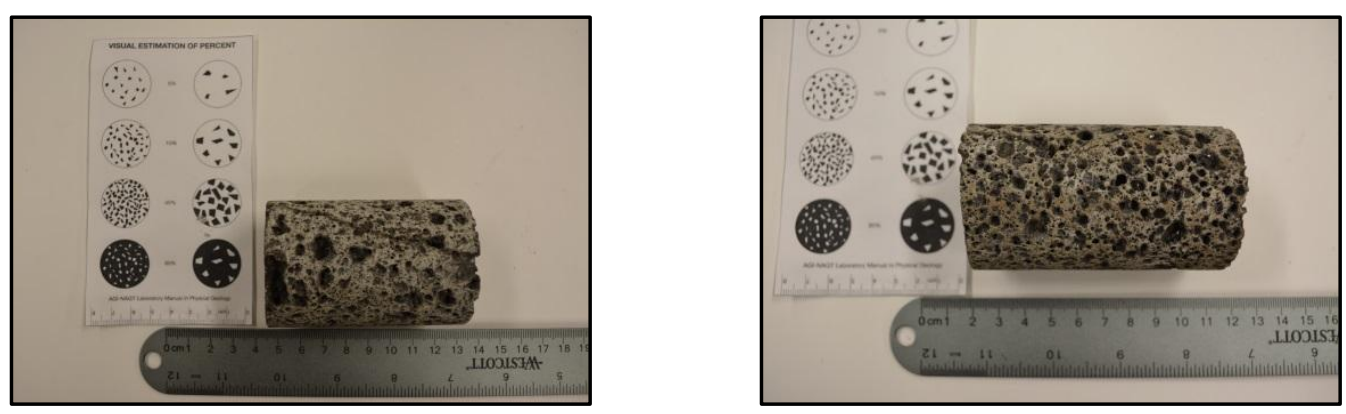

Sample: 7-7
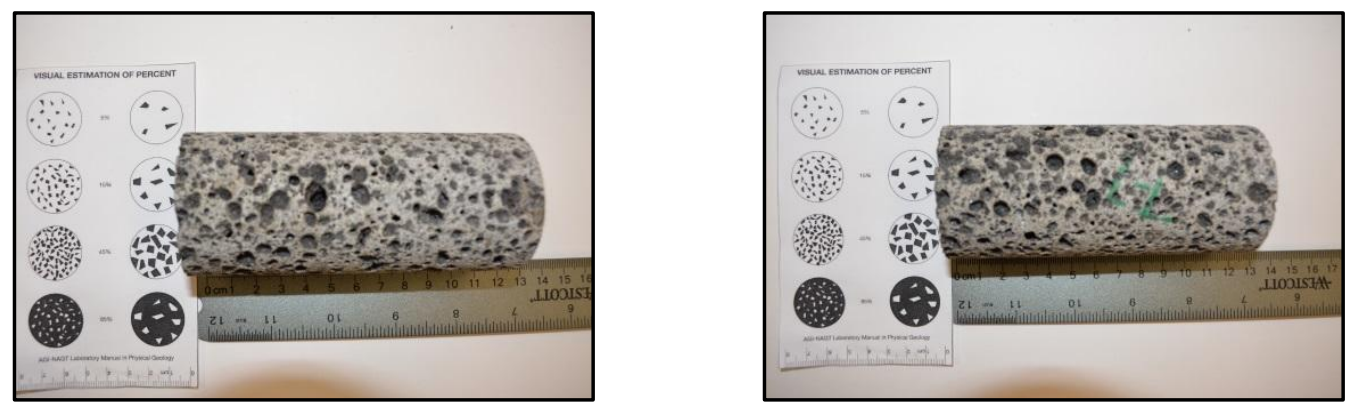
Sample: 7-8
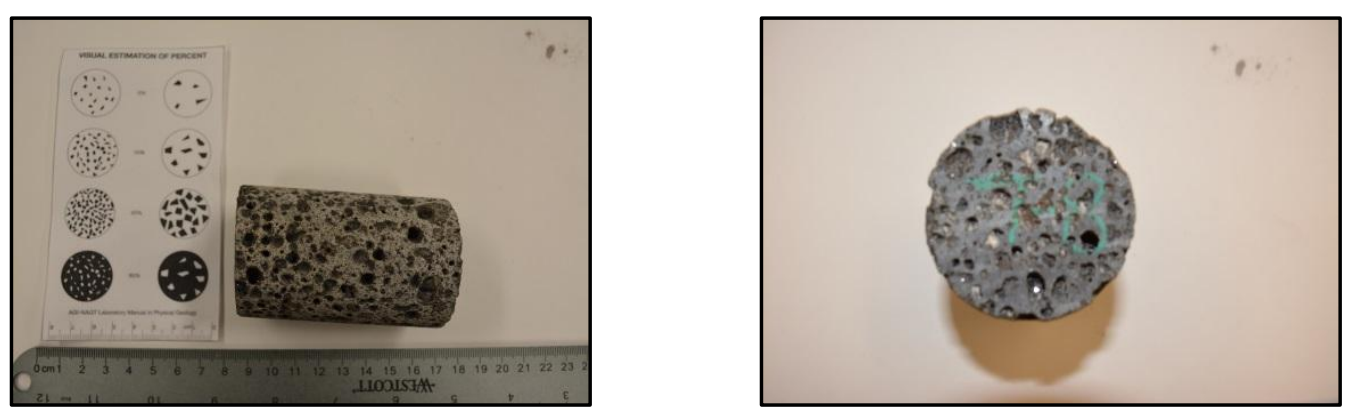


\section{Appendix B: Caliper Results and Procedures}

One of the most basic methods for the determination of bulk density is the Caliper method. While this method is not a common method used today due to its limitations, it is still applicable in some areas. The equipment needs are minimal, only really requiring a balance and caliper.

There are many advantages to this method, one being that the calculations involved are relatively simple. The only information needed, is the length and diameter of the core and it's weight. Another advantage is that the equipment needed to complete these measurements is relatively inexpensive, simple to use, and require, minimal extra training. The final advantage to this method is that the caliper method will not cause any permanent damage to the core. This advantage allows the caliper method to be used to check other methods for density determination, as well make it possible to re-check samples for QA/QC reasons.

There are, however, several major drawbacks to this method as well. The main limitation is that the core needs to be cut into a geometric shape, in order for the volume calculations to work. While achieving a cylinder is relatively easy for competent core, if the rock is fractured or in very angular pieces this can be very difficult to achieve. It can also be difficult to accurately represent an aggregate as a cylindrical core.

A Folder Caliper was used for this testing that was capable of measuring to 0.01 millimeters. In order to maintain accuracy, prior to testing, the calibration of the caliper was checked through calibration blocks. These blocks were used after every fifth sample being tested. To further minimize errors, and account for any variation in the diameter or length of the core, the values that were used for the length and diameter calculations were the mean of four measurements.

The measurement process to determine the length and diameter of the sample is shown in the Figure A-1 below. The portion marked (a) is a schematic of how the length was determined, and the portion marked (b) is for the determination of the diameter. During the measurement process, care was taken to ensure that the caliper was held perpendicular to the core at all times in order to obtain the most accurate measurement possible. 


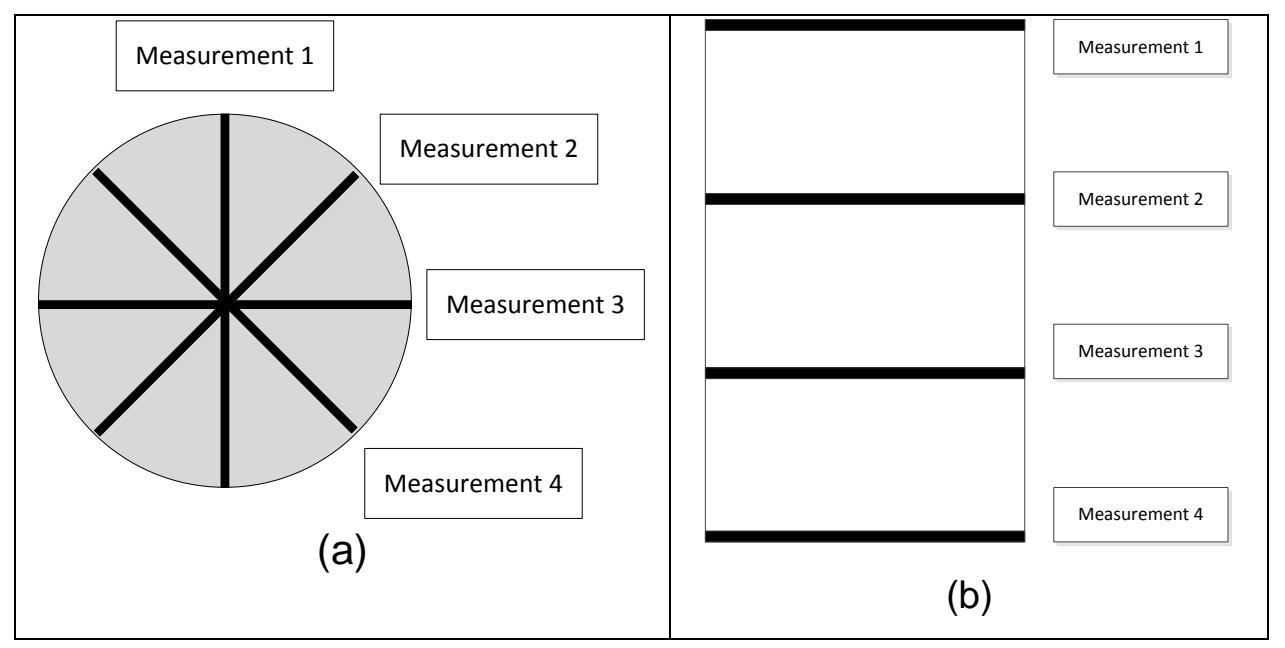

Average length as shown above was the average of four measurements that were taken after a forty five degree rotation of the core.

Average diameter was determined through a similar pattern. The first measurement started at the top of the core sample, and then the core was rotated a quarter turn and dropped 1/3 the length of the core. This process was repeated to obtain the remaining measurements. This was done to account for any variability in the diameter of the core due to the coring process.

Mass of the core was determined using a Meitler Toledo scale which was capable of measuring out to 0.01 grams. Prior to the start of any testing the scales calibration was checked, and throughout testing, calibration weights were used to ensure that the scale was not drifting. To help ensure accurate measurements, and minimize any impacts from air currents, a shield made of Plexiglas was placed around the scale.

The first step in the determination of the bulk density of the cores was to determine the volume of the sample. During this testing, the volume was determined through the equation for the volume of a cylinder. This is shown in the equation below.

$$
V=\frac{\pi * L * D^{2}}{4}
$$

Where:

$$
\begin{aligned}
& V=\text { Volume of the Sample } \\
& D=\text { Average Diameter of the Sample } \\
& L=\text { Average Length of the Sample }
\end{aligned}
$$


The bulk density of the sample was then calculated by dividing the dry weight of the sample (W) by the volume $(\mathrm{V})$ of the sample.

$$
G_{B}=\frac{W}{V}
$$

Where:

$$
\begin{aligned}
& G_{B}=\text { Bulk density of the sample in } \mathrm{g} / \mathrm{cm}^{3} \\
& W=\text { Weight of sample in } \mathrm{g} \\
& V=\text { Volume of Sample in } \mathrm{cm}^{3}
\end{aligned}
$$

To ensure that all measurements were accurate, $25 \%$ of the core samples were re-tested using the caliper method. New average diameters and lengths were determined and the bulk density was recalculated. The two calculated densities were then compared to identify any difference in densities.

Outlined below is the full procedure, and data collected, during this method.

Procedure:

1. Dry the sample for a period of 24 hours \pm 4 hours in an oven set at $110^{\circ} \mathrm{C}$

2. Allow samples to cool to room temperature for at least 3 hours

3. Determine the dry weight ( $\mathrm{W}$ of the sample) prior to any testing

4. Take four measurements to determine the diameter of the sample.

a. Make sure to rotate the core about $90^{\circ}$ between each measurement

b. Move the Caliper about $1 / 3$ the length of the core each time

c. Keep the Caliper parallel to the table with each measurement

5. Take four measurements to determine the diameter of the sample

a. Rotate the core $45^{\circ}$ between each measurement

b. Keep the caliper perpendicular to the core during each measurement

6. Determine the volume of the cylinder

$$
V=\frac{\pi * L * D^{2}}{4}
$$

Where:

$$
\begin{aligned}
& V=\text { Volume of the Sample } \\
& D=\text { Diameter of the Sample } \\
& L=\text { Length of the Sample }
\end{aligned}
$$


7. Determine the density of the cylinder

$$
G_{B}=\frac{W}{V}
$$

Where:

$\mathrm{G}_{\mathrm{B}}=$ Bulk density of the sample in $\mathrm{g} / \mathrm{cm}^{3}$

$\mathrm{W}=$ Weight of sample in $\mathrm{g}$

$\mathrm{V}=$ Volume of Sample in $\mathrm{cm}^{3}$ 
Table B.1: Dimension determination for the Caliper Method for Rock Type 1: Granite

\begin{tabular}{|c|c|c|c|c|c|c|}
\hline $\begin{array}{c}\text { Sample } \\
\text { ID }\end{array}$ & $\begin{array}{l}\text { Diameter } \\
(\mathrm{mm})\end{array}$ & $\begin{array}{l}\text { Diameter } \\
(\mathrm{cm})\end{array}$ & $\begin{array}{c}\text { Average } \\
\text { Diameter } \\
(\mathrm{cm})\end{array}$ & $\begin{array}{l}\text { Length } \\
(\mathrm{mm})\end{array}$ & $\begin{array}{l}\text { Length } \\
\text { (cm) }\end{array}$ & $\begin{array}{c}\text { Average } \\
\text { Length }(\mathrm{cm})\end{array}$ \\
\hline \multirow{4}{*}{$1-1-1$} & 47.51 & 4.75 & \multirow{4}{*}{4.75} & 151.55 & 15.16 & \multirow{4}{*}{15.16} \\
\hline & 47.49 & 4.75 & & 151.84 & 15.18 & \\
\hline & 47.43 & 4.74 & & 151.50 & 15.15 & \\
\hline & 47.46 & 4.75 & & 151.55 & 15.16 & \\
\hline \multirow{4}{*}{$1-1-2$} & 47.68 & 4.77 & \multirow{4}{*}{4.76} & 100.97 & 10.10 & \multirow{4}{*}{10.06} \\
\hline & 47.78 & 4.78 & & 100.64 & 10.06 & \\
\hline & 47.43 & 4.74 & & 100.14 & 10.01 & \\
\hline & 47.41 & 4.74 & & 100.72 & 10.07 & \\
\hline \multirow{4}{*}{$1-1-4$} & 47.46 & 4.75 & \multirow{4}{*}{4.75} & 97.31 & 9.73 & \multirow{4}{*}{9.63} \\
\hline & 47.48 & 4.75 & & 96.26 & 9.63 & \\
\hline & 47.43 & 4.74 & & 95.87 & 9.59 & \\
\hline & 47.47 & 4.75 & & 95.93 & 9.59 & \\
\hline
\end{tabular}

Table B.2: Final bulk density values for the Caliper Method for Rock Type 1: Granite

\begin{tabular}{|c|c|c|c|}
\hline Sample ID & Volume $\left(\mathrm{cm}^{\wedge} 3\right)$ & Weight $(\mathrm{g})$ & Density $\left(\mathrm{g} / \mathrm{cm}^{\wedge} 3\right)$ \\
\hline $1-1-1$ & 268.35 & 704.05 & 2.62 \\
\hline $1-1-2$ & 178.86 & 466.36 & 2.61 \\
\hline $1-1-4$ & 170.44 & 444.12 & 2.61 \\
\hline
\end{tabular}

Table B.3: Dimension determination for the Caliper Method for Rock Type 2: Kona Dolomite

\begin{tabular}{|c|c|c|c|c|c|c|}
\hline $\begin{array}{c}\text { Sample } \\
\text { ID }\end{array}$ & $\begin{array}{l}\text { Diameter } \\
(\mathrm{mm})\end{array}$ & $\begin{array}{c}\text { Diameter } \\
(\mathrm{cm})\end{array}$ & $\begin{array}{c}\text { Average } \\
\text { Diameter } \\
(\mathrm{cm})\end{array}$ & $\begin{array}{c}\text { Length } \\
(\mathrm{mm})\end{array}$ & $\begin{array}{l}\text { Length } \\
(\mathrm{cm})\end{array}$ & $\begin{array}{c}\text { Average } \\
\text { Length }(\mathrm{cm})\end{array}$ \\
\hline \multirow{4}{*}{$2-1-1$} & 47.57 & 4.76 & \multirow{4}{*}{4.75} & 107.81 & 10.78 & \multirow{4}{*}{10.79} \\
\hline & 47.45 & 4.75 & & 108.00 & 10.80 & \\
\hline & 47.45 & 4.75 & & 107.84 & 10.78 & \\
\hline & 47.62 & 4.76 & & 107.92 & 10.79 & \\
\hline \multirow{4}{*}{$2-1-2$} & 47.21 & 4.72 & \multirow{4}{*}{4.74} & 104.46 & 10.45 & \multirow{4}{*}{10.46} \\
\hline & 47.29 & 4.73 & & 104.70 & 10.47 & \\
\hline & 47.53 & 4.75 & & 104.63 & 10.46 & \\
\hline & 47.61 & 4.76 & & 104.41 & 10.44 & \\
\hline
\end{tabular}




\begin{tabular}{|c|c|c|c|c|c|c|}
\hline $\begin{array}{c}\text { Sample } \\
\text { ID }\end{array}$ & $\begin{array}{l}\text { Diameter } \\
(\mathrm{mm})\end{array}$ & $\begin{array}{l}\text { Diameter } \\
(\mathrm{cm})\end{array}$ & $\begin{array}{c}\text { Average } \\
\text { Diameter } \\
(\mathrm{cm})\end{array}$ & $\begin{array}{c}\text { Length } \\
(\mathrm{mm})\end{array}$ & $\begin{array}{l}\text { Length } \\
\text { (cm) }\end{array}$ & $\begin{array}{c}\text { Average } \\
\text { Length }(\mathrm{cm})\end{array}$ \\
\hline \multirow{4}{*}{$2-1-3$} & 47.27 & 4.73 & \multirow{4}{*}{4.73} & 106.12 & 10.61 & \multirow{4}{*}{10.65} \\
\hline & 47.51 & 4.75 & & 106.36 & 10.64 & \\
\hline & 47.27 & 4.73 & & 106.51 & 10.65 & \\
\hline & 47.28 & 4.73 & & 106.91 & 10.69 & \\
\hline \multirow{4}{*}{$2-1-4$} & 47.36 & 4.74 & \multirow{4}{*}{4.74} & 108.01 & 10.80 & \multirow{4}{*}{10.80} \\
\hline & 47.39 & 4.74 & & 107.90 & 10.79 & \\
\hline & 47.40 & 4.74 & & 108.29 & 10.83 & \\
\hline & 47.48 & 4.75 & & 107.80 & 10.78 & \\
\hline \multirow{4}{*}{$2-2-1$} & 47.53 & 4.75 & \multirow{4}{*}{4.76} & 106.51 & 10.65 & \multirow{4}{*}{10.65} \\
\hline & 47.67 & 4.77 & & 106.58 & 10.66 & \\
\hline & 47.63 & 4.76 & & 106.52 & 10.65 & \\
\hline & 47.58 & 4.76 & & 106.47 & 10.65 & \\
\hline \multirow{4}{*}{$2-2-2$} & 47.43 & 4.74 & \multirow{4}{*}{4.75} & 106.68 & 10.67 & \multirow{4}{*}{10.66} \\
\hline & 47.57 & 4.76 & & 106.46 & 10.65 & \\
\hline & 47.48 & 4.75 & & 106.71 & 10.67 & \\
\hline & 47.42 & 4.74 & & 106.58 & 10.66 & \\
\hline \multirow{4}{*}{$2-2-3$} & 47.60 & 4.76 & \multirow{4}{*}{4.75} & 106.03 & 10.60 & \multirow{4}{*}{10.61} \\
\hline & 47.45 & 4.75 & & 105.74 & 10.57 & \\
\hline & 47.45 & 4.75 & & 106.52 & 10.65 & \\
\hline & 47.42 & 4.74 & & 105.92 & 10.59 & \\
\hline \multirow{4}{*}{$2-2-4$} & 46.49 & 4.65 & \multirow{4}{*}{4.66} & 104.41 & 10.44 & \multirow{4}{*}{10.44} \\
\hline & 46.75 & 4.68 & & 104.30 & 10.43 & \\
\hline & 46.77 & 4.68 & & 104.44 & 10.44 & \\
\hline & 46.46 & 4.65 & & 104.33 & 10.43 & \\
\hline \multirow{4}{*}{$2-2-5$} & 46.67 & 4.67 & \multirow{4}{*}{4.68} & 103.13 & 10.31 & \multirow{4}{*}{10.32} \\
\hline & 47.06 & 4.71 & & 103.19 & 10.32 & \\
\hline & 46.59 & 4.66 & & 103.31 & 10.33 & \\
\hline & 46.82 & 4.68 & & 103.31 & 10.33 & \\
\hline \multirow{4}{*}{$2-2-6$} & 47.65 & 4.77 & \multirow{4}{*}{4.76} & 108.35 & 10.84 & \multirow{4}{*}{10.87} \\
\hline & 47.82 & 4.78 & & 109.36 & 10.94 & \\
\hline & 47.59 & 4.76 & & 107.71 & 10.77 & \\
\hline & 47.53 & 4.75 & & 109.22 & 10.92 & \\
\hline
\end{tabular}


Table B.4: Final Bulk Density values for the Caliper Method for Rock Type 2: Kona Dolomite

\begin{tabular}{|c|c|c|c|}
\hline Sample ID & Volume $\left(\mathrm{cm}^{\wedge} 3\right)$ & Weight $(\mathrm{g})$ & Density $\left(\mathrm{g} / \mathrm{cm}^{\wedge} 3\right)$ \\
\hline $2-1-1$ & 191.37 & 508.47 & 2.66 \\
\hline $2-1-2$ & 184.57 & 490.99 & 2.66 \\
\hline $2-1-3$ & 187.35 & 510.8 & 2.73 \\
\hline $2-1-4$ & 190.64 & 511.94 & 2.69 \\
\hline $2-2-1$ & 189.57 & 536.02 & 2.83 \\
\hline $2-2-2$ & 188.72 & 518.23 & 2.75 \\
\hline $2-2-3$ & 187.77 & 532.22 & 2.83 \\
\hline $2-2-4$ & 178.14 & 502.83 & 2.82 \\
\hline $2-2-5$ & 177.47 & 502.02 & 2.83 \\
\hline $2-2-6$ & 193.75 & 505.31 & 2.61 \\
\hline
\end{tabular}

Table B.5: Dimension determination for the Caliper Method for Rock Type 3: Pelkie Dolomite

\begin{tabular}{|c|c|c|c|c|c|c|}
\hline $\begin{array}{c}\text { Sample } \\
\text { ID }\end{array}$ & $\begin{array}{l}\text { Diameter } \\
(\mathrm{mm})\end{array}$ & $\begin{array}{l}\text { Diameter } \\
(\mathrm{cm})\end{array}$ & $\begin{array}{c}\text { Average } \\
\text { Diameter } \\
(\mathrm{cm})\end{array}$ & $\begin{array}{c}\text { Length } \\
(\mathrm{mm})\end{array}$ & $\begin{array}{l}\text { Length } \\
\text { (cm) }\end{array}$ & $\begin{array}{c}\text { Average } \\
\text { Length }(\mathrm{cm})\end{array}$ \\
\hline \multirow{4}{*}{$3-2-1$} & 47.18 & 4.72 & \multirow{4}{*}{4.73} & 54.98 & 5.50 & \multirow{4}{*}{5.49} \\
\hline & 47.23 & 4.72 & & 54.96 & 5.50 & \\
\hline & 47.41 & 4.74 & & 55.01 & 5.50 & \\
\hline & 47.44 & 4.74 & & 54.75 & 5.48 & \\
\hline \multirow{4}{*}{$3-3-1$} & 47.05 & 7.22 & \multirow{4}{*}{7.20} & 72.15 & 4.71 & \multirow{4}{*}{4.71} \\
\hline & 47.08 & 7.17 & & 71.65 & 4.71 & \\
\hline & 47.03 & 7.19 & & 71.88 & 4.70 & \\
\hline & 47.05 & 7.22 & & 72.18 & 4.71 & \\
\hline
\end{tabular}

Table B.6: Final bulk density values for the Caliper Method for Rock Type 3: Pelkie Dolomite

\begin{tabular}{|l|r|r|r|}
\hline \multicolumn{1}{|c|}{ Sample ID } & Volume $\left(\mathrm{cm}^{\wedge} 3\right)$ & Weight $(\mathrm{g})$ & Density $\left(\mathrm{g} / \mathrm{cm}^{\wedge} 3\right)$ \\
\hline $3-2-1$ & 96.47 & 257.71 & 2.67 \\
\hline $3-3-1$ & 191.39 & 338.79 & 1.77 \\
\hline
\end{tabular}


Table B.7: Dimension determination for the Caliper Method for Rock Type 4: Various Carbonates

\begin{tabular}{|c|c|c|c|c|c|c|}
\hline $\begin{array}{c}\text { Sample } \\
\text { ID }\end{array}$ & $\begin{array}{l}\text { Diameter } \\
(\mathrm{mm})\end{array}$ & $\begin{array}{c}\text { Diameter } \\
(\mathrm{cm})\end{array}$ & $\begin{array}{c}\text { Average } \\
\text { Diameter } \\
(\mathrm{cm})\end{array}$ & $\begin{array}{c}\text { Length } \\
(\mathrm{mm})\end{array}$ & $\begin{array}{c}\text { Length } \\
(\mathrm{cm})\end{array}$ & $\begin{array}{c}\text { Average } \\
\text { Length }(\mathrm{cm})\end{array}$ \\
\hline \multirow{4}{*}{$4-1-1$} & 47.05 & 4.71 & \multirow{4}{*}{4.72} & 94.68 & 9.47 & \multirow{4}{*}{9.46} \\
\hline & 47.16 & 4.72 & & 94.88 & 9.49 & \\
\hline & 47.09 & 4.71 & & 94.42 & 9.44 & \\
\hline & 47.32 & 4.73 & & 94.45 & 9.45 & \\
\hline \multirow{4}{*}{$4-1-2$} & 47.18 & 4.72 & \multirow{4}{*}{4.71} & 103.37 & 10.34 & \multirow{4}{*}{10.30} \\
\hline & 47.22 & 4.72 & & 103.77 & 10.38 & \\
\hline & 47.09 & 4.71 & & 102.40 & 10.24 & \\
\hline & 47.09 & 4.71 & & 102.33 & 10.23 & \\
\hline \multirow{4}{*}{$4-1-3$} & 46.70 & 4.67 & \multirow{4}{*}{4.67} & 139.76 & 13.98 & \multirow{4}{*}{13.98} \\
\hline & 46.68 & 4.67 & & 139.65 & 13.97 & \\
\hline & 46.89 & 4.69 & & 140.30 & 14.03 & \\
\hline & 46.67 & 4.67 & & 139.61 & 13.96 & \\
\hline \multirow{4}{*}{$4-1-4$} & 46.92 & 4.69 & \multirow{4}{*}{4.69} & 167.65 & 16.77 & \multirow{4}{*}{16.75} \\
\hline & 46.72 & 4.67 & & 167.84 & 16.78 & \\
\hline & 46.92 & 4.69 & & 167.54 & 16.75 & \\
\hline & 46.89 & 4.69 & & 167.10 & 16.71 & \\
\hline \multirow{4}{*}{$4-1-5$} & 46.75 & 4.68 & \multirow{4}{*}{4.70} & 99.00 & 9.90 & \multirow{4}{*}{9.90} \\
\hline & 47.04 & 4.70 & & 98.73 & 9.87 & \\
\hline & 47.00 & 4.70 & & 99.04 & 9.90 & \\
\hline & 47.01 & 4.70 & & 99.23 & 9.92 & \\
\hline \multirow{4}{*}{$4-2-1$} & 45.56 & 4.56 & \multirow{4}{*}{4.57} & 102.40 & 10.24 & \multirow{4}{*}{10.26} \\
\hline & 45.84 & 4.58 & & 102.08 & 10.21 & \\
\hline & 45.56 & 4.56 & & 103.51 & 10.35 & \\
\hline & 45.64 & 4.56 & & 102.54 & 10.25 & \\
\hline \multirow{4}{*}{$4-2-2$} & 46.69 & 4.67 & \multirow{4}{*}{4.68} & 103.21 & 10.32 & \multirow{4}{*}{10.34} \\
\hline & 46.82 & 4.68 & & 103.03 & 10.30 & \\
\hline & 46.89 & 4.69 & & 103.36 & 10.34 & \\
\hline & 46.60 & 4.66 & & 103.80 & 10.38 & \\
\hline \multirow{4}{*}{$4-2-3$} & 46.88 & 4.69 & \multirow{4}{*}{4.69} & 105.79 & 10.58 & \multirow{4}{*}{10.55} \\
\hline & 46.92 & 4.69 & & 105.61 & 10.56 & \\
\hline & 46.87 & 4.69 & & 105.28 & 10.53 & \\
\hline & 46.97 & 4.70 & & 105.29 & 10.53 & \\
\hline
\end{tabular}




\begin{tabular}{|c|c|c|c|c|c|c|}
\hline $\begin{array}{c}\text { Sample } \\
\text { ID }\end{array}$ & $\begin{array}{l}\text { Diameter } \\
(\mathrm{mm})\end{array}$ & $\begin{array}{l}\text { Diameter } \\
(\mathrm{cm})\end{array}$ & $\begin{array}{c}\text { Average } \\
\text { Diameter } \\
(\mathrm{cm})\end{array}$ & $\begin{array}{c}\text { Length } \\
(\mathrm{mm})\end{array}$ & $\begin{array}{l}\text { Length } \\
\text { (cm) }\end{array}$ & $\begin{array}{c}\text { Average } \\
\text { Length }(\mathrm{cm})\end{array}$ \\
\hline \multirow{4}{*}{$4-3-1$} & 46.99 & 4.70 & \multirow{4}{*}{4.69} & 41.08 & 4.11 & \multirow{4}{*}{4.11} \\
\hline & 46.96 & 4.70 & & 41.09 & 4.11 & \\
\hline & 46.81 & 4.68 & & 41.05 & 4.11 & \\
\hline & 46.95 & 4.70 & & 41.06 & 4.11 & \\
\hline \multirow{4}{*}{$4-3-2$} & 47.02 & 4.70 & \multirow{4}{*}{4.70} & 77.64 & 7.76 & \multirow{4}{*}{7.75} \\
\hline & 47.11 & 4.71 & & 77.68 & 7.77 & \\
\hline & 47.13 & 4.71 & & 77.29 & 7.73 & \\
\hline & 46.90 & 4.69 & & 77.40 & 7.74 & \\
\hline \multirow{4}{*}{$4-3-3$} & 47.02 & 4.70 & \multirow{4}{*}{4.71} & 71.76 & 7.18 & \multirow{4}{*}{7.15} \\
\hline & 47.04 & 4.70 & & 71.29 & 7.13 & \\
\hline & 47.09 & 4.71 & & 71.41 & 7.14 & \\
\hline & 47.33 & 4.73 & & 71.62 & 7.16 & \\
\hline \multirow{4}{*}{$4-4-1$} & 47.40 & 4.74 & \multirow{4}{*}{4.74} & 73.35 & 7.34 & \multirow{4}{*}{7.34} \\
\hline & 47.39 & 4.74 & & 73.28 & 7.33 & \\
\hline & 47.40 & 4.74 & & 73.43 & 7.34 & \\
\hline & 47.45 & 4.75 & & 73.42 & 7.34 & \\
\hline \multirow{4}{*}{$4-4-2$} & 47.37 & 4.74 & \multirow{4}{*}{4.74} & 88.88 & 8.89 & \multirow{4}{*}{8.92} \\
\hline & 47.41 & 4.74 & & 89.23 & 8.92 & \\
\hline & 47.37 & 4.74 & & 89.20 & 8.92 & \\
\hline & 47.42 & 4.74 & & 89.44 & 8.94 & \\
\hline \multirow{4}{*}{$4-4-3$} & 47.46 & 4.75 & \multirow{4}{*}{4.74} & 81.51 & 8.15 & \multirow{4}{*}{8.16} \\
\hline & 47.42 & 4.74 & & 81.52 & 8.15 & \\
\hline & 47.26 & 4.73 & & 81.66 & 8.17 & \\
\hline & 47.43 & 4.74 & & 81.53 & 8.15 & \\
\hline \multirow{4}{*}{$4-5-1$} & 46.95 & 4.70 & \multirow{4}{*}{4.68} & 130.29 & 13.03 & \multirow{4}{*}{13.05} \\
\hline & 46.78 & 4.68 & & 130.44 & 13.04 & \\
\hline & 46.64 & 4.66 & & 130.99 & 13.10 & \\
\hline & 46.85 & 4.69 & & 130.26 & 13.03 & \\
\hline
\end{tabular}

Table B.8: Final bulk density values for the Caliper Method for Rock Type 4: Various Carbonates

\begin{tabular}{|c|c|c|c|}
\hline Sample ID & Volume $\left(\mathrm{cm}^{\wedge} 3\right)$ & Weight $(\mathrm{g})$ & Density $\left(\mathrm{g} / \mathrm{cm}^{\wedge} 3\right)$ \\
\hline $4-1-1$ & 178.24 & 456.25 & 2.56 \\
\hline $4-1-2$ & 179.75 & 491.50 & 2.73 \\
\hline $4-1-3$ & 239.87 & 646.69 & 2.70 \\
\hline $4-1-4$ & 288.96 & 794.62 & 2.75 \\
\hline
\end{tabular}




\begin{tabular}{|c|c|c|c|}
\hline Sample ID & Volume $\left(\mathrm{cm}^{\wedge} 3\right)$ & Weight $(\mathrm{g})$ & Density $\left(\mathrm{g} / \mathrm{cm}^{\wedge} 3\right)$ \\
\hline $4-1-5$ & 171.39 & 468.99 & 2.74 \\
\hline $4-2-1$ & 167.98 & 448.03 & 2.67 \\
\hline $4-2-2$ & 177.40 & 470.53 & 2.65 \\
\hline $4-2-3$ & 182.32 & 478.23 & 2.62 \\
\hline $4-3-1$ & 71.03 & 196.08 & 2.76 \\
\hline $4-3-2$ & 134.69 & 361.56 & 2.68 \\
\hline $4-3-3$ & 124.72 & 331.71 & 2.66 \\
\hline $4-4-1$ & 129.52 & 343.58 & 2.65 \\
\hline $4-4-2$ & 157.33 & 412.18 & 2.62 \\
\hline $4-4-3$ & 143.87 & 381.02 & 2.65 \\
\hline $4-5-1$ & 224.53 & 593.92 & 2.65 \\
\hline
\end{tabular}

Table B.9: Dimension determination for the Caliper Method for Rock Type 5: Water Cooled Slag

\begin{tabular}{|c|c|c|c|c|c|c|}
\hline $\begin{array}{c}\text { Sample } \\
\text { ID }\end{array}$ & $\begin{array}{c}\text { Diameter } \\
(\mathrm{mm})\end{array}$ & $\begin{array}{c}\text { Diameter } \\
(\mathrm{cm})\end{array}$ & $\begin{array}{c}\text { Average } \\
\text { Diameter } \\
(\mathrm{cm})\end{array}$ & $\begin{array}{c}\text { Length } \\
(\mathrm{mm})\end{array}$ & $\begin{array}{c}\text { Length } \\
(\mathrm{cm})\end{array}$ & $\begin{array}{c}\text { Average } \\
\text { Length }(\mathrm{cm})\end{array}$ \\
\hline \multirow{4}{*}{$5-1-1$} & 47.44 & 4.74 & \multirow{4}{*}{4.75} & 103.88 & 10.39 & \multirow{4}{*}{10.37} \\
\hline & 47.48 & 4.75 & & 103.57 & 10.36 & \\
\hline & 47.45 & 4.75 & & 103.79 & 10.38 & \\
\hline & 47.47 & 4.75 & & 103.37 & 10.34 & \\
\hline \multirow{4}{*}{$5-1-2$} & 47.43 & 4.74 & \multirow{4}{*}{4.75} & 96.47 & 9.65 & \multirow{4}{*}{9.64} \\
\hline & 47.64 & 4.76 & & 96.45 & 9.65 & \\
\hline & 47.40 & 4.74 & & 96.67 & 9.67 & \\
\hline & 47.36 & 4.74 & & 96.12 & 9.61 & \\
\hline \multirow{4}{*}{$5-1-3$} & 47.65 & 4.77 & \multirow{4}{*}{4.75} & 106.99 & 10.70 & \multirow{4}{*}{10.72} \\
\hline & 47.66 & 4.77 & & 107.35 & 10.74 & \\
\hline & 47.47 & 4.75 & & 107.73 & 10.77 & \\
\hline & 47.38 & 4.74 & & 106.87 & 10.69 & \\
\hline \multirow{4}{*}{$5-1-4$} & 47.59 & 4.76 & \multirow{4}{*}{4.75} & 104.89 & 10.49 & \multirow{4}{*}{10.47} \\
\hline & 47.43 & 4.74 & & 104.55 & 10.46 & \\
\hline & 47.40 & 4.74 & & 104.55 & 10.46 & \\
\hline & 47.45 & 4.75 & & 104.66 & 10.47 & \\
\hline \multirow{4}{*}{$5-1-5$} & 47.43 & 4.74 & \multirow{4}{*}{4.75} & 97.54 & 9.75 & \multirow{4}{*}{9.78} \\
\hline & 47.50 & 4.75 & & 97.59 & 9.76 & \\
\hline & 47.41 & 4.74 & & 97.58 & 9.76 & \\
\hline & 47.49 & 4.75 & & 98.32 & 9.83 & \\
\hline
\end{tabular}




\begin{tabular}{|c|c|c|c|c|c|c|}
\hline $\begin{array}{c}\text { Sample } \\
\text { ID }\end{array}$ & $\begin{array}{l}\text { Diameter } \\
(\mathrm{mm})\end{array}$ & $\begin{array}{l}\text { Diameter } \\
(\mathrm{cm})\end{array}$ & $\begin{array}{c}\text { Average } \\
\text { Diameter } \\
(\mathrm{cm})\end{array}$ & $\begin{array}{c}\text { Length } \\
(\mathrm{mm})\end{array}$ & $\begin{array}{c}\text { Length } \\
(\mathrm{cm})\end{array}$ & $\begin{array}{c}\text { Average } \\
\text { Length }(\mathrm{cm})\end{array}$ \\
\hline \multirow{4}{*}{$5-2-1$} & 47.35 & 4.74 & \multirow{4}{*}{4.74} & 103.54 & 10.35 & \multirow{4}{*}{10.38} \\
\hline & 47.50 & 4.75 & & 103.79 & 10.38 & \\
\hline & 47.54 & 4.75 & & 103.91 & 10.39 & \\
\hline & 47.37 & 4.74 & & 104.14 & 10.41 & \\
\hline \multirow{4}{*}{$5-2-2$} & 47.46 & 4.75 & \multirow{4}{*}{4.74} & 104.19 & 10.42 & \multirow{4}{*}{10.42} \\
\hline & 47.41 & 4.74 & & 104.29 & 10.43 & \\
\hline & 47.42 & 4.74 & & 104.18 & 10.42 & \\
\hline & 47.42 & 4.74 & & 104.02 & 10.40 & \\
\hline \multirow{4}{*}{$5-2-3$} & 47.47 & 4.75 & \multirow{4}{*}{4.74} & 131.94 & 13.19 & \multirow{4}{*}{13.24} \\
\hline & 47.47 & 4.75 & & 132.41 & 13.24 & \\
\hline & 47.41 & 4.74 & & 133.00 & 13.30 & \\
\hline & 47.41 & 4.74 & & 132.23 & 13.22 & \\
\hline \multirow{4}{*}{$5-2-5$} & 47.37 & 4.74 & \multirow{4}{*}{4.74} & 93.32 & 9.33 & \multirow{4}{*}{9.34} \\
\hline & 47.38 & 4.74 & & 93.60 & 9.36 & \\
\hline & 47.38 & 4.74 & & 93.55 & 9.36 & \\
\hline & 47.36 & 4.74 & & 93.32 & 9.33 & \\
\hline \multirow{4}{*}{$5-3-1$} & 47.21 & 4.72 & \multirow{4}{*}{4.72} & 104.68 & 10.47 & \multirow{4}{*}{10.48} \\
\hline & 47.21 & 4.72 & & 104.79 & 10.48 & \\
\hline & 47.08 & 4.71 & & 104.74 & 10.47 & \\
\hline & 47.22 & 4.72 & & 105.10 & 10.51 & \\
\hline \multirow{4}{*}{$5-3-2$} & 47.16 & 4.72 & \multirow{4}{*}{4.72} & 103.7 & 10.37 & \multirow{4}{*}{10.37} \\
\hline & 47.14 & 4.71 & & 103.55 & 10.36 & \\
\hline & 47.2 & 4.72 & & 103.63 & 10.36 & \\
\hline & 47.13 & 4.71 & & 103.98 & 10.40 & \\
\hline \multirow{4}{*}{$5-3-3$} & 47.03 & 4.70 & \multirow{4}{*}{4.72} & 103.57 & 10.36 & \multirow{4}{*}{10.33} \\
\hline & 47.29 & 4.73 & & 103.13 & 10.31 & \\
\hline & 47.12 & 4.71 & & 103.17 & 10.32 & \\
\hline & 47.19 & 4.72 & & 103.23 & 10.32 & \\
\hline
\end{tabular}

Table B.10: Final bulk density values for the Caliper Method for Rock Type 5: Water Cooled Slag

\begin{tabular}{|c|c|c|c|}
\hline Sample ID & Volume $\left(\mathrm{cm}^{\wedge} 3\right)$ & Weight $(\mathrm{g})$ & Density $\left(\mathrm{g} / \mathrm{cm}^{\wedge} 3\right)$ \\
\hline $5-1-1$ & 183.37 & 419.26 & 2.29 \\
\hline $5-1-2$ & 170.57 & 395.32 & 2.32 \\
\hline $5-1-3$ & 190.35 & 433.40 & 2.28 \\
\hline
\end{tabular}




\begin{tabular}{|c|c|c|c|}
\hline Sample ID & Volume $\left(\mathrm{cm}^{\wedge} 3\right)$ & Weight $(\mathrm{g})$ & Density $\left(\mathrm{g} / \mathrm{cm}^{\wedge} 3\right)$ \\
\hline $5-1-4$ & 185.21 & 425.68 & 2.30 \\
\hline $5-1-5$ & 172.92 & 341.76 & 1.98 \\
\hline $5-2-1$ & 183.55 & 366.51 & 2.00 \\
\hline $5-2-2$ & 184.03 & 451.20 & 2.45 \\
\hline $5-2-3$ & 234.02 & 507.82 & 2.17 \\
\hline $5-2-5$ & 164.71 & 320.62 & 1.95 \\
\hline $5-3-1$ & 183.27 & 390.37 & 2.13 \\
\hline $5-3-2$ & 181.15 & 366.57 & 2.02 \\
\hline $5-3-3$ & 180.38 & 350.12 & 1.94 \\
\hline
\end{tabular}

Table B-11: Dimension determination for the Caliper Method for Rock Type 6: Jacobsville Sandstone

\begin{tabular}{|c|c|c|c|c|c|c|}
\hline $\begin{array}{l}\text { Sample } \\
\text { ID }\end{array}$ & $\begin{array}{l}\text { Diameter } \\
(\mathrm{mm})\end{array}$ & $\begin{array}{l}\text { Diameter } \\
(\mathrm{cm})\end{array}$ & $\begin{array}{c}\text { Average } \\
\text { Diameter } \\
(\mathrm{cm})\end{array}$ & $\begin{array}{c}\text { Length } \\
(\mathrm{mm})\end{array}$ & $\begin{array}{l}\text { Length } \\
(\mathrm{cm})\end{array}$ & $\begin{array}{c}\text { Average } \\
\text { Length } \\
\text { (cm) }\end{array}$ \\
\hline \multirow{4}{*}{$6-1-1$} & 47.13 & 4.71 & \multirow{4}{*}{4.72} & 102.50 & 10.25 & \multirow{4}{*}{10.26} \\
\hline & 47.22 & 4.72 & & 102.75 & 10.28 & \\
\hline & 47.22 & 4.72 & & 102.74 & 10.27 & \\
\hline & 47.18 & 4.72 & & 102.49 & 10.25 & \\
\hline \multirow{4}{*}{$6-1-2$} & 47.31 & 4.73 & \multirow{4}{*}{4.72} & 101.32 & 10.13 & \multirow{4}{*}{10.15} \\
\hline & 47.22 & 4.72 & & 101.49 & 10.15 & \\
\hline & 47.13 & 4.71 & & 101.58 & 10.16 & \\
\hline & 47.20 & 4.72 & & 101.80 & 10.18 & \\
\hline \multirow{4}{*}{$6-1-3$} & 47.21 & 4.72 & \multirow{4}{*}{4.71} & 101.23 & 10.12 & \multirow{4}{*}{10.14} \\
\hline & 47.13 & 4.71 & & 101.47 & 10.15 & \\
\hline & 47.11 & 4.71 & & 101.32 & 10.13 & \\
\hline & 47.14 & 4.71 & & 101.67 & 10.17 & \\
\hline \multirow{4}{*}{$6-1-4$} & 47.11 & 4.71 & \multirow{4}{*}{4.71} & 102.71 & 10.27 & \multirow{4}{*}{10.28} \\
\hline & 47.13 & 4.71 & & 102.70 & 10.27 & \\
\hline & 47.08 & 4.71 & & 103.00 & 10.30 & \\
\hline & 47.07 & 4.71 & & 102.87 & 10.29 & \\
\hline \multirow{4}{*}{$6-1-5$} & 47.14 & 4.71 & \multirow{4}{*}{4.72} & 104.39 & 10.44 & \multirow{4}{*}{10.43} \\
\hline & 47.28 & 4.73 & & 104.37 & 10.44 & \\
\hline & 47.22 & 4.72 & & 104.20 & 10.42 & \\
\hline & 47.08 & 4.71 & & 104.28 & 10.43 & \\
\hline \multirow{4}{*}{$6-1-6$} & 47.06 & 4.71 & \multirow{4}{*}{4.70} & 101.66 & 10.17 & \multirow{4}{*}{10.16} \\
\hline & 46.96 & 4.70 & & 101.71 & 10.17 & \\
\hline & 46.89 & 4.69 & & 101.65 & 10.17 & \\
\hline & 47.00 & 4.70 & & 101.48 & 10.15 & \\
\hline
\end{tabular}




\begin{tabular}{|c|c|c|c|c|c|c|}
\hline $\begin{array}{c}\text { Sample } \\
\text { ID }\end{array}$ & $\begin{array}{c}\text { Diameter } \\
(\mathrm{mm})\end{array}$ & $\begin{array}{c}\text { Diameter } \\
(\mathrm{cm})\end{array}$ & $\begin{array}{c}\text { Average } \\
\text { Diameter } \\
(\mathrm{cm})\end{array}$ & $\begin{array}{c}\text { Length } \\
(\mathrm{mm})\end{array}$ & $\begin{array}{c}\text { Length } \\
(\mathrm{cm})\end{array}$ & $\begin{array}{c}\text { Average } \\
\text { Length }(\mathrm{cm})\end{array}$ \\
\hline \multirow{4}{*}{$6-1-7$} & 47.15 & 4.72 & \multirow{4}{*}{4.71} & 105.21 & 10.52 & \multirow{4}{*}{10.52} \\
\hline & 47.23 & 4.72 & & 105.16 & 10.52 & \\
\hline & 47.08 & 4.71 & & 105.22 & 10.52 & \\
\hline & 47.11 & 4.71 & & 105.24 & 10.52 & \\
\hline \multirow{4}{*}{$6-1-8$} & 47.34 & 4.73 & \multirow{4}{*}{4.73} & 103.13 & 10.31 & \multirow{4}{*}{10.31} \\
\hline & 47.20 & 4.72 & & 103.22 & 10.32 & \\
\hline & 47.27 & 4.73 & & 102.95 & 10.30 & \\
\hline & 47.24 & 4.72 & & 102.95 & 10.30 & \\
\hline \multirow{4}{*}{$6-1-9$} & 47.13 & 4.71 & \multirow{4}{*}{4.72} & 103.60 & 10.36 & \multirow{4}{*}{10.34} \\
\hline & 47.39 & 4.74 & & 103.30 & 10.33 & \\
\hline & 47.22 & 4.72 & & 103.46 & 10.35 & \\
\hline & 47.18 & 4.72 & & 103.15 & 10.32 & \\
\hline \multirow{4}{*}{$6-1-10$} & 47.11 & 4.71 & \multirow{4}{*}{4.72} & 103.85 & 10.39 & \multirow{4}{*}{10.35} \\
\hline & 47.10 & 4.71 & & 103.34 & 10.33 & \\
\hline & 47.18 & 4.72 & & 103.35 & 10.34 & \\
\hline & 47.28 & 4.73 & & 103.39 & 10.34 & \\
\hline \multirow{4}{*}{$6-1-11$} & 47.11 & 4.71 & \multirow{4}{*}{4.72} & 104.60 & 10.46 & \multirow{4}{*}{10.49} \\
\hline & 47.10 & 4.71 & & 105.95 & 10.60 & \\
\hline & 47.22 & 4.72 & & 104.39 & 10.44 & \\
\hline & 47.32 & 4.73 & & 104.66 & 10.47 & \\
\hline \multirow{4}{*}{$6-1-12$} & 47.12 & 4.71 & \multirow{4}{*}{4.72} & 102.11 & 10.21 & \multirow{4}{*}{10.21} \\
\hline & 47.20 & 4.72 & & 102.05 & 10.21 & \\
\hline & 47.15 & 4.72 & & 102.15 & 10.22 & \\
\hline & 47.39 & 4.74 & & 102.06 & 10.21 & \\
\hline
\end{tabular}

Table B-12: Final bulk density values for the Caliper Method for Rock Type 6: Jacobsville Sandstone

\begin{tabular}{|c|c|c|c|}
\hline Sample ID & Volume $\left(\mathrm{cm}^{\wedge} 3\right)$ & Weight $(\mathrm{g})$ & Density $\left(\mathrm{g} / \mathrm{cm}^{\wedge} 3\right)$ \\
\hline $6-1-1$ & 179.46 & 378.77 & 2.11 \\
\hline $6-1-2$ & 177.79 & 374.95 & 2.11 \\
\hline $6-1-3$ & 177.07 & 372.38 & 2.10 \\
\hline $6-1-4$ & 179.13 & 376.76 & 2.10 \\
\hline $6-1-5$ & 182.36 & 382.69 & 2.10 \\
\hline $6-1-6$ & 176.14 & 371.64 & 2.11 \\
\hline $6-1-7$ & 183.64 & 387.53 & 2.11 \\
\hline $6-1-8$ & 180.81 & 379.25 & 2.10 \\
\hline $6-1-9$ & 181.11 & 380.41 & 2.10 \\
\hline
\end{tabular}




\begin{tabular}{|c|c|c|c|}
\hline Sample ID & Volume $\left(\mathrm{cm}^{\wedge} 3\right)$ & Weight $(\mathrm{g})$ & Density $\left(\mathrm{g} / \mathrm{cm}^{\wedge} 3\right)$ \\
\hline $6-1-10$ & 180.82 & 377.22 & 2.09 \\
\hline $6-1-11$ & 183.45 & 382.87 & 2.09 \\
\hline $6-1-12$ & 178.75 & 377.40 & 2.11 \\
\hline
\end{tabular}

Table B-13: Dimension determination for the Caliper Method for Rock Type 7: Air Cooled Slag

\begin{tabular}{|c|c|c|c|c|c|c|}
\hline $\begin{array}{c}\text { Sample } \\
\text { ID }\end{array}$ & $\begin{array}{c}\text { Diameter } \\
(\mathrm{mm})\end{array}$ & $\begin{array}{c}\text { Diameter } \\
(\mathrm{cm})\end{array}$ & $\begin{array}{c}\text { Average } \\
\text { Diameter } \\
(\mathrm{cm})\end{array}$ & $\begin{array}{c}\text { Length } \\
(\mathrm{mm})\end{array}$ & $\begin{array}{l}\text { Length } \\
(\mathrm{cm})\end{array}$ & $\begin{array}{c}\text { Average } \\
\text { Length } \\
\text { (cm) }\end{array}$ \\
\hline \multirow{4}{*}{$7-1$} & 50.92 & 5.09 & \multirow{4}{*}{5.10} & 89.17 & 8.92 & \multirow{4}{*}{8.93} \\
\hline & 51.25 & 5.13 & & 89.25 & 8.93 & \\
\hline & 50.86 & 5.09 & & 89.67 & 8.97 & \\
\hline & 51.00 & 5.10 & & 89.05 & 8.91 & \\
\hline \multirow{4}{*}{$7-2$} & 50.95 & 5.10 & \multirow{4}{*}{5.10} & 79.41 & 7.94 & \multirow{4}{*}{7.93} \\
\hline & 50.99 & 5.10 & & 79.32 & 7.93 & \\
\hline & 50.92 & 5.09 & & 79.48 & 7.95 & \\
\hline & 51.02 & 5.10 & & 79.11 & 7.91 & \\
\hline \multirow{4}{*}{$7-3$} & 51.04 & 5.10 & \multirow{4}{*}{5.11} & 81.23 & 8.12 & \multirow{4}{*}{8.12} \\
\hline & 50.98 & 5.10 & & 81.38 & 8.14 & \\
\hline & 51.15 & 5.12 & & 81.21 & 8.12 & \\
\hline & 51.18 & 5.12 & & 80.97 & 8.10 & \\
\hline \multirow{4}{*}{$7-4$} & 50.91 & 5.09 & \multirow{4}{*}{5.09} & 88.72 & 8.87 & \multirow{4}{*}{8.86} \\
\hline & 50.93 & 5.09 & & 89.02 & 8.90 & \\
\hline & 50.99 & 5.10 & & 88.22 & 8.82 & \\
\hline & 50.85 & 5.09 & & 88.42 & 8.84 & \\
\hline \multirow{4}{*}{$7-5$} & 50.97 & 5.10 & \multirow{4}{*}{5.10} & 86.05 & 8.61 & \multirow{4}{*}{8.60} \\
\hline & 50.92 & 5.09 & & 85.95 & 8.60 & \\
\hline & 51.10 & 5.11 & & 85.98 & 8.60 & \\
\hline & 50.97 & 5.10 & & 85.94 & 8.59 & \\
\hline \multirow{4}{*}{$7-6$} & 50.95 & 5.10 & \multirow{4}{*}{5.10} & 88.29 & 8.83 & \multirow{4}{*}{8.82} \\
\hline & 51.06 & 5.11 & & 88.31 & 8.83 & \\
\hline & 50.99 & 5.10 & & 88.26 & 8.83 & \\
\hline & 50.93 & 5.09 & & 88.11 & 8.81 & \\
\hline \multirow{4}{*}{$7-7$} & 50.96 & 5.10 & \multirow{4}{*}{5.09} & 118.49 & 11.85 & \multirow{4}{*}{11.85} \\
\hline & 50.96 & 5.10 & & 118.32 & 11.83 & \\
\hline & 50.71 & 5.07 & & 118.49 & 11.85 & \\
\hline & 50.96 & 5.10 & & 118.68 & 11.87 & \\
\hline \multirow{4}{*}{$7-8$} & 51.00 & 5.10 & \multirow{4}{*}{5.10} & 96.21 & 9.62 & \multirow{4}{*}{9.64} \\
\hline & 50.99 & 5.10 & & 95.89 & 9.59 & \\
\hline & 51.02 & 5.10 & & 96.76 & 9.68 & \\
\hline & 51.07 & 5.11 & & 96.70 & 9.67 & \\
\hline
\end{tabular}


Table B-14: Final bulk density values for the Caliper Method for Rock Type 7: Air Cooled Slag

\begin{tabular}{|l|r|r|r|}
\hline Sample ID & Volume $\left(\mathrm{cm}^{\wedge} 3\right)$ & Weight $(\mathrm{g})$ & \multicolumn{1}{c|}{ Density $\left(\mathrm{g} / \mathrm{cm}^{\wedge} 3\right)$} \\
\hline $7-1$ & 182.45 & 384.13 & 2.11 \\
\hline $7-2$ & 161.87 & 349.15 & 2.16 \\
\hline $7-3$ & 166.44 & 344.60 & 2.07 \\
\hline $7-4$ & 180.42 & 320.59 & 1.78 \\
\hline $7-5$ & 175.57 & 384.48 & 2.19 \\
\hline $7-6$ & 180.14 & 380.55 & 2.11 \\
\hline $7-7$ & 241.09 & 480.14 & 1.99 \\
\hline $7-8$ & 197.05 & 354.09 & 1.80 \\
\hline
\end{tabular}

Table B-15: Dimension determination for $25 \%$ of the samples for quality control.

\begin{tabular}{|c|c|c|c|c|c|c|}
\hline $\begin{array}{l}\text { Sample } \\
\text { ID }\end{array}$ & $\begin{array}{l}\text { Diameter } \\
(\mathrm{mm})\end{array}$ & $\begin{array}{l}\text { Diameter } \\
(\mathrm{cm})\end{array}$ & $\begin{array}{c}\text { Average } \\
\text { Diameter } \\
(\mathrm{cm})\end{array}$ & $\begin{array}{c}\text { Length } \\
(\mathrm{mm})\end{array}$ & $\begin{array}{l}\text { Length } \\
(\mathrm{cm})\end{array}$ & $\begin{array}{c}\text { Average } \\
\text { Length }(\mathrm{cm})\end{array}$ \\
\hline \multirow{4}{*}{$1-1-2$} & 47.70 & 4.77 & \multirow{4}{*}{4.75} & 100.36 & 10.04 & \multirow{4}{*}{10.07} \\
\hline & 47.43 & 4.74 & & 100.63 & 10.06 & \\
\hline & 47.39 & 4.74 & & 100.72 & 10.07 & \\
\hline & 47.50 & 4.75 & & 101.03 & 10.10 & \\
\hline \multirow{4}{*}{$1-1-4$} & 47.42 & 4.74 & \multirow{4}{*}{4.76} & 95.73 & 9.57 & \multirow{4}{*}{9.56} \\
\hline & 47.76 & 4.78 & & 95.60 & 9.56 & \\
\hline & 47.57 & 4.76 & & 95.67 & 9.57 & \\
\hline & 47.62 & 4.76 & & 95.57 & 9.56 & \\
\hline \multirow{4}{*}{$2-1-3$} & 47.25 & 4.73 & \multirow{4}{*}{4.73} & 106.58 & 10.66 & \multirow{4}{*}{10.67} \\
\hline & 47.33 & 4.73 & & 106.56 & 10.66 & \\
\hline & 47.44 & 4.74 & & 106.75 & 10.68 & \\
\hline & 47.25 & 4.73 & & 106.77 & 10.68 & \\
\hline \multirow{4}{*}{$2-2-3$} & 47.44 & 4.74 & \multirow{4}{*}{4.75} & 106.19 & 10.62 & \multirow{4}{*}{10.60} \\
\hline & 47.48 & 4.75 & & 105.88 & 10.59 & \\
\hline & 47.55 & 4.76 & & 106.07 & 10.61 & \\
\hline & 47.56 & 4.76 & & 106.05 & 10.61 & \\
\hline \multirow{4}{*}{$3-3-1$} & 47.24 & 4.72 & \multirow{4}{*}{4.71} & 71.69 & 7.17 & \multirow{4}{*}{7.18} \\
\hline & 47.14 & 4.71 & & 71.94 & 7.19 & \\
\hline & 47.08 & 4.71 & & 71.85 & 7.19 & \\
\hline & 47.12 & 4.71 & & 71.87 & 7.19 & \\
\hline
\end{tabular}




\begin{tabular}{|c|c|c|c|c|c|c|}
\hline $\begin{array}{l}\text { Sample } \\
\text { ID }\end{array}$ & $\begin{array}{l}\text { Diameter } \\
(\mathrm{mm})\end{array}$ & $\begin{array}{c}\text { Diameter } \\
(\mathrm{cm})\end{array}$ & $\begin{array}{c}\text { Average } \\
\text { Diameter } \\
(\mathrm{cm})\end{array}$ & $\begin{array}{c}\text { Length } \\
(\mathrm{mm})\end{array}$ & $\begin{array}{l}\text { Length } \\
(\mathrm{cm})\end{array}$ & $\begin{array}{c}\text { Average } \\
\text { Length }(\mathrm{cm})\end{array}$ \\
\hline \multirow{4}{*}{$4-1-2$} & 47.10 & 4.71 & \multirow{4}{*}{4.71} & 102.53 & 10.25 & \multirow{4}{*}{10.26} \\
\hline & 47.09 & 4.71 & & 102.57 & 10.26 & \\
\hline & 47.11 & 4.71 & & 102.61 & 10.26 & \\
\hline & 47.12 & 4.71 & & 102.49 & 10.25 & \\
\hline \multirow{4}{*}{$4-2-3$} & 46.81 & 4.68 & \multirow{4}{*}{4.69} & 105.80 & 10.58 & \multirow{4}{*}{10.54} \\
\hline & 46.84 & 4.68 & & 105.15 & 10.52 & \\
\hline & 46.87 & 4.69 & & 105.22 & 10.52 & \\
\hline & 46.98 & 4.70 & & 105.38 & 10.54 & \\
\hline \multirow{4}{*}{$4-3-2$} & 47.06 & 4.71 & \multirow{4}{*}{4.71} & 77.17 & 7.72 & \multirow{4}{*}{7.72} \\
\hline & 47.04 & 4.70 & & 77.58 & 7.76 & \\
\hline & 47.03 & 4.70 & & 77.11 & 7.71 & \\
\hline & 47.07 & 4.71 & & 77.07 & 7.71 & \\
\hline \multirow{4}{*}{$4-4-2$} & 47.44 & 4.74 & \multirow{4}{*}{4.74} & 89.17 & 8.92 & \multirow{4}{*}{8.92} \\
\hline & 47.49 & 4.75 & & 89.26 & 8.93 & \\
\hline & 47.39 & 4.74 & & 89.13 & 8.91 & \\
\hline & 47.40 & 4.74 & & 89.20 & 8.92 & \\
\hline \multirow{4}{*}{$4-5-1$} & 46.81 & 4.68 & \multirow{4}{*}{4.68} & 129.98 & 13.00 & \multirow{4}{*}{13.01} \\
\hline & 46.75 & 4.68 & & 130.14 & 13.01 & \\
\hline & 46.98 & 4.70 & & 130.19 & 13.02 & \\
\hline & 46.84 & 4.68 & & 129.91 & 12.99 & \\
\hline \multirow{4}{*}{$5-1-1$} & 47.46 & 4.75 & \multirow{4}{*}{4.75} & 103.91 & 10.39 & \multirow{4}{*}{10.38} \\
\hline & 47.53 & 4.75 & & 103.51 & 10.35 & \\
\hline & 47.41 & 4.74 & & 103.99 & 10.40 & \\
\hline & 47.43 & 4.74 & & 103.81 & 10.38 & \\
\hline \multirow{4}{*}{$5-1-5$} & 47.44 & 4.74 & \multirow{4}{*}{4.75} & 83.78 & 8.38 & \multirow{4}{*}{8.39} \\
\hline & 47.68 & 4.77 & & 84.04 & 8.40 & \\
\hline & 47.42 & 4.74 & & 83.86 & 8.39 & \\
\hline & 47.59 & 4.76 & & 83.78 & 8.38 & \\
\hline \multirow{4}{*}{$5-2-3$} & 47.47 & 4.75 & \multirow{4}{*}{4.74} & 120.79 & 12.08 & \multirow{4}{*}{12.06} \\
\hline & 47.43 & 4.74 & & 120.41 & 12.04 & \\
\hline & 47.41 & 4.74 & & 120.53 & 12.05 & \\
\hline & 47.44 & 4.74 & & 120.62 & 12.06 & \\
\hline \multirow{4}{*}{$6-1-12$} & 47.23 & 4.72 & \multirow{4}{*}{4.73} & 102.02 & 10.20 & \multirow{4}{*}{10.21} \\
\hline & 47.13 & 4.71 & & 102.10 & 10.21 & \\
\hline & 47.25 & 4.73 & & 102.04 & 10.20 & \\
\hline & 47.55 & 4.76 & & 102.08 & 10.21 & \\
\hline
\end{tabular}




\begin{tabular}{|c|c|c|c|c|c|c|}
\hline $\begin{array}{l}\text { Sample } \\
\text { ID }\end{array}$ & $\begin{array}{l}\text { Diameter } \\
(\mathrm{mm})\end{array}$ & $\begin{array}{l}\text { Diameter } \\
(\mathrm{cm})\end{array}$ & $\begin{array}{c}\text { Average } \\
\text { Diameter } \\
(\mathrm{cm})\end{array}$ & $\begin{array}{c}\text { Length } \\
(\mathrm{mm})\end{array}$ & $\begin{array}{c}\text { Length } \\
(\mathrm{cm})\end{array}$ & $\begin{array}{c}\text { Average } \\
\text { Length }(\mathrm{cm})\end{array}$ \\
\hline \multirow{4}{*}{$6-1-5$} & 47.12 & 4.71 & \multirow{4}{*}{4.72} & 104.40 & 10.44 & \multirow{4}{*}{10.44} \\
\hline & 47.18 & 4.72 & & 104.45 & 10.45 & \\
\hline & 47.20 & 4.72 & & 104.30 & 10.43 & \\
\hline & 47.10 & 4.71 & & 104.31 & 10.43 & \\
\hline \multirow{4}{*}{$7-3$} & 50.90 & 5.09 & \multirow{4}{*}{5.09} & 98.37 & 9.84 & \multirow{4}{*}{9.84} \\
\hline & 50.95 & 5.10 & & 98.29 & 9.83 & \\
\hline & 50.96 & 5.10 & & 98.41 & 9.84 & \\
\hline & 50.94 & 5.09 & & 98.56 & 9.86 & \\
\hline \multirow{4}{*}{$7-5$} & 51.02 & 5.10 & \multirow{4}{*}{5.10} & 101.32 & 10.13 & \multirow{4}{*}{10.14} \\
\hline & 50.94 & 5.09 & & 101.54 & 10.15 & \\
\hline & 50.86 & 5.09 & & 101.36 & 10.14 & \\
\hline & 51.02 & 5.10 & & 101.42 & 10.14 & \\
\hline
\end{tabular}

Table B-16: Final Bulk Density values for the selected QA/QC samples

\begin{tabular}{|c|c|c|c|}
\hline Sample ID & Volume $\left(\mathrm{cm}^{\wedge} 3\right)$ & Weight $(\mathrm{g})$ & Density $\left(\mathrm{g} / \mathrm{cm}^{\wedge} 3\right)$ \\
\hline $1-1-2$ & 178.46 & 466.37 & 2.61 \\
\hline $1-1-4$ & 170.14 & 444.14 & 2.61 \\
\hline $2-1-3$ & 187.57 & 510.82 & 2.72 \\
\hline $2-2-3$ & 187.98 & 532.25 & 2.83 \\
\hline $3-3-1$ & 125.40 & 338.80 & 2.70 \\
\hline $4-1-2$ & 178.71 & 491.51 & 2.75 \\
\hline $4-2-3$ & 181.87 & 478.23 & 2.63 \\
\hline $4-3-2$ & 134.28 & 361.73 & 2.69 \\
\hline $4-4-2$ & 157.58 & 412.18 & 2.62 \\
\hline $4-5-1$ & 224.15 & 594.42 & 2.65 \\
\hline $5-1-1$ & 183.62 & 419.26 & 2.28 \\
\hline $5-1-5$ & 148.82 & 341.76 & 2.30 \\
\hline $5-2-3$ & 213.13 & 507.83 & 2.38 \\
\hline $6-1-12$ & 179.26 & 377.87 & 2.11 \\
\hline $6-1-5$ & 182.23 & 383.26 & 2.10 \\
\hline $7-3$ & 165.95 & 344.60 & 2.08 \\
\hline $7-5$ & 174.76 & 384.48 & 2.20 \\
\hline
\end{tabular}


Table B-17: Percent difference between the QA/QC sample and the original calculated bulk density

\begin{tabular}{|c|c|c|c|}
\hline $\begin{array}{c}\text { Sample } \\
\text { ID }\end{array}$ & $\begin{array}{c}\text { Original Caliper Density } \\
\left(\mathrm{g} / \mathrm{cm}^{\wedge} 3\right)\end{array}$ & $\begin{array}{c}\text { QA/QC Density } \\
\left(\mathrm{g} / \mathrm{cm}^{\wedge} 3\right)\end{array}$ & $\begin{array}{c}\text { Percent Difference } \\
(\%)\end{array}$ \\
\hline $1-1-2$ & 2.61 & 2.61 & -0.13 \\
\hline $1-1-4$ & 2.61 & 2.61 & -0.01 \\
\hline $2-1-3$ & 2.73 & 2.72 & 0.24 \\
\hline $2-2-3$ & 2.83 & 2.83 & -0.05 \\
\hline $3-3-1$ & 2.71 & 2.70 & 0.31 \\
\hline $4-1-2$ & 2.73 & 2.75 & -0.74 \\
\hline $4-2-3$ & 2.62 & 2.63 & -0.36 \\
\hline $4-3-2$ & 2.68 & 2.69 & -0.52 \\
\hline $4-4-2$ & 2.62 & 2.62 & 0.17 \\
\hline $4-5-1$ & 2.65 & 2.65 & -0.07 \\
\hline $5-1-1$ & 2.29 & 2.28 & 0.29 \\
\hline $5-1-5$ & 2.29 & 2.30 & -0.28 \\
\hline $5-2-3$ & 2.38 & 2.38 & -0.12 \\
\hline $6-1-5$ & 2.1 & 2.10 & -0.15 \\
\hline $6-1-12$ & 2.11 & 2.11 & 0.10 \\
\hline $7-3$ & 2.07 & 2.08 & -0.48 \\
\hline $7-5$ & 2.19 & 2.20 & -0.46 \\
\hline
\end{tabular}




\section{Appendix C: Instantaneous Water Immersion Results and Procedures}

The second method evaluated for bulk density determination, is the Instantaneous Water Immersion Method. The term, "instantaneous" is key, due to the requirement to measure the suspended weight of the sample quickly, prior to fluid beginning to enter the internal pore space of the sample.

The Instantaneous Water Immersion method, results in a bulk density measurement. The volume of the sample is calculated by comparing the difference between the submerged weight of the sample and the dry weight of the sample. The most common fluid to suspend the sample in is water; however, any incompressible fluid with a known density can be used. Water is by far the simplest fluid to use, since at room temperature, the specific gravity of water is one. If any other fluid is used in further testing, all data will need to be adjusted in order to factor in a different specific gravity.

Another advantage of utilizing this method is that all equipment needed is relatively easy to acquire and use. By far, the only potentially expensive piece of equipment required is a balance.

Additionally, there is no lasting harm done to the core as the sample can easily be dried after testing is completed. If water is used to suspend the sample no lasting contamination of the core will be done as well. This allows all testing to be reproduced at a future point if needed.

Since there is no requirement for a perfect geometric shape using this method, core samples that are highly fractured or in several pieces are still able to be tested with minimal additional issues.

This method still has several issues that may result in an inaccurate volume being calculated. It can, in several situations, be highly difficult to collect an accurate submerged weight on a sample. As a sample is placed in a basket suspended in water, the measurement will be inaccurate until the sample comes to rest. This can take several seconds depending on other outside factors. During this time, water can continue to permeate the sample. While the rate of water variation will vary, depending on the permeability of the sample, for materials with high permeability this can be a serious cause for concern.

There are several ways to minimize the impact of the water entering the pores. One method is to use a larger sample, as the increase in weight will be offset by a larger volume. 
Another way is to coat the sample in wax, or a combination of wax and saran wrap to prevent water moving into the pores. These methods, Wax Immersion and Wax-Saran Wrap Immersion are discussed later in Appendix D and Appendix E respectively.

The necessary equipment for this method is very basic. A scale needs to be selected that is capable of measuring out to 0.01 grams and being loaded from the bottom, in order to obtain the suspended weight of the sample. A table or bench is needed as well, in order to suspend the scale over a plastic tub. The tub needs to be deep enough to allow for the samples to be completely covered with water, and large enough in surface area that the sample basket does not touch the sides.

A basket or container is also needed to contain sample while determining the suspended weight. This basket needs to be large enough to contain all of the sample pieces being tested. A basket constructed of a mesh-like material is recommended in order to reduce issues with water movement, however it is not necessary. Ideally, the spacing of the mesh should be small enough to support the samples effectively, but large enough that unneeded drag is not added to the basket. If the sample consists of a large number of pieces that are small, or oddly shaped, an additional wire mesh can be placed along the bottom to prevent any pieces from falling out of the basket.

Figure C-1 (below) shows the apparatus developed to complete this testing. As illustrated, the scale was placed on a desk over a twenty gallon plastic tub. A two inch hole was drilled through the desk in order to allow the basket to be suspended below the scale, and into the water. The sample basket was attached to the scale via four lengths of chain and a wire with a loop in the top. 


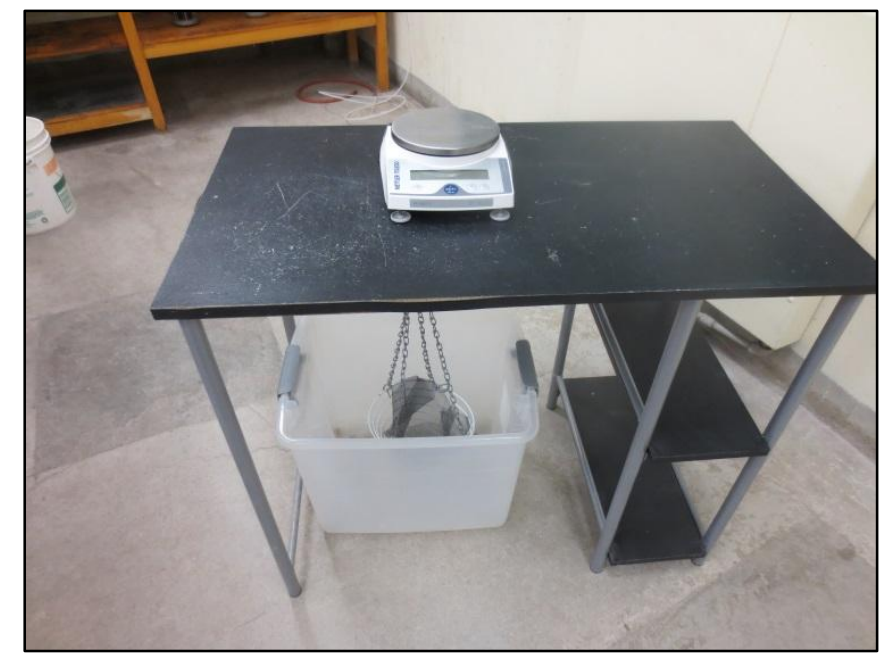

Figure C-1: Equipment set-up for completing the Instantaneous Water Immersion Testing. Not shown is the plastic shield used to shield the scale from any drafts in the lab during testing.

The tub was filled with water several hours prior to testing to allow the water to come to room temperature. This was necessary as the calculations for this method require that the specific gravity of the water be as close to one as possible. To check that the specific gravity of the sample was within an acceptable range, a $152 \mathrm{H}$ type hydrometer was used to check the density of the water with each trial.

To run an Instantaneous Water Immersion trial, the sample was first dried for 24 hours in a $110^{\circ} \mathrm{C}$ oven. After drying, the samples were allowed to sit for several hours in order to return to room temperature. The initial dry weight $(\mathrm{W})$ of the sample was recorded to the nearest .01 grams.

The suspended weight $\left(\mathrm{S}_{\mathrm{w}}\right)$ was then determined by suspending the sample in a wire basket under the scale. Care needs to be taken with this measurement, especially if the sample is highly permeable or contains large surface pores. As soon as the sample is placed into the liquid, water will start moving into the pores, causing a change in the suspended weight. It is therefore extremely important to record the weight quickly and accurately. Each weight measurement was recorded as soon as the scale came to rest on a number. Ensuring that the scale is properly calibrated at $0.0 \mathrm{~g}$, and minimizing the disturbance to the water when placing the sample in the basket, helped ensure a quick and accurate measurement. 
The volume of the sample was calculated by comparing the difference between the suspended weight, and the original dry weight of the sample. This relationship is based on the concept that a sample will displace a volume of water equal to the volume of the sample. Since water has a unique property that $1 \mathrm{~g}=1 \mathrm{~cm}^{3}=1 \mathrm{~mL}$ it can be determined that the volume of water displaced is also equal to the difference in the weight of the sample as long as the specific gravity of the fluid is equal to one (Laboratory Manual in Physical Geology, 2003).

Bulk density during this testing was calculated using the following equations:

$$
\mathrm{G}_{\mathrm{B}}=\frac{\mathrm{W}}{W-S_{W}}
$$

Where:

$$
\begin{aligned}
& G_{B}=\text { Bulk Density of the Sample in } \mathrm{g} / \mathrm{cm}^{3} \\
& W=\text { Dry Weight of the Sample in } \mathrm{g} \\
& S_{W}=\text { Suspended Weight of the sample, } g
\end{aligned}
$$

\section{Equipment Needed:}

Scale:

Capable of measuring to 0.01 grams and bottom loading to obtain the suspended weight of the sample.

Lab Table:

Needs to be level and stable to minimize any inaccuracy from being bumped while trying to obtain a suspended weight of the sample. A hole or some method of attaching the sample basket to the scale to obtain the sample weight needs to be drilled through the top of the desk. The hole needs to be large enough to keep the wire from touching the sides of the desk during testing.

Sample Basket: $\quad$ Basket or hook to place the sample inside while obtaining the suspended weight of the sample during the second phase of testing. Needs to be sturdy enough to completely contain the sample while trying to minimize the profile in the water as the larger the basket the longer it will take for the scale to come to rest after adding in the sample.

Water Tub: $\quad$ Needs to be deep enough to allow the sample to be suspended in the basket while still having the water cover the top. In this case a 20 gallon rubber tub was used. If the same water is to be used later 
a lid is advisable to keep any particles from falling into the water and contaminating the samples.

Hydrometer: $\quad$ Needed to check the specific gravity of the water to ensure that it is in fact at $1 \mathrm{~g} / \mathrm{cm}^{3}$. A $152 \mathrm{H}$ type hydrometer was used for this procedure.

Thermometer: $\quad$ Check that the water is at the needed range in temperature (20$23^{\circ} \mathrm{C}$ or room temperature).

Procedure:

1. Dry the sample at $110^{\circ} \mathrm{C}$ for a period of 24 hours \pm 4 hours. This will remove any trapped moisture from the interior of the sample and ensure that a true dry bulk density is achieved. After drying, allow the samples to return to room temperature prior to testing.

2. Determine the dry weight of the sample and record this weight as W.

3. Fill the water tub and set up the scale to be bottom loading. The water level in the tub should be deep enough to fully cover the sample in the basket. Allow the water to come to room temperature and then check that the water is at $20-23^{\circ} \mathrm{C}$ and at a specific gravity of approximately 1 .

4. Attach the sample basket to the bottom of the scale as shown in the diagram below. Make sure to tare the scale out prior to starting testing.

5. Place the sample into the basket and record the weight as the suspended weight (S).

6. Calculate the volume $(\mathrm{V})$ as the difference between the original dry weight, $\mathrm{W}$, and the suspended weight, $\mathrm{S}$.

7. Calculate the bulk density by diving the dry weight, $\mathrm{W}$, by the volume (V). 
Data:

Table B-1: Water Immersion Data for Rock Type 1: Granite

\begin{tabular}{|c|c|c|c|c|}
\hline Sample ID & $\begin{array}{c}\text { Dry Weight } \\
(\mathrm{g})\end{array}$ & $\begin{array}{c}\text { Suspended Weight } \\
(\mathrm{g})\end{array}$ & $\begin{array}{c}\text { Volume } \\
\left(\mathrm{cm}^{\wedge} 3\right)\end{array}$ & $\begin{array}{c}\text { Density } \\
\left(\mathrm{g} / \mathrm{cm}^{\wedge} 3\right)\end{array}$ \\
\hline $1-1-1$ & 704.13 & 434.48 & 269.65 & 2.61 \\
\hline $1-1-2$ & 466.41 & 287.28 & 179.13 & 2.60 \\
\hline $1-1-4$ & 444.2 & 273.89 & 170.31 & 2.61 \\
\hline
\end{tabular}

Table B-2: Water Immersion Data for Rock 2: Kona Dolomite

\begin{tabular}{|c|c|c|c|c|}
\hline Sample ID & $\begin{array}{c}\text { Dry Weight } \\
(\mathrm{g})\end{array}$ & $\begin{array}{c}\text { Suspended Weight } \\
(\mathrm{g})\end{array}$ & $\begin{array}{c}\text { Volume } \\
\left(\mathrm{cm}^{\wedge} 3\right)\end{array}$ & $\begin{array}{c}\text { Density } \\
\left(\mathrm{g} / \mathrm{cm}^{\wedge} 3\right)\end{array}$ \\
\hline $2-1-1$ & 508.48 & 316.57 & 191.91 & 2.65 \\
\hline $2-1-2$ & 490.97 & 310.24 & 180.73 & 2.72 \\
\hline $2-1-3$ & 510.81 & 321.89 & 188.92 & 2.70 \\
\hline $2-1-4$ & 511.9 & 320.86 & 191.04 & 2.68 \\
\hline $2-2-1$ & 536.04 & 353.29 & 182.75 & 2.93 \\
\hline $2-2-2$ & 518.21 & 331.68 & 186.53 & 2.78 \\
\hline $2-2-3$ & 532.21 & 346.35 & 185.86 & 2.86 \\
\hline $2-2-4$ & 502.88 & 223.15 & 279.73 & 1.80 \\
\hline $2-2-5$ & 502 & 328.52 & 173.48 & 2.89 \\
\hline $2-2-6$ & 505.3 & 316.74 & 188.56 & 2.68 \\
\hline
\end{tabular}

Table B-3: Water Immersion Data for Rock 3: Pelkie Dolomite

\begin{tabular}{|c|c|c|c|c|}
\hline Sample ID & $\begin{array}{c}\text { Dry Weight } \\
(\mathrm{g})\end{array}$ & $\begin{array}{c}\text { Suspended Weight } \\
(\mathrm{g})\end{array}$ & $\begin{array}{c}\text { Volume } \\
(\mathrm{cm})\end{array}$ & $\begin{array}{c}\text { Density } \\
\left(\mathrm{g} / \mathrm{cm}^{\wedge} 3\right)\end{array}$ \\
\hline $3-2-1$ & 276.34 & 170.6 & 105.74 & 2.61 \\
\hline $3-3-1$ & 338.87 & 216.48 & 122.39 & 2.77 \\
\hline
\end{tabular}


Table B-4: Water Immersion Data for Rock 4: Various Carbonates

\begin{tabular}{|c|c|c|c|c|}
\hline Sample ID & $\begin{array}{c}\text { Dry Weight } \\
(\mathrm{g})\end{array}$ & $\begin{array}{c}\text { Suspended Weight } \\
(\mathrm{g})\end{array}$ & $\begin{array}{c}\text { Volume } \\
\left(\mathrm{cm}^{\wedge} 3\right)\end{array}$ & $\begin{array}{c}\text { Density } \\
\left(\mathrm{g} / \mathrm{cm}^{\wedge} 3\right)\end{array}$ \\
\hline $4-1-1$ & 488.59 & 312.98 & 175.61 & 2.78 \\
\hline $4-1-2$ & 491.54 & 315.89 & 175.65 & 2.80 \\
\hline $4-1-3$ & 646.64 & 410.98 & 235.66 & 2.74 \\
\hline $4-1-4$ & 794.7 & 507.62 & 287.08 & 2.77 \\
\hline $4-1-5$ & 469.03 & 299.48 & 169.55 & 2.77 \\
\hline $4-2-1$ & 448.66 & 282.68 & 165.98 & 2.70 \\
\hline $4-2-2$ & 470.51 & 295.16 & 175.35 & 2.68 \\
\hline $4-2-3$ & 478.35 & 298.23 & 180.12 & 2.66 \\
\hline $4-3-1$ & 216.87 & 139.82 & 77.05 & 2.81 \\
\hline $4-3-2$ & 361.55 & 229.2 & 132.35 & 2.73 \\
\hline $4-3-3$ & 331.67 & 210.92 & 120.75 & 2.75 \\
\hline $4-4-1$ & 343.57 & 215.07 & 128.5 & 2.67 \\
\hline $4-4-2$ & 412.28 & 258.77 & 153.51 & 2.69 \\
\hline $4-4-3$ & 381 & 238.7 & 142.3 & 2.68 \\
\hline $4-5-1$ & 594.72 & 374.92 & 219.8 & 2.71 \\
\hline
\end{tabular}

Table B-5: Water Immersion Data for Rock 5: Water Cooled Blast Slag

\begin{tabular}{|c|c|c|c|c|}
\hline $\begin{array}{c}\text { Sample } \\
\text { ID }\end{array}$ & Dry Weight $(\mathrm{g})$ & $\begin{array}{c}\text { Suspended } \\
\text { Weight }(\mathrm{g})\end{array}$ & Volume $\left(\mathrm{cm}^{\wedge} 3\right)$ & $\begin{array}{c}\text { Density } \\
(\mathrm{g} / \mathrm{cm} \wedge\end{array}$ \\
\hline $5-1-1$ & 419.45 & 244.82 & 174.63 & 2.40 \\
\hline $5-1-2$ & 417.68 & 246.91 & 170.77 & 2.45 \\
\hline $5-1-3$ & 433.6 & 253.16 & 180.44 & 2.40 \\
\hline $5-1-4$ & 425.85 & 250.68 & 175.17 & 2.43 \\
\hline $5-1-5$ & 395.09 & 232.25 & 162.84 & 2.43 \\
\hline $5-2-1$ & 366.86 & 198.23 & 168.63 & 2.18 \\
\hline $5-2-2$ & 451.21 & 273.34 & 177.87 & 2.54 \\
\hline $5-2-3$ & 555.89 & 327.53 & 228.36 & 2.43 \\
\hline $5-2-5$ & 320.71 & 168.54 & 152.17 & 2.11 \\
\hline $5-3-1$ & 390.24 & 218.34 & 171.9 & 2.27 \\
\hline $5-3-2$ & 366.65 & 197.37 & 169.28 & 2.17 \\
\hline $5-3-3$ & 349.58 & 181.66 & 167.92 & 2.08 \\
\hline
\end{tabular}


Table B-6: Water Immersion Data for Rock 6: Jacobsville Sandstone

\begin{tabular}{|c|c|c|c|c|}
\hline $\begin{array}{c}\text { Sample } \\
\text { ID }\end{array}$ & Dry Weight $(\mathrm{g})$ & $\begin{array}{c}\text { Suspended } \\
\text { Weight }(\mathrm{g})\end{array}$ & Volume $\left(\mathrm{cm}^{\wedge} 3\right)$ & $\begin{array}{c}\text { Density } \\
\left(\mathrm{g} / \mathrm{cm}^{\wedge} 3\right)\end{array}$ \\
\hline $6-1-1$ & 378.78 & 204.82 & 173.96 & 2.18 \\
\hline $6-1-2$ & 374.96 & 203.29 & 171.67 & 2.18 \\
\hline $6-1-3$ & 372.41 & 200.64 & 171.77 & 2.17 \\
\hline $6-1-4$ & 376.79 & 202.96 & 173.83 & 2.17 \\
\hline $6-1-5$ & 382.72 & 204.32 & 178.4 & 2.15 \\
\hline $6-1-6$ & 371.65 & 200.56 & 171.09 & 2.17 \\
\hline $6-1-7$ & 387.54 & 208.52 & 179.02 & 2.16 \\
\hline $6-1-8$ & 379.23 & 204.42 & 174.81 & 2.17 \\
\hline $6-1-9$ & 380.39 & 204.62 & 175.77 & 2.16 \\
\hline $6-1-10$ & 377.17 & 202.18 & 174.99 & 2.16 \\
\hline $6-1-11$ & 382.86 & 205.32 & 177.54 & 2.16 \\
\hline $6-1-12$ & 377.37 & 203.34 & 174.03 & 2.17 \\
\hline
\end{tabular}

Table B-7: Water Immersion Data for Rock 7: Air Cooled Blast Slag

\begin{tabular}{|c|c|c|c|c|}
\hline $\begin{array}{c}\text { Sample } \\
\text { ID }\end{array}$ & Dry Weight $(\mathrm{g})$ & $\begin{array}{c}\text { Suspended } \\
\text { Weight }(\mathrm{g})\end{array}$ & Volume $\left(\mathrm{cm}^{\wedge} 3\right)$ & $\begin{array}{c}\text { Density } \\
(\mathrm{g} / \mathrm{cm} \wedge\end{array}$ \\
\hline $7-1$ & 450.35 & 251.81 & 198.54 & 2.27 \\
\hline $7-2$ & 432.68 & 242.55 & 190.13 & 2.37 \\
\hline $7-3$ & 422.49 & 235.06 & 187.43 & 2.31 \\
\hline $7-4$ & 320.59 & 130.46 & 190.13 & 2.22 \\
\hline $7-5$ & 459.83 & 260.58 & 199.25 & 2.31 \\
\hline $7-6$ & 380.55 & 181.30 & 199.25 & 1.91 \\
\hline $7-7$ & 566.06 & 302.78 & 263.28 & 2.15 \\
\hline $7-8$ & 434.34 & 249.21 & 185.13 & 2.35 \\
\hline
\end{tabular}


Table B-8: Re- Testing of $25 \%$ of samples for QA/QC

\begin{tabular}{|c|c|c|c|c|c|}
\hline Rock Type & $\begin{array}{l}\text { Sample } \\
\text { ID }\end{array}$ & $\begin{array}{l}\text { Dry Weight } \\
\text { (g) }\end{array}$ & $\begin{array}{l}\text { Suspended Weight } \\
(\mathrm{g})\end{array}$ & $\begin{array}{l}\text { Volume } \\
\left(\mathrm{cm}^{\wedge} 3\right)\end{array}$ & $\begin{array}{l}\text { Density } \\
\left(\mathrm{g} / \mathrm{cm}^{\wedge} 3\right)\end{array}$ \\
\hline Granite & $1-1-2$ & 466.41 & 291.43 & 174.98 & 2.67 \\
\hline $\begin{array}{c}\text { Kona } \\
\text { Dolomite }\end{array}$ & $2-1-3$ & 510.85 & 326.13 & 184.72 & 2.77 \\
\hline $\begin{array}{l}\text { Pelkie } \\
\text { Dolomite }\end{array}$ & $3-3-1$ & 338.88 & 216.18 & 122.70 & 2.76 \\
\hline \multirow{4}{*}{$\begin{array}{l}\text { Various } \\
\text { Carbonates }\end{array}$} & $4-1-2$ & 491.53 & 315.45 & 176.08 & 2.79 \\
\hline & $4-1-5$ & 469.03 & 300.72 & 168.31 & 2.79 \\
\hline & $4-3-2$ & 361.56 & 230.82 & 130.74 & 2.77 \\
\hline & $4-5-1$ & 594.53 & 372.12 & 222.41 & 2.67 \\
\hline \multirow{4}{*}{$\begin{array}{c}\text { Water } \\
\text { Cooled } \\
\text { Blast Slag }\end{array}$} & $5-1-1$ & 419.28 & 242.68 & 176.60 & 2.37 \\
\hline & $5-1-5$ & 341.78 & 200.25 & 141.53 & 2.41 \\
\hline & $5-2-1$ & 366.54 & 198.43 & 168.11 & 2.18 \\
\hline & $5-3-1$ & 390.38 & 220.83 & 169.55 & 2.30 \\
\hline \multirow{3}{*}{$\begin{array}{l}\text { Jacobsville } \\
\text { Sandstone }\end{array}$} & $6-1-1$ & 379.47 & 205.89 & 173.58 & 2.19 \\
\hline & $6-1-10$ & 377.81 & 203.58 & 174.23 & 2.17 \\
\hline & $6-1-11$ & 383.68 & 206.41 & 177.27 & 2.16 \\
\hline \multirow{2}{*}{$\begin{array}{l}\text { Air Cooled } \\
\text { Blast Slag }\end{array}$} & $7-2$ & 432.68 & 244.83 & 187.85 & 2.30 \\
\hline & $7-8$ & 434.34 & 258.61 & 175.73 & 2.47 \\
\hline
\end{tabular}


Table B-9: Comparison of Re-Tested Values to Original Values

\begin{tabular}{|c|c|c|c|c|}
\hline Rock Type & Sample ID & $\begin{array}{c}\text { Original Water } \\
\text { Immersion Density } \\
\left(\mathrm{g} / \mathrm{cm}^{\wedge} 3\right)\end{array}$ & $\begin{array}{c}\text { QA/QC Water } \\
\text { Immersion Density } \\
\left(\mathrm{g} / \mathrm{cm}^{\wedge} 3\right)\end{array}$ & $\begin{array}{c}\text { Percent Difference } \\
(\%)\end{array}$ \\
\hline Granite & $1-1-2$ & 2.61 & 2.67 & -1.49 \\
\hline $\begin{array}{c}\text { Kona } \\
\text { Dolomite }\end{array}$ & $2-1-3$ & 2.71 & 2.77 & -1.80 \\
\hline $\begin{array}{c}\text { Pelkie } \\
\text { Dolomite }\end{array}$ & $3-3-1$ & 2.77 & 2.76 & 0.29 \\
\hline $\begin{array}{c}\text { Various } \\
\text { Carbonates }\end{array}$ & $4-1-2$ & 2.8 & 2.79 & 0.30 \\
\cline { 2 - 5 } & $4-1-5$ & 2.77 & 2.79 & -0.60 \\
\cline { 2 - 5 } & $4-3-2$ & 2.73 & 2.77 & -1.45 \\
\cline { 2 - 5 } & $4-5-1$ & 2.71 & 2.67 & 1.37 \\
\hline Water & $5-1-1$ & 2.4 & 2.37 & 1.08 \\
\cline { 2 - 5 } Cooled & $5-1-5$ & 2.43 & 2.41 & 0.62 \\
\cline { 2 - 5 } Blast Slag & $5-2-1$ & 2.18 & 2.18 & -0.02 \\
\cline { 2 - 5 } & $5-3-1$ & 2.27 & 2.30 & -1.42 \\
\hline Jacobsville & $6-1-1$ & 2.18 & 2.19 & -0.28 \\
\cline { 2 - 5 } Sandstone & $6-1-10$ & 2.16 & 2.17 & -0.39 \\
\cline { 2 - 5 } & $6-1-11$ & 2.16 & 2.16 & -0.20 \\
\hline Air Cooled & $7-2$ & 2.37 & 2.30 & 2.85 \\
\cline { 2 - 5 } Blast Slag & $7-8$ & 2.35 & -5.05 \\
\hline
\end{tabular}




\section{Appendix D: Wax Immersion Results and Procedures}

One of the major issues with the Instantaneous water Immersion method is water entering the surface and internal pores of the sample during the testing process. This alters the volume calculation. One course of action which avoids this issue was to coat the sample in a layer of paraffin wax, sealing off the sample from the water. Since there is no current aggregate or mining industry standard procedure for this method, ASTM C 914-95: Standard Test Method for Bulk Density and Volume of Solid Refractories by Wax Immersion was used to as a model procedure (ASTM, 2004). This test method is for the determination of bulk density for any refractory or irregular shape in the construction industry, by coating the sample in a thin even layer of wax, and then conducting a water immersion trial. Two deviations were made to the procedure of this method. The first, was that the weights were recorded to 0.01 grams instead of the $0.1 \mathrm{~g}$ suggested by the ASTM. Secondly, the samples were suspended in a wire basket and not a loop of AWG wire copper wire.

The major advantage of using this method is that samples with a large surface pore volume, or high permeability, are not affected adversely by excess water entering the sample. This means that while calculating the suspended weight of the sample there is no rush to obtain the suspended weight. Any sample which is composed of multiple pieces can be coated individually, which mitigates any issues from samples which are broken or irregular.

However, there is a potential disadvantage when coating the entire sample in wax. The wax enters all exposed pore space of the sample, and can be very difficult to remove completely. If any other testing needs to be done that requires the sample to not be coated in wax this could cause potential issues.

This method utilizes the same general set up as the Instantaneous Water Immersion method, the only addition is a wax pot and paraffin wax. The scale, again, needs to be capable of bottom loading to obtain the suspended weight of the sample. A pot capable of melting wax and keeping it at a consistent temperature is also needed. In this case, a wax pot manufactured by Waage was used. As recommended by ASTM C 914-94 the wax used was a paraffin wax that melted at approximately $135^{\circ} \mathrm{F}\left(57^{\circ} \mathrm{C}\right)$ and has a density of 0.87 to $0.91 \mathrm{~g} / \mathrm{cm}^{3}$ (ASTM, 2004). This wax maintained a stable density despite repeatedly melting and solidifying. The wax used was manufactured by Scholar Chemistry. Both the wax pot used and a sample of the un-melted paraffin wax are shown below in D-1 below. 


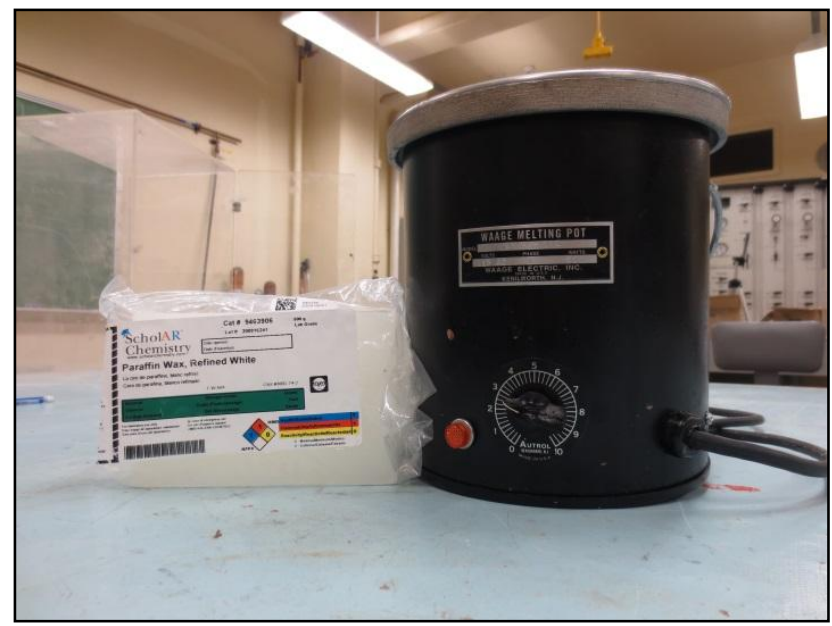

Figure D-1: Pictures of the wax pot and paraffin wax used during wax immersion testing

Again, prior to testing, all samples were dried for a period of 24 hours in a $110^{\circ} \mathrm{C}$ oven to remove any entrapped moisture from the sample and then allowed to cool to room temperature for several hours prior to starting testing.

The initial dry weight of the sample was then determined to 0.01 grams and recorded as $\mathrm{W}$. The wax was melted in the pot to approximately $135^{\circ} \mathrm{F}$ and the temperature of the wax was monitored throughout testing to ensure that the pot stayed between $130^{\circ} \mathrm{F}$ and $140^{\circ} \mathrm{F} .130^{\circ}$ $140^{\circ}$ is an ideal temperature, since wax at higher or lower temperatures will not stick to the sample as efficiently. Care was taken especially to avoid the higher temperatures while testing, as the wax would not form a thick enough coating on the sample.

To coat the sample, the core was held by one end, and the other end was dipped into the wax. The sample was then slowly removed from the wax and allowed to solidify prior to placing the sample on a flat surface. In the event that any air bubbles became trapped under the wax, they were pressed out of the wax while it was still warm, and if needed any holes in the wax were coated in an additional layer of wax.

After coating the sample in wax and allowing it to harden the sample was weighed again. The weight of the sample and the wax coating was recorded as $P$, to follow the system outlined in the ASTM. The sample was then immersed in water and the suspended weight of the sample was determined and recorded as $S_{\text {WAX. }}$ In the ASTM, this weight was simply $\mathrm{S}$, however it was changed to avoid confusion between suspended weights from different methods. Prior to starting any testing with the suspended weights, the temperature of the 
water was tested to ensure that it was approximately $22^{\circ} \mathrm{C}$ and has a specific gravity of one (which was tested by a $152 \mathrm{H}$ Hydrometer) (ASTM, 2004).

Several times throughout testing and after the addition of any new wax to the pot a sample of wax was removed from the pot and allowed to solidify. The density of this sample was then determined through the use of a Helium Pycnometer and recorded as $\mathrm{K}_{\mathrm{WAX}}$.

The volume of the sample was determined through two steps. The first was to calculate the total volume of the sample including the wax coating. This was identified as $V_{1}$ in the ASTM and $V_{S W}$ below and in the data. This equation makes a similar assumption to that of the Instantaneous Water Immersion method that the specific gravity of the water was equal to 1 (ASTM, 2004).

$$
V_{S W}=P-S_{W A X}
$$

Where:

$\mathrm{V}_{\mathrm{SW}}=$ Volume of the Sample with wax coating, $\mathrm{cm}^{3}$

$\mathrm{P}=$ Weight of Sample coated in wax, $\mathrm{g}$

$\mathrm{S}_{\mathrm{WAX}}=$ Suspended weight of coated sample, $g$

Next, the volume of just the wax coating was calculated. This is known as $\mathrm{V}_{\text {WAX }}$ in this document, but is referred to as $\mathrm{V}_{2}$ in ASTM C 914-95 (ASTM, 2004).

$$
V_{W A X}=\frac{P-W}{K_{W A X}}
$$

Where:

$\mathrm{V}_{\mathrm{WAX}}=$ Volume of Wax Coating, $\mathrm{cm}^{3}$

$\mathrm{P}=$ Weight of Sample coated in wax, $\mathrm{g}$

$\mathrm{W}=$ Weight of dried Sample, $\mathrm{g}$

$K_{W A X}=$ Density of the wax in $\mathrm{g} / \mathrm{cm}^{3}$ 
The overall volume, $\mathrm{V}$, of the sample was simply the difference between the total volume of the sample with the wax coating $\left(\mathrm{V}_{S W}\right)$ and the wax coating $\left(\mathrm{V}_{\mathrm{WAX}}\right)$ (ASTM, 2004).

$$
\begin{aligned}
& V=V_{S W}-V_{W A X} \\
& \text { Where: } \\
& \mathrm{V}=\text { Volume of Sample, } \mathrm{cm}^{3} \\
& \mathrm{~V}_{\mathrm{SW}}=\text { Volume Sample with Wax Coating, } \mathrm{cm}^{3} \\
& V_{\text {WAX }}=\text { Volume of Wax Coating, } \mathrm{cm}^{3}
\end{aligned}
$$

Finally the bulk density of the sample was calculated out to be the original sample weight $\mathrm{W}$, divided by sample volume (V) (ASTM, 2004).

$$
\mathrm{G}_{\mathrm{B}}=\frac{\mathrm{W}}{V}
$$

Where:

$\mathrm{G}_{\mathrm{B}}=$ Bulk Density of the Sample, $\mathrm{g} / \mathrm{cm}^{3}$

$\mathrm{W}=$ Dry Weight of the Sample, $\mathrm{g}$

$\mathrm{V}=$ Sample Volume, $\mathrm{cm}^{3}$ 
This procedure and equipment needs are based in part off of ASTM C 914-65: Standard Test Method for Bulk Density and Volume of Solid Refractories by Wax Immersion (ASTM, 2004).

Equipment Needed:

Scale:

Capable of measuring to 0.01 grams and bottom loading to obtain the suspended weight of the sample.

Lab Table:

Needs to be level and stable to minimize any wobbling from being bumped while trying to obtain a suspended weight of the sample. A hole or some method of attaching the sample basket to the scale to obtain the sample weight needs to be drilled through the top of the desk. The hole needs to be large enough to keep the wire from touching the sides of the desk during testing.

Sample Basket: $\quad$ Basket or hook to place the sample inside while obtaining the suspended weight of the sample during the second phase of testing. Needs to be sturdy enough to completely contain the sample while trying to minimize the profile in the water as the larger the basket the longer it will take for the scale to come to rest after adding in the sample.

Water Tub: $\quad$ Needs to be deep enough to allow the sample to be suspended in the basket while still having the water cover the top. In this case, a 20 gallon rubber tub was used. If the same water is to be used later a lid is advisable to keep any particles from falling into the water and contaminating the samples.

Hydrometer: $\quad$ Needed to check the specific gravity of the water to ensure that it is in fact at $1 \mathrm{~g} / \mathrm{cm}^{3}$. A $152 \mathrm{H}$ type hydrometer was used for this procedure.

Thermometer: $\quad$ Check that the water is at the needed range in temperature (20$23^{\circ} \mathrm{C}$ or room temperature).

Paraffin Wax: $\quad$ Needs to be a lab grade paraffin wax that melts at about $135^{\circ} \mathrm{F}$ $\left(57^{\circ} \mathrm{C}\right)$ and has a density of $0.87-0.91 \mathrm{~g} / \mathrm{cm}^{3}$.

Wax Pot:

Needs to heat the wax to an even and consistent temperature between 130 and 140 degrees. Vapors given off by melting wax can ignite at high temperatures. The pot should have a method of controlling the temperature to keep the wax at the optimum temperature. 
Procedure:

8. Dry the sample at $110^{\circ} \mathrm{C}$ for a period of 24 hours \pm 4 hours. This will remove any trapped moisture from the interior of the sample and ensure that a true dry bulk density is achieved. After drying, allow the samples to return to room temperature prior to testing.

9. Determine the dry weight of the sample and record this weight as $\mathrm{W}$.

10. Melt the wax in the pot and take a sample to be used during testing to determine its density.

11. Dip the sample into the wax pot to coat the sample. The best method for coating the sample is to hold one end of the sample and dip the other half of the sample into the wax. Slowly remove the sample from the wax and allow the wax to harden on the sample. If any air bubbles were trapped in the wax carefully push them out and apply an extra coating of wax, if needed, to cover any holes in the wax. Then, invert the sample and dip the other end, making sure to overlap the two wax layers.

12. Weigh the sample again and record the weight as $P$.

13. Fill the water tub and set up the scale to be bottom loading. The water level in the tub should be deep enough to fully cover the sample in the basket. Allow the water to come to room temperature and then check that the water is at $20-23^{\circ} \mathrm{C}$ and at a specific gravity of approximately 1 .

14. Attach the sample basket to the bottom of the scale as shown in the diagram below. Make sure to tare the scale prior to beginning testing and allow the scale to come to a complete rest before taking the measurement.

15. Place the sample into the basket and record the weight as the suspended weight (S SAX).

16. Calculate the volume $(\mathrm{V})$ as the difference between the original dry weight, $\mathrm{W}$, and the suspended weight, $\mathrm{S}_{\text {wax. }}$.

17. Calculate the bulk density by diving the dry weight, $\mathrm{W}$, by the volume ,V. 
Data:

Table D-1: Weight Results for the Granite Samples

\begin{tabular}{|c|c|c|c|}
\hline $\begin{array}{c}\text { Sample } \\
\text { ID }\end{array}$ & $\begin{array}{c}\text { Dry Weight } \\
(\mathrm{g})\end{array}$ & $\begin{array}{c}\text { Wax Coated Weight } \\
(\mathrm{g})\end{array}$ & $\begin{array}{c}\text { Suspended Weight } \\
(\mathrm{g})\end{array}$ \\
\hline $1-1-1$ & 704.11 & 714.88 & 436.49 \\
\hline $1-1-2$ & 466.39 & 473.84 & 289.75 \\
\hline $1-1-4$ & 444.13 & 451.26 & 276.09 \\
\hline
\end{tabular}

Table D-2: Volume and Density Calculations for the Granite Samples

\begin{tabular}{|c|c|c|c|c|}
\hline $\begin{array}{c}\text { Sample } \\
\text { ID }\end{array}$ & $\begin{array}{c}\text { Total Volume } \\
\left(\mathrm{cm}^{\wedge} 3\right)\end{array}$ & $\begin{array}{c}\text { Volume Wax } \\
\left(\mathrm{cm}^{\wedge} 3\right)\end{array}$ & $\begin{array}{c}\text { Sample Volume } \\
\left(\mathrm{cm}^{\wedge} 3\right)\end{array}$ & $\begin{array}{c}\text { Density } \\
\left(\mathrm{g} / \mathrm{cm}^{\wedge} 3\right)\end{array}$ \\
\hline $1-1-1$ & 278.39 & 11.97 & 266.42 & 2.64 \\
\hline $1-1-2$ & 184.09 & 8.28 & 175.81 & 2.65 \\
\hline $1-1-4$ & 175.17 & 7.93 & 167.24 & 2.66 \\
\hline
\end{tabular}

Table D-3: Weight Results for the Kona Dolomite Samples

\begin{tabular}{|c|c|c|c|}
\hline $\begin{array}{c}\text { Sample } \\
\text { ID }\end{array}$ & $\begin{array}{c}\text { Dry Weight } \\
(\mathrm{g})\end{array}$ & $\begin{array}{c}\text { Wax Coated Weight } \\
(\mathrm{g})\end{array}$ & $\begin{array}{c}\text { Suspended Weight } \\
(\mathrm{g})\end{array}$ \\
\hline $2-1-1$ & 508.51 & 515.54 & 318.70 \\
\hline $2-1-2$ & 491.04 & 497.30 & 308.93 \\
\hline $2-1-3$ & 510.86 & 517.42 & 324.20 \\
\hline $2-1-4$ & 511.93 & 519.52 & 322.80 \\
\hline $2-2-1$ & 536.08 & 542.25 & 348.35 \\
\hline $2-2-2$ & 518.27 & 524.64 & 331.05 \\
\hline $2-2-3$ & 532.28 & 540.67 & 345.43 \\
\hline $2-2-4$ & 502.92 & 511.33 & 325.03 \\
\hline $2-2-5$ & 502.01 & 507.61 & 325.64 \\
\hline $2-2-6$ & 505.37 & 511.93 & 315.65 \\
\hline
\end{tabular}


Table D4: Volume and Density Calculations for the Kona Dolomite Samples

\begin{tabular}{|c|c|c|c|c|}
\hline $\begin{array}{c}\text { Sample } \\
\text { ID }\end{array}$ & $\begin{array}{c}\text { Total Volume } \\
\left(\mathrm{cm}^{\wedge} 3\right)\end{array}$ & $\begin{array}{c}\text { Volume Wax } \\
\left(\mathrm{cm}^{\wedge} 3\right)\end{array}$ & $\begin{array}{c}\text { Sample Volume } \\
\left(\mathrm{cm}^{\wedge} 3\right)\end{array}$ & $\begin{array}{c}\text { Density } \\
\left(\mathrm{g} / \mathrm{cm}^{\wedge} 3\right)\end{array}$ \\
\hline $2-1-1$ & 196.84 & 7.82 & 189.02 & 2.69 \\
\hline $2-1-2$ & 188.37 & 6.96 & 181.41 & 2.71 \\
\hline $2-1-3$ & 193.22 & 7.29 & 185.93 & 2.75 \\
\hline $2-1-4$ & 196.72 & 8.44 & 188.28 & 2.72 \\
\hline $2-2-1$ & 193.90 & 6.86 & 187.04 & 2.87 \\
\hline $2-2-2$ & 193.59 & 7.08 & 186.51 & 2.78 \\
\hline $2-2-3$ & 195.24 & 9.33 & 185.91 & 2.86 \\
\hline $2-2-4$ & 186.30 & 9.35 & 176.95 & 2.84 \\
\hline $2-2-5$ & 181.97 & 6.23 & 175.74 & 2.86 \\
\hline $2-2-6$ & 196.28 & 7.29 & 188.99 & 2.67 \\
\hline
\end{tabular}

Table D-5: Weight Results for the Pelikie Dolomite Samples

\begin{tabular}{|c|c|c|c|}
\hline $\begin{array}{c}\text { Sample } \\
\text { ID }\end{array}$ & $\begin{array}{c}\text { Dry Weight } \\
(\mathrm{g})\end{array}$ & $\begin{array}{c}\text { Wax Coated Weight } \\
(\mathrm{g})\end{array}$ & $\begin{array}{c}\text { Suspended Weight } \\
(\mathrm{g})\end{array}$ \\
\hline $3-2-1$ & 257.71 & 262.18 & 161.30 \\
\hline $3-3-1$ & 338.92 & 344.47 & 214.61 \\
\hline
\end{tabular}

Table D-6: Volume and Density Calculations for the Pelkie Dolomite Samples

\begin{tabular}{|c|c|c|c|c|}
\hline $\begin{array}{c}\text { Sample } \\
\text { ID }\end{array}$ & $\begin{array}{c}\text { Total Volume } \\
\left(\mathrm{cm}^{\wedge} 3\right)\end{array}$ & $\begin{array}{c}\text { Volume Wax } \\
\left(\mathrm{cm}^{\wedge} 3\right)\end{array}$ & $\begin{array}{c}\text { Sample Volume } \\
\left(\mathrm{cm}^{\wedge} 3\right)\end{array}$ & $\begin{array}{c}\text { Density } \\
\left(\mathrm{g} / \mathrm{cm}^{\wedge} 3\right)\end{array}$ \\
\hline $3-2-1$ & 100.88 & 4.97 & 95.91 & 2.69 \\
\hline $3-3-1$ & 129.86 & 6.17 & 123.69 & 2.74 \\
\hline
\end{tabular}


Table D-7: Weight Results for the Various Carbonates Samples

\begin{tabular}{|c|c|c|c|}
\hline $\begin{array}{c}\text { Sample } \\
\text { ID }\end{array}$ & Dry Weight $(\mathrm{g})$ & Wax Coated Weight $(\mathrm{g})$ & $\begin{array}{c}\text { Suspended Weight } \\
(\mathrm{g})\end{array}$ \\
\hline $4-1-1$ & 456.27 & 465.61 & 290.84 \\
\hline $4-1-2$ & 491.55 & 500.20 & 313.22 \\
\hline $4-1-3$ & 646.71 & 661.03 & 408.87 \\
\hline $4-1-4$ & 794.70 & 807.79 & 504.95 \\
\hline $4-1-5$ & 469.04 & 476.94 & 298.68 \\
\hline $4-2-1$ & 448.43 & 456.88 & 280.52 \\
\hline $4-2-2$ & 454.38 & 463.23 & 283.75 \\
\hline $4-2-3$ & 478.42 & 487.17 & 296.52 \\
\hline $4-3-1$ & 196.10 & 199.06 & 124.16 \\
\hline $4-3-2$ & 361.86 & 366.64 & 228.89 \\
\hline $4-3-3$ & 331.67 & 336.25 & 209.70 \\
\hline $4-4-1$ & 343.95 & 349.79 & 214.40 \\
\hline $4-4-2$ & 412.35 & 419.34 & 255.29 \\
\hline $4-4-3$ & 381.22 & 390.47 & 237.48 \\
\hline $4-5-1$ & 594.59 & 609.06 & 370.88 \\
\hline
\end{tabular}

Table D-8: Volume and Density Calculations for the Various Carbonate Samples

\begin{tabular}{|c|c|c|c|c|}
\hline $\begin{array}{c}\text { Sample } \\
\text { ID }\end{array}$ & $\begin{array}{c}\text { Total Volume } \\
\left(\mathrm{cm}^{\wedge} 3\right)\end{array}$ & $\begin{array}{c}\text { Volume Wax } \\
\left(\mathrm{cm}^{\wedge} 3\right)\end{array}$ & $\begin{array}{c}\text { Sample Volume } \\
\left(\mathrm{cm}^{\wedge} 3\right)\end{array}$ & $\begin{array}{c}\text { Density } \\
\left(\mathrm{g} / \mathrm{cm}^{\wedge} 3\right)\end{array}$ \\
\hline $4-1-1$ & 174.77 & 10.38 & 164.39 & 2.78 \\
\hline $4-1-2$ & 186.98 & 9.62 & 177.36 & 2.77 \\
\hline $4-1-3$ & 252.16 & 15.92 & 236.24 & 2.74 \\
\hline $4-1-4$ & 302.84 & 14.55 & 288.29 & 2.76 \\
\hline $4-1-5$ & 178.26 & 8.78 & 169.48 & 2.77 \\
\hline $4-2-1$ & 176.36 & 9.40 & 166.96 & 2.69 \\
\hline $4-2-2$ & 179.48 & 9.84 & 169.64 & 2.68 \\
\hline $4-2-3$ & 190.65 & 9.73 & 180.92 & 2.64 \\
\hline $4-3-1$ & 74.90 & 3.29 & 71.61 & 2.74 \\
\hline $4-3-2$ & 137.75 & 5.31 & 132.44 & 2.73 \\
\hline $4-3-3$ & 126.55 & 5.09 & 121.46 & 2.73 \\
\hline $4-4-1$ & 135.39 & 6.49 & 128.90 & 2.67 \\
\hline $4-4-2$ & 164.05 & 7.77 & 156.28 & 2.64 \\
\hline $4-4-3$ & 152.99 & 10.28 & 142.71 & 2.67 \\
\hline $4-5-1$ & 238.18 & 16.09 & 222.09 & 2.68 \\
\hline
\end{tabular}


Table D-9: Weight Results for the Water Cooled Slag Samples

\begin{tabular}{|c|c|c|c|}
\hline $\begin{array}{c}\text { Sample } \\
\text { ID }\end{array}$ & Dry Weight $(\mathrm{g})$ & Wax Coated Weight $(\mathrm{g})$ & $\begin{array}{c}\text { Suspended Weight } \\
(\mathrm{g})\end{array}$ \\
\hline $5-1-1$ & 419.31 & 435.03 & 238.90 \\
\hline $5-1-2$ & 395.35 & 408.00 & 227.11 \\
\hline $5-1-3$ & 433.41 & 446.17 & 247.80 \\
\hline $5-1-4$ & 425.74 & 440.37 & 245.31 \\
\hline $5-1-5$ & 341.78 & 352.76 & 196.40 \\
\hline $5-2-1$ & 366.56 & 385.75 & 195.25 \\
\hline $5-2-2$ & 451.26 & 463.03 & 268.25 \\
\hline $5-2-3$ & 507.91 & 516.93 & 296.79 \\
\hline $5-2-5$ & 320.66 & 332.25 & 164.22 \\
\hline $5-3-1$ & 390.42 & 399.99 & 218.34 \\
\hline $5-3-2$ & 366.65 & 378.76 & 191.32 \\
\hline $5-3-3$ & 349.79 & 364.23 & 177.74 \\
\hline
\end{tabular}

Table D-10: Volume and Density Calculations for the Water Cooled Slag Samples

\begin{tabular}{|c|c|c|c|c|}
\hline $\begin{array}{c}\text { Sample } \\
\text { ID }\end{array}$ & $\begin{array}{c}\text { Total Volume } \\
\left(\mathrm{cm}^{\wedge} 3\right)\end{array}$ & $\begin{array}{c}\text { Volume Wax } \\
\left(\mathrm{cm}^{\wedge} 3\right)\end{array}$ & $\begin{array}{c}\text { Sample Volume } \\
\left(\mathrm{cm}^{\wedge} 3\right)\end{array}$ & $\begin{array}{c}\text { Density } \\
\left(\mathrm{g} / \mathrm{cm}^{\wedge} 3\right)\end{array}$ \\
\hline $5-1-1$ & 196.13 & 17.48 & 178.65 & 2.35 \\
\hline $5-1-2$ & 180.89 & 14.06 & 166.83 & 2.37 \\
\hline $5-1-3$ & 198.37 & 14.19 & 184.18 & 2.35 \\
\hline $5-1-4$ & 195.06 & 16.27 & 178.79 & 2.38 \\
\hline $5-1-5$ & 156.36 & 12.21 & 144.15 & 2.37 \\
\hline $5-2-1$ & 190.50 & 21.34 & 169.16 & 2.17 \\
\hline $5-2-2$ & 194.78 & 13.09 & 181.69 & 2.48 \\
\hline $5-2-3$ & 220.14 & 10.03 & 210.11 & 2.42 \\
\hline $5-2-5$ & 168.03 & 12.89 & 155.14 & 2.07 \\
\hline $5-3-1$ & 181.65 & 10.64 & 171.01 & 2.28 \\
\hline $5-3-2$ & 187.44 & 13.46 & 173.98 & 2.11 \\
\hline $5-3-3$ & 186.49 & 16.06 & 170.43 & 2.05 \\
\hline
\end{tabular}


Table D-11: Weight Results for the Jacobsville Sandstone Samples

\begin{tabular}{|c|c|c|c|}
\hline $\begin{array}{c}\text { Sample } \\
\text { ID }\end{array}$ & $\begin{array}{c}\text { Dry Weight } \\
(\mathrm{g})\end{array}$ & $\begin{array}{c}\text { Wax Coated Weight } \\
(\mathrm{g})\end{array}$ & $\begin{array}{c}\text { Suspended Weight } \\
(\mathrm{g})\end{array}$ \\
\hline $6-1-1$ & 379.37 & 384.99 & 201.62 \\
\hline $6-1-2$ & 375.55 & 381.28 & 199.93 \\
\hline $6-1-3$ & 372.99 & 378.42 & 197.09 \\
\hline $6-1-4$ & 377.33 & 382.55 & 200.02 \\
\hline $6-1-5$ & 383.33 & 388.97 & 201.98 \\
\hline $6-1-6$ & 372.19 & 377.69 & 197.07 \\
\hline $6-1-7$ & 388.10 & 393.60 & 205.82 \\
\hline $6-1-8$ & 379.36 & 385.61 & 200.78 \\
\hline $6-1-9$ & 380.66 & 386.40 & 201.42 \\
\hline $6-1-10$ & 377.71 & 383.07 & 198.90 \\
\hline $6-1-11$ & 383.57 & 389.42 & 202.58 \\
\hline $6-1-12$ & 377.89 & 383.59 & 200.46 \\
\hline
\end{tabular}

Table D-12: Volume and Density Calculations for the Jacobsville Sandstone Samples

\begin{tabular}{|c|c|c|c|c|}
\hline $\begin{array}{c}\text { Sample } \\
\text { ID }\end{array}$ & $\begin{array}{c}\text { Total Volume } \\
\left(\mathrm{cm}^{\wedge} 3\right)\end{array}$ & $\begin{array}{c}\text { Volume Wax } \\
\left(\mathrm{cm}^{\wedge} 3\right)\end{array}$ & $\begin{array}{c}\text { Sample Volume } \\
\left(\mathrm{cm}^{\wedge} 3\right)\end{array}$ & $\begin{array}{c}\text { Density } \\
\left(\mathrm{g} / \mathrm{cm}^{\wedge} 3\right)\end{array}$ \\
\hline $6-1-1$ & 183.37 & 6.25 & 177.12 & 2.14 \\
\hline $6-1-2$ & 181.35 & 6.37 & 174.98 & 2.15 \\
\hline $6-1-3$ & 181.33 & 6.04 & 175.29 & 2.13 \\
\hline $6-1-4$ & 182.53 & 5.80 & 176.73 & 2.14 \\
\hline $6-1-5$ & 186.99 & 6.27 & 180.72 & 2.12 \\
\hline $6-1-6$ & 180.62 & 6.12 & 174.50 & 2.13 \\
\hline $6-1-7$ & 187.78 & 6.12 & 181.66 & 2.14 \\
\hline $6-1-8$ & 184.83 & 6.95 & 177.88 & 2.13 \\
\hline $6-1-9$ & 184.98 & 6.38 & 178.60 & 2.13 \\
\hline $6-1-10$ & 184.17 & 5.96 & 178.21 & 2.12 \\
\hline $6-1-11$ & 186.84 & 6.50 & 180.34 & 2.13 \\
\hline $6-1-12$ & 183.13 & 6.34 & 176.79 & 2.14 \\
\hline
\end{tabular}


Table D-13: Weight Results for the Air Cooled Slag Samples

\begin{tabular}{|c|c|c|c|}
\hline Sample ID & Dry Weight $(\mathrm{g})$ & $\begin{array}{c}\text { Wax Coated Weight } \\
(\mathrm{g})\end{array}$ & $\begin{array}{c}\text { Suspended Weight } \\
(\mathrm{g})\end{array}$ \\
\hline $7-1$ & 384.08 & 397.64 & 207.97 \\
\hline $7-2$ & 349.10 & 358.94 & 194.40 \\
\hline $7-3$ & 344.15 & 354.23 & 184.45 \\
\hline $7-4$ & 320.63 & 337.69 & 149.07 \\
\hline $7-5$ & 384.47 & 395.64 & 215.32 \\
\hline $7-6$ & 380.56 & 390.26 & 203.98 \\
\hline $7-7$ & 480.11 & 497.64 & 246.04 \\
\hline $7-8$ & 354.03 & 367.14 & 196.20 \\
\hline
\end{tabular}

Table D-14: Volume and Density Calculations for the Air Cooled Slag Samples

\begin{tabular}{|c|c|c|c|c|}
\hline $\begin{array}{c}\text { Sample } \\
\text { ID }\end{array}$ & $\begin{array}{c}\text { Total Volume } \\
\left(\mathrm{cm}^{\wedge} 3\right)\end{array}$ & $\begin{array}{c}\text { Volume Wax } \\
\left(\mathrm{cm}^{\wedge} 3\right)\end{array}$ & $\begin{array}{c}\text { Sample Volume } \\
\left(\mathrm{cm}^{\wedge} 3\right)\end{array}$ & $\begin{array}{c}\text { Density } \\
\left(\mathrm{g} / \mathrm{cm}^{\wedge} 3\right)\end{array}$ \\
\hline $7-1$ & 189.67 & 15.08 & 174.59 & 2.20 \\
\hline $7-2$ & 164.54 & 10.94 & 153.60 & 2.27 \\
\hline $7-3$ & 169.78 & 11.21 & 158.57 & 2.17 \\
\hline $7-4$ & 188.62 & 18.97 & 169.65 & 1.89 \\
\hline $7-5$ & 180.32 & 12.42 & 167.90 & 2.29 \\
\hline $7-6$ & 186.28 & 10.78 & 175.50 & 2.17 \\
\hline $7-7$ & 251.60 & 19.49 & 232.11 & 2.07 \\
\hline $7-8$ & 170.94 & 14.58 & 156.36 & 2.26 \\
\hline
\end{tabular}

Table D-15: Granite Percentage by Weight of Wax Needed to Coat the Sample

\begin{tabular}{|c|c|}
\hline $\begin{array}{c}\text { Sample } \\
\text { ID }\end{array}$ & $\begin{array}{c}\text { Percent By Weight Wax To Coat } \\
\text { Sample } \\
(\%)\end{array}$ \\
\hline $1-1-1$ & 1.53 \\
\hline $1-1-2$ & 1.60 \\
\hline $1-1-4$ & 1.61 \\
\hline
\end{tabular}


Table D-16: Kona Dolomite Percentage by Weight of Wax Needed to Coat the Sample

\begin{tabular}{|c|c|}
\hline $\begin{array}{c}\text { Sample } \\
\text { ID }\end{array}$ & $\begin{array}{c}\text { Percent By Weight Wax To Coat } \\
\text { Sample } \\
(\%)\end{array}$ \\
\hline $2-1-1$ & 1.38 \\
\hline $2-1-2$ & 1.27 \\
\hline $2-1-3$ & 1.28 \\
\hline $2-1-4$ & 1.48 \\
\hline $2-2-1$ & 1.15 \\
\hline $2-2-2$ & 1.23 \\
\hline $2-2-3$ & 1.58 \\
\hline $2-2-4$ & 1.67 \\
\hline $2-2-5$ & 1.12 \\
\hline $2-2-6$ & 1.30 \\
\hline
\end{tabular}

Table D-17: Pelkie Dolomite Percentage by Weight of Wax Needed to Coat the Sample

\begin{tabular}{|c|c|}
\hline $\begin{array}{c}\text { Sample } \\
\text { ID }\end{array}$ & $\begin{array}{c}\text { Percent By Weight Wax To Coat } \\
\text { Sample } \\
(\%)\end{array}$ \\
\hline $3-2-1$ & 1.73 \\
\hline $3-3-1$ & 1.64 \\
\hline
\end{tabular}

Table D-18: Various Carbonates Percentage by Weight of Wax Needed to Coat the Sample

\begin{tabular}{|c|c|}
\hline $\begin{array}{c}\text { Sample } \\
\text { ID }\end{array}$ & $\begin{array}{c}\text { Percent By Weight Wax To Coat } \\
\text { Sample } \\
(\%)\end{array}$ \\
\hline $4-1-1$ & 2.05 \\
\hline $4-1-2$ & 1.76 \\
\hline $4-1-3$ & 2.21 \\
\hline $4-1-4$ & 1.65 \\
\hline $4-1-5$ & 1.68 \\
\hline $4-2-1$ & 1.88 \\
\hline $4-2-2$ & 1.95 \\
\hline $4-2-3$ & 1.83 \\
\hline $4-3-1$ & 1.51 \\
\hline $4-3-2$ & 1.32 \\
\hline $4-3-3$ & 1.38 \\
\hline $4-4-1$ & 1.70 \\
\hline $4-4-2$ & 1.70 \\
\hline $4-4-3$ & 2.43 \\
\hline $4-5-1$ & 2.43 \\
\hline
\end{tabular}


Table D-19: Water Cooled Slag Percentage by Weight of Wax Needed to Coat the Sample

\begin{tabular}{|c|c|}
\hline $\begin{array}{c}\text { Sample } \\
\text { ID }\end{array}$ & $\begin{array}{c}\text { Percent By Weight Wax To Coat } \\
\text { Sample } \\
(\%)\end{array}$ \\
\hline $5-1-1$ & 3.75 \\
\hline $5-1-2$ & 3.20 \\
\hline $5-1-3$ & 2.94 \\
\hline $5-1-4$ & 3.44 \\
\hline $5-1-5$ & 3.21 \\
\hline $5-2-1$ & 5.24 \\
\hline $5-2-2$ & 2.61 \\
\hline $5-2-3$ & 1.78 \\
\hline $5-2-5$ & 3.61 \\
\hline $5-3-1$ & 2.45 \\
\hline $5-3-2$ & 3.30 \\
\hline $5-3-3$ & 4.13 \\
\hline
\end{tabular}

Table D-20: Jacobsville Sandstone Percentage by Weight of Wax Needed to Coat the Sample

\begin{tabular}{|c|c|}
\hline $\begin{array}{c}\text { Sample } \\
\text { ID }\end{array}$ & $\begin{array}{c}\text { Percent By Weight Wax To Coat } \\
\text { Sample } \\
(\%)\end{array}$ \\
\hline $6-1-1$ & 1.48 \\
\hline $6-1-2$ & 1.53 \\
\hline $6-1-3$ & 1.46 \\
\hline $6-1-4$ & 1.38 \\
\hline $6-1-5$ & 1.47 \\
\hline $6-1-6$ & 1.48 \\
\hline $6-1-7$ & 1.42 \\
\hline $6-1-8$ & 1.65 \\
\hline $6-1-9$ & 1.51 \\
\hline $6-1-10$ & 1.42 \\
\hline $6-1-11$ & 1.53 \\
\hline $6-1-12$ & 1.51 \\
\hline
\end{tabular}


Table D-21: Air Cooled Slag Percentage by Weight of Wax Needed to Coat the Sample

\begin{tabular}{|c|c|}
\hline $\begin{array}{c}\text { Sample } \\
\text { ID }\end{array}$ & $\begin{array}{c}\text { Percent By Weight Wax To Coat } \\
\text { Sample } \\
(\%)\end{array}$ \\
\hline $7-1$ & 3.53 \\
\hline $7-2$ & 2.82 \\
\hline $7-3$ & 2.93 \\
\hline $7-4$ & 5.32 \\
\hline $7-5$ & 2.91 \\
\hline $7-6$ & 2.55 \\
\hline $7-7$ & 3.65 \\
\hline $7-8$ & 3.70 \\
\hline
\end{tabular}




\section{Appendix E: Wax-Shrink Wrap Immersion Results and Procedures}

The Shrink Wrap-Wax Method is a modification of the existing wax method as outlined in ASTM C914-95. This method adds an extra layer of shrink wrap surrounding the core, prior to the wax being applied, which acts as a barrier between the sample and the wax. Food grade plastic wrap was used to wrap the sample, and then a heat gun was used to seal the plastic.

This method has many of the same benefits as the wax method. First, the pore space is sealed off from the water during the suspended weight measurement. This means that no water can enter the pore space during the weight measurement, which allows for a more accurate reading, and is less dependent on the amount of time needed to take the reading. An additional benefit to this method is that the wax is not actually touching the core, and can be removed fairly easily by removing the plastic and wax together. If additional testing is required at a later date, the sample can be re-used with no wax remaining on the sample. The sample can also be re-tested for QA/QC purposes.

However, unlike the Wax Method the sample must be in fairly regular shapes in order for this method to work. It is very difficult to try to wrap irregular pieces in shrink wrap and still create a tight fit. If too much air is trapped around the sample, it could cause an increase in the volume of the sample, which would impact the density calculation.

With this method, care needs to be taken when using the heat gun to seal the sample. Applying to much heat in one area can cause the wrap to melt. Potentially ruining the sample, or destroying the saran wrap which could leave holes in the coating. This method has also not been tested extensively. By not having a historical record of use, there is the possibility of issues in accuracy arising, which have not yet been encountered.

Another disadvantage of this method is that unlike the Wax method, this method will not completely fill the exposed pore space. The shrink wrap will lay on top of the pore rather than filling the pore space. When the pores are small enough, the heat gun melting the wrap may be enough to fill the pore, however with larger pores there will be an air gap left in the bottom of the pore. A schematic of this issue is seen below in Figure E-1. In part (a) of the diagram the wax (grey) is coating the inside of the pore space (black). However when the shrink wrap (white) is added to the sample in part (b) there is a slight air gap left in the bottom of the pore. 


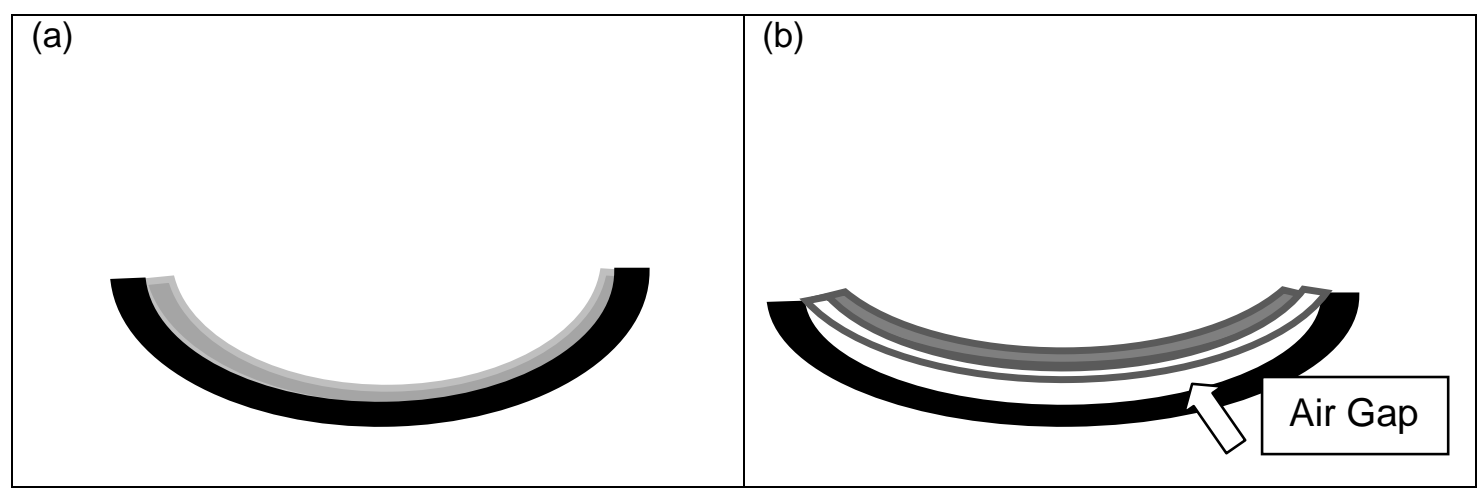

Figure E-1: Part (a) shows the wax (grey) coating the inside of the pore space (black). However when the shrink wrap (white) is added to the sample in part (b) there is a slight air gap left in the bottom of the pore.

As defined earlier, a bulk density is the density of a material that includes the internal void space of the sample, but not the surface pores. If it is possible to fully seal off the pore space with the shrink wrap during the heating process there will be minimal error in the density measurement. However if there are significant pores in terms of both depth or size, there can be significant error.

This method uses much the same procedure and equipment as outlined in Appendix D. Additionally, the heat gun and the saran wrap have been added. Food grade plastic wrap from Gordon Food Service that was 12 inches in width was used for these experiments. The lab bench, scale, and wax equipment used for this method were all the same as the Wax Method.

All samples were again dried in a $110^{\circ} \mathrm{C}$ oven overnight to remove any trapped moisture from the samples. After cooling to room temperature, the samples were tightly rolled in the shrink wrap. After rolling the sample in shrink wrap, the heat gun was used to seal the sample. This was done to keep the plastic in place, as well as keep the wax from working its way through the plastic and reaching the sample. Care was taken to ensure that the ends of the sample were fully sealed, and that as much of the pores were coated as possible.

After wrapping the sample, and sealing the core with the heat gun, the sample was coated in wax. Using the same methodology as before, the sample was coated by holding one end of the sample and coating the bottom half of the sample, allowing the sample to completely cool and then coating the other half of the sample. As noted in the earlier section, it was very important to keep the wax at a consistent temperature. The optimum temperature found for 
this test was approximately $135^{\circ} \mathrm{F}$. Due to the plastic coating on the sample, there was a potential for wax to be less likely to adhere, than if the sample were coated directly in wax. This was due to the smooth texture of the shrink wrap, at times, the sample needed to be dipped into the wax pot several times in order to ensure that the sample was fully coated.

Samples of the wax used, as well as the shrink wrap, were both placed into the Helium Pycnometer in order to determine the density of the materials. Both the density of the wax and the saran wrap, were needed in the determination of the bulk density of the sample.

This method is based off of four weights. The first, is the initial dry weight of the sample (W). The second weight determined, is the weight of the sample coated in the shrink wrap $\left(\mathrm{W}_{\mathrm{S}}\right)$. The third weight recorded was the weight of the sample with both the wax and shrink wrap layers $\left(\mathrm{W}_{\mathrm{WS}}\right)$, and finally the suspended weight of the sample $\left(\mathrm{S}_{\mathrm{WS}}\right)$.

The first calculation is the volume of the saran wrap coating on the sample. This is simply the difference between the weight of the saran wrapped sample and the dry weight of the sample, divided by the density of the saran wrap used. $\left(\mathrm{g} / \mathrm{cm}^{3}\right)$ This is known as $V_{S}$ in this document.

$$
V_{S}=\frac{W_{S}-W}{K_{S}}
$$

Where:

$$
\begin{aligned}
& V_{S}=\text { The volume of the shrink wrapped coating, } \mathrm{cm}^{3} \\
& W_{S}=\text { Weight of the sample coated in shrink wrap, } g \\
& W=\text { Weight of the dried sample, } g \\
& K_{S}=\text { Density of the shrink wrap, } \mathrm{g} / \mathrm{cm}^{3}
\end{aligned}
$$

Next, the volume of just the wax coating was calculated. This is known as $V_{\text {WAX }}$ in this document as with the Wax Immersion Method.

$$
V_{W A X}=\frac{W_{W S}-W_{S}}{K_{W A X}}
$$

Where:

$$
\begin{aligned}
& V_{\text {WAX }}=\text { Volume of Wax Coating, } \mathrm{cm}^{3} \\
& W_{W S}=\text { Sample coated in wax and shrink wrap, } g \\
& W_{S}=\text { Weight Sample with shrink wrap coating, } g \\
& K_{W A X}=\text { Density of the wax in } \mathrm{g} / \mathrm{cm}^{3}
\end{aligned}
$$


The next step is to determine the total volume of the core with both the shrink wrap and wax coating on the sample.

$$
V_{S S W}=W_{W S}-S_{W S}
$$

Where:

$\mathrm{V}_{\mathrm{SSW}}=$ Volume of the Sample with wax coating, $\mathrm{cm}^{3}$

$W_{\text {wS }}=$ Weight of Sample with wax +shrink wrap, $g$

$S_{W S}=$ Suspended weight of fully coated sample, $g$

The overall volume, $\mathrm{V}$, of the sample was simply the difference between the total volume of the sample with the wax and shrink wrap coatings $\left(\mathrm{V}_{\mathrm{Ssw}}\right)$, the volume of the shrink wrap $(\mathrm{V}$ and the wax coating ( $\left.\mathrm{V}_{\text {WAX }}\right)$.

$$
V=V_{S W}-V_{W A X}
$$

Where:

$$
\begin{aligned}
& V=\text { Volume of Sample, } \mathrm{cm}^{3} \\
& V_{S W}=\text { Volume Sample with Wax Coating, } \mathrm{cm}^{3} \\
& V_{\text {WAX }}=\text { Volume of Wax Coating, } \mathrm{cm}^{3}
\end{aligned}
$$

Finally, the bulk density of the sample was calculated to be the original sample weight $\mathrm{W}$, divided by sample volume (V).

$$
\mathrm{G}_{\mathrm{B}}=\frac{\mathrm{W}}{V}
$$

Where:

$$
\begin{aligned}
& G_{B}=\text { Bulk Density of the Sample, } \mathrm{g} / \mathrm{cm}^{3} \\
& W=\text { Dry Weight of the Sample, } \mathrm{g} \\
& V=\text { Sample Volume, } \mathrm{cm}^{3}
\end{aligned}
$$

The following sections fully detail the equipment needed and the procedures followed. 
Equipment Needed:

Scale:

Lab Table:

Sample Basket:

Water Tub:

Hydrometer:

Thermometer:

Paraffin Wax:

Wax Pot:

Shrink Wrap:

Heat Gun:
Capable of measuring to 0.01 grams and bottom loading to obtain the suspended weight of the sample.

Needs to be level and stable to minimize any wobbling from being bumped while trying to obtain a suspended weight of the sample. A hole or some method of attaching the sample basket to the scale to obtain the sample weight needs to be drilled through the top of the desk. The hole needs to be large enough to keep the wire from touching the sides of the desk during testing.

Basket or hook to place the sample inside while obtaining the suspended weight of the sample during the second phase of testing. Needs to be sturdy enough to completely contain the sample, while trying to minimize the profile in the water. The larger the basket, the longer it will take for the scale to come to rest after adding the sample.

Needs to be deep enough to allow the sample to be suspended in the basket, while still having the water cover the top. In this case a 20 gallon rubber tub was used. If the same water is to be used later, a lid is advisable to keep any particles from falling into the water and contaminating the samples.

Needed to check the specific gravity of the water to ensure that it is in fact at $1 \mathrm{~g} / \mathrm{cm}^{3}$. A $152 \mathrm{H}$ type hydrometer was used for this procedure.

Check that the water is at the needed range in temperature (20$23^{\circ} \mathrm{C}$ or room temperature).

Needs to be a lab grade paraffin wax that melts at approximately $135^{\circ} \mathrm{F}\left(57^{\circ} \mathrm{C}\right)$ and has a density of $0.87-0.91 \mathrm{~g} / \mathrm{cm}^{3}$.

Needs to heat the wax to an even and consistent temperature between $130^{\circ}$ and $140^{\circ}$. Vapors given off by melting wax can ignite at high temperatures. The pot should have a method of controlling the temperature to keep the wax at the optimum temperature.

Needs to be long/wide enough to completely wrap the sample.

Any readily available heat gun should work for this test. Multiple temperature settings are recommended. A 1200 Watt heat gun capable of reaching a temperature of $750^{\circ} \mathrm{C}$ was used for this testing.

Procedure: 
18. Dry the sample at $110^{\circ} \mathrm{C}$ for a period of 24 hours \pm 4 hours. This will remove any trapped moisture from the interior of the sample and ensure that a true dry bulk density is achieved. After drying, allow the samples to return to room temperature prior to testing.

19. Determine the dry weight of the sample and record this weight as W.

20. Take a sample of the shrink wrap and determine its density using a helium pycnometer.

21. Wrap the sample in the shrink wrap. To seal off the edges, they should be tucked under the sample prior to rolling the sample

22. Melt the wax in the pot, and take a sample to be used in testing to determine its density.

23. Dip the sample into the wax pot to coat the sample. The best method for coating the sample is, to hold one end of the sample and dip the other half of the sample into the wax. Slowly remove the sample from the wax and allow the wax to harden on the sample. If any air bubbles were trapped in the wax, carefully push them out and apply an extra coating of wax, if needed, to cover any holes in the wax. Then, invert the sample, and dip the other end making sure to overlap the two wax layers.

24. Weigh the sample again and record the weight as $P$.

25. Fill the water tub and set up the scale to be bottom loading. The water level in the tub should be deep enough to fully cover the sample in the basket. Allow the water to come to room temperature and then check that the water is approximately 20$23^{\circ} \mathrm{C}$ and at a specific gravity of approximately 1 .

26. Attach the sample basket to the bottom of the scale as shown in the diagram below. Make sure to tare the scale prior to starting testing and allow the scale to come to a complete rest before taking the measurement.

27. Place the sample into the basket and record the weight as the suspended weight (S Sax).

28. Calculate the volume $(\mathrm{V})$ as the difference between the original dry weight, $\mathrm{W}$, and the suspended weight, $S_{\text {Wax. }}$.

29. Calculate the bulk density by dividing the dry weight, W, by the volume ,V. 
Data:

Rock 1: Granite

\begin{tabular}{|c|c|c|c|c|}
\hline $\begin{array}{c}\text { Sample } \\
\text { ID }\end{array}$ & $\begin{array}{c}\text { Dry Weight } \\
(\mathrm{g})\end{array}$ & $\begin{array}{c}\text { Shrink Wrap } \\
\text { Coated Weight } \\
(\mathrm{g})\end{array}$ & $\begin{array}{c}\text { Shrink Wrap and } \\
\text { Wax Coated Weight } \\
(\mathrm{g})\end{array}$ & $\begin{array}{c}\text { Suspended } \\
\text { Weight } \\
(\mathrm{g})\end{array}$ \\
\hline $1-1-1$ & 704.07 & 706.62 & 717.14 & 430.90 \\
\hline $1-1-2$ & 466.39 & 468.93 & 474.18 & 283.98 \\
\hline $1-1-4$ & 444.14 & 446.38 & 452.99 & 269.05 \\
\hline
\end{tabular}

\begin{tabular}{|c|c|c|c|c|c|}
\hline $\begin{array}{c}\text { Sample } \\
\text { ID }\end{array}$ & $\begin{array}{c}\text { Weight of } \\
\text { Shrink Wrap } \\
(\mathrm{g})\end{array}$ & $\begin{array}{c}\text { Weight of } \\
\text { Wax } \\
(\mathrm{g})\end{array}$ & $\begin{array}{c}\text { Volume of } \\
\text { Shrink } \\
\text { Wrap } \\
\left(\mathrm{cm}^{\wedge} 3\right)\end{array}$ & $\begin{array}{c}\text { Volume } \\
\text { of Wax } \\
\left(\mathrm{cm}^{\wedge} 3\right)\end{array}$ & $\begin{array}{c}\text { Total Volume } \\
\text { Suspended } \\
\left(\mathrm{cm}^{\wedge} 3\right)\end{array}$ \\
\hline $1-1-1$ & 2.55 & 10.52 & 2.32 & 11.70 & 286.24 \\
\hline $1-1-2$ & 2.54 & 5.25 & 2.31 & 5.84 & 190.20 \\
\hline $1-1-4$ & 2.24 & 6.61 & 2.04 & 7.35 & 183.94 \\
\hline
\end{tabular}

\begin{tabular}{|c|c|c|}
\hline $\begin{array}{c}\text { Sample } \\
\text { ID }\end{array}$ & $\begin{array}{c}\text { Volume of } \\
\text { Sample } \\
\left(\mathrm{cm}^{\wedge} 3\right)\end{array}$ & $\begin{array}{c}\text { Density of } \\
\text { Sample } \\
\left(\mathrm{g} / \mathrm{cm}^{\wedge} 3\right)\end{array}$ \\
\hline $1-1-1$ & 272.22 & 2.59 \\
\hline $1-1-2$ & 182.05 & 2.56 \\
\hline $1-1-4$ & 174.55 & 2.54 \\
\hline
\end{tabular}

Rock 2: Kona Dolomite

\begin{tabular}{|c|c|c|c|c|}
\hline $\begin{array}{c}\text { Sample } \\
\text { ID }\end{array}$ & $\begin{array}{c}\text { Dry Weight } \\
(\mathrm{g})\end{array}$ & $\begin{array}{c}\text { Shrink Wrap } \\
\text { Coated Weight } \\
(\mathrm{g})\end{array}$ & $\begin{array}{c}\text { Shrink Wrap and } \\
\text { Wax Coated Weight } \\
(\mathrm{g})\end{array}$ & $\begin{array}{c}\text { Suspended } \\
\text { Weight } \\
(\mathrm{g})\end{array}$ \\
\hline $2-1-1$ & 508.52 & 510.83 & 517.30 & 314.74 \\
\hline $2-1-2$ & 491.05 & 493.20 & 499.96 & 305.38 \\
\hline $2-1-3$ & 510.86 & 513.23 & 519.15 & 319.48 \\
\hline $2-1-4$ & 511.92 & 514.91 & 522.37 & 316.58 \\
\hline $2-2-1$ & 536.08 & 538.78 & 547.27 & 344.73 \\
\hline $2-2-2$ & 518.29 & 520.75 & 526.75 & 326.05 \\
\hline $2-2-3$ & 532.30 & 534.50 & 538.95 & 339.00 \\
\hline $2-2-4$ & 502.92 & 505.05 & 510.40 & 321.90 \\
\hline $2-2-5$ & 502.02 & 504.66 & 510.57 & 321.93 \\
\hline $2-2-6$ & 505.37 & 507.48 & 512.93 & 310.74 \\
\hline
\end{tabular}




\begin{tabular}{|c|c|c|c|c|c|}
\hline $\begin{array}{c}\text { Sample } \\
\text { ID }\end{array}$ & $\begin{array}{c}\text { Weight of } \\
\text { Shrink Wrap } \\
(\mathrm{g})\end{array}$ & $\begin{array}{c}\text { Weight of } \\
\text { Wax } \\
(\mathrm{g})\end{array}$ & $\begin{array}{c}\text { Volume of } \\
\text { Shrink } \\
\text { Wrap } \\
\left(\mathrm{cm}^{\wedge} 3\right)\end{array}$ & $\begin{array}{c}\text { Volume of } \\
\text { Wax } \\
\left(\mathrm{cm}^{\wedge} 3\right)\end{array}$ & $\begin{array}{c}\text { Total } \\
\text { Volume } \\
\text { Suspended } \\
\left(\mathrm{cm}^{\wedge} 3\right)\end{array}$ \\
\hline $2-1-1$ & 2.31 & 6.47 & 2.10 & 7.19 & 202.56 \\
\hline $2-1-2$ & 2.15 & 6.76 & 1.96 & 7.52 & 194.58 \\
\hline $2-1-3$ & 2.37 & 5.92 & 2.16 & 6.58 & 199.67 \\
\hline $2-1-4$ & 2.99 & 7.46 & 2.72 & 8.29 & 205.79 \\
\hline $2-2-1$ & 2.70 & 8.49 & 2.46 & 9.44 & 202.54 \\
\hline $2-2-2$ & 2.46 & 6.00 & 2.24 & 6.67 & 200.70 \\
\hline $2-2-3$ & 2.20 & 4.45 & 2.00 & 4.95 & 199.95 \\
\hline $2-2-4$ & 2.13 & 5.35 & 1.94 & 5.95 & 188.50 \\
\hline $2-2-5$ & 2.64 & 5.91 & 2.41 & 6.57 & 188.64 \\
\hline $2-2-6$ & 2.11 & 5.45 & 1.92 & 6.06 & 202.19 \\
\hline
\end{tabular}

\begin{tabular}{|c|c|c|}
\hline $\begin{array}{c}\text { Sample } \\
\text { ID }\end{array}$ & $\begin{array}{c}\text { Volume of } \\
\text { Sample } \\
\left(\mathrm{cm}^{\wedge} 3\right)\end{array}$ & $\begin{array}{c}\text { Density of } \\
\text { Sample } \\
\left(\mathrm{g} / \mathrm{cm}^{\wedge} 3\right)\end{array}$ \\
\hline $2-1-1$ & 193.26 & 2.63 \\
\hline $2-1-2$ & 185.11 & 2.65 \\
\hline $2-1-3$ & 190.93 & 2.68 \\
\hline $2-1-4$ & 194.77 & 2.63 \\
\hline $2-2-1$ & 190.64 & 2.81 \\
\hline $2-2-2$ & 191.79 & 2.70 \\
\hline $2-2-3$ & 193.00 & 2.76 \\
\hline $2-2-4$ & 180.61 & 2.78 \\
\hline $2-2-5$ & 179.66 & 2.79 \\
\hline $2-2-6$ & 194.21 & 2.60 \\
\hline
\end{tabular}

Rock 3: Pelkie Dolomite

\begin{tabular}{|c|c|c|c|c|}
\hline $\begin{array}{c}\text { Sample } \\
\text { ID }\end{array}$ & $\begin{array}{c}\text { Dry Weight } \\
(\mathrm{g})\end{array}$ & $\begin{array}{c}\text { Shrink Wrap } \\
\text { Coated Weight } \\
(\mathrm{g})\end{array}$ & $\begin{array}{c}\text { Shrink Wrap and } \\
\text { Wax Coated Weight } \\
(\mathrm{g})\end{array}$ & $\begin{array}{c}\text { Suspended } \\
\text { Weight } \\
(\mathrm{g})\end{array}$ \\
\hline $3-2-1$ & 257.67 & 259.95 & 264.97 & 152.56 \\
\hline $3-3-1$ & 338.88 & 341.24 & 346.61 & 208.67 \\
\hline
\end{tabular}




\begin{tabular}{|c|c|c|c|c|c|}
\hline $\begin{array}{c}\text { Sample } \\
\text { ID }\end{array}$ & $\begin{array}{c}\text { Weight of } \\
\text { Shrink Wrap } \\
(\mathrm{g})\end{array}$ & $\begin{array}{c}\text { Weight of } \\
\text { Wax } \\
(\mathrm{g})\end{array}$ & $\begin{array}{c}\text { Volume of } \\
\text { Shrink } \\
\text { Wrap } \\
\left(\mathrm{cm}^{\wedge} 3\right)\end{array}$ & $\begin{array}{c}\text { Volume of } \\
\text { Wax } \\
\left(\mathrm{cm}^{\wedge} 3\right)\end{array}$ & $\begin{array}{c}\text { Total } \\
\text { Volume } \\
\text { Suspended } \\
\left(\mathrm{cm}^{\wedge} 3\right)\end{array}$ \\
\hline $3-2-1$ & 2.28 & 5.02 & 2.08 & 5.58 & 112.41 \\
\hline $3-3-1$ & 2.36 & 5.37 & 2.15 & 5.97 & 137.94 \\
\hline
\end{tabular}

\begin{tabular}{|c|c|c|}
\hline $\begin{array}{c}\text { Sample } \\
\text { ID }\end{array}$ & $\begin{array}{c}\text { Volume of } \\
\text { Sample } \\
\left(\mathrm{cm}^{\wedge} 3\right)\end{array}$ & $\begin{array}{c}\text { Density of } \\
\text { Sample } \\
\left(\mathrm{g} / \mathrm{cm}^{\wedge} 3\right)\end{array}$ \\
\hline $3-2-1$ & 104.75 & 2.46 \\
\hline $3-3-1$ & 129.82 & 2.61 \\
\hline
\end{tabular}

Rock 4: Various Carbonates

\begin{tabular}{|c|c|c|c|c|}
\hline $\begin{array}{c}\text { Sample } \\
\text { ID }\end{array}$ & $\begin{array}{c}\text { Dry Weight } \\
(\mathrm{g})\end{array}$ & $\begin{array}{c}\text { Shrink Wrap } \\
\text { Coated Weight } \\
(\mathrm{g})\end{array}$ & $\begin{array}{c}\text { Shrink Wrap and } \\
\text { Wax Coated Weight } \\
(\mathrm{g})\end{array}$ & $\begin{array}{c}\text { Suspended } \\
\text { Weight } \\
(\mathrm{g})\end{array}$ \\
\hline $4-1-1$ & 456.25 & 458.62 & 464.94 & 283.16 \\
\hline $4-1-2$ & 491.54 & 493.97 & 499.44 & 307.02 \\
\hline $4-1-3$ & 646.71 & 649.41 & 656.61 & 404.06 \\
\hline $4-1-4$ & 794.69 & 796.65 & 811.42 & 500.28 \\
\hline $4-1-5$ & 469.04 & 471.18 & 476.12 & 293.71 \\
\hline $4-2-1$ & 448.33 & 450.46 & 456.35 & 275.30 \\
\hline $4-2-2$ & 454.36 & 456.32 & 462.79 & 277.99 \\
\hline $4-2-3$ & 478.36 & 480.39 & 484.94 & 292.85 \\
\hline $4-3-1$ & 196.07 & 197.71 & 201.33 & 119.91 \\
\hline $4-3-2$ & 361.80 & 363.86 & 368.84 & 224.14 \\
\hline $4-3-3$ & 331.60 & 334.06 & 338.03 & 204.81 \\
\hline $4-4-1$ & 343.90 & 345.96 & 351.06 & 208.96 \\
\hline $4-4-2$ & 412.30 & 414.26 & 421.61 & 248.40 \\
\hline $4-4-3$ & 381.18 & 383.81 & 389.52 & 232.83 \\
\hline $4-5-1$ & 594.52 & 596.96 & 606.31 & 366.38 \\
\hline
\end{tabular}




\begin{tabular}{|c|c|c|c|c|c|}
\hline $\begin{array}{c}\text { Sample } \\
\text { ID }\end{array}$ & $\begin{array}{c}\text { Weight of } \\
\text { Shrink Wrap } \\
(\mathrm{g})\end{array}$ & $\begin{array}{c}\text { Weight of } \\
\text { Wax } \\
(\mathrm{g})\end{array}$ & $\begin{array}{c}\text { Volume of } \\
\text { Shrink } \\
\text { Wrap } \\
\left(\mathrm{cm}^{\wedge} 3\right)\end{array}$ & $\begin{array}{c}\text { Volume of } \\
\text { Wax } \\
\left(\mathrm{cm}^{\wedge} 3\right)\end{array}$ & $\begin{array}{c}\text { Total } \\
\text { Volume } \\
\text { Suspended } \\
\left(\mathrm{cm}^{\wedge} 3\right)\end{array}$ \\
\hline $4-1-1$ & 2.37 & 6.32 & 2.16 & 7.03 & 181.78 \\
\hline $4-1-2$ & 2.43 & 5.47 & 2.21 & 6.08 & 192.42 \\
\hline $4-1-3$ & 2.70 & 7.20 & 2.46 & 8.01 & 252.55 \\
\hline $4-1-4$ & 1.96 & 14.77 & 1.79 & 16.42 & 311.14 \\
\hline $4-1-5$ & 2.14 & 4.94 & 1.95 & 5.49 & 182.41 \\
\hline $4-2-1$ & 2.13 & 5.89 & 1.94 & 6.55 & 181.05 \\
\hline $4-2-2$ & 1.96 & 6.47 & 1.79 & 7.19 & 184.80 \\
\hline $4-2-3$ & 2.03 & 4.55 & 1.85 & 5.06 & 192.09 \\
\hline $4-3-1$ & 1.64 & 3.62 & 1.49 & 4.02 & 81.42 \\
\hline $4-3-2$ & 2.06 & 4.98 & 1.88 & 5.54 & 144.70 \\
\hline $4-3-3$ & 2.46 & 3.97 & 2.24 & 4.41 & 133.22 \\
\hline $4-4-1$ & 2.06 & 5.10 & 1.88 & 5.67 & 142.10 \\
\hline $4-4-2$ & 1.96 & 7.35 & 1.79 & 8.17 & 173.21 \\
\hline $4-4-3$ & 2.63 & 5.71 & 2.40 & 6.35 & 156.69 \\
\hline $4-5-1$ & 2.44 & 9.35 & 2.22 & 10.40 & 239.93 \\
\hline
\end{tabular}

\begin{tabular}{|c|c|c|}
\hline $\begin{array}{c}\text { Sample } \\
\text { ID }\end{array}$ & $\begin{array}{c}\text { Volume of } \\
\text { Sample } \\
\left(\mathrm{cm}^{\wedge} 3\right)\end{array}$ & $\begin{array}{c}\text { Density of } \\
\text { Sample } \\
\left(\mathrm{g} / \mathrm{cm}^{\wedge} 3\right)\end{array}$ \\
\hline $4-1-1$ & 172.59 & 2.64 \\
\hline $4-1-2$ & 184.12 & 2.67 \\
\hline $4-1-3$ & 242.08 & 2.67 \\
\hline $4-1-4$ & 292.93 & 2.71 \\
\hline $4-1-5$ & 174.97 & 2.68 \\
\hline $4-2-1$ & 172.56 & 2.60 \\
\hline $4-2-2$ & 175.82 & 2.58 \\
\hline $4-2-3$ & 185.18 & 2.58 \\
\hline $4-3-1$ & 75.90 & 2.58 \\
\hline $4-3-2$ & 137.29 & 2.64 \\
\hline $4-3-3$ & 126.56 & 2.62 \\
\hline $4-4-1$ & 134.55 & 2.56 \\
\hline $4-4-2$ & 163.25 & 2.53 \\
\hline $4-4-3$ & 147.95 & 2.58 \\
\hline $4-5-1$ & 227.31 & 2.62 \\
\hline
\end{tabular}


Rock 5: Levi Blast Slag

\begin{tabular}{|c|c|c|c|c|}
\hline $\begin{array}{c}\text { Sample } \\
\text { ID }\end{array}$ & $\begin{array}{c}\text { Dry Weight } \\
(\mathrm{g})\end{array}$ & $\begin{array}{c}\text { Shrink Wrap } \\
\text { Coated Weight } \\
(\mathrm{g})\end{array}$ & $\begin{array}{c}\text { Shrink Wrap and } \\
\text { Wax Coated Weight } \\
(\mathrm{g})\end{array}$ & $\begin{array}{c}\text { Suspended } \\
\text { Weight } \\
(\mathrm{g})\end{array}$ \\
\hline $5-1-1$ & 419.31 & 421.69 & 427.50 & 229.67 \\
\hline $5-1-2$ & 395.36 & 397.59 & 405.18 & 220.34 \\
\hline $5-1-3$ & 433.40 & 435.26 & 441.67 & 240.76 \\
\hline $5-1-4$ & 425.72 & 427.95 & 432.91 & 238.55 \\
\hline $5-1-5$ & 341.78 & 343.82 & 359.16 & 188.24 \\
\hline $5-2-1$ & 366.55 & 368.68 & 374.75 & 179.05 \\
\hline $5-2-2$ & 451.25 & 453.97 & 460.96 & 264.92 \\
\hline $5-2-3$ & 507.92 & 510.48 & 521.17 & 290.29 \\
\hline $5-2-5$ & 320.64 & 322.68 & 329.72 & 150.52 \\
\hline $5-3-1$ & 390.43 & 392.55 & 399.03 & 209.21 \\
\hline $5-3-2$ & 366.66 & 368.27 & 375.93 & 182.84 \\
\hline $5-3-3$ & 349.80 & 352.73 & 359.63 & 166.52 \\
\hline
\end{tabular}

\begin{tabular}{|c|c|c|c|c|c|}
\hline $\begin{array}{c}\text { Sample } \\
\text { ID }\end{array}$ & $\begin{array}{c}\text { Weight of } \\
\text { Shrink Wrap } \\
(\mathrm{g})\end{array}$ & $\begin{array}{c}\text { Weight of } \\
\text { Wax } \\
(\mathrm{g})\end{array}$ & $\begin{array}{c}\text { Volume of } \\
\text { Shrink } \\
\text { Wrap } \\
\left(\mathrm{cm}^{\wedge} 3\right)\end{array}$ & $\begin{array}{c}\text { Volume of } \\
\text { Wax } \\
\left(\mathrm{cm}^{\wedge} 3\right)\end{array}$ & $\begin{array}{c}\text { Total } \\
\text { Volume } \\
\text { Suspended } \\
\left(\mathrm{cm}^{\wedge} 3\right)\end{array}$ \\
\hline $5-1-1$ & 2.38 & 5.81 & 2.17 & 6.46 & 197.83 \\
\hline $5-1-2$ & 2.23 & 7.59 & 2.03 & 8.44 & 184.84 \\
\hline $5-1-3$ & 1.86 & 6.41 & 1.69 & 7.13 & 200.91 \\
\hline $5-1-4$ & 2.23 & 4.96 & 2.03 & 5.51 & 194.36 \\
\hline $5-1-5$ & 2.04 & 15.34 & 1.86 & 17.06 & 170.92 \\
\hline $5-2-1$ & 2.13 & 6.07 & 1.94 & 6.75 & 195.70 \\
\hline $5-2-2$ & 2.72 & 6.99 & 2.48 & 7.77 & 196.04 \\
\hline $5-2-3$ & 2.56 & 10.69 & 2.33 & 11.89 & 230.88 \\
\hline $5-2-5$ & 2.04 & 7.04 & 1.86 & 7.83 & 179.20 \\
\hline $5-3-1$ & 2.12 & 6.48 & 1.93 & 7.20 & 189.82 \\
\hline $5-3-2$ & 1.61 & 7.66 & 1.47 & 8.52 & 193.09 \\
\hline $5-3-3$ & 2.93 & 6.90 & 2.67 & 7.67 & 193.11 \\
\hline
\end{tabular}




\begin{tabular}{|c|c|c|}
\hline $\begin{array}{c}\text { Sample } \\
\text { ID }\end{array}$ & $\begin{array}{c}\text { Volume of } \\
\text { Sample } \\
\left(\mathrm{cm}^{\wedge} 3\right)\end{array}$ & $\begin{array}{c}\text { Density of } \\
\text { Sample } \\
\left(\mathrm{g} / \mathrm{cm}^{\wedge} 3\right)\end{array}$ \\
\hline $5-1-1$ & 189.20 & 2.22 \\
\hline $5-1-2$ & 174.37 & 2.27 \\
\hline $5-1-3$ & 192.09 & 2.26 \\
\hline $5-1-4$ & 186.81 & 2.28 \\
\hline $5-1-5$ & 152.01 & 2.25 \\
\hline $5-2-1$ & 187.01 & 1.96 \\
\hline $5-2-2$ & 185.79 & 2.43 \\
\hline $5-2-3$ & 216.66 & 2.34 \\
\hline $5-2-5$ & 169.51 & 1.89 \\
\hline $5-3-1$ & 180.68 & 2.16 \\
\hline $5-3-2$ & 183.11 & 2.00 \\
\hline $5-3-3$ & 182.77 & 1.91 \\
\hline
\end{tabular}

Rock 6: Jacobsville Sandstone

\begin{tabular}{|c|c|c|c|c|}
\hline $\begin{array}{c}\text { Sample } \\
\text { ID }\end{array}$ & $\begin{array}{c}\text { Dry Weight } \\
(\mathrm{g})\end{array}$ & $\begin{array}{c}\text { Shrink Wrap } \\
\text { Coated Weight } \\
(\mathrm{g})\end{array}$ & $\begin{array}{c}\text { Shrink Wrap and Wax } \\
\text { Coated Weight } \\
(\mathrm{g})\end{array}$ & $\begin{array}{c}\text { Suspended } \\
\text { Weight } \\
(\mathrm{g})\end{array}$ \\
\hline $6-1-1$ & 383.54 & 381.69 & 389.35 & 196.70 \\
\hline $6-1-2$ & 375.43 & 377.77 & 383.69 & 195.96 \\
\hline $6-1-3$ & 372.87 & 375.47 & 382.23 & 188.62 \\
\hline $6-1-4$ & 377.20 & 379.54 & 385.01 & 196.06 \\
\hline $6-1-5$ & 383.19 & 385.52 & 392.34 & 196.89 \\
\hline $6-1-6$ & 372.07 & 374.19 & 380.46 & 193.17 \\
\hline $6-1-7$ & 387.97 & 390.10 & 396.68 & 198.25 \\
\hline $6-1-8$ & 379.24 & 381.57 & 386.29 & 194.98 \\
\hline $6-1-9$ & 380.48 & 382.92 & 389.15 & 193.54 \\
\hline $6-1-10$ & 377.69 & 379.81 & 386.47 & 194.89 \\
\hline $6-1-11$ & 383.53 & 385.51 & 391.39 & 197.82 \\
\hline $6-1-12$ & 377.75 & 379.80 & 387.20 & 196.28 \\
\hline
\end{tabular}




\begin{tabular}{|c|c|c|c|c|c|}
\hline $\begin{array}{c}\text { Sample } \\
\text { ID }\end{array}$ & $\begin{array}{c}\text { Weight of } \\
\text { Shrink Wrap } \\
(\mathrm{g})\end{array}$ & $\begin{array}{c}\text { Weight of } \\
\text { Wax } \\
(\mathrm{g})\end{array}$ & $\begin{array}{c}\text { Volume of } \\
\text { Shrink } \\
\text { Wrap } \\
\left(\mathrm{cm}^{\wedge} 3\right)\end{array}$ & $\begin{array}{c}\text { Volume of } \\
\text { Wax } \\
\left(\mathrm{cm}^{\wedge} 3\right)\end{array}$ & $\begin{array}{c}\text { Total } \\
\text { Volume } \\
\text { Suspended } \\
\left(\mathrm{cm}^{\wedge} 3\right)\end{array}$ \\
\hline $6-1-1$ & -1.85 & 7.66 & -1.69 & 8.52 & 192.65 \\
\hline $6-1-2$ & 2.34 & 5.92 & 2.13 & 6.58 & 187.73 \\
\hline $6-1-3$ & 2.60 & 6.76 & 2.37 & 7.52 & 193.61 \\
\hline $6-1-4$ & 2.34 & 5.47 & 2.13 & 6.08 & 188.95 \\
\hline $6-1-5$ & 2.33 & 6.82 & 2.12 & 7.58 & 195.45 \\
\hline $6-1-6$ & 2.12 & 6.27 & 1.93 & 6.97 & 187.29 \\
\hline $6-1-7$ & 2.13 & 6.58 & 1.94 & 7.32 & 198.43 \\
\hline $6-1-8$ & 2.33 & 4.72 & 2.12 & 5.25 & 191.31 \\
\hline $6-1-9$ & 2.44 & 6.23 & 2.22 & 6.93 & 195.61 \\
\hline $6-1-10$ & 2.12 & 6.66 & 1.93 & 7.40 & 191.58 \\
\hline $6-1-11$ & 1.98 & 5.88 & 1.80 & 6.54 & 193.57 \\
\hline $6-1-12$ & 2.05 & 7.40 & 1.87 & 8.23 & 190.92 \\
\hline
\end{tabular}

\begin{tabular}{|c|c|r|}
\hline $\begin{array}{c}\text { Sample } \\
\text { ID }\end{array}$ & $\begin{array}{c}\text { Volume of } \\
\text { Sample } \\
\left(\mathrm{cm}^{\wedge} 3\right)\end{array}$ & $\begin{array}{c}\text { Density of } \\
\text { Sample } \\
\left(\mathrm{g} / \mathrm{cm}^{\wedge} 3\right)\end{array}$ \\
\hline $6-1-1$ & 185.82 & 2.06 \\
\hline $6-1-2$ & 179.02 & 2.10 \\
\hline $6-1-3$ & 183.73 & 2.03 \\
\hline $6-1-4$ & 180.74 & 2.09 \\
\hline $6-1-5$ & 185.74 & 2.06 \\
\hline $6-1-6$ & 178.39 & 2.09 \\
\hline $6-1-7$ & 189.17 & 2.05 \\
\hline $6-1-8$ & 183.94 & 2.06 \\
\hline $6-1-9$ & 186.46 & 2.04 \\
\hline $6-1-10$ & 182.24 & 2.07 \\
\hline $6-1-11$ & 185.23 & 2.07 \\
\hline $6-1-12$ & 180.82 & 2.09 \\
\hline
\end{tabular}


Rock 7: Algoma Blast Slag

\begin{tabular}{|c|c|c|c|c|}
\hline $\begin{array}{c}\text { Sample } \\
\text { ID }\end{array}$ & $\begin{array}{c}\text { Dry Weight } \\
(\mathrm{g})\end{array}$ & $\begin{array}{c}\text { Shrink Wrap } \\
\text { Coated Weight } \\
(\mathrm{g})\end{array}$ & $\begin{array}{c}\text { Shrink Wrap and Wax } \\
\text { Coated Weight } \\
(\mathrm{g})\end{array}$ & $\begin{array}{c}\text { Suspended } \\
\text { Weight } \\
(\mathrm{g})\end{array}$ \\
\hline $7-1$ & 384.24 & 385.88 & 393.94 & 199.38 \\
\hline $7-2$ & 349.24 & 351.33 & 357.56 & 183.94 \\
\hline $7-3$ & 344.64 & 346.73 & 352.76 & 173.77 \\
\hline $7-4$ & 320.56 & 323.08 & 329.26 & 137.23 \\
\hline $7-5$ & 384.52 & 386.53 & 391.28 & 205.77 \\
\hline $7-6$ & 380.54 & 382.64 & 388.69 & 198.58 \\
\hline $7-7$ & 480.27 & 482.24 & 489.22 & 233.31 \\
\hline $7-8$ & 354.17 & 356.35 & 361.82 & 187.74 \\
\hline
\end{tabular}

\begin{tabular}{|c|c|c|c|c|c|}
\hline $\begin{array}{c}\text { Sample } \\
\text { ID }\end{array}$ & $\begin{array}{c}\text { Weight of } \\
\text { Shrink Wrap } \\
(\mathrm{g})\end{array}$ & $\begin{array}{c}\text { Weight of } \\
\text { Wax } \\
(\mathrm{g})\end{array}$ & $\begin{array}{c}\text { Volume of } \\
\text { Shrink } \\
\text { Wrap } \\
\left(\mathrm{cm}^{\wedge} 3\right)\end{array}$ & $\begin{array}{c}\text { Volume of } \\
\text { Wax } \\
\left(\mathrm{cm}^{\wedge} 3\right)\end{array}$ & $\begin{array}{c}\text { Total } \\
\text { Volume } \\
\text { Suspended } \\
\left(\mathrm{cm}^{\wedge} 3\right)\end{array}$ \\
\hline $7-1$ & 1.64 & 8.06 & 1.49 & 8.96 & 194.56 \\
\hline $7-2$ & 2.09 & 6.23 & 1.90 & 6.93 & 173.62 \\
\hline $7-3$ & 2.09 & 6.03 & 1.90 & 6.70 & 178.99 \\
\hline $7-4$ & 2.52 & 6.18 & 2.30 & 6.87 & 192.03 \\
\hline $7-5$ & 2.01 & 4.75 & 1.83 & 5.28 & 185.51 \\
\hline $7-6$ & 2.10 & 6.05 & 1.91 & 6.73 & 190.11 \\
\hline $7-7$ & 1.97 & 6.98 & 1.79 & 7.76 & 255.91 \\
\hline $7-8$ & 2.18 & 5.47 & 1.99 & 6.08 & 174.08 \\
\hline
\end{tabular}

\begin{tabular}{|c|c|c|}
\hline $\begin{array}{c}\text { Sample } \\
\text { ID }\end{array}$ & $\begin{array}{c}\text { Volume of } \\
\text { Sample } \\
\left(\mathrm{cm}^{\wedge} 3\right)\end{array}$ & $\begin{array}{c}\text { Density of } \\
\text { Sample } \\
\left(\mathrm{g} / \mathrm{cm}^{\wedge} 3\right)\end{array}$ \\
\hline $7-1$ & 184.10 & 2.09 \\
\hline $7-2$ & 164.79 & 2.12 \\
\hline $7-3$ & 170.38 & 2.02 \\
\hline $7-4$ & 182.86 & 1.75 \\
\hline $7-5$ & 178.40 & 2.16 \\
\hline $7-6$ & 181.47 & 2.10 \\
\hline $7-7$ & 246.35 & 1.95 \\
\hline $7-8$ & 166.01 & 2.13 \\
\hline
\end{tabular}




\begin{tabular}{|c|c|c|c|c|c|c|}
\hline $\begin{array}{c}\text { Sample } \\
\#\end{array}$ & $\begin{array}{c}\text { Dry Weight } \\
(\mathrm{g})\end{array}$ & $\begin{array}{c}\text { Shrink } \\
\text { Wrap } \\
\text { Coated } \\
\text { Weight }(\mathrm{g})\end{array}$ & $\begin{array}{c}\text { Shrink Wrap } \\
\text { and Wax } \\
\text { Coated } \\
\text { Weight }(\mathrm{g})\end{array}$ & $\begin{array}{c}\text { Suspende } \\
\text { d Weight } \\
(\mathrm{g})\end{array}$ & $\begin{array}{c}\text { Weight of } \\
\text { Shrink } \\
\text { Wrap (g) }\end{array}$ & $\begin{array}{c}\text { Weight of } \\
\text { Wax } \\
(\mathrm{g})\end{array}$ \\
\hline $1-1-1$ & 704.08 & 706.46 & 717.39 & 432.40 & 2.38 & 10.93 \\
\hline $2-1-2$ & 491.03 & 493.45 & 500.86 & 303.24 & 2.42 & 7.41 \\
\hline $2-2-6$ & 505.36 & 507.96 & 513.83 & 311.30 & 2.60 & 5.87 \\
\hline $3-2-1$ & 257.69 & 259.90 & 263.61 & 156.65 & 2.21 & 3.71 \\
\hline $4-1-5$ & 469.04 & 471.23 & 477.75 & 293.56 & 2.19 & 6.52 \\
\hline $4-3-1$ & 196.07 & 197.60 & 200.54 & 119.88 & 1.53 & 2.94 \\
\hline $4-4-3$ & 381.20 & 383.66 & 390.82 & 233.15 & 2.46 & 7.16 \\
\hline $5-1-4$ & 425.73 & 427.92 & 433.67 & 238.12 & 2.19 & 5.75 \\
\hline $5-2-5$ & 320.62 & 322.80 & 329.97 & 153.95 & 2.18 & 7.17 \\
\hline $5-3-1$ & 390.44 & 392.09 & 398.08 & 211.94 & 1.65 & 5.99 \\
\hline $5-1-1$ & 419.30 & 421.64 & 428.96 & 233.40 & 2.34 & 7.32 \\
\hline $5-3-3$ & 349.83 & 352.14 & 358.27 & 168.20 & 2.31 & 6.13 \\
\hline $6-1-3$ & 372.91 & 375.16 & 382.04 & 193.25 & 2.25 & 6.88 \\
\hline $6-1-10$ & 377.67 & 379.74 & 386.27 & 195.19 & 2.07 & 6.53 \\
\hline $7-1$ & 384.17 & 386.47 & 392.12 & 198.94 & 2.30 & 5.65 \\
\hline $7-2$ & 349.16 & 351.41 & 357.36 & 185.16 & 2.25 & 5.95 \\
\hline
\end{tabular}




\begin{tabular}{|c|c|c|c|c|c|}
\hline $\begin{array}{c}\text { Sample } \\
\#\end{array}$ & $\begin{array}{c}\text { Volume of } \\
\text { Shrink Wrap } \\
\left(\mathrm{cm}^{\wedge} 3\right)\end{array}$ & $\begin{array}{c}\text { Volume } \\
\text { of Wax } \\
\left(\mathrm{cm}^{\wedge} 3\right)\end{array}$ & $\begin{array}{c}\text { Total } \\
\text { Volume } \\
\text { Suspended } \\
\left(\mathrm{cm}^{\wedge} 3\right)\end{array}$ & $\begin{array}{c}\text { Volume of } \\
\text { Sample } \\
\left(\mathrm{cm}^{\wedge} 3\right)\end{array}$ & $\begin{array}{c}\text { Density of } \\
\text { Sample } \\
\left(\mathrm{g} / \mathrm{cm}^{\wedge} 3\right)\end{array}$ \\
\hline $1-1-1$ & 2.17 & 12.15 & 284.99 & 270.67 & 2.60 \\
\hline $2-1-2$ & 2.20 & 8.24 & 197.62 & 187.18 & 2.62 \\
\hline $2-2-6$ & 2.37 & 6.53 & 202.53 & 193.63 & 2.61 \\
\hline $3-2-1$ & 2.01 & 4.12 & 106.96 & 100.82 & 2.56 \\
\hline $4-1-5$ & 2.00 & 7.25 & 184.19 & 174.95 & 2.68 \\
\hline $4-3-1$ & 1.39 & 3.27 & 80.66 & 76.00 & 2.58 \\
\hline $4-4-3$ & 2.24 & 7.96 & 157.67 & 147.47 & 2.58 \\
\hline $5-1-4$ & 2.00 & 6.39 & 195.55 & 187.16 & 2.27 \\
\hline $5-2-5$ & 1.99 & 7.97 & 176.02 & 166.06 & 1.93 \\
\hline $5-3-1$ & 1.50 & 6.66 & 186.14 & 177.98 & 2.19 \\
\hline $5-1-1$ & 2.13 & 8.14 & 195.56 & 185.29 & 2.26 \\
\hline $5-3-3$ & 2.10 & 6.82 & 190.07 & 181.15 & 1.93 \\
\hline $6-1-3$ & 2.05 & 7.65 & 188.79 & 179.09 & 2.08 \\
\hline $6-1-10$ & 1.89 & 7.26 & 191.08 & 181.93 & 2.08 \\
\hline $7-1$ & 2.10 & 6.28 & 193.18 & 184.80 & 2.08 \\
\hline $7-2$ & 2.05 & 6.62 & 172.20 & 163.53 & 2.14 \\
\hline
\end{tabular}

\begin{tabular}{|c|c|c|c|}
\hline $\begin{array}{c}\text { Sample } \# \\
1-1-1\end{array}$ & $\begin{array}{c}\text { Original Bulk } \\
\text { Density } \\
\left(\mathrm{g} / \mathrm{cm}^{\wedge}\right)\end{array}$ & $\begin{array}{c}\text { QA/QC Density of } \\
\text { Sample } \\
\left(\mathrm{g} / \mathrm{cm}^{\wedge} 3\right)\end{array}$ & $\begin{array}{c}\text { Percent Difference } \\
\text { Between Original Data } \\
\text { and QA/QC Samples }\end{array}$ \\
\hline $2-1-2$ & 2.59 & 2.60 & -0.43 \\
\hline $2-2-6$ & 2.65 & 2.62 & 1.01 \\
\hline $3-2-1$ & 2.6 & 2.61 & -0.38 \\
\hline $4-1-5$ & 2.46 & 2.56 & -3.82 \\
\hline $4-3-1$ & 2.68 & 2.68 & -0.04 \\
\hline $4-4-3$ & 2.58 & 2.58 & 0.00 \\
\hline $5-1-4$ & 2.58 & 2.58 & -0.19 \\
\hline $5-2-5$ & 2.28 & 2.27 & 0.23 \\
\hline $5-3-1$ & 1.89 & 1.93 & -2.13 \\
\hline $5-1-1$ & 2.16 & 2.19 & -1.55 \\
\hline $5-3-3$ & 2.22 & 2.26 & -1.92 \\
\hline $6-1-3$ & 1.91 & 1.93 & -1.10 \\
\hline $6-1-10$ & 2.03 & 2.08 & -2.54 \\
\hline $7-1$ & 2.07 & 2.08 & -0.28 \\
\hline $7-2$ & 2.09 & 2.08 & 0.54 \\
\hline
\end{tabular}




\section{Appendix F: Saturated Surface Dry (SSD) Results and Procedures}

A popular method of testing in the aggregate industry is the Saturated Surface Dry (SSD method) as outlined in ASTM C 127-07. This method determines a relative density or specific gravity of a material (ASTM, 2009). This ASTM actually introduces several different methods for calculating the specific gravity of a material that differ based on how the void space in the samples are handled (S. J. Vitton, Lehman, M.A., Van Dam, T.J., 1998).

A flaw in the SSD method is that not all of the interior voids of the sample will be filled with water and the logic behind this method assumes that 24 hours, is in fact, long enough to reach one hundred percent saturation. In order to test this theory, some samples of each material were saturated for a 24 hour period in order to see at which point the sample eventually reached $100 \%$ saturation. This value was calculated using the porosity of the sample, which was calculated from the bulk density using the caliper method and the particle density utilizing the helium pycnometer.

The basic procedure was similar to the Instantaneous Water Immersion Trial. Samples were dried in a $110^{\circ} \mathrm{C}$ for 24 hours, and then allowed to cool to room temperature for several hours. After reaching room temperature, the rocks were all weighed to the nearest 0.01 grams and this weight was recorded as A (to follow the nomenclature established by ASTM C127) (ASTM, 2009). The samples were then covered in room temperature water (around $23^{\circ} \mathrm{C}$ ) and allowed to soak overnight. After a period of 24 hours \pm 4 hours the samples were removed from the water and dried. Drying the sample was intended to remove the film of water clinging to the sample, however not the water actually trapped in the surface pores. The ASTM does allow for blowing air to be used to dry the sample, and in this case, a towel was used. After drying, the sample was weighed again and this weight was recorded as $B$. Immediately after recording the weight, the sample was placed into a second tub of water and the suspended weight of the sample was measured and recorded as C (ASTM, 2009).

ASTM C127 defines the relative density or specific gravity of the sample as:

$$
\begin{aligned}
& \text { Relative Density (Specific Gravity) }=A /(B-C) \\
& \text { Where: } \\
& A=\text { Dry Weight of Sample (g) } \\
& \mathrm{B}=\text { Saturated Surface Dry Weight }(\mathrm{g}) \\
& \mathrm{C}=\text { Submerged Weight of Sample }(\mathrm{g})
\end{aligned}
$$


Absorption can be calculated using the following equation:

$$
\begin{aligned}
& \text { Absorption }(\%)=(\mathrm{B}-\mathrm{A}) / \mathrm{A} \times 100 \% \\
& \qquad \begin{array}{r}
\text { Where: } \\
\qquad=\text { Dry Weight of Sample }(\mathrm{g}) \\
\mathrm{B}=\text { Saturated Surface Dry Weight }(\mathrm{g})
\end{array}
\end{aligned}
$$

These two values were used determine the percent absorption achieved from the SSD method and compared to the 24 Hour Water Immersion Trials.

A large amount of difficulty was encountered when trying to complete this method with samples such as the blast slag. These samples had large surface pores. With the volume of these surface pores being so great, it was difficult to measure the rock in such a way that the water stayed in the pore on its way to the scale.

This procedure and equipment needs are based in part off of ASTM C 127-07: Standard Test Method for Density, Relative Density (Specific Gravity), and Absorption of Coarse Aggregate (ASTM, 2009)

\section{Equipment Needed:}

Scale:

Capable of measuring to 0.01 grams and bottom loading to obtain the suspended weight of the sample.

Lab Table:

Needs to be level and stable to minimize any wobbling from being bumped while trying to obtain a suspended weight of the sample. A hole or some method of attaching the sample basket to the scale to obtain the sample weight needs to be drilled through the top of the desk. The hole needs to be large enough to keep the wire from touching the sides of the desk during testing.

Sample Basket: $\quad$ Basket or hook to place the sample inside while obtaining the suspended weight of the sample during the second phase of testing. Needs to be sturdy enough to completely contain the sample while trying to minimize the profile in the water as the larger the basket the longer it will take for the scale to come to rest after adding in the sample.

Water Tub: $\quad$ Needs to be deep enough to allow the sample to be suspended in the basket while still having the water cover the top. In this case a 20 gallon rubber tub was used. If the same water is to be used later 
a lid is advisable to keep any particles from falling into the water and contaminating the samples.

Another tub is needed to saturate the samples in overnight.

Hydrometer: $\quad$ Needed to check the specific gravity of the water to ensure that it is in fact at $1 \mathrm{~g} / \mathrm{cm} 3$. A $152 \mathrm{H}$ type hydrometer was used for this procedure.

Thermometer: $\quad$ Check that the water is at the needed range in temperature (20$23^{\circ} \mathrm{C}$ or room temperature).

Towels:

Absorbent clothes or air stream to dry samples.

Procedure:

1. Dry the sample at $110^{\circ} \mathrm{C}$ for a period of 24 hours \pm 4 hours. This will remove any trapped moisture from the interior of the sample and ensure that a true dry bulk density is achieved. After drying allow the samples to return to room temperature prior to testing.

2. Determine the dry weight of the sample and record this weight as $A$, in grams.

3. Fill the water tub for the saturation portion of the lab and then cover the sample in water and allow the samples to saturate for 24 hours \pm 4 hours

4. Remove the samples and roll them in a large dry cloth. The aim for this procedure is to remove the film of water from the surface. This is what gives rise to the name Saturated Surface Dry. Remember that the water on the surface is supposed to be removed, but not the water in any of the open pores on the surface.

5. Record the mass of the sample and record the value as B, in grams.

6. Immediately submerge the sample in a tub of water at room temperature $\left(23^{\circ} \mathrm{C}\right)$ and record the weight of the sample suspended in water and record that value as $\mathrm{C}$.

7. The Relative Density (Specific Gravity) can be determined from the follow equation:

Relative Density (Specific Gravity) $=A /(B-C)$

Where:

A= Dry Weight of Sample (g)

$\mathrm{B}=$ Saturated Surface Dry Weight $(\mathrm{g})$

$\mathrm{C}=$ Submerged Weight of Sample $(\mathrm{g})$

8. Absorption can be calculated using the following equation:

Absorption $(\%)=(\mathrm{B}-\mathrm{A}) / \mathrm{A} \times 100 \%$ 
Where:

$$
\begin{aligned}
& A=\text { Dry Weight of Sample }(\mathrm{g}) \\
& \mathrm{B}=\text { Saturated Surface Dry Weight }(\mathrm{g})
\end{aligned}
$$

Results: Results of all testing are shown in the following tables organized by rock type:

Table F-1: Relative Density and Adsorption Values for Granite

\begin{tabular}{|c|c|c|c|c|c|}
\hline $\begin{array}{c}\text { Sample } \\
\text { ID }\end{array}$ & $\begin{array}{c}\text { A: Oven Dry } \\
\text { Weight (g) }\end{array}$ & $\begin{array}{c}\text { B: Saturated } \\
\text { Surface Dry } \\
\text { Weight (g) }\end{array}$ & $\begin{array}{c}\text { C: } \\
\text { Submerged } \\
\text { weight (g) }\end{array}$ & $\begin{array}{c}\text { Relative } \\
\text { Density }\end{array}$ & $\begin{array}{c}\text { Absorption } \\
(\%)\end{array}$ \\
\hline $1-1-1$ & 704.11 & 704.7 & 438.07 & 2.64 & 0.08 \\
\hline $1-1-2$ & 466.41 & 466.71 & 290.88 & 2.65 & 0.06 \\
\hline $1-1-4$ & 442.24 & 444.56 & 277.08 & 2.64 & 0.52 \\
\hline
\end{tabular}

Table F-2: Relative Density and Adsorption Values for Kona Dolomite

\begin{tabular}{|c|c|c|c|c|c|}
\hline $\begin{array}{c}\text { Sample } \\
\text { ID }\end{array}$ & $\begin{array}{c}\text { A: Oven Dry } \\
\text { Weight (g) }\end{array}$ & $\begin{array}{c}\text { B: Saturated } \\
\text { Surface Dry } \\
\text { Weight (g) }\end{array}$ & $\begin{array}{c}\text { C: } \\
\text { Submerged } \\
\text { weight (g) }\end{array}$ & $\begin{array}{c}\text { Relative } \\
\text { Density }\end{array}$ & $\begin{array}{c}\text { Absorption } \\
(\%)\end{array}$ \\
\hline $2-1-1$ & 508.48 & 509.04 & 319.58 & 2.68 & 0.11 \\
\hline $2-1-2$ & 491.06 & 491.41 & 309.52 & 2.70 & 0.07 \\
\hline $2-1-3$ & 510.85 & 511.42 & 325.32 & 2.75 & 0.11 \\
\hline $2-1-4$ & 511.94 & 512.43 & 323.82 & 2.71 & 0.10 \\
\hline $2-2-1$ & 536.08 & 536.39 & 348.92 & 2.86 & 0.06 \\
\hline $2-2-2$ & 518.29 & 518.61 & 331.81 & 2.77 & 0.06 \\
\hline $2-2-3$ & 532.28 & 532.59 & 346.17 & 2.86 & 0.06 \\
\hline $2-2-4$ & 502.92 & 503.31 & 326.28 & 2.84 & 0.08 \\
\hline $2-2-5$ & 502.02 & 502.4 & 326.69 & 2.86 & 0.08 \\
\hline $2-2-6$ & 505.38 & 505.78 & 316.68 & 2.67 & 0.08 \\
\hline
\end{tabular}

Table F-3: Relative Density and Adsorption Values for Pelkie Dolomite

\begin{tabular}{|c|c|c|c|c|c|}
\hline $\begin{array}{c}\text { Sample } \\
\text { ID }\end{array}$ & $\begin{array}{c}\text { A: Oven Dry } \\
\text { Weight (g) }\end{array}$ & $\begin{array}{c}\text { B: Saturated } \\
\text { Surface Dry } \\
\text { Weight (g) }\end{array}$ & $\begin{array}{c}\text { C: } \\
\text { Submerged } \\
\text { weight (g) }\end{array}$ & $\begin{array}{c}\text { Relative } \\
\text { Density }\end{array}$ & $\begin{array}{c}\text { Absorption } \\
(\%)\end{array}$ \\
\hline $3-2-1$ & 257.68 & 261.75 & 165.51 & 2.68 & 1.58 \\
\hline $3-3-1$ & 338.88 & 342.98 & 219.13 & 2.74 & 1.21 \\
\hline
\end{tabular}


Table F- 4: Relative Density and Absorption Values for Various Carbonates

\begin{tabular}{|c|c|c|c|c|c|}
\hline $\begin{array}{c}\text { Sample } \\
\text { ID }\end{array}$ & $\begin{array}{c}\text { A: Oven Dry } \\
\text { Weight (g) }\end{array}$ & $\begin{array}{c}\text { B: Saturated } \\
\text { Surface Dry } \\
\text { Weight (g) }\end{array}$ & $\begin{array}{c}\text { C: } \\
\text { Submerged } \\
\text { weight (g) }\end{array}$ & $\begin{array}{c}\text { Relative } \\
\text { Density }\end{array}$ & $\begin{array}{c}\text { Absorption } \\
(\%)\end{array}$ \\
\hline $4-1-1$ & 456.25 & 457.24 & 292.63 & 2.77 & 0.22 \\
\hline $4-1-2$ & 491.53 & 492.38 & 315.26 & 2.78 & 0.17 \\
\hline $4-1-3$ & 646.71 & 684.73 & 412.27 & 2.37 & 5.88 \\
\hline $4-1-4$ & 794.7 & 796.46 & 508.22 & 2.76 & 0.22 \\
\hline $4-1-5$ & 469.03 & 469.96 & 300.79 & 2.77 & 0.20 \\
\hline $4-2-1$ & 448.66 & 454.39 & 286.94 & 2.68 & 1.28 \\
\hline $4-2-2$ & 454.34 & 460.18 & 290.73 & 2.68 & 1.29 \\
\hline $4-2-3$ & 478.35 & 485.37 & 304.39 & 2.64 & 1.47 \\
\hline $4-3-1$ & 196.13 & 198.32 & 126.36 & 2.73 & 1.12 \\
\hline $4-3-2$ & 361.81 & 366.4 & 233.86 & 2.73 & 1.27 \\
\hline $4-3-3$ & 331.71 & 335.6 & 213.86 & 2.72 & 1.17 \\
\hline $4-4-1$ & 343.91 & 349 & 219.95 & 2.66 & 1.48 \\
\hline $4-4-2$ & 412.3 & 419.15 & 262.09 & 2.63 & 1.66 \\
\hline $4-4-3$ & 381.45 & 386.87 & 243.35 & 2.66 & 1.42 \\
\hline $4-5-1$ & 594.53 & 602.07 & 380.01 & 2.68 & 1.27 \\
\hline
\end{tabular}

Table F-5: Relative Density and Absorption Values for Water Cooled Slag

\begin{tabular}{|c|c|c|c|c|c|}
\hline $\begin{array}{c}\text { Sample } \\
\text { ID }\end{array}$ & $\begin{array}{c}\text { A: Oven Dry } \\
\text { Weight (g) }\end{array}$ & $\begin{array}{c}\text { B: Saturated } \\
\text { Surface Dry } \\
\text { Weight (g) }\end{array}$ & $\begin{array}{c}\text { C: } \\
\text { Submerged } \\
\text { weight (g) }\end{array}$ & $\begin{array}{c}\text { Relative } \\
\text { Density }\end{array}$ & $\begin{array}{c}\text { Absorption } \\
(\%)\end{array}$ \\
\hline $5-1-1$ & 419.28 & 427.61 & 252.16 & 2.39 & 1.99 \\
\hline $5-1-2$ & 395.34 & 409.94 & 239.78 & 2.32 & 3.69 \\
\hline $5-1-3$ & 433.42 & 450.25 & 261.96 & 2.30 & 3.88 \\
\hline $5-1-4$ & 425.71 & 434.38 & 257.38 & 2.41 & 2.04 \\
\hline $5-1-5$ & 341.78 & 354.47 & 207.34 & 2.32 & 3.71 \\
\hline $5-2-1$ & 366.54 & 384.25 & 208.09 & 2.08 & 4.83 \\
\hline $5-2-2$ & 451.24 & 458.34 & 277.29 & 2.49 & 1.57 \\
\hline $5-2-3$ & 507.85 & 521.33 & 307.92 & 2.38 & 2.65 \\
\hline $5-2-5$ & 320.66 & 332.68 & 178.11 & 2.07 & 3.75 \\
\hline $5-3-1$ & 390.38 & 402.69 & 229.32 & 2.25 & 3.15 \\
\hline $5-3-2$ & 366.58 & 382.94 & 205.02 & 2.06 & 4.46 \\
\hline $5-3-3$ & 350.03 & 366.59 & 192.48 & 2.01 & 4.73 \\
\hline
\end{tabular}


Table F-6: Relative Density and Absorption Values for Jacobsville Sandstone

\begin{tabular}{|c|c|c|c|c|c|}
\hline $\begin{array}{c}\text { Sample } \\
\text { ID }\end{array}$ & $\begin{array}{c}\text { A: Oven Dry } \\
\text { Weight (g) }\end{array}$ & $\begin{array}{c}\text { B: Saturated } \\
\text { Surface Dry } \\
\text { Weight (g) }\end{array}$ & $\begin{array}{c}\text { C: } \\
\text { Submerged } \\
\text { weight (g) }\end{array}$ & $\begin{array}{c}\text { Relative } \\
\text { Density }\end{array}$ & $\begin{array}{c}\text { Absorption } \\
(\%)\end{array}$ \\
\hline $6-1-1$ & 390.38 & 398.89 & 222.04 & 2.21 & 2.18 \\
\hline $6-1-2$ & 375.93 & 394.86 & 218.71 & 2.13 & 5.04 \\
\hline $6-1-3$ & 373.42 & 392.93 & 217.42 & 2.13 & 5.22 \\
\hline $6-1-4$ & 377.71 & 397.39 & 220.04 & 2.13 & 5.21 \\
\hline $6-1-5$ & 383.7 & 403.63 & 223.02 & 2.12 & 5.19 \\
\hline $6-1-6$ & 372.61 & 391.09 & 261.53 & 2.88 & 4.96 \\
\hline $6-1-7$ & 388.53 & 407.77 & 225.81 & 2.14 & 4.95 \\
\hline $6-1-8$ & 379.73 & 399.32 & 221.47 & 2.14 & 5.16 \\
\hline $6-1-9$ & 380.95 & 400.76 & 222.21 & 2.13 & 5.20 \\
\hline $6-1-10$ & 377.81 & 398.17 & 220.53 & 2.13 & 5.39 \\
\hline $6-1-11$ & 383.68 & 403.66 & 223.36 & 2.13 & 5.21 \\
\hline $6-1-12$ & 378.33 & 396.71 & 219.72 & 2.14 & 4.86 \\
\hline
\end{tabular}

Table F-7: Relative Density and Absorption Values for Air Cooled Blast Slag

\begin{tabular}{|c|c|c|c|c|c|}
\hline $\begin{array}{c}\text { Sample } \\
\text { ID }\end{array}$ & $\begin{array}{c}\text { A: Oven Dry } \\
\text { Weight (g) }\end{array}$ & $\begin{array}{c}\text { B: Saturated } \\
\text { Surface Dry } \\
\text { Weight (g) }\end{array}$ & $\begin{array}{c}\text { C: } \\
\text { Submerged } \\
\text { weight (g) }\end{array}$ & $\begin{array}{c}\text { Relative } \\
\text { Density }\end{array}$ & $\begin{array}{c}\text { Absorption } \\
(\%)\end{array}$ \\
\hline $7-1$ & 450.35 & 467.29 & 261.21 & 2.19 & 3.76 \\
\hline $7-2$ & 432.34 & 445.24 & 250.46 & 2.22 & 2.98 \\
\hline $7-3$ & 422.49 & 444.62 & 247.22 & 2.14 & 5.24 \\
\hline $7-4$ & 320.63 & 346.52 & 192.54 & 2.08 & 8.07 \\
\hline $7-5$ & 459.83 & 469.09 & 266.68 & 2.27 & 2.01 \\
\hline $7-6$ & 380.56 & 397.23 & 223.24 & 2.19 & 4.38 \\
\hline $7-7$ & 566.06 & 591.36 & 318.04 & 2.07 & 4.47 \\
\hline $7-8$ & 434.34 & 446.53 & 254.38 & 2.26 & 2.81 \\
\hline
\end{tabular}




\section{Appendix G: Helium Pycnometer Results and Run Data}

While many methods are available today for the determination of bulk density, particle density does not have many viable options due to the difficulty of figuring out the volume of the internal pores. The main automatic method available today is the use of a Helium Pycnometer.

A Helium Pycnometer works on the same principal as the ideal gas law. The Pycnometer consists of a sample cup of known volume connected to a supply of helium gas. Once the sample is added to the container helium is pumped into the container. As the helium molecules are incredibly small they are able to infiltrate into all of the internal pores of the sample. The volume of the solid portion of the sample is equal to the difference between the volume of the sample container and the volume calculated during the testing process.

The Helium Pycnometer used for these experiments was an AccuPyc 1330 Pycnometer manufactured by Micromeritics. Figure $\mathrm{H}-1$ below shows the pycnometer used which had a maximum sample volume of $100 \mathrm{~cm}^{3}$ (Micromeritics, 1995). This is one of the largest sample sizes commercially available today.

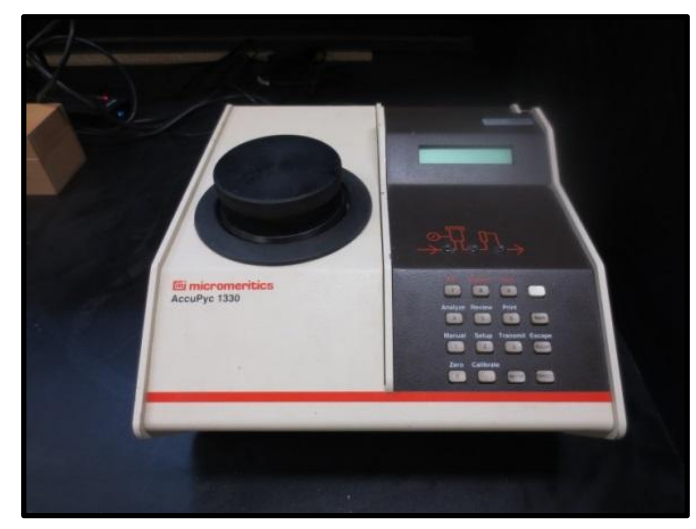

Figure H-1: Picture of the AccuPyc 1330 used during testing.

Table $\mathrm{H}-1$ details the set up parameters used for all the testing using the AccuPyc. Majority of the settings utilized were the default parameters for the pycnometer as suggested in the User Manual. One alteration was the addition of two extra runs so that five values were averaged together instead of three that were the default setting. Purges are used to essentially clean up the sample and to remove any potential for moisture in the sample prior to any runs being initialized. 
Table H-1: Parameters used while operating the AccuPyc 1330

\begin{tabular}{|c|c|}
\hline Parameter & Value \\
\hline Number of Purges & 3 \\
\hline Purge Fill Pressure & $19.500 \mathrm{psig}$ \\
\hline Number of Runs & 5 \\
\hline Run Fill Pressure & $19.500 \mathrm{psig}$ \\
\hline Equilibration Rate & $0.005 \mathrm{psig} / \mathrm{min}$ \\
\hline Use Run Precision & No \\
\hline
\end{tabular}

As recommended in the user's manual the helium used was lab grade that was $99.995 \%$ pure. The tank was fitted with two regulators to ensure that the pressure being inputted into the pycnometer stayed at about 22 psig. Any pressure over 25 psig would vent to the atmosphere wasting the helium gas.

A limitation to this test was the small amount of sample that was able to be tested. With the sample container only large enough for maybe $1 / 3$ of some samples it was difficult to ensure that sufficient mass was tested using this device.

Prior to any testing with the Pycnometer it was calibrated using a standard purchased from Micromeritics. This was necessary as drastic temperature or humidity changes can cause changes the properties of the helium gas to alter.

The samples were all oven dried and weighed prior to being placed into the helium Pyccnometer. AccuPyc's automatically generate a printout of all the settings used during the test, the time it took to run the test as well as the volume and density values calculated for that sample. These printouts and the calibration reports can be found in the following pages. 
Sample 1-1-1 (Granite):

\begin{tabular}{|l|l|l|}
\hline Version Number: & "AccuPyc 1330 V2.01 " & \\
\hline Serial Number: & 0 & \\
\hline Report Type: & Analysis & "12:07:08" \\
\hline Start Time: & $21 / 04 / 13$ & "12:26:56" \\
\hline End Time: & $21 / 04 / 13$ & \\
\hline Temperature: & 26.728868 & \\
\hline Sample ID: & $1-1-1$ & \\
\hline Sample Weight: & 66.459999 & \\
\hline Number of Purges: & 10 & \\
\hline Equilibrium Rate: & 0.005 & \\
\hline Cell Volume: & 110.860016 & \\
\hline Expansion Volume: & 114.226265 & \\
\hline Average Volume: & 25.155966 & \\
\hline Volume Standard Deviation: & 0.019279 & \\
\hline Average Density: & 2.641919 & \\
\hline Density Standard Deviation: & 0.002026 & \\
\hline Number of Runs: & 5 & \\
\hline Run Precision: & 0 & \\
\hline Percent Full: & 0.05 & \\
\hline
\end{tabular}

\begin{tabular}{|c|c|c|c|c|c|}
\hline Run Number & 1 & 2 & 3 & 4 & 5 \\
\hline P1 & 19.494598 & 19.493055 & 19.492804 & 19.4922 & 19.489967 \\
\hline P2 & 8.358577 & 8.356118 & 8.35537 & 8.354886 & 8.354315 \\
\hline Included/Excluded & 1 & 1 & 1 & 1 & 1 \\
\hline Elapsed Time & 612 & 744 & 883 & 1029 & 1180 \\
\hline Volume $\left(\mathrm{cm}^{\wedge} 3\right)$ & 25.123024 & 25.155287 & 25.16679 & 25.17083 & 25.1639 \\
\hline Volume Deviation & -0.032942 & -0.000679 & 0.010824 & 0.014866 & 0.007935 \\
\hline Density (g/cm^3) & 2.645382 & 2.641989 & 2.640782 & 2.640358 & 2.641085 \\
\hline Density Deviation & 0.003463 & 0.00007 & -0.001137 & -0.001561 & -0.000834 \\
\hline
\end{tabular}


Sample 1-1-2 (Granite):

\begin{tabular}{|l|l|l|}
\hline Version Number: & AccuPyc 1330 V2.01 & \\
\hline Serial Number: & 0 & \\
\hline Report Type: & Analysis & \\
\hline Start Time: & $22 / 04 / 13$ & "16:07:35" \\
\hline End Time: & $22 / 04 / 13$ & \\
\hline Temperature: & 26.641188 & \\
\hline Sample ID: & $1-1-2$ & \\
\hline Sample Weight: & 35.57 & \\
\hline Number of Purges: & 10 & \\
\hline Equilibrium Rate: & 0.005 & \\
\hline Cell Volume: & 110.892372 & \\
\hline Expansion Volume: & 114.291046 & \\
\hline Average Volume: & 13.460856 & \\
\hline Volume Standard Deviation: & 0.01315 & \\
\hline Average Density: & 2.642479 & \\
\hline Density Standard Deviation: & 0.002581 & \\
\hline Number of Runs: & 5 & \\
\hline Run Precision: & 0 & \\
\hline Percent Full: & 0.05 & \\
\hline
\end{tabular}

\begin{tabular}{|c|c|c|c|c|c|}
\hline Run Number & 1 & 2 & 3 & 4 & 5 \\
\hline P1 & 19.506248 & 19.507967 & 19.508232 & 19.508343 & 19.50871 \\
\hline P2 & 8.977361 & 8.977415 & 8.977091 & 8.977612 & 8.976719 \\
\hline Included/Excluded & 1 & 1 & 1 & 1 & 1 \\
\hline Elapsed Time & 610 & 774 & 937 & 1095 & 1252 \\
\hline Volume (cm^3) & 13.443148 & 13.457957 & 13.466929 & 13.457465 & 13.47878 \\
\hline Volume Deviation & -0.017709 & -0.002899 & 0.006073 & -0.003391 & 0.017925 \\
\hline Density (g/cm^3) & 2.645958 & 2.643046 & 2.641285 & 2.643143 & 2.638963 \\
\hline Density Deviation & 0.003479 & 0.000567 & -0.001194 & 0.000664 & -0.003516 \\
\hline
\end{tabular}


Sample 1-1-4 (Granite):

\begin{tabular}{|l|l|l|}
\hline Version Number: & "AccuPyc 1330 V2.01 " & \\
\hline Serial Number: & 0 & \\
\hline Report Type: & Analysis & "12:10:31" \\
\hline Start Time: & $13 / 04 / 13$ & "12:36:28" \\
\hline End Time: & $13 / 04 / 13$ & \\
\hline Temperature: & 23.524294 & \\
\hline Sample ID: & $1-1-4$ & \\
\hline Sample Weight: & 27.16 & \\
\hline Number of Purges: & 10 & \\
\hline Equilibrium Rate: & 0.005 & \\
\hline Cell Volume: & 110.828995 & \\
\hline Expansion Volume: & 114.17173 & \\
\hline Average Volume: & 10.26417 & \\
\hline Volume Standard Deviation: & 0.012572 & \\
\hline Average Density: & 2.646101 & \\
\hline Density Standard Deviation: & 0.003243 & \\
\hline Number of Runs: & 5 & \\
\hline Run Precision: & 0 & \\
\hline Percent Full: & 0.05 & \\
\hline
\end{tabular}

\begin{tabular}{|c|c|c|c|c|c|}
\hline Run Number & 1 & 2 & 3 & 4 & 5 \\
\hline P1 & 19.490883 & 19.490217 & 19.49325 & 19.491968 & 19.49182 \\
\hline P2 & 9.128867 & 9.127515 & 9.128286 & 9.12843 & 9.128224 \\
\hline Included/Excluded & 1 & 1 & 1 & 1 & 1 \\
\hline Elapsed Time & 835 & 1007 & 1175 & 1374 & 1549 \\
\hline Volume (cm^3) & 10.244457 & 10.266022 & 10.27943 & 10.264042 & 10.2669 \\
\hline Volume Deviation & -0.019712 & 0.001852 & 0.015255 & -0.000128 & 0.002734 \\
\hline Density (g/cm^3) & 2.65119 & 2.645621 & 2.642171 & 2.646131 & 2.645393 \\
\hline Density Deviation & 0.005088 & -0.00048 & -0.00393 & 0.00003 & -0.00071 \\
\hline
\end{tabular}


Sample 2-1-1 (Kona Dolomite):

\begin{tabular}{|l|l|l|}
\hline Version Number: & "AccuPyc 1330 V2.01 " & \\
\hline Serial Number: & 0 & \\
\hline Report Type: & Analysis & "14:01:47" \\
\hline Start Time: & $18 / 04 / 13$ & "15:29:13" \\
\hline End Time: & $18 / 04 / 13$ & \\
\hline Temperature: & 25.533287 & \\
\hline Sample ID: & $2-1-1$ & \\
\hline Sample Weight: & 85.239998 & \\
\hline Number of Purges: & 10 & \\
\hline Equilibrium Rate: & 0.005 & \\
\hline Cell Volume: & 110.860016 & \\
\hline Expansion Volume: & 114.226265 & \\
\hline Average Volume: & 31.771557 & \\
\hline Volume Standard Deviation: & 0.023627 & \\
\hline Average Density: & 2.682904 & \\
\hline Density Standard Deviation: & 0.001995 & \\
\hline Number of Runs: & 5 & \\
\hline Run Precision: & 0 & \\
\hline Percent Full: & 0.05 & \\
\hline
\end{tabular}

\begin{tabular}{|c|c|c|c|c|c|}
\hline Run Number & 1 & 2 & 3 & 4 & 5 \\
\hline P1 & 19.490507 & 19.490053 & 19.490267 & 19.49097 & 19.490749 \\
\hline P2 & 7.972277 & 7.97475 & 7.974196 & 7.975629 & 7.9727 \\
\hline Included/Excluded & 1 & 1 & 1 & 1 & 1 \\
\hline Elapsed Time & 3706 & 4093 & 4477 & 4852 & 5238 \\
\hline Volume (cm^3) & 31.798965 & 31.754333 & 31.765102 & 31.74586 & 31.793531 \\
\hline Volume Deviation & 0.027409 & -0.017223 & -0.006454 & -0.025702 & 0.021975 \\
\hline Density (g/cm^3) & 2.68059 & 2.684358 & 2.683448 & 2.685075 & 2.681048 \\
\hline Density Deviation & -0.002314 & 0.001454 & 0.000544 & 0.002171 & -0.001855 \\
\hline
\end{tabular}


Sample 2-1-2 (Kona Dolomite):

\begin{tabular}{|l|l|l|}
\hline Version Number: & "AccuPyc 1330 V2.01 " & \\
\hline Serial Number: & 0 & \\
\hline Report Type: & Analysis & "11:11:10" \\
\hline Start Time: & $19 / 04 / 13$ & \\
\hline End Time: & $19 / 04 / 13$ & \\
\hline Temperature: & 25.761564 & \\
\hline Sample ID: & $2-1-2$ & \\
\hline Sample Weight: & 57.240002 & \\
\hline Number of Purges: & 10 & \\
\hline Equilibrium Rate: & 0.005 & \\
\hline Cell Volume: & 110.860016 & \\
\hline Expansion Volume: & 114.226265 & \\
\hline Average Volume: & 21.330393 & \\
\hline Volume Standard Deviation: & 0.014075 & \\
\hline Average Density: & 2.683496 & \\
\hline Density Standard Deviation: & 0.00177 & \\
\hline Number of Runs: & 5 & \\
\hline Run Precision: & 0 & \\
\hline Percent Full: & 0.05 & \\
\hline
\end{tabular}

\begin{tabular}{|c|c|c|c|c|c|}
\hline Run Number & 1 & 2 & 3 & 4 & 5 \\
\hline P1 & 19.490782 & 19.491814 & 19.491919 & 19.50836 & 19.509865 \\
\hline P2 & 8.56426 & 8.563391 & 8.565283 & 8.572509 & 8.572528 \\
\hline Included/Excluded & 1 & 1 & 1 & 1 & 1 \\
\hline Elapsed Time & 829 & 995 & 1163 & 1331 & 1494 \\
\hline Volume (cm^3) & 21.328932 & 21.353584 & 21.319164 & 21.31917 & 21.331106 \\
\hline Volume Deviation & -0.001461 & 0.023191 & -0.011229 & -0.011219 & 0.000713 \\
\hline Density (g/cm^3) & 2.683679 & 2.68058 & 2.684908 & 2.684907 & 2.683405 \\
\hline Density Deviation & 0.000183 & -0.002916 & 0.001412 & 0.001411 & -0.000091 \\
\hline
\end{tabular}


Sample 2-1-3 (Kona Dolomite):

\begin{tabular}{|l|l|l|}
\hline Version Number: & "AccuPyc 1330 V2.01 " & \\
\hline Serial Number: & 0 & \\
\hline Report Type: & Analysis & "10:36:28" \\
\hline Start Time: & $21 / 04 / 13$ & "10:54:26" \\
\hline End Time: & $21 / 04 / 13$ & \\
\hline Temperature: & 26.39246 & \\
\hline Sample ID: & $2-1-3$ & \\
\hline Sample Weight: & 81.459999 & \\
\hline Number of Purges: & 10 & \\
\hline Equilibrium Rate: & 0.005 & \\
\hline Cell Volume: & 110.860016 & \\
\hline Expansion Volume: & 114.226265 & \\
\hline Average Volume: & 29.573599 & \\
\hline Volume Standard Deviation: & 0.025434 & \\
\hline Average Density: & 2.754485 & \\
\hline Density Standard Deviation: & 0.002371 & \\
\hline Number of Runs: & 5 & \\
\hline Run Precision: & 0 & \\
\hline Percent Full: & 0.05 & \\
\hline
\end{tabular}

\begin{tabular}{|c|c|c|c|c|c|}
\hline Run Number & 1 & 2 & 3 & 4 & 5 \\
\hline P1 & 19.501127 & 19.501196 & 19.50219 & 19.50132 & 19.502047 \\
\hline P2 & 8.110228 & 8.107699 & 8.107484 & 8.106362 & 8.108132 \\
\hline Included/Excluded & 1 & 1 & 1 & 1 & 1 \\
\hline Elapsed Time & 519 & 654 & 788 & 933 & 1070 \\
\hline Volume (cm^3) & 29.531847 & 29.575731 & 29.586517 & 29.59953 & 29.574369 \\
\hline Volume Deviation & -0.041752 & 0.002132 & 0.012918 & 0.02593 & 0.000771 \\
\hline Density (g/cm^3) & 2.758378 & 2.754285 & 2.753281 & 2.752071 & 2.754412 \\
\hline Density Deviation & 0.003893 & -0.0002 & -0.001204 & -0.002414 & -0.000073 \\
\hline
\end{tabular}


Sample 2-1-4 (Kona Dolomite):

\begin{tabular}{|l|l|l|}
\hline Version Number: & "AccuPyc 1330 V2.01 " & \\
\hline Serial Number: & 0 & \\
\hline Report Type: & Analysis & \\
\hline Start Time: & $17 / 04 / 13$ & "14:46:39" \\
\hline End Time: & $17 / 04 / 13$ & \\
\hline Temperature: & 25.678741 & \\
\hline Sample ID: & $2-1-4$ & \\
\hline Sample Weight: & 95.260002 & \\
\hline Number of Purges: & 10 & \\
\hline Equilibrium Rate: & 0.005 & \\
\hline Cell Volume: & 110.823776 & \\
\hline Expansion Volume: & 114.171974 & \\
\hline Average Volume: & 34.614441 & \\
\hline Volume Standard Deviation: & 0.020371 & \\
\hline Average Density: & 2.752031 & \\
\hline Density Standard Deviation: & 0.00162 & \\
\hline Number of Runs: & 5 & \\
\hline Run Precision: & 0 & \\
\hline Percent Full: & 0.05 & \\
\hline
\end{tabular}

\begin{tabular}{|c|c|c|c|c|c|}
\hline Run Number & 1 & 2 & 3 & 4 & 5 \\
\hline P1 & 19.490662 & 19.490324 & 19.490614 & 19.48995 & 19.490662 \\
\hline P2 & 7.801488 & 7.803502 & 7.800636 & 7.802847 & 7.801491 \\
\hline Included/Excluded & 1 & 1 & 1 & 1 & 1 \\
\hline Elapsed Time & 2287 & 2549 & 2819 & 3086 & 3357 \\
\hline Volume (cm^3) & 34.624088 & 34.589088 & 34.637657 & 34.59733 & 34.624043 \\
\hline Volume Deviation & 0.009647 & -0.025352 & 0.023216 & -0.017113 & 0.009602 \\
\hline Density (g/cm^3) & 2.751264 & 2.754048 & 2.750186 & 2.753392 & 2.751267 \\
\hline Density Deviation & -0.000768 & 0.002017 & -0.001845 & 0.001361 & -0.000764 \\
\hline
\end{tabular}


Sample 2-2-1 (Kona Dolomite):

\begin{tabular}{|l|l|l|}
\hline Version Number: & "AccuPyc 1330 V2.01 " & \\
\hline Serial Number: & 0 & \\
\hline Report Type: & Analysis & "15:45:42" \\
\hline Start Time: & $17 / 04 / 13$ & "16:42:02" \\
\hline End Time: & $17 / 04 / 13$ & \\
\hline Temperature: & 25.994955 & \\
\hline Sample ID: & $2-2-1$ & \\
\hline Sample Weight: & 88.910004 & \\
\hline Number of Purges: & 10 & \\
\hline Equilibrium Rate: & 0.005 & \\
\hline Cell Volume: & 110.823776 & \\
\hline Expansion Volume: & 114.171974 & \\
\hline Average Volume: & 31.138245 & \\
\hline Volume Standard Deviation: & 0.019351 & \\
\hline Average Density: & 2.855332 & \\
\hline Density Standard Deviation: & 0.001775 & \\
\hline Number of Runs: & 5 & \\
\hline Run Precision: & 0 & \\
\hline Percent Full: & 0.05 & \\
\hline
\end{tabular}

\begin{tabular}{|c|c|c|c|c|c|}
\hline Run Number & 1 & 2 & 3 & 4 & 5 \\
\hline P1 & 19.490303 & 19.490318 & 19.490793 & 19.4909 & 19.49036 \\
\hline P2 & 8.012062 & 8.013189 & 8.010944 & 8.010512 & 8.011417 \\
\hline Included/Excluded & 1 & 1 & 1 & 1 & 1 \\
\hline Elapsed Time & 2200 & 2483 & 2778 & 3075 & 3372 \\
\hline Volume (cm^3) & 31.129253 & 31.110317 & 31.151531 & 31.15958 & 31.140537 \\
\hline Volume Deviation & -0.008991 & -0.027927 & 0.013287 & 0.021336 & 0.002293 \\
\hline Density (g/cm^3) & 2.856156 & 2.857894 & 2.854113 & 2.853376 & 2.855121 \\
\hline Density Deviation & 0.000824 & 0.002562 & -0.001219 & -0.001956 & -0.000211 \\
\hline
\end{tabular}


Sample 2-2-2 (Kona Dolomite):

\begin{tabular}{|l|l|l|}
\hline Version Number: & "AccuPyc 1330 V2.01 " & \\
\hline Serial Number: & 0 & \\
\hline Report Type: & Analysis & \\
\hline Start Time: & $18 / 04 / 13$ & "16:00:01" \\
\hline End Time: & $18 / 04 / 13$ & \\
\hline Temperature: & 25.901649 & \\
\hline Sample ID: & $2-2-2$ & \\
\hline Sample Weight: & 87.410004 & \\
\hline Number of Purges: & 10 & \\
\hline Equilibrium Rate: & 0.005 & \\
\hline Cell Volume: & 110.860016 & \\
\hline Expansion Volume: & 114.226265 & \\
\hline Average Volume: & 32.053284 & \\
\hline Volume Standard Deviation: & 0.022027 & \\
\hline Average Density: & 2.727023 & \\
\hline Density Standard Deviation: & 0.001874 & \\
\hline Number of Runs: & 5 & \\
\hline Run Precision: & 0 & \\
\hline Percent Full: & 0.05 & \\
\hline
\end{tabular}

\begin{tabular}{|c|c|c|c|c|c|}
\hline Run Number & 1 & 2 & 3 & 4 & 5 \\
\hline P1 & 19.492153 & 19.492559 & 19.490643 & 19.49392 & 19.49284 \\
\hline P2 & 7.957523 & 7.9585 & 7.955284 & 7.958322 & 7.95979 \\
\hline Included/Excluded & 1 & 1 & 1 & 1 & 1 \\
\hline Elapsed Time & 3030 & 3379 & 3722 & 4073 & 4421 \\
\hline Volume (cm^3) & 32.05748 & 32.043896 & 32.084621 & 32.05619 & 32.024223 \\
\hline Volume Deviation & 0.004196 & -0.009388 & 0.031338 & 0.002911 & -0.02906 \\
\hline Density (g/cm^3) & 2.726665 & 2.727821 & 2.724358 & 2.726774 & 2.729496 \\
\hline Density Deviation & -0.000358 & 0.000798 & -0.002665 & -0.000249 & 0.002474 \\
\hline
\end{tabular}


Sample 2-2-3 (Kona Dolomite):

\begin{tabular}{|l|l|l|}
\hline Version Number: & "AccuPyc 1330 V2.01 " & \\
\hline Serial Number: & 0 & \\
\hline Report Type: & Analysis & \\
\hline Start Time: & $17 / 04 / 13$ & "17:44:03" \\
\hline End Time: & $17 / 04 / 13$ & \\
\hline Temperature: & 26.47426 & \\
\hline Sample ID: & $2-2-3$ & \\
\hline Sample Weight: & 98.449997 & \\
\hline Number of Purges: & 10 & \\
\hline Equilibrium Rate: & 0.005 & \\
\hline Cell Volume: & 110.823776 & \\
\hline Expansion Volume: & 114.171974 & \\
\hline Average Volume: & 34.766224 & \\
\hline Volume Standard Deviation: & 0.015749 & \\
\hline Average Density: & 2.831772 & \\
\hline Density Standard Deviation: & 0.001282 & \\
\hline Number of Runs: & 5 & \\
\hline Run Precision: & 0 & \\
\hline Percent Full: & 0.05 & \\
\hline
\end{tabular}

\begin{tabular}{|c|c|c|c|c|c|}
\hline Run Number & 1 & 2 & 3 & 4 & 5 \\
\hline P1 & 19.490053 & 19.490564 & 19.490498 & 19.48989 & 19.490881 \\
\hline P2 & 7.791025 & 7.793712 & 7.792534 & 7.792372 & 7.793563 \\
\hline Included/Excluded & 1 & 1 & 1 & 1 & 1 \\
\hline Elapsed Time & 2286 & 2566 & 2847 & 3137 & 3424 \\
\hline Volume (cm^3) & 34.790398 & 34.750027 & 34.768745 & 34.76745 & 34.754498 \\
\hline Volume Deviation & 0.024174 & -0.016197 & 0.002522 & 0.001221 & -0.011726 \\
\hline Density (g/cm³) & 2.829804 & 2.833091 & 2.831566 & 2.831672 & 2.832727 \\
\hline Density Deviation & -0.001968 & 0.001319 & -0.000206 & -0.0001 & 0.000955 \\
\hline
\end{tabular}


Sample 2-2-4 (Kona Dolomite):

\begin{tabular}{|l|l|l|}
\hline Version Number: & "AccuPyc 1330 V2.01 " & \\
\hline Serial Number: & 0 & \\
\hline Report Type: & Analysis & \\
\hline Start Time: & $18 / 04 / 13$ & "12:36:34" \\
\hline End Time: & $18 / 04 / 13$ & \\
\hline Temperature: & 25.399593 & \\
\hline Sample ID: & $2-2-4$ & \\
\hline Sample Weight: & 104.330002 & \\
\hline Number of Purges: & 10 & \\
\hline Equilibrium Rate: & 0.005 & \\
\hline Cell Volume: & 110.860016 & \\
\hline Expansion Volume: & 114.226265 & \\
\hline Average Volume: & 36.574268 & \\
\hline Volume Standard Deviation: & 0.049812 & \\
\hline Average Density: & 2.852556 & \\
\hline Density Standard Deviation: & 0.003878 & \\
\hline Number of Runs: & 5 & \\
\hline Run Precision: & 0 & \\
\hline Percent Full: & 0.05 & \\
\hline
\end{tabular}

\begin{tabular}{|c|c|c|c|c|c|}
\hline Run Number & 1 & 2 & 3 & 4 & 5 \\
\hline P1 & 19.490286 & 19.491051 & 19.491337 & 19.48991 & 19.491386 \\
\hline P2 & 7.681325 & 7.682551 & 7.681762 & 7.674742 & 7.682691 \\
\hline Included/Excluded & 1 & 1 & 1 & 1 & 1 \\
\hline Elapsed Time & 3368 & 3749 & 4137 & 4536 & 4922 \\
\hline Volume (cm^3) & 36.559738 & 36.544971 & 36.55938 & 36.66241 & 36.544853 \\
\hline Volume Deviation & -0.01453 & -0.029297 & -0.014889 & 0.088139 & -0.029415 \\
\hline Density (g/cm³) & 2.853686 & 2.854839 & 2.853714 & 2.845694 & 2.854848 \\
\hline Density Deviation & 0.00113 & 0.002283 & 0.001158 & -0.006862 & 0.002292 \\
\hline
\end{tabular}


Sample 2-2-5 (Kona Dolomite):

\begin{tabular}{|l|l|l|}
\hline Version Number: & "AccuPyc 1330 V2.01 " & \\
\hline Serial Number: & 0 & \\
\hline Report Type: & Analysis & \\
\hline Start Time: & $17 / 04 / 13$ & "16:45:34" \\
\hline End Time: & $17 / 04 / 13$ & \\
\hline Temperature: & 26.260044 & \\
\hline Sample ID: & $2-2-5$ & \\
\hline Sample Weight: & 95.379997 & \\
\hline Number of Purges: & 10 & \\
\hline Equilibrium Rate: & 0.005 & \\
\hline Cell Volume: & 110.823776 & \\
\hline Expansion Volume: & 114.171974 & \\
\hline Average Volume: & 33.319839 & \\
\hline Volume Standard Deviation: & 0.008407 & \\
\hline Average Density: & 2.862559 & \\
\hline Density Standard Deviation: & 0.000722 & \\
\hline Number of Runs: & 5 & \\
\hline Run Precision: & 0 & \\
\hline Percent Full: & 0.05 & \\
\hline
\end{tabular}

\begin{tabular}{|c|c|c|c|c|c|}
\hline Run Number & 1 & 2 & 3 & 4 & 5 \\
\hline P1 & 19.490566 & 19.490929 & 19.491379 & 19.49202 & 19.491199 \\
\hline P2 & 7.880368 & 7.881481 & 7.880833 & 7.88188 & 7.881699 \\
\hline Included/Excluded & 1 & 1 & 1 & 1 & 1 \\
\hline Elapsed Time & 2209 & 2481 & 2757 & 3041 & 3316 \\
\hline Volume (cm^3) & 33.330086 & 33.314121 & 33.327824 & 33.31484 & 33.31234 \\
\hline Volume Deviation & 0.010246 & -0.005718 & 0.007984 & -0.005005 & -0.0075 \\
\hline Density (g/cm^3) & 2.861679 & 2.86305 & 2.861873 & 2.862989 & 2.863203 \\
\hline Density Deviation & -0.00088 & 0.000491 & -0.000686 & 0.00043 & 0.000644 \\
\hline
\end{tabular}


Sample 2-2-6 (Kona Dolomite):

\begin{tabular}{|l|l|l|}
\hline Version Number: & "AccuPyc 1330 V2.01 " & \\
\hline Serial Number: & 0 & \\
\hline Report Type: & Analysis & \\
\hline Start Time: & $17 / 04 / 13$ & "13:37:33" \\
\hline End Time: & $17 / 04 / 13$ & \\
\hline Temperature: & 25.456343 & \\
\hline Sample ID: & $2-2-6$ & \\
\hline Sample Weight: & 91.660004 & \\
\hline Number of Purges: & 10 & \\
\hline Equilibrium Rate: & 0.005 & \\
\hline Cell Volume: & 110.823776 & \\
\hline Expansion Volume: & 114.171974 & \\
\hline Average Volume: & 33.579914 & \\
\hline Volume Standard Deviation: & 0.012925 & \\
\hline Average Density: & 2.729608 & \\
\hline Density Standard Deviation: & 0.001051 & \\
\hline Number of Runs: & 5 & \\
\hline Run Precision: & 0 & \\
\hline Percent Full: & 0.05 & \\
\hline
\end{tabular}

\begin{tabular}{|c|c|c|c|c|c|}
\hline Run Number & 1 & 2 & 3 & 4 & 5 \\
\hline P1 & 19.490856 & 19.490616 & 19.490355 & 19.49093 & 19.49057 \\
\hline P2 & 7.86497 & 7.864899 & 7.864359 & 7.866621 & 7.865424 \\
\hline Included/Excluded & 1 & 1 & 1 & 1 & 1 \\
\hline Elapsed Time & 2358 & 2647 & 2942 & 3232 & 3524 \\
\hline Volume (cm^3) & 33.585869 & 33.585434 & 33.592594 & 33.55918 & 33.576496 \\
\hline Volume Deviation & 0.005955 & 0.00552 & 0.01268 & -0.020733 & -0.003418 \\
\hline Density (g/cm^3) & 2.729124 & 2.729159 & 2.728578 & 2.731294 & 2.729886 \\
\hline Density Deviation & -0.000484 & -0.000449 & -0.001031 & 0.001686 & 0.000278 \\
\hline
\end{tabular}


Sample 3-2-1 (Pelkie Limestone):

\begin{tabular}{|l|l|l|}
\hline Version Number: & "AccuPyc 1330 V2.01 " & \\
\hline Serial Number: & 0 & \\
\hline Report Type: & Analysis & \\
\hline Start Time: & $13 / 04 / 13$ & "14:59:15" \\
\hline End Time: & $13 / 04 / 13$ & \\
\hline Temperature: & 25.142174 & \\
\hline Sample ID: & $3-2-1$ & \\
\hline Sample Weight: & 55.360001 & \\
\hline Number of Purges: & 10 & \\
\hline Equilibrium Rate: & 0.005 & \\
\hline Cell Volume: & 110.828995 & \\
\hline Expansion Volume: & 114.17173 & \\
\hline Average Volume: & 19.736273 & \\
\hline Volume Standard Deviation: & 0.014655 & \\
\hline Average Density: & 2.804989 & \\
\hline Density Standard Deviation: & 0.002082 & \\
\hline Number of Runs: & 5 & \\
\hline Run Precision: & 0 & \\
\hline Percent Full: & 0.05 & \\
\hline
\end{tabular}

\begin{tabular}{|c|c|c|c|c|c|}
\hline Run Number & 1 & 2 & 3 & 4 & 5 \\
\hline P1 & 19.49719 & 19.49552 & 19.49716 & 19.49589 & 19.49751 \\
\hline P2 & 8.652912 & 8.652621 & 8.651331 & 8.651608 & 8.652872 \\
\hline Included/excluded & 1 & 1 & 1 & 1 & 1 \\
\hline Elapsed time & 879 & 1061 & 1237 & 1417 & 1603 \\
\hline Volume $\mathrm{cm}^{\wedge} 3$ & 19.72861 & 19.72009 & 19.75825 & 19.74241 & 19.73201 \\
\hline Volume deviation & -0.00766 & -0.01618 & 0.021973 & 0.006134 & -0.00426 \\
\hline Density g/cm^3 & 2.806077 & 2.807289 & 2.801868 & 2.804116 & 2.805593 \\
\hline Density deviation & 0.001088 & 0.0023 & -0.00312 & -0.00087 & 0.000605 \\
\hline
\end{tabular}


Sample 3-3-1 (Pelkie Limestone):

\begin{tabular}{|l|l|l|}
\hline Version Number: & "AccuPyc 1330 V2.01 " & \\
\hline Serial Number: & 0 & \\
\hline Report Type: & Analysis & "13:25:50" \\
\hline Start Time: & $13 / 04 / 13$ & "13:52:29" \\
\hline End Time: & $13 / 04 / 13$ & \\
\hline Temperature: & 24.727543 & \\
\hline Sample ID: & $3-3-1$ & \\
\hline Sample Weight: & 31.99 & \\
\hline Number of Purges: & 10 & \\
\hline Equilibrium Rate: & 0.005 & \\
\hline Cell Volume: & 110.828995 & \\
\hline Expansion Volume: & 114.17173 & \\
\hline Average Volume: & 11.295753 & \\
\hline Volume Standard Deviation: & 0.007921 & \\
\hline Average Density: & 2.832039 & \\
\hline Density Standard Deviation: & 0.001987 & \\
\hline Number of Runs: & 5 & \\
\hline Run Precision: & 0 & \\
\hline Percent Full: & 0.05 & \\
\hline
\end{tabular}

\begin{tabular}{|c|c|c|c|c|c|}
\hline Run Number & 1 & 2 & 3 & 4 & 5 \\
\hline P1 & 19.490465 & 19.494747 & 19.493801 & 19.49387 & 19.491663 \\
\hline P2 & 9.078282 & 9.079873 & 9.079129 & 9.078968 & 9.077929 \\
\hline Included/Excluded & 1 & 1 & 1 & 1 & 1 \\
\hline Elapsed Time & 884 & 1070 & 1249 & 1422 & 1591 \\
\hline Volume (cm^3) & 11.283758 & 11.292043 & 11.298265 & 11.30225 & 11.302449 \\
\hline Volume Deviation & -0.011994 & -0.00371 & 0.002513 & 0.006495 & 0.006697 \\
\hline Density (g/cm^3) & 2.835048 & 2.832968 & 2.831408 & 2.830411 & 2.83036 \\
\hline Density Deviation & 0.003009 & 0.000929 & -0.000631 & -0.001628 & -0.001679 \\
\hline
\end{tabular}


Sample 4-1-1 (Various Carbonates):

\begin{tabular}{|l|l|l|}
\hline Version Number: & "AccuPyc 1330 V2.01 " & \\
\hline Serial Number: & 0 & \\
\hline Report Type: & Analysis & \\
\hline Start Time: & $14 / 04 / 13$ & "13:40:04" \\
\hline End Time: & $14 / 04 / 13$ & \\
\hline Temperature: & 27.199993 & \\
\hline Sample ID: & $4-1-1$ & \\
\hline Sample Weight: & 88.190002 & \\
\hline Number of Purges: & 10 & \\
\hline Equilibrium Rate: & 0.005 & \\
\hline Cell Volume: & 110.838661 & \\
\hline Expansion Volume: & 114.219429 & \\
\hline Average Volume: & 31.15279 & \\
\hline Volume Standard Deviation: & 0.014265 & \\
\hline Average Density: & 2.830887 & \\
\hline Density Standard Deviation: & 0.001296 & \\
\hline Number of Runs: & 5 & \\
\hline Run Precision: & 0 & \\
\hline Percent Full: & 0.05 & \\
\hline
\end{tabular}

\begin{tabular}{|c|c|c|c|c|c|}
\hline Run Number & 1 & 2 & 3 & 4 & 5 \\
\hline P1 & 19.495092 & 19.492453 & 19.494926 & 19.49595 & 19.493811 \\
\hline P2 & 8.011886 & 8.011587 & 8.011554 & 8.01158 & 8.009851 \\
\hline Included/Excluded & 1 & 1 & 1 & 1 & 1 \\
\hline Elapsed Time & 1111 & 1305 & 1497 & 1691 & 1881 \\
\hline Volume (cm^3) & 31.147245 & 31.133965 & 31.151697 & 31.15833 & 31.172714 \\
\hline Volume Deviation & -0.005545 & -0.018826 & -0.001093 & 0.005537 & 0.019924 \\
\hline Density (g/cm^3) & 2.83139 & 2.832598 & 2.830985 & 2.830383 & 2.829077 \\
\hline Density Deviation & 0.000504 & 0.001711 & 0.000099 & -0.000504 & -0.00181 \\
\hline
\end{tabular}


Sample 4-1-2 (Various Carbonates):

\begin{tabular}{|l|l|l|}
\hline Version Number: & "AccuPyc 1330 V2.01 " & \\
\hline Serial Number: & 0 & \\
\hline Report Type: & Analysis & \\
\hline Start Time: & $13 / 06 / 13$ & "10:32:16" \\
\hline End Time: & $13 / 06 / 13$ & \\
\hline Temperature: & 24.84258 & \\
\hline Sample ID: & $4-1-2$ & \\
\hline Sample Weight: & 84.45 & \\
\hline Number of Purges: & 10 & \\
\hline Equilibrium Rate: & 0.005 & \\
\hline Cell Volume: & 110.8744 & \\
\hline Expansion Volume: & 114.2415 & \\
\hline Average Volume: & 29.83144 & \\
\hline Volume Standard Deviation: & 0.019913 & \\
\hline Average Density: & 2.830907 & \\
\hline Density Standard Deviation: & 0.001891 & \\
\hline Number of Runs: & 5 & \\
\hline Run Precision: & 0 & \\
\hline Percent Full: & 0.05 & \\
\hline
\end{tabular}

\begin{tabular}{|c|r|l|l|r|r|}
\hline Run Number & 1 & 2 & 3 & 4 & \multicolumn{1}{l|}{5} \\
\hline P1 & 19.4881 & 19.48874 & 19.48778 & 19.4894 & 19.48856 \\
\hline P2 & 8.089498 & 8.087571 & 8.086345 & 8.088078 & 8.087106 \\
\hline Included/excluded & 1 & 1 & 1 & 1 & 1 \\
\hline Elapsed time & 543 & 682 & 825 & 981 & 1142 \\
\hline Volume cm^3 & 29.79803 & 29.83558 & 29.84976 & 29.83156 & 29.84226 \\
\hline Volume deviation & -0.03341 & 0.004139 & 0.018324 & 0.000126 & 0.01082 \\
\hline Density g/cm^3 & 2.83408 & 2.830513 & 2.829168 & 2.830894 & 2.82988 \\
\hline Density deviation & 0.003173 & -0.00039 & -0.00174 & $-1.3 \mathrm{E}-05$ & -0.00103 \\
\hline
\end{tabular}


Sample 4-1-3 (Various Carbonates):

\begin{tabular}{|c|c|c|}
\hline Version Number: & "AccuPyc 1330 V2.01" & \\
\hline Serial Number: & 0 & \\
\hline Report Type: & Analysis & \\
\hline Start Time: & $13 / 06 / 13$ & "10:57:59" \\
\hline End Time: & $13 / 06 / 13$ & "11:17:04" \\
\hline Temperature: & 24.85434 & \\
\hline Sample ID: & $4-1-3$ & \\
\hline Sample Weight: & 107.28 & \\
\hline Number of Purges: & 10 & \\
\hline Equilibrium Rate: & 0.005 & \\
\hline Cell Volume: & 110.8744 & \\
\hline Expansion Volume: & 114.2415 & \\
\hline Average Volume: & 37.92412 & \\
\hline Volume Standard Deviation: & 0.02716 & \\
\hline Average Density: & 2.828808 & \\
\hline Density Standard Deviation: & 0.002027 & \\
\hline Number of Runs: & 5 & \\
\hline Run Precision: & 0 & \\
\hline Percent Full: & 0.05 & \\
\hline
\end{tabular}

\begin{tabular}{|c|r|r|r|r|r|}
\hline Run Number & 1 & 2 & 3 & 4 & 5 \\
\hline P1 & 19.48811 & 19.48717 & 19.48588 & 19.48508 & 19.48561 \\
\hline P2 & 7.597388 & 7.594311 & 7.593874 & 7.592749 & 7.591702 \\
\hline Included/excluded & 1 & 1 & 1 & 1 & 1 \\
\hline Elapsed time & 542 & 686 & 835 & 989 & 1137 \\
\hline Volume cm^3 & 37.88154 & 37.92421 & 37.92321 & 37.93596 & 37.95569 \\
\hline Volume deviation & -0.04258 & 0.000088 & -0.00092 & 0.011841 & 0.031563 \\
\hline Density g/cm^3 & 2.831986 & 2.8288 & 2.828875 & 2.827924 & 2.826454 \\
\hline Density deviation & 0.003179 & $-8 \mathrm{E}-06$ & 0.000067 & -0.00088 & -0.00235 \\
\hline
\end{tabular}


Sample 4-1-4 (Various Carbonates):

\begin{tabular}{|l|l|l|}
\hline Version Number: & "AccuPyc 1330 V2.01 " & \\
\hline Serial Number: & 0 & \\
\hline Report Type: & Analysis & \\
\hline Start Time: & $13 / 06 / 13$ & "12:39:29" \\
\hline End Time: & $13 / 06 / 13$ & \\
\hline Temperature: & 24.95838 & \\
\hline Sample ID: & $4-1-4$ & \\
\hline Sample Weight: & 96.38 & \\
\hline Number of Purges: & 10 & \\
\hline Equilibrium Rate: & 0.005 & \\
\hline Cell Volume: & 110.8744 & \\
\hline Expansion Volume: & 114.2415 & \\
\hline Average Volume: & 34.07069 & \\
\hline Volume Standard Deviation: & 0.030046 & \\
\hline Average Density: & 2.828826 & \\
\hline Density Standard Deviation: & 0.002495 & \\
\hline Number of Runs: & 5 & \\
\hline Run Precision: & 0 & \\
\hline Percent Full: & 0.05 & \\
\hline
\end{tabular}

\begin{tabular}{|c|c|c|c|c|c|}
\hline Run Number & 1 & 2 & 3 & 4 & 5 \\
\hline P1 & 19.49275 & 19.49863 & 19.49268 & 19.4975 & 19.493 \\
\hline P2 & 7.839015 & 7.839588 & 7.836192 & 7.837575 & 7.834184 \\
\hline Included/excluded & 1 & 1 & 1 & 1 & 1 \\
\hline Elapsed time & 622 & 794 & 979 & 1171 & 1355 \\
\hline Volume cm^3 & 34.02849 & 34.0579 & 34.07434 & 34.0834 & 34.10932 \\
\hline Volume deviation & -0.0422 & -0.01279 & 0.003651 & 0.012707 & 0.038628 \\
\hline Density g/cm^3 & 2.832332 & 2.829886 & 2.828521 & 2.82777 & 2.825621 \\
\hline Density deviation & 0.003506 & 0.00106 & -0.00031 & -0.00106 & -0.00321 \\
\hline
\end{tabular}


Sample 4-1-5 (Various Carbonates):

\begin{tabular}{|l|l|l|}
\hline Version Number: & "AccuPyc 1330 V2.01 " & \\
\hline Serial Number: & 0 & \\
\hline Report Type: & Analysis & \\
\hline Start Time: & $21 / 04 / 13$ & "12:29:57" \\
\hline End Time: & $21 / 04 / 13$ & \\
\hline Temperature: & 26.813738 & \\
\hline Sample ID: & $4-1-5$ & \\
\hline Sample Weight: & 86.309998 & \\
\hline Number of Purges: & 10 & \\
\hline Equilibrium Rate: & 0.005 & \\
\hline Cell Volume: & 110.860016 & \\
\hline Expansion Volume: & 114.226265 & \\
\hline Average Volume: & 30.534632 & \\
\hline Volume Standard Deviation: & 0.029085 & \\
\hline Average Density: & 2.826628 & \\
\hline Density Standard Deviation: & 0.002694 & \\
\hline Number of Runs: & 5 & \\
\hline Run Precision: & 0 & \\
\hline Percent Full: & 0.05 & \\
\hline
\end{tabular}

\begin{tabular}{|c|c|c|c|c|c|}
\hline Run Number & 1 & 2 & 3 & 4 & 5 \\
\hline P1 & 19.50543 & 19.50713 & 19.502541 & 19.5011 & 19.502504 \\
\hline P2 & 8.055882 & 8.054405 & 8.052176 & 8.050186 & 8.050323 \\
\hline Included/Excluded & 1 & 1 & 1 & 1 & 1 \\
\hline Elapsed Time & 646 & 823 & 1009 & 1193 & 1372 \\
\hline Volume (cm^3) & 30.490625 & 30.527636 & 30.533325 & 30.55702 & 30.56455 \\
\hline Volume Deviation & -0.044006 & -0.006996 & -0.001307 & 0.02239 & 0.029919 \\
\hline Density (g/cm^3) & 2.830706 & 2.827274 & 2.826747 & 2.824555 & 2.82386 \\
\hline Density Deviation & 0.004078 & 0.000646 & 0.000119 & -0.002073 & -0.002769 \\
\hline
\end{tabular}


Sample 4-2-1 (Various Carbonates):

\begin{tabular}{|l|l|l|}
\hline Version Number: & "AccuPyc 1330 V2.01 " & \\
\hline Serial Number: & 0 & \\
\hline Report Type: & Analysis & "20:26:38" \\
\hline Start Time: & $20 / 06 / 13$ & "21:08:43" \\
\hline End Time: & $20 / 06 / 13$ & \\
\hline Temperature: & 25.9162 & \\
\hline Sample ID: & $4-2-1$ & \\
\hline Sample Weight: & 73.41 & \\
\hline Number of Purges: & 10 & \\
\hline Equilibrium Rate: & 0.005 & \\
\hline Cell Volume: & 110.901 & \\
\hline Expansion Volume: & 114.296 & \\
\hline Average Volume: & 25.716 & \\
\hline $\begin{array}{l}\text { Volume Standard } \\
\text { Deviation: }\end{array}$ & 0.02237 & \\
\hline Average Density: & 2.85465 & \\
\hline $\begin{array}{l}\text { Density Standard } \\
\text { Deviation: }\end{array}$ & 0.00248 & \\
\hline Number of Runs: & 5 & \\
\hline Run Precision: & 0 & \\
\hline Percent Full: & 0.05 & \\
\hline
\end{tabular}

\begin{tabular}{|c|c|c|c|c|c|}
\hline Run Number & 1 & 2 & 3 & 4 & 5 \\
\hline $\mathrm{P} 1$ & 19.4718 & 19.4702 & 19.4067 & 19.40618 & 19.40541 \\
\hline $\mathrm{P} 2$ & 8.31675 & 8.3149 & 8.28758 & 8.286009 & 8.285308 \\
\hline Included/Excluded & 1 & 1 & 1 & 1 & 1 \\
\hline Elapsed Time & 1034 & 1421 & 1781 & 2143 & 2517 \\
\hline Volume $\left(\mathrm{cm}^{\wedge} 3\right)$ & 25.6861 & 25.7073 & 25.7104 & 25.73476 & 25.74143 \\
\hline Volume Deviation & -0.0299 & -0.0087 & -0.00561 & 0.018768 & 0.02544 \\
\hline Density (g/cm³) & 2.85797 & 2.85561 & 2.85527 & 2.852563 & 2.851823 \\
\hline Density Deviation & 0.00332 & 0.00096 & 0.00062 & -0.00208 & -0.00282 \\
\hline
\end{tabular}


Sample 4-2-2 (Various Carbonates):

\begin{tabular}{|l|l|l|}
\hline Version Number: & "AccuPyc 1330 V2.01 " & \\
\hline Serial Number: & 0 & "21:36:01" \\
\hline Report Type: & Analysis & "22:17:49" \\
\hline Start Time: & $20 / 06 / 13$ & \\
\hline End Time: & $20 / 06 / 13$ & \\
\hline Temperature: & 25.99956 & \\
\hline Sample ID: & $4-2-2$ & \\
\hline Sample Weight: & 85.62 & \\
\hline Number of Purges: & 10 & \\
\hline Equilibrium Rate: & 0.005 & \\
\hline Cell Volume: & 110.9005 & \\
\hline Expansion Volume: & 114.296 & \\
\hline Average Volume: & 30.20018 & \\
\hline $\begin{array}{l}\text { Volume Standard } \\
\text { Deviation: }\end{array}$ & 0.018175 & \\
\hline Average Density: & 2.835084 & \\
\hline $\begin{array}{l}\text { Density Standard } \\
\text { Deviation: }\end{array}$ & 0.001706 & \\
\hline Number of Runs: & 5 & \\
\hline Run Precision: & 0 & \\
\hline Percent Full: & 0.05 & \\
\hline
\end{tabular}

\begin{tabular}{|c|c|c|c|c|c|}
\hline Run Number & 1 & 2 & 3 & 4 & 5 \\
\hline $\mathrm{P} 1$ & 19.38365 & 19.3833 & 19.38422 & 19.38246 & 19.38377 \\
\hline $\mathrm{P} 2$ & 8.023232 & 8.022733 & 8.022079 & 8.020075 & 8.021702 \\
\hline Included/Excluded & 1 & 1 & 1 & 1 & 1 \\
\hline Elapsed Time & 1037 & 1409 & 1775 & 2136 & 2500 \\
\hline Volume $\left(\mathrm{cm}^{\wedge} 3\right)$ & 30.17962 & 30.18568 & 30.20347 & 30.22537 & 30.20675 \\
\hline Volume Deviation & -0.02056 & -0.01449 & 0.003294 & 0.025188 & 0.006575 \\
\hline Density $\left(\mathrm{g} / \mathrm{cm}^{\wedge} 3\right)$ & 2.837014 & 2.836444 & 2.834774 & 2.83272 & 2.834466 \\
\hline Density Deviation & 0.001931 & 0.00136 & -0.00031 & -0.00236 & -0.00062 \\
\hline
\end{tabular}


Sample 4-2-3 (Various Carbonates):

\begin{tabular}{|l|l|l|}
\hline Version Number: & "AccuPyc 1330 V2.01 " & \\
\hline Serial Number: & 0 & \\
\hline Report Type: & Analysis & "14:14:44" \\
\hline Start Time: & $14 / 04 / 13$ & "14:55:57" \\
\hline End Time: & $14 / 04 / 13$ & \\
\hline Temperature: & 27.345703 & \\
\hline Sample ID: & $4-2-3$ & \\
\hline Sample Weight: & 90.470001 & \\
\hline Number of Purges: & 10 & \\
\hline Equilibrium Rate: & 0.005 & \\
\hline Cell Volume: & 110.838661 & \\
\hline Expansion Volume: & 114.219429 & \\
\hline Average Volume: & 32.119198 & \\
\hline Volume Standard Deviation: & 0.00769 & \\
\hline Average Density: & 2.816695 & \\
\hline Density Standard Deviation: & 0.000674 & \\
\hline Number of Runs: & 5 & \\
\hline Run Precision: & 0 & \\
\hline Percent Full: & 0.05 & \\
\hline
\end{tabular}

\begin{tabular}{|c|c|c|c|c|c|}
\hline Run Number & 1 & 2 & 3 & 4 & 5 \\
\hline P1 & 19.485334 & 19.486755 & 19.483318 & 19.48376 & 19.483969 \\
\hline P2 & 7.950092 & 7.950465 & 7.950001 & 7.949211 & 7.949069 \\
\hline Included/Excluded & 1 & 1 & 1 & 1 & 1 \\
\hline Elapsed Time & 1332 & 1604 & 1897 & 2178 & 2465 \\
\hline Volume (cm^3) & 32.118603 & 32.122063 & 32.106358 & 32.12259 & 32.126385 \\
\hline Volume Deviation & -0.000595 & 0.002865 & -0.01284 & 0.003387 & 0.007187 \\
\hline Density (g/cm^3) & 2.816748 & 2.816444 & 2.817822 & 2.816399 & 2.816066 \\
\hline Density Deviation & 0.000052 & -0.000251 & 0.001126 & -0.000297 & -0.00063 \\
\hline
\end{tabular}


Sample 4-3-1 (Various Carbonates):

\begin{tabular}{|l|l|l|}
\hline Version Number: & AccuPyc 1330 V2.01 & \\
\hline Serial Number: & 0 & \\
\hline Report Type: & Analysis & "16:53:12" \\
\hline Start Time: & $22 / 04 / 13$ & "17:15:49" \\
\hline End Time: & $22 / 04 / 13$ & \\
\hline Temperature: & 26.909086 & \\
\hline Sample ID: & $4-3-1$ & \\
\hline Sample Weight: & 53.889999 & \\
\hline Number of Purges: & 10 & \\
\hline Equilibrium Rate: & 0.005 & \\
\hline Cell Volume: & 110.892372 & \\
\hline Expansion Volume: & 114.291046 & \\
\hline Average Volume: & 18.913168 & \\
\hline Volume Standard Deviation: & 0.022363 & \\
\hline Average Density: & 2.849341 & \\
\hline Density Standard Deviation: & 0.003368 & \\
\hline Number of Runs: & 5 & \\
\hline Run Precision: & 0 & \\
\hline Percent Full: & 0.05 & \\
\hline
\end{tabular}

\begin{tabular}{|c|r|r|r|r|r|}
\hline Run Number & 1 & 2 & 3 & 4 & \multicolumn{1}{l|}{5} \\
\hline P1 & 19.496517 & 19.487825 & 19.486765 & 19.49628 & 19.483648 \\
\hline P2 & 8.694674 & 8.691148 & 8.689774 & 8.692888 & 8.68649 \\
\hline Included/Excluded & 1 & 1 & 1 & 1 & 1 \\
\hline Elapsed Time & 637 & 816 & 995 & 1173 & 1349 \\
\hline Volume (cm^3) & 18.896639 & 18.889961 & 18.907181 & 18.9287 & 18.943359 \\
\hline Volume Deviation & -0.016529 & -0.023207 & -0.005987 & 0.015532 & 0.030191 \\
\hline Density (g/cm^3) & 2.85183 & 2.852838 & 2.85024 & 2.847 & 2.844796 \\
\hline Density Deviation & 0.002489 & 0.003497 & 0.000899 & -0.002341 & -0.004544 \\
\hline
\end{tabular}


Sample 4-3-2 (Various Carbonates):

\begin{tabular}{|l|l|l|}
\hline Version Number: & AccuPyc 1330 V2.01 " & \\
\hline Serial Number: & 0 & \\
\hline Report Type: & Analysis & \\
\hline Start Time: & $13 / 04 / 13$ & "11:53:39" \\
\hline End Time: & $13 / 04 / 13$ & \\
\hline Temperature: & 22.767885 & \\
\hline Sample ID: & $4-3-2$ & \\
\hline Sample Weight: & 49.389999 & \\
\hline Number of Purges: & 10 & \\
\hline Equilibrium Rate: & 0.005 & \\
\hline Cell Volume: & 110.828995 & \\
\hline Expansion Volume: & 114.17173 & \\
\hline Average Volume: & 17.435638 & \\
\hline Volume Standard Deviation: & 0.011905 & \\
\hline Average Density: & 2.832705 & \\
\hline Density Standard Deviation: & 0.001935 & \\
\hline Number of Runs: & 5 & \\
\hline Run Precision: & 0 & \\
\hline Percent Full: & 0.05 & \\
\hline
\end{tabular}

\begin{tabular}{|c|c|c|c|c|c|}
\hline Run Number & 1 & 2 & 3 & 4 & 5 \\
\hline P1 & 19.494282 & 19.49266 & 19.495848 & 19.49283 & 19.49418 \\
\hline P2 & 8.772403 & 8.770676 & 8.772051 & 8.770423 & 8.770724 \\
\hline Included/Excluded & 1 & 1 & 1 & 1 & 1 \\
\hline Elapsed Time & 802 & 961 & 1121 & 1282 & 1444 \\
\hline Volume (cm^3) & 17.416225 & 17.43551 & 17.436678 & 17.44191 & 17.44787 \\
\hline Volume Deviation & -0.019413 & -0.000132 & 0.00104 & 0.006271 & 0.012232 \\
\hline Density (g/cm^3) & 2.835861 & 2.832725 & 2.832535 & 2.831685 & 2.830718 \\
\hline Density Deviation & 0.003156 & 0.000021 & -0.00017 & -0.00102 & -0.00199 \\
\hline
\end{tabular}


Sample 4-3-3 (Various Carbonates):

\begin{tabular}{|l|l|l|}
\hline Version Number: & "AccuPyc 1330 V2.01 " & \\
\hline Serial Number: & 0 & \\
\hline Report Type: & Analysis & \\
\hline Start Time: & $13 / 04 / 13$ & "15:06:36" \\
\hline End Time: & $13 / 04 / 13$ & \\
\hline Temperature: & 25.724499 & \\
\hline Sample ID: & $4-3-3$ & \\
\hline Sample Weight: & 75.519997 & \\
\hline Number of Purges: & 10 & \\
\hline Equilibrium Rate: & 0.005 & \\
\hline Cell Volume: & 110.828995 & \\
\hline Expansion Volume: & 114.17173 & \\
\hline Average Volume: & 26.825863 & \\
\hline Volume Standard Deviation: & 0.00856 & \\
\hline Average Density: & 2.815194 & \\
\hline Density Standard Deviation: & 0.000898 & \\
\hline Number of Runs: & 5 & \\
\hline Run Precision: & 0 & \\
\hline Percent Full: & 0.05 & \\
\hline
\end{tabular}

\begin{tabular}{|c|c|c|c|c|c|}
\hline Run Number & 1 & 2 & 3 & 4 & 5 \\
\hline P1 & 19.484989 & 19.485737 & 19.490767 & 19.48894 & 19.490345 \\
\hline P2 & 8.259812 & 8.259927 & 8.262181 & 8.260646 & 8.26101 \\
\hline Included/Excluded & 1 & 1 & 1 & 1 & 1 \\
\hline Elapsed Time & 911 & 1122 & 1339 & 1552 & 1764 \\
\hline Volume (cm^3) & 26.818108 & 26.821682 & 26.819521 & 26.83296 & 26.837036 \\
\hline Volume Deviation & -0.007755 & -0.004181 & -0.006342 & 0.007101 & 0.011173 \\
\hline Density (g/cm^3) & 2.816008 & 2.815632 & 2.815859 & 2.814448 & 2.814021 \\
\hline Density Deviation & 0.000814 & 0.000438 & 0.000665 & -0.000746 & -0.001173 \\
\hline
\end{tabular}


Sample 4-4-1 (Various Carbonates):

\begin{tabular}{|l|l|l|}
\hline Version Number: & "AccuPyc 1330 V2.01 " & \\
\hline Serial Number: & 0 & \\
\hline Report Type: & Analysis & "12:56:25" \\
\hline Start Time: & $21 / 04 / 13$ & "13:19:38" \\
\hline End Time: & $21 / 04 / 13$ & \\
\hline Temperature: & 26.937973 & \\
\hline Sample ID: & $4-4-1$ & \\
\hline Sample Weight: & 37.41 & \\
\hline Number of Purges: & 10 & \\
\hline Equilibrium Rate: & 0.005 & \\
\hline Cell Volume: & 110.860016 & \\
\hline Expansion Volume: & 114.226265 & \\
\hline Average Volume: & 13.276788 & \\
\hline Volume Standard Deviation: & 0.03117 & \\
\hline Average Density: & 2.817712 & \\
\hline Density Standard Deviation: & 0.006624 & \\
\hline Number of Runs: & 5 & \\
\hline Run Precision: & 0 & \\
\hline Percent Full: & 0.05 & \\
\hline
\end{tabular}

\begin{tabular}{|c|c|c|c|c|c|}
\hline Run Number & 1 & 2 & 3 & 4 & 5 \\
\hline P1 & 19.491199 & 19.488707 & 19.491093 & 19.49112 & 19.478243 \\
\hline P2 & 8.982093 & 8.979604 & 8.978764 & 8.979081 & 8.972428 \\
\hline Included/Excluded & 1 & 1 & 1 & 1 & 1 \\
\hline Elapsed Time & 660 & 850 & 1024 & 1201 & 1385 \\
\hline Volume (cm^3) & 13.231268 & 13.258287 & 13.297371 & 13.29126 & 13.305755 \\
\hline Volume Deviation & -0.04552 & -0.0185 & 0.020583 & 0.014468 & 0.028967 \\
\hline Density (g/cm³) & 2.827393 & 2.821631 & 2.813338 & 2.814632 & 2.811565 \\
\hline Density Deviation & 0.009681 & 0.003919 & -0.004374 & -0.00308 & -0.006147 \\
\hline
\end{tabular}


Sample 4-4-2 (Various Carbonates):

\begin{tabular}{|l|l|l|}
\hline Version Number: & "AccuPyc 1330 V2.01 " & \\
\hline Serial Number: & 0 & \\
\hline Report Type: & Analysis & \\
\hline Start Time: & $13 / 04 / 13$ & "13:42:45" \\
\hline End Time: & $13 / 04 / 13$ & \\
\hline Temperature: & 24.079266 & \\
\hline Sample ID: & $4-4-2$ & \\
\hline Sample Weight: & 69.360001 & \\
\hline Number of Purges: & 10 & \\
\hline Equilibrium Rate: & 0.005 & \\
\hline Cell Volume: & 110.828995 & \\
\hline Expansion Volume: & 114.17173 & \\
\hline Average Volume: & 24.647871 & \\
\hline Volume Standard Deviation: & 0.006906 & \\
\hline Average Density: & 2.814036 & \\
\hline Density Standard Deviation: & 0.000788 & \\
\hline Number of Runs: & 5 & \\
\hline Run Precision: & 0 & \\
\hline Percent Full: & 0.05 & \\
\hline
\end{tabular}

\begin{tabular}{|c|c|c|c|c|c|}
\hline Run Number & 1 & 2 & 3 & 4 & 5 \\
\hline P1 & 19.491951 & 19.491131 & 19.494816 & 19.49382 & 19.490744 \\
\hline P2 & 8.384594 & 8.384349 & 8.385933 & 8.384953 & 8.383328 \\
\hline Included/Excluded & 1 & 1 & 1 & 1 & 1 \\
\hline Elapsed Time & 811 & 977 & 1152 & 1321 & 1491 \\
\hline Volume (cm^3) & 24.644352 & 24.642408 & 24.642429 & 24.65235 & 24.657812 \\
\hline Volume Deviation & -0.003519 & -0.005463 & -0.005442 & 0.004482 & 0.009941 \\
\hline Density (g/cm^3) & 2.814438 & 2.81466 & 2.814658 & 2.813524 & 2.812902 \\
\hline Density Deviation & 0.000402 & 0.000623 & 0.000621 & 0.000512 & -0.001135 \\
\hline
\end{tabular}


Sample 4-4-3 (Various Carbonates):

\begin{tabular}{|l|l|l|}
\hline Version Number: & "AccuPyc 1330 V2.01 " & \\
\hline Serial Number: & 0 & \\
\hline Report Type: & Analysis & "13:32:41" \\
\hline Start Time: & $13 / 06 / 13$ & "13:56:30" \\
\hline End Time: & $13 / 06 / 13$ & \\
\hline Temperature: & 25.3045 & \\
\hline Sample ID: & $4-4-3$ & \\
\hline Sample Weight: & 37.5 & \\
\hline Number of Purges: & 10 & \\
\hline Equilibrium Rate: & 0.005 & \\
\hline Cell Volume: & 110.8744 & \\
\hline Expansion Volume: & 114.2415 & \\
\hline Average Volume: & 13.1155 & \\
\hline $\begin{array}{l}\text { Volume Standard } \\
\text { Deviation: }\end{array}$ & 0.037912 & \\
\hline Average Density: & 2.859232 & \\
\hline $\begin{array}{l}\text { Density Standard } \\
\text { Deviation: }\end{array}$ & 0.008239 & \\
\hline Number of Runs: & 5 & \\
\hline Run Precision: & 0 & \\
\hline Percent Full: & 0.05 & \\
\hline
\end{tabular}

\begin{tabular}{|c|r|l|l|l|r|}
\hline Run Number & 1 & 2 & 3 & 4 & \multicolumn{1}{l|}{5} \\
\hline P1 & 19.48958 & 19.49037 & 19.48923 & 19.50024 & 19.50021 \\
\hline P2 & 8.988332 & 8.984299 & 8.987555 & 8.993504 & 8.992075 \\
\hline Included/excluded & 1 & 1 & 1 & 1 & 1 \\
\hline Elapsed time & 682 & 848 & 1032 & 1229 & 1420 \\
\hline Volume cm^3 & 13.09163 & 13.18035 & 13.10407 & 13.08647 & 13.11496 \\
\hline Volume deviation & -0.02387 & 0.064855 & -0.01143 & -0.02902 & -0.00054 \\
\hline Density g/cm^3 & 2.864426 & 2.845144 & 2.861706 & 2.865554 & 2.85933 \\
\hline Density deviation & 0.005194 & -0.01409 & 0.002474 & 0.006322 & 0.000098 \\
\hline
\end{tabular}


Sample 4-5-1 (Various Carbonates):

\begin{tabular}{|l|l|l|}
\hline Version Number: & "AccuPyc 1330 V2.01 " & \\
\hline Serial Number: & 0 & \\
\hline Report Type: & Analysis & "22:48:07" \\
\hline Start Time: & $20 / 06 / 13$ & "23:17:49" \\
\hline End Time: & $20 / 06 / 13$ & \\
\hline Temperature: & 26.06295 & \\
\hline Sample ID: & $4-5-1$ & \\
\hline Sample Weight: & 62.12 & \\
\hline Number of Purges: & 10 & \\
\hline Equilibrium Rate: & 0.005 & \\
\hline Cell Volume: & 110.9005 & \\
\hline Expansion Volume: & 114.296 & \\
\hline Average Volume: & 21.69024 & \\
\hline $\begin{array}{l}\text { Volume Standard } \\
\text { Deviation: }\end{array}$ & 0.018731 & \\
\hline Average Density: & 2.863963 & \\
\hline $\begin{array}{l}\text { Density Standard } \\
\text { Deviation: }\end{array}$ & 0.002474 & \\
\hline Number of Runs: & 5 & \\
\hline Run Precision: & 0 & \\
\hline Percent Full: & 0.05 & \\
\hline
\end{tabular}

\begin{tabular}{|c|r|r|r|r|r|}
\hline Run Number & 1 & 2 & 3 & 4 & \multicolumn{1}{l|}{5} \\
\hline P1 & 19.50543 & 19.50713 & 19.50254 & 19.5011 & 19.5025 \\
\hline P2 & 8.055882 & 8.054405 & 8.052176 & 8.050186 & 8.050323 \\
\hline Included/Excluded & 1 & 1 & 1 & 1 & 1 \\
\hline Elapsed Time & 646 & 823 & 1009 & 1193 & 1372 \\
\hline Volume (cm^3) & 30.49063 & 30.52764 & 30.53333 & 30.55702 & 30.56455 \\
\hline Volume Deviation & -0.04401 & -0.007 & -0.00131 & 0.02239 & 0.029919 \\
\hline Density (g/cm^3) & 2.830706 & 2.827274 & 2.826747 & 2.824555 & 2.82386 \\
\hline Density Deviation & 0.004078 & 0.000646 & 0.000119 & -0.00207 & -0.00277 \\
\hline
\end{tabular}


Sample 5-1-1 (Water Cooled Slag):

\begin{tabular}{|l|l|l|}
\hline Version Number: & "AccuPyc 1330 V2.01 " & \\
\hline Serial Number: & 0 & \\
\hline Report Type: & Analysis & "09:46:57" \\
\hline Start Time: & $23 / 04 / 13$ & "10:20:27" \\
\hline End Time: & $23 / 04 / 13$ & \\
\hline Temperature: & 26.633774 & \\
\hline Sample ID: & $5-1-1$ & \\
\hline Sample Weight: & 71.360001 & \\
\hline Number of Purges: & 10 & \\
\hline Equilibrium Rate: & 0.005 & \\
\hline Cell Volume: & 110.890297 & \\
\hline Expansion Volume: & 114.27034 & \\
\hline Average Volume: & 24.337467 & \\
\hline Volume Standard Deviation: & 0.009181 & \\
\hline Average Density: & 2.932105 & \\
\hline Density Standard Deviation: & 0.001106 & \\
\hline Number of Runs: & 5 & \\
\hline Run Precision: & 0 & \\
\hline Percent Full: & 0.05 & \\
\hline
\end{tabular}

\begin{tabular}{|c|c|c|c|c|c|}
\hline Run Number & 1 & 2 & 3 & 4 & 5 \\
\hline P1 & 19.447256 & 19.438597 & 19.436113 & 19.44235 & 19.446646 \\
\hline P2 & 8.38168 & 8.378663 & 8.376519 & 8.378962 & 8.381156 \\
\hline Included/Excluded & 1 & 1 & 1 & 1 & 1 \\
\hline Elapsed Time & 829 & 1125 & 1414 & 1696 & 2002 \\
\hline Volume $\left(\mathrm{cm}^{\wedge} 3\right)$ & 24.335623 & 24.322628 & 24.342121 & 24.34661 & 24.340351 \\
\hline Volume Deviation & -0.001844 & -0.014839 & 0.004654 & 0.009144 & 0.002884 \\
\hline Density (g/cm^3) & 2.932327 & 2.933893 & 2.931544 & 2.931004 & 2.931757 \\
\hline Density Deviation & 0.000222 & 0.001788 & -0.000561 & -0.001101 & -0.000348 \\
\hline
\end{tabular}


Sample 5-1-2 (Water Cooled Slag):

\begin{tabular}{|l|l|l|}
\hline Version Number: & "AccuPyc 1330 V2.01 " & \\
\hline Serial Number: & 0 & \\
\hline Report Type: & Analysis & \\
\hline Start Time: & $23 / 04 / 13$ & "10:25:30" \\
\hline End Time: & $23 / 04 / 13$ & \\
\hline Temperature: & 26.634541 & \\
\hline Sample ID: & $5-1-2$ & \\
\hline Sample Weight: & 84.25 & \\
\hline Number of Purges: & 10 & \\
\hline Equilibrium Rate: & 0.005 & \\
\hline Cell Volume: & 110.890297 & \\
\hline Expansion Volume: & 114.27034 & \\
\hline Average Volume: & 28.436399 & \\
\hline Volume Standard Deviation: & 0.030683 & \\
\hline Average Density: & 2.962755 & \\
\hline Density Standard Deviation: & 0.003199 & \\
\hline Number of Runs: & 5 & \\
\hline Run Precision: & 0 & \\
\hline Percent Full: & 0.05 & \\
\hline
\end{tabular}

\begin{tabular}{|c|c|c|c|c|c|}
\hline Run Number & 1 & 2 & 3 & 4 & 5 \\
\hline P1 & 19.466621 & 19.465544 & 19.473581 & 19.47316 & 19.472363 \\
\hline P2 & 8.139959 & 8.135403 & 8.138261 & 8.136418 & 8.136798 \\
\hline Included/Excluded & 1 & 1 & 1 & 1 & 1 \\
\hline Elapsed Time & 644 & 827 & 1018 & 1205 & 1400 \\
\hline Volume (cm^3) & 28.769377 & 28.840548 & 28.849226 & 28.87811 & 28.86574 \\
\hline Volume Deviation & -0.071222 & -0.000051 & 0.008627 & 0.03751 & 0.025141 \\
\hline Density (g/cm^3) & 2.935413 & 2.928169 & 2.927288 & 2.924361 & 2.925613 \\
\hline Density Deviation & 0.007244 & 0 & -0.000881 & -0.003808 & -0.002555 \\
\hline
\end{tabular}


Sample 5-1-3 (Water Cooled Slag):

\begin{tabular}{|l|l|l|}
\hline Version Number: & "AccuPyc 1330 V2.01 " & \\
\hline Serial Number: & 0 & \\
\hline Report Type: & Analysis & "14:31:56" \\
\hline Start Time: & $13 / 04 / 13$ & \\
\hline End Time: & $13 / 04 / 13$ & \\
\hline Temperature: & 25.439217 & \\
\hline Sample ID: & $5-1-3$ & \\
\hline Sample Weight: & 68.75 & \\
\hline Number of Purges: & 10 & \\
\hline Equilibrium Rate: & 0.005 & \\
\hline Cell Volume: & 110.828995 & \\
\hline Expansion Volume: & 114.17173 & \\
\hline Average Volume: & 23.301971 & \\
\hline Volume Standard Deviation: & 0.021638 & \\
\hline Average Density: & 2.950396 & \\
\hline Density Standard Deviation: & 0.002741 & \\
\hline Number of Runs: & 5 & \\
\hline Run Precision: & 0 & \\
\hline Percent Full: & 0.05 & \\
\hline
\end{tabular}

\begin{tabular}{|c|c|c|c|c|c|}
\hline Run Number & 1 & 2 & 3 & 4 & 5 \\
\hline P1 & 19.490837 & 19.497063 & 19.491199 & 19.49495 & 19.498863 \\
\hline P2 & 8.459823 & 8.460071 & 8.458391 & 8.458434 & 8.461578 \\
\hline Included/Excluded & 1 & 1 & 1 & 1 & 1 \\
\hline Elapsed Time & 827 & 992 & 1176 & 1344 & 1523 \\
\hline Volume $\left(\mathrm{cm}^{\wedge} 3\right)$ & 23.26927 & 23.314127 & 23.298321 & 23.32729 & 23.300852 \\
\hline Volume Deviation & -0.032701 & 0.012156 & -0.003651 & 0.02532 & -0.00112 \\
\hline Density (g/cm^3) & 2.95454 & 2.948856 & 2.950856 & 2.947192 & 2.950536 \\
\hline Density Deviation & 0.004144 & -0.00154 & 0.00046 & -0.003204 & 0.00014 \\
\hline
\end{tabular}


Sample 5-1-4 (Water Cooled Slag):

\begin{tabular}{|l|l|l|}
\hline Version Number: & AccuPyc 1330 V2.01 & \\
\hline Serial Number: & 0 & \\
\hline Report Type: & Analysis & \\
\hline Start Time: & $23 / 04 / 13$ & "09:18:41" \\
\hline End Time: & $23 / 04 / 13$ & \\
\hline Temperature: & 26.657036 & \\
\hline Sample ID: & $5-1-4$ & \\
\hline Sample Weight: & 70.269997 & \\
\hline Number of Purges: & 10 & \\
\hline Equilibrium Rate: & 0.005 & \\
\hline Cell Volume: & 110.890297 & \\
\hline Expansion Volume: & 114.27034 & \\
\hline Average Volume: & 23.76989 & \\
\hline Volume Standard Deviation: & 0.020343 & \\
\hline Average Density: & 2.956263 & \\
\hline Density Standard Deviation: & 0.002531 & \\
\hline Number of Runs: & 5 & \\
\hline Run Precision: & 0 & \\
\hline Percent Full: & 0.05 & \\
\hline
\end{tabular}

\begin{tabular}{|c|c|c|c|c|c|}
\hline Run Number & 1 & 2 & 3 & 4 & 5 \\
\hline P1 & 19.476768 & 19.48231 & 19.482685 & 19.48305 & 19.48307 \\
\hline P2 & 8.42642 & 8.429402 & 8.427493 & 8.427597 & 8.427139 \\
\hline Included/Excluded & 1 & 1 & 1 & 1 & 1 \\
\hline Elapsed Time & 662 & 867 & 1061 & 1258 & 1453 \\
\hline Volume (cm^3) & 23.753685 & 23.74304 & 23.780773 & 23.78172 & 23.79022 \\
\hline Volume Deviation & -0.016205 & -0.026848 & 0.010883 & 0.011831 & 0.020334 \\
\hline Density (g/cm^3) & 2.958278 & 2.959604 & 2.954908 & 2.95479 & 2.953734 \\
\hline Density Deviation & 0.002015 & 0.003341 & -0.001355 & -0.00147 & -0.00253 \\
\hline
\end{tabular}


Sample 5-1-5 (Water Cooled Slag):

\begin{tabular}{|l|l|l|}
\hline Version Number: & AccuPyc 1330 V2.01 & \\
\hline Serial Number: & 0 & \\
\hline Report Type: & Analysis & \\
\hline Start Time: & $23 / 04 / 13$ & "08:51:03" \\
\hline End Time: & $23 / 04 / 13$ & \\
\hline Temperature: & 26.66445 & \\
\hline Sample ID: & $5-1-5$ & \\
\hline Sample Weight: & 83.800003 & \\
\hline Number of Purges: & 10 & \\
\hline Equilibrium Rate: & 0.005 & \\
\hline Cell Volume: & 110.890297 & \\
\hline Expansion Volume: & 114.27034 & \\
\hline Average Volume: & 28.250586 & \\
\hline Volume Standard Deviation: & 0.042513 & \\
\hline Average Density: & 2.966316 & \\
\hline Density Standard Deviation: & 0.004464 & \\
\hline Number of Runs: & 5 & \\
\hline Run Precision: & 0 & \\
\hline Percent Full: & 0.05 & \\
\hline
\end{tabular}

\begin{tabular}{|c|c|c|c|c|c|}
\hline Run Number & 1 & 2 & 3 & 4 & 5 \\
\hline P1 & 19.481804 & 19.487535 & 19.481077 & 19.48119 & 19.481167 \\
\hline P2 & 8.179303 & 8.180055 & 8.174441 & 8.175867 & 8.172772 \\
\hline Included/Excluded & 1 & 1 & 1 & 1 & 1 \\
\hline Elapsed Time & 615 & 798 & 969 & 1145 & 1306 \\
\hline Volume (cm^3) & 28.196053 & 28.224878 & 28.275433 & 28.25143 & 28.305143 \\
\hline Volume Deviation & -0.054533 & -0.025707 & 0.024847 & 0.000839 & 0.054558 \\
\hline Density (g/cm^3) & 2.972047 & 2.969012 & 2.963704 & 2.966222 & 2.960593 \\
\hline Density Deviation & 0.005732 & 0.002697 & -0.002612 & -0.000093 & -0.005723 \\
\hline
\end{tabular}


Sample 5-2-1 (Water Cooled Slag):

\begin{tabular}{|l|l|l|}
\hline Version Number: & "AccuPyc 1330 V2.01 " & \\
\hline Serial Number: & 0 & \\
\hline Report Type: & Analysis & "17:18:12" \\
\hline Start Time: & $22 / 04 / 13$ & \\
\hline End Time: & $22 / 04 / 13$ & \\
\hline Temperature: & 27.024887 & \\
\hline Sample ID: & $5-2-1$ & \\
\hline Sample Weight: & 78.019997 & \\
\hline Number of Purges: & 10 & \\
\hline Equilibrium Rate: & 0.005 & \\
\hline Cell Volume: & 110.892372 & \\
\hline Expansion Volume: & 114.291046 & \\
\hline Average Volume: & 26.232475 & \\
\hline Volume Standard Deviation: & 0.033729 & \\
\hline Average Density: & 2.97418 & \\
\hline Density Standard Deviation: & 0.003823 & \\
\hline Number of Runs: & 5 & \\
\hline Run Precision: & 0 & \\
\hline Percent Full: & 0.05 & \\
\hline
\end{tabular}

\begin{tabular}{|c|c|c|c|c|c|}
\hline Run Number & 1 & 2 & 3 & 4 & 5 \\
\hline P1 & 19.483879 & 19.484093 & 19.492355 & 19.491619 & 19.47881 \\
\hline P2 & 8.293203 & 8.292408 & 8.294724 & 8.29328 & 8.286242 \\
\hline Included/Excluded & 1 & 1 & 1 & 1 & 1 \\
\hline Elapsed Time & 678 & 868 & 1058 & 1246 & 1431 \\
\hline Volume $\left(\mathrm{cm}^{\wedge} 3\right)$ & 26.193386 & 26.209145 & 26.230469 & 26.250572 & 26.27881 \\
\hline Volume Deviation & -0.039089 & -0.023331 & -0.002007 & 0.018097 & 0.046333 \\
\hline Density (g/cm^3) & 2.978614 & 2.976824 & 2.974403 & 2.972126 & 2.968932 \\
\hline Density Deviation & 0.004435 & 0.002644 & 0.000224 & -0.002054 & -0.005248 \\
\hline
\end{tabular}


Sample 5-2-2 (Water Cooled Slag):

\begin{tabular}{|l|l|l|}
\hline Version Number: & AccuPyc 1330 V2.01 & \\
\hline Serial Number: & 0 & \\
\hline Report Type: & Analysis & \\
\hline Start Time: & $23 / 04 / 13$ & "13:11:59" \\
\hline End Time: & $23 / 04 / 13$ & \\
\hline Temperature: & 26.478096 & \\
\hline Sample ID: & $5-2-2$ & \\
\hline Sample Weight: & 95.32 & \\
\hline Number of Purges: & 10 & \\
\hline Equilibrium Rate: & 0.005 & \\
\hline Cell Volume: & 110.890297 & \\
\hline Expansion Volume: & 114.27034 & \\
\hline Average Volume: & 32.664051 & \\
\hline Volume Standard Deviation: & 0.039519 & \\
\hline Average Density: & 2.918196 & \\
\hline Density Standard Deviation: & 0.003525 & \\
\hline Number of Runs: & 5 & \\
\hline Run Precision: & 0 & \\
\hline Percent Full: & 0.05 & \\
\hline
\end{tabular}

\begin{tabular}{|c|c|c|c|c|c|}
\hline Run Number & 1 & 2 & 3 & 4 & 5 \\
\hline P1 & 19.459475 & 19.444866 & 19.442474 & 19.47152 & 19.47344 \\
\hline P2 & 7.90371 & 7.903575 & 7.901884 & 7.913949 & 7.914047 \\
\hline Included/Excluded & 1 & 1 & 1 & 1 & 1 \\
\hline Elapsed Time & 672 & 886 & 1095 & 1307 & 1521 \\
\hline Volume (cm^3) & 32.733658 & 32.636982 & 32.648979 & 32.64462 & 32.65601 \\
\hline Volume Deviation & 0.069607 & -0.027069 & -0.015072 & -0.019428 & -0.008041 \\
\hline Density (g/cm^3) & 2.911987 & 2.920613 & 2.91954 & 2.91993 & 2.918911 \\
\hline Density Deviation & -0.006209 & 0.002417 & 0.001344 & 0.001733 & 0.000715 \\
\hline
\end{tabular}


Sample 5-2-3 (Water Cooled Slag):

\begin{tabular}{|l|l|l|}
\hline Version Number: & AccuPyc 1330 V2.01 & \\
\hline Serial Number: & 0 & \\
\hline Report Type: & Analysis & "12:43:51" \\
\hline Start Time: & $23 / 04 / 13$ & "13:07:19" \\
\hline End Time: & $23 / 04 / 13$ & \\
\hline Temperature: & 26.531523 & \\
\hline Sample ID: & $5-2-3$ & \\
\hline Sample Weight: & 84.449997 & \\
\hline Number of Purges: & 10 & \\
\hline Equilibrium Rate: & 0.005 & \\
\hline Cell Volume: & 110.890297 & \\
\hline Expansion Volume: & 114.27034 & \\
\hline Average Volume: & 28.840599 & \\
\hline Volume Standard Deviation: & 0.042385 & \\
\hline Average Density: & 2.928169 & \\
\hline Density Standard Deviation: & 0.004309 & \\
\hline Number of Runs: & 5 & \\
\hline Run Precision: & 0 & \\
\hline Percent Full: & 0.05 & \\
\hline
\end{tabular}

\begin{tabular}{|c|c|c|c|c|c|}
\hline Run Number & 1 & 2 & 3 & 4 & 5 \\
\hline P1 & 19.466621 & 19.465544 & 19.473581 & 19.47316 & 19.472363 \\
\hline P2 & 8.139959 & 8.135403 & 8.138261 & 8.136418 & 8.136798 \\
\hline Included/Excluded & 1 & 1 & 1 & 1 & 1 \\
\hline Elapsed Time & 644 & 827 & 1018 & 1205 & 1400 \\
\hline Volume (cm^3) & 28.769377 & 28.840548 & 28.849226 & 28.87811 & 28.86574 \\
\hline Volume Deviation & -0.071222 & -0.000051 & 0.008627 & 0.03751 & 0.025141 \\
\hline Density (g/cm^3) & 2.935413 & 2.928169 & 2.927288 & 2.924361 & 2.925613 \\
\hline Density Deviation & 0.007244 & 0 & -0.000881 & -0.003808 & -0.002555 \\
\hline
\end{tabular}


Sample 5-2-5 (Water Cooled Slag):

\begin{tabular}{|l|l|l|}
\hline Version Number: & AccuPyc 1330 V2.01 & \\
\hline Serial Number: & 0 & \\
\hline Report Type: & Analysis & \\
\hline Start Time: & $23 / 04 / 13$ & "14:43:04" \\
\hline End Time: & $23 / 04 / 13$ & \\
\hline Temperature: & 26.503147 & \\
\hline Sample ID: & $5-2-5$ & \\
\hline Sample Weight: & 85.660004 & \\
\hline Number of Purges: & 10 & \\
\hline Equilibrium Rate: & 0.005 & \\
\hline Cell Volume: & 110.890297 & \\
\hline Expansion Volume: & 114.27034 & \\
\hline Average Volume: & 29.191715 & \\
\hline Volume Standard Deviation: & 0.371293 & \\
\hline Average Density: & 2.934768 & \\
\hline Density Standard Deviation: & 0.036709 & \\
\hline Number of Runs: & 5 & \\
\hline Run Precision: & 0 & \\
\hline Percent Full: & 0.05 & \\
\hline
\end{tabular}

\begin{tabular}{|c|c|c|c|c|c|}
\hline Run Number & 1 & 2 & 3 & 4 & 5 \\
\hline P1 & 19.373899 & 19.349257 & 19.344917 & 19.34263 & 19.379606 \\
\hline P2 & 8.086795 & 8.077781 & 8.074727 & 8.025593 & 8.086432 \\
\hline Included/Excluded & 1 & 1 & 1 & 1 & 1 \\
\hline Elapsed Time & 1291 & 1707 & 2149 & 2509 & 2971 \\
\hline Volume (cm^3) & 29.019806 & 28.997671 & 29.019291 & 29.85433 & 29.067472 \\
\hline Volume Deviation & -0.171909 & -0.194044 & -0.172424 & 0.662617 & -0.124243 \\
\hline Density (g/cm^3) & 2.951777 & 2.954031 & 2.95183 & 2.869266 & 2.946937 \\
\hline Density Deviation & 0.017009 & 0.019263 & 0.017062 & -0.065502 & 0.012169 \\
\hline
\end{tabular}


Sample 5-3-1(Water Cooled Slag):

\begin{tabular}{|l|l|l|}
\hline Version Number: & "AccuPyc 1330 V2.01 " & \\
\hline Serial Number: & 0 & \\
\hline Report Type: & Analysis & "23:28:32" \\
\hline Start Time: & $20 / 06 / 13$ & "00:16:27" \\
\hline End Time: & $21 / 06 / 13$ & \\
\hline Temperature: & 26.1322 & \\
\hline Sample ID: & $5-3-1$ & \\
\hline Sample Weight: & 93.68 & \\
\hline Number of Purges: & 10 & \\
\hline Equilibrium Rate: & 0.005 & \\
\hline Cell Volume: & 110.901 & \\
\hline Expansion Volume: & 114.296 & \\
\hline Average Volume: & 31.7292 & \\
\hline Volume Standard Deviation: & 0.03231 & \\
\hline Average Density: & 2.95249 & \\
\hline Density Standard Deviation: & 0.00301 & \\
\hline Number of Runs: & 5 & \\
\hline Run Precision: & 0 & \\
\hline Percent Full: & 0.05 & \\
\hline
\end{tabular}

\begin{tabular}{|c|c|c|c|c|c|}
\hline Run Number & 1 & 2 & 3 & 4 & 5 \\
\hline $\mathrm{P} 1$ & 19.3719 & 19.3909 & 19.374 & 19.3985 & 19.3707 \\
\hline $\mathrm{P} 2$ & 7.92969 & 7.93682 & 7.92742 & 7.93776 & 7.92453 \\
\hline Included/Excluded & 1 & 1 & 1 & 1 & 1 \\
\hline Elapsed Time & 1125 & 1567 & 1985 & 2409 & 2867 \\
\hline Volume (cm^3) & 31.6911 & 31.7019 & 31.7442 & 31.7388 & 31.77 \\
\hline Volume Deviation & -0.03807 & 0.02729 & 0.01495 & 0.00959 & 0.04083 \\
\hline Density (g/cm³) & 2.95603 & 2.95503 & 2.9511 & 2.95159 & 2.94869 \\
\hline & & & & - & \\
Density Deviation & 0.00354 & 0.00254 & -0.00139 & 0.00089 & -0.0038 \\
\hline
\end{tabular}


Sample 5-3-3 (Water Cooled Slag):

\begin{tabular}{|l|l|l|}
\hline Version Number: & "AccuPyc 1330 V2.01 " & \\
\hline Serial Number: & 0 & \\
\hline Report Type: & Analysis & \\
\hline Start Time: & $14 / 04 / 13$ & "13:37:06" \\
\hline End Time: & $14 / 04 / 13$ & \\
\hline Temperature: & 27.099276 & \\
\hline Sample ID: & $5-3-3$ & \\
\hline Sample Weight: & 80.800003 & \\
\hline Number of Purges: & 10 & \\
\hline Equilibrium Rate: & 0.005 & \\
\hline Cell Volume: & 110.838661 & \\
\hline Expansion Volume: & 114.219429 & \\
\hline Average Volume: & 27.338009 & \\
\hline Volume Standard Deviation: & 0.015871 & \\
\hline Average Density: & 2.955593 & \\
\hline Density Standard Deviation: & 0.001716 & \\
\hline Number of Runs: & 5 & \\
\hline Run Precision: & 0 & \\
\hline Percent Full: & 0.05 & \\
\hline
\end{tabular}

\begin{tabular}{|c|c|c|c|c|c|}
\hline Run Number & 1 & 2 & 3 & 4 & 5 \\
\hline P1 & 19.483969 & 19.483814 & 19.485714 & 19.48411 & 19.483557 \\
\hline P2 & 8.22737 & 8.228358 & 8.228774 & 8.229899 & 8.228261 \\
\hline Included/Excluded & 1 & 1 & 1 & 1 & 1 \\
\hline Elapsed Time & 1293 & 1568 & 1855 & 2137 & 2428 \\
\hline Volume (cm^3) & 27.356468 & 27.337967 & 27.344755 & 27.31309 & 27.337767 \\
\hline Volume Deviation & 0.018459 & -0.000042 & 0.006746 & -0.024923 & -0.000242 \\
\hline Density (g/cm^3) & 2.953598 & 2.955597 & 2.954863 & 2.958289 & 2.955618 \\
\hline Density Deviation & -0.001995 & 0.000004 & -0.00073 & 0.002696 & 0.000026 \\
\hline
\end{tabular}


Sample 6-1-1 (Jacobsville Sandstone):

\begin{tabular}{|l|l|l|}
\hline Version Number: & "AccuPyc 1330 V2.01 " & \\
\hline Serial Number: & 0 & \\
\hline Report Type: & Analysis & "11:03:04" \\
\hline Start Time: & $12 / 06 / 13$ & "11:21:31" \\
\hline End Time: & $12 / 06 / 13$ & \\
\hline Temperature: & 24.26613 & \\
\hline Sample ID: & $6-1-1$ & \\
\hline Sample Weight: & 83.75 & \\
\hline Number of Purges: & 10 & \\
\hline Equilibrium Rate: & 0.005 & \\
\hline Cell Volume: & 110.945335 & \\
\hline Expansion Volume: & 114.36113 & \\
\hline Average Volume: & 31.547991 & \\
\hline Volume Standard Deviation: & 0.008871 & \\
\hline Average Density: & 2.654686 & \\
\hline Density Standard Deviation: & 0.000747 & \\
\hline Number of Runs: & 5 & \\
\hline Run Precision: & 0 & \\
\hline Percent Full: & 0.05 & \\
\hline
\end{tabular}

\begin{tabular}{|c|c|c|c|c|c|}
\hline Run Number & 1 & 2 & 3 & 4 & 5 \\
\hline P1 & 19.517822 & 19.517786 & 19.527264 & 19.51695 & 19.492661 \\
\hline P2 & 7.998646 & 7.998198 & 8.00118 & 7.997218 & 7.987506 \\
\hline Included/Excluded & 1 & 1 & 1 & 1 & 1 \\
\hline Elapsed Time & 540 & 677 & 814 & 963 & 1099 \\
\hline Volume (cm^3) & 31.53565 & 31.54294 & 31.5581 & 31.55367 & 31.549593 \\
\hline Volume Deviation & -0.012341 & -0.005051 & 0.010109 & 0.005678 & 0.001602 \\
\hline Density (g/cm^3) & 2.655725 & 2.655111 & 2.653835 & 2.654208 & 2.654551 \\
\hline Density Deviation & 0.001039 & 0.000425 & -0.00085 & -0.000478 & -0.000135 \\
\hline
\end{tabular}


Sample 6-1-2 (Jacobsville Sandstone):

\begin{tabular}{|l|l|l|}
\hline Version Number: & "AccuPyc 1330 V2.01 " & \\
\hline Serial Number: & 0 & \\
\hline Report Type: & Analysis & \\
\hline Start Time: & $12 / 06 / 13$ & "11:54:43" $05 "$ \\
\hline End Time: & $12 / 06 / 13$ & \\
\hline Temperature: & 24.502077 & \\
\hline Sample ID: & $6-1-2$ & \\
\hline Sample Weight: & 84.910004 & \\
\hline Number of Purges: & 10 & \\
\hline Equilibrium Rate: & 0.005 & \\
\hline Cell Volume: & 110.945335 & \\
\hline Expansion Volume: & 114.36113 & \\
\hline Average Volume: & 32.078056 & \\
\hline Volume Standard Deviation: & 0.013747 & \\
\hline Average Density: & 2.646981 & \\
\hline Density Standard Deviation: & 0.001135 & \\
\hline Number of Runs: & 5 & \\
\hline Run Precision: & 0 & \\
\hline Percent Full: & 0.05 & \\
\hline
\end{tabular}

\begin{tabular}{|c|c|c|c|c|c|}
\hline Run Number & 1 & 2 & 3 & 4 & 5 \\
\hline P1 & 19.502987 & 19.500544 & 19.50061 & 19.50087 & 19.500246 \\
\hline P2 & 7.961615 & 7.959416 & 7.958828 & 7.958702 & 7.958767 \\
\hline Included/Excluded & 1 & 1 & 1 & 1 & 1 \\
\hline Elapsed Time & 571 & 704 & 836 & 966 & 1094 \\
\hline Volume (cm^3) & 32.055294 & 32.075409 & 32.085716 & 32.08962 & 32.084248 \\
\hline Volume Deviation & -0.022762 & -0.002647 & 0.00766 & 0.011566 & 0.006191 \\
\hline Density (g/cm^3) & 2.64886 & 2.647199 & 2.646349 & 2.646027 & 2.64647 \\
\hline Density Deviation & 0.001879 & 0.000218 & -0.000632 & -0.000954 & -0.000511 \\
\hline
\end{tabular}


Sample 6-1-3 (Jacobsville Sandstone):

\begin{tabular}{|l|l|l|}
\hline Version Number: & "AccuPyc 1330 V2.01 " & \\
\hline Serial Number: & 0 & \\
\hline Report Type: & Analysis & "12:16:59" \\
\hline Start Time: & $12 / 06 / 13$ & "12:37:10" \\
\hline End Time: & $12 / 06 / 13$ & \\
\hline Temperature: & 24.863794 & \\
\hline Sample ID: & $6-1-3$ & \\
\hline Sample Weight: & 76.959999 & \\
\hline Number of Purges: & 10 & \\
\hline Equilibrium Rate: & 0.005 & \\
\hline Cell Volume: & 110.945335 & \\
\hline Expansion Volume: & 114.36113 & \\
\hline Average Volume: & 28.982569 & \\
\hline Volume Standard Deviation: & 0.029633 & \\
\hline Average Density: & 2.655391 & \\
\hline Density Standard Deviation: & 0.002716 & \\
\hline Number of Runs: & 5 & \\
\hline Run Precision: & 0 & \\
\hline Percent Full: & 0.05 & \\
\hline
\end{tabular}

\begin{tabular}{|c|c|c|c|c|c|}
\hline Run Number & 1 & 2 & 3 & 4 & 5 \\
\hline P1 & 19.51033 & 19.506876 & 19.507483 & 19.50594 & 19.505447 \\
\hline P2 & 8.147813 & 8.144702 & 8.143117 & 8.141564 & 8.142892 \\
\hline Included/Excluded & 1 & 1 & 1 & 1 & 1 \\
\hline Elapsed Time & 644 & 786 & 925 & 1063 & 1203 \\
\hline Volume (cm^3) & 28.939468 & 28.968302 & 29.000061 & 29.01574 & 28.989273 \\
\hline Volume Deviation & -0.0431 & -0.014267 & 0.017492 & 0.033171 & 0.006704 \\
\hline Density (g/cm^3) & 2.659344 & 2.656697 & 2.653787 & 2.652354 & 2.654775 \\
\hline Density Deviation & 0.003953 & 0.001305 & -0.001604 & -0.003038 & -0.000616 \\
\hline
\end{tabular}


Sample 6-1-4 (Jacobsville Sandstone):

\begin{tabular}{|l|l|l|}
\hline Version Number: & "AccuPyc 1330 V2.01 " & \\
\hline Serial Number: & 0 & \\
\hline Report Type: & Analysis & "12:39:52" \\
\hline Start Time: & $12 / 06 / 13$ & "13:00:43" \\
\hline End Time: & $12 / 06 / 13$ & \\
\hline Temperature: & 25.018705 & \\
\hline Sample ID: & $6-1-4$ & \\
\hline Sample Weight: & 73.230003 & \\
\hline Number of Purges: & 10 & \\
\hline Equilibrium Rate: & 0.005 & \\
\hline Cell Volume: & 110.945335 & \\
\hline Expansion Volume: & 114.36113 & \\
\hline Average Volume: & 27.596916 & \\
\hline Volume Standard Deviation: & 0.012219 & \\
\hline Average Density: & 2.653558 & \\
\hline Density Standard Deviation: & 0.001175 & \\
\hline Number of Runs: & 5 & \\
\hline Run Precision: & 0 & \\
\hline Percent Full: & 0.05 & \\
\hline
\end{tabular}

\begin{tabular}{|c|c|c|c|c|c|}
\hline Run Number & 1 & 2 & 3 & 4 & 5 \\
\hline P1 & 19.500359 & 19.518183 & 19.494411 & 19.52564 & 19.525551 \\
\hline P2 & 8.221876 & 8.228382 & 8.21818 & 8.230689 & 8.230989 \\
\hline Included/Excluded & 1 & 1 & 1 & 1 & 1 \\
\hline Elapsed Time & 663 & 810 & 954 & 1095 & 1243 \\
\hline Volume (cm^3) & 27.577467 & 27.59514 & 27.598316 & 27.60978 & 27.603874 \\
\hline Volume Deviation & -0.019449 & -0.001776 & 0.0014 & 0.012863 & 0.006958 \\
\hline Density (g/cm^3) & 2.655429 & 2.653728 & 2.653423 & 2.652321 & 2.652889 \\
\hline Density Deviation & 0.001871 & 0.00017 & -0.000135 & -0.001237 & -0.000669 \\
\hline
\end{tabular}


Sample 6-1-5 (Jacobsville Sandstone):

\begin{tabular}{|l|l|l|}
\hline Version Number: & "AccuPyc 1330 V2.01 " & \\
\hline Serial Number: & 0 & \\
\hline Report Type: & Analysis & \\
\hline Start Time: & $12 / 06 / 13$ & "13:06:58" \\
\hline End Time: & $12 / 06 / 13$ & \\
\hline Temperature: & 25.219118 & \\
\hline Sample ID: & $6-1-5$ & \\
\hline Sample Weight: & 73.739998 & \\
\hline Number of Purges: & 10 & \\
\hline Equilibrium Rate: & 0.005 & \\
\hline Cell Volume: & 110.945335 & \\
\hline Expansion Volume: & 114.36113 & \\
\hline Average Volume: & 27.776466 & \\
\hline Volume Standard Deviation: & 0.0131 & \\
\hline Average Density: & 2.654766 & \\
\hline Density Standard Deviation: & 0.001252 & \\
\hline Number of Runs: & 5 & \\
\hline Run Precision: & 0 & \\
\hline Percent Full: & 0.05 & \\
\hline
\end{tabular}

\begin{tabular}{|c|c|c|c|c|c|}
\hline Run Number & 1 & 2 & 3 & 4 & 5 \\
\hline P1 & 19.500635 & 19.495426 & 19.495785 & 19.49434 & 19.494036 \\
\hline P2 & 8.211864 & 8.208285 & 8.208385 & 8.207908 & 8.207045 \\
\hline Included/Excluded & 1 & 1 & 1 & 1 & 1 \\
\hline Elapsed Time & 688 & 823 & 955 & 1092 & 1228 \\
\hline Volume (cm^3) & 27.754885 & 27.779119 & 27.78001 & 27.77773 & 27.790588 \\
\hline Volume Deviation & -0.021582 & 0.002653 & 0.003544 & 0.001266 & 0.014122 \\
\hline Density (g/cm^3) & 2.656829 & 2.654512 & 2.654427 & 2.654644 & 2.653416 \\
\hline Density Deviation & 0.002064 & -0.000254 & -0.000339 & -0.000121 & -0.001349 \\
\hline
\end{tabular}


Sample 6-1-6 (Jacobsville Sandstone):

\begin{tabular}{|l|l|l|}
\hline Version Number: & "AccuPyc 1330 V2.01 " & \\
\hline Serial Number: & 0 & \\
\hline Report Type: & Analysis & "13:43:45" \\
\hline Start Time: & $12 / 06 / 13$ & \\
\hline End Time: & $12 / 06 / 13$ & \\
\hline Temperature: & 25.456087 & \\
\hline Sample ID: & $6-1-6$ & \\
\hline Sample Weight: & 73.489998 & \\
\hline Number of Purges: & 10 & \\
\hline Equilibrium Rate: & 0.005 & \\
\hline Cell Volume: & 110.945335 & \\
\hline Expansion Volume: & 114.36113 & \\
\hline Average Volume: & 27.634748 & \\
\hline Volume Standard Deviation: & 0.011835 & \\
\hline Average Density: & 2.659333 & \\
\hline Density Standard Deviation: & 0.001139 & \\
\hline Number of Runs: & 5 & \\
\hline Run Precision: & 0 & \\
\hline Percent Full: & 0.05 & \\
\hline
\end{tabular}

\begin{tabular}{|c|c|c|c|c|c|}
\hline Run Number & 1 & 2 & 3 & 4 & 5 \\
\hline P1 & 19.495298 & 19.515219 & 19.525089 & 19.52427 & 19.524015 \\
\hline P2 & 8.217615 & 8.224958 & 8.228578 & 8.228374 & 8.228115 \\
\hline Included/Excluded & 1 & 1 & 1 & 1 & 1 \\
\hline Elapsed Time & 693 & 829 & 969 & 1108 & 1252 \\
\hline Volume (cm^3) & 27.614767 & 27.633215 & 27.642679 & 27.64023 & 27.642853 \\
\hline Volume Deviation & -0.019981 & -0.001534 & 0.007931 & 0.005482 & 0.008104 \\
\hline Density (g/cm^3) & 2.661257 & 2.659481 & 2.65857 & 2.658806 & 2.658553 \\
\hline Density Deviation & 0.001924 & 0.000147 & -0.000763 & -0.000528 & -0.00078 \\
\hline
\end{tabular}


Sample 6-1-7 (Jacobsville Sandstone):

\begin{tabular}{|l|l|l|}
\hline Version Number: & "AccuPyc 1330 V2.01 " & \\
\hline Serial Number: & 0 & \\
\hline Report Type: & Analysis & \\
\hline Start Time: & $12 / 06 / 13$ & "14:16:11" \\
\hline End Time: & $12 / 06 / 13$ & \\
\hline Temperature: & 25.68232 & \\
\hline Sample ID: & $6-1-7$ & \\
\hline Sample Weight: & 72.07 & \\
\hline Number of Purges: & 10 & \\
\hline Equilibrium Rate: & 0.005 & \\
\hline Cell Volume: & 110.945335 & \\
\hline Expansion Volume: & 114.36113 & \\
\hline Average Volume: & 27.125399 & \\
\hline Volume Standard Deviation: & 0.00699 & \\
\hline Average Density: & 2.65692 & \\
\hline Density Standard Deviation: & 0.000685 & \\
\hline Number of Runs: & 5 & \\
\hline Run Precision: & 0 & \\
\hline Percent Full: & 0.05 & \\
\hline
\end{tabular}

\begin{tabular}{|c|c|c|c|c|c|}
\hline Run Number & 1 & 2 & 3 & 4 & 5 \\
\hline P1 & 19.486399 & 19.513689 & 19.511536 & 19.48226 & 19.483999 \\
\hline P2 & 8.241539 & 8.253932 & 8.252067 & 8.239709 & 8.240659 \\
\hline Included/Excluded & 1 & 1 & 1 & 1 & 1 \\
\hline Elapsed Time & 578 & 767 & 966 & 1138 & 1308 \\
\hline Volume (cm^3) & 27.12822 & 27.113243 & 27.130045 & 27.12964 & 27.125847 \\
\hline Volume Deviation & 0.002821 & -0.012156 & 0.004646 & 0.004238 & 0.000448 \\
\hline Density (g/cm^3) & 2.656643 & 2.658111 & 2.656464 & 2.656504 & 2.656876 \\
\hline Density Deviation & -0.000277 & 0.001191 & -0.000455 & -0.000415 & -0.000044 \\
\hline
\end{tabular}


Sample 6-1-8 (Jacobsville Sandstone):

\begin{tabular}{|l|l|l|}
\hline Version Number: & "AccuPyc 1330 V2.01 " & \\
\hline Serial Number: & 0 & \\
\hline Report Type: & Analysis & "14:40:13" \\
\hline Start Time: & $12 / 06 / 13$ & "14:59:55" \\
\hline End Time: & $12 / 06 / 13$ & \\
\hline Temperature: & 25.842855 & \\
\hline Sample ID: & $6-1-8$ & \\
\hline Sample Weight: & 68.940002 & \\
\hline Number of Purges: & 10 & \\
\hline Equilibrium Rate: & 0.005 & \\
\hline Cell Volume: & 110.945335 & \\
\hline Expansion Volume: & 114.36113 & \\
\hline Average Volume: & 25.897749 & \\
\hline Volume Standard Deviation: & 0.01236 & \\
\hline Average Density: & 2.662008 & \\
\hline Density Standard Deviation: & 0.001271 & \\
\hline Number of Runs: & 5 & \\
\hline Run Precision: & 0 & \\
\hline Percent Full: & 0.05 & \\
\hline
\end{tabular}

\begin{tabular}{|c|c|c|c|c|c|}
\hline Run Number & 1 & 2 & 3 & 4 & 5 \\
\hline P1 & 19.520185 & 19.509663 & 19.52062 & 19.51862 & 19.50754 \\
\hline P2 & 8.326557 & 8.320698 & 8.325048 & 8.324299 & 8.319718 \\
\hline Included/Excluded & 1 & 1 & 1 & 1 & 1 \\
\hline Elapsed Time & 586 & 734 & 879 & 1025 & 1174 \\
\hline Volume (cm^3) & 25.876003 & 25.900434 & 25.906183 & 25.90437 & 25.901754 \\
\hline Volume Deviation & -0.021746 & 0.002686 & 0.008434 & 0.006617 & 0.004005 \\
\hline Density (g/cm³) & 2.664245 & 2.661731 & 2.661141 & 2.661328 & 2.661596 \\
\hline Density Deviation & 0.002237 & -0.000277 & -0.000867 & -0.00068 & -0.000412 \\
\hline
\end{tabular}


Sample 6-1-9 (Jacobsville Sandstone):

\begin{tabular}{|l|l|l|}
\hline Version Number: & "AccuPyc 1330 V2.01 " & \\
\hline Serial Number: & 0 & \\
\hline Report Type: & Analysis & \\
\hline Start Time: & $14 / 04 / 13$ & "12:16:31" \\
\hline End Time: & $14 / 04 / 13$ & \\
\hline Temperature: & 26.963024 & \\
\hline Sample ID: & $6-1-9$ & \\
\hline Sample Weight: & 71.910004 & \\
\hline Number of Purges: & 10 & \\
\hline Equilibrium Rate: & 0.005 & \\
\hline Cell Volume: & 110.838661 & \\
\hline Expansion Volume: & 114.219429 & \\
\hline Average Volume: & 27.199038 & \\
\hline Volume Standard Deviation: & 0.007947 & \\
\hline Average Density: & 2.643844 & \\
\hline Density Standard Deviation: & 0.000772 & \\
\hline Number of Runs: & 5 & \\
\hline Run Precision: & 0 & \\
\hline Percent Full: & 0.05 & \\
\hline
\end{tabular}

\begin{tabular}{|c|c|c|c|c|c|}
\hline Run Number & 1 & 2 & 3 & 4 & 5 \\
\hline P1 & 19.496864 & 19.495375 & 19.491419 & 19.49145 & 19.494865 \\
\hline P2 & 8.241687 & 8.241468 & 8.240069 & 8.239168 & 8.240432 \\
\hline Included/Excluded & 1 & 1 & 1 & 1 & 1 \\
\hline Elapsed Time & 1090 & 1275 & 1455 & 1633 & 1814 \\
\hline Volume (cm^3) & 27.200642 & 27.193409 & 27.188604 & 27.20468 & 27.20785 \\
\hline Volume Deviation & 0.001604 & -0.005629 & -0.010433 & 0.005642 & 0.008812 \\
\hline Density (g/cm^3) & 2.643688 & 2.644391 & 2.644858 & 2.643296 & 2.642987 \\
\hline Density Deviation & -0.000156 & 0.000547 & 0.001014 & -0.000548 & -0.000857 \\
\hline
\end{tabular}


Sample 6-1-10 (Jacobsville Sandstone):

\begin{tabular}{|c|c|c|}
\hline Version Number: & $\begin{array}{l}\text { "AccuPyc } \\
1330 \text { V2.01 " }\end{array}$ & \\
\hline Serial Number: & 0 & \\
\hline Report Type: & Analysis & \\
\hline Start Time: & $13 / 06 / 13$ & "09:14:53" \\
\hline End Time: & $13 / 06 / 13$ & "09:33:57" \\
\hline Temperature: & 24.6414 & \\
\hline Sample ID: & $6-1-10$ & \\
\hline Sample Weight: & 65.52 & \\
\hline Number of Purges: & 10 & \\
\hline Equilibrium Rate: & 0.005 & \\
\hline Cell Volume: & 110.8744 & \\
\hline Expansion Volume: & 114.2415 & \\
\hline Average Volume: & 24.64523 & \\
\hline Volume Standard Deviation: & 0.015852 & \\
\hline Average Density: & 2.658528 & \\
\hline Density Standard Deviation: & 0.00171 & \\
\hline Number of Runs: & 5 & \\
\hline Run Precision: & 0 & \\
\hline Percent Full: & 0.05 & \\
\hline
\end{tabular}

\begin{tabular}{|c|r|l|l|l|r|}
\hline Run Number & 1 & 2 & 3 & 4 & \multicolumn{1}{l|}{5} \\
\hline P1 & 19.504 & 19.50453 & 19.50411 & 19.50508 & 19.5062 \\
\hline P2 & 8.390563 & 8.389699 & 8.389384 & 8.389597 & 8.389048 \\
\hline Included/excluded & 1 & 1 & 1 & 1 & 1 \\
\hline Elapsed time & 559 & 696 & 843 & 987 & 1136 \\
\hline Volume $\mathrm{cm}^{\wedge} 3$ & 24.62283 & 24.64252 & 24.64492 & 24.64863 & 24.66724 \\
\hline Volume deviation & -0.0224 & -0.00271 & -0.00031 & 0.003405 & 0.022009 \\
\hline Density g/cm^3 & 2.660945 & 2.658819 & 2.65856 & 2.658159 & 2.656155 \\
\hline Density deviation & 0.002417 & 0.000292 & 0.000032 & -0.00037 & -0.00237 \\
\hline
\end{tabular}


Sample 6-1-11 (Jacobsville Sandstone):

\begin{tabular}{|c|c|c|}
\hline Version Number: & $\begin{array}{l}\text { "AccuPyc } 1330 \\
\text { V2.01 " }\end{array}$ & \\
\hline Serial Number: & 0 & \\
\hline Report Type: & Analysis & \\
\hline Start Time: & $13 / 06 / 13$ & "09:42:54" \\
\hline End Time: & $13 / 06 / 13$ & "10:01:01" \\
\hline Temperature: & 24.71476 & \\
\hline Sample ID: & $6-1-11$ & \\
\hline Sample Weight: & 76.35 & \\
\hline Number of Purges: & 10 & \\
\hline Equilibrium Rate: & 0.005 & \\
\hline Cell Volume: & 110.8744 & \\
\hline Expansion Volume: & 114.2415 & \\
\hline Average Volume: & 28.85542 & \\
\hline Volume Standard Deviation: & 0.02341 & \\
\hline Average Density: & 2.645952 & \\
\hline Density Standard Deviation: & 0.002147 & \\
\hline Number of Runs: & 5 & \\
\hline Run Precision: & 0 & \\
\hline Percent Full: & 0.05 & \\
\hline
\end{tabular}

\begin{tabular}{|c|l|l|l|l|l|}
\hline Run Number & 1 & 2 & 3 & 4 & 5 \\
\hline P1 & 19.52052 & 19.51089 & 19.50545 & 19.52061 & 19.52094 \\
\hline P2 & 8.158604 & 8.155699 & 8.151095 & 8.156481 & 8.156974 \\
\hline Included/excluded & 1 & 1 & 1 & 1 & 1 \\
\hline Elapsed time & 524 & 677 & 807 & 945 & 1079 \\
\hline Volume cm^3 & 28.84143 & 28.82207 & 28.86229 & 28.8787 & 28.8726 \\
\hline Volume deviation & -0.01399 & -0.03335 & 0.00687 & 0.023285 & 0.017178 \\
\hline Density g/cm^3 & 2.647233 & 2.649011 & 2.64532 & 2.643817 & 2.644376 \\
\hline Density deviation & 0.001282 & 0.00306 & -0.00063 & -0.00214 & -0.00158 \\
\hline
\end{tabular}


Sample 6-1-12 (Jacobsville Sandstone):

\begin{tabular}{|l|r|l|}
\hline & \multicolumn{1}{|l|}{$\begin{array}{l}\text { "AccuPyc } \\
\text { Version Number: }\end{array}$} & \\
V2.01 " & \\
\hline Serial Number: & 0 & \\
\hline Report Type: & Analysis & \\
\hline & & \\
Start Time: & $13 / 06 / 13$ & "10:08:31" \\
\hline & & \\
End Time: & $13 / 06 / 13$ & "10:26:36" \\
\hline Temperature: & 24.78813 & \\
\hline Sample ID: & $6-1-12$ & \\
\hline Sample Weight: & 90.67 & \\
\hline Number of Purges: & 10 & \\
\hline Equilibrium Rate: & 0.005 & \\
\hline Cell Volume: & 110.8744 & \\
\hline Expansion Volume: & 114.2415 & \\
\hline Average Volume: & 34.29556 & \\
\hline $\begin{array}{l}\text { Volume Standard } \\
\text { Deviation: }\end{array}$ & 0.00825 & \\
\hline Average Density: & 2.643783 & \\
\hline Density Standard & & \\
Deviation: & 0.000636 & \\
\hline Number of Runs: & & \\
\hline Run Precision: & & \\
\hline Percent Full: & 0.05 & \\
\hline
\end{tabular}

\begin{tabular}{|c|r|l|l|l|l|}
\hline Run Number & 1 & 2 & 3 & 4 & 5 \\
\hline P1 & 19.50542 & 19.50472 & 19.50481 & 19.50486 & 19.50429 \\
\hline P2 & 7.828402 & 7.827934 & 7.827435 & 7.827208 & 7.826769 \\
\hline Included/excluded & 1 & 1 & 1 & 1 & 1 \\
\hline Elapsed time & 552 & 680 & 812 & 945 & 1077 \\
\hline Volume cm^3 & 34.28554 & 34.28861 & 34.29739 & 34.30141 & 34.30483 \\
\hline Volume deviation & -0.01001 & -0.00695 & 0.001831 & 0.005859 & 0.009274 \\
\hline Density g/cm^3 & 2.644555 & 2.644319 & 2.643641 & 2.643331 & 2.643068 \\
\hline Density deviation & 0.000772 & 0.000536 & -0.00014 & -0.00045 & -0.00072 \\
\hline
\end{tabular}


Sample 7-3 (Air Cooled Slag):

\begin{tabular}{|c|c|c|}
\hline Version Number: & $\begin{array}{l}\text { "AccuPyc } \\
1330 \\
\text { V2.01 " }\end{array}$ & \\
\hline Serial Number: & 0 & \\
\hline Report Type: & Analysis & \\
\hline Start Time: & $18 / 06 / 13$ & "10:45:09" \\
\hline End Time: & $18 / 06 / 13$ & "11:16:42" \\
\hline Temperature: & 21.59966 & \\
\hline Sample ID: & $7-3$ & \\
\hline Sample Weight: & 64.24 & \\
\hline Number of Purges: & 10 & \\
\hline Equilibrium Rate: & 0.005 & \\
\hline Cell Volume: & 110.8933 & \\
\hline Expansion Volume: & 114.2598 & \\
\hline Average Volume: & 21.74266 & \\
\hline $\begin{array}{l}\text { Volume Standard } \\
\text { Deviation: }\end{array}$ & 0.014358 & \\
\hline Average Density: & 2.954561 & \\
\hline $\begin{array}{l}\text { Density Standard } \\
\text { Deviation: }\end{array}$ & 0.001949 & \\
\hline Number of Runs: & 5 & \\
\hline Run Precision: & 0 & \\
\hline Percent Full: & 0.05 & \\
\hline
\end{tabular}

\begin{tabular}{|c|r|l|l|l|r|}
\hline Run Number & 1 & 2 & 3 & 4 & 5 \\
\hline P1 & 19.48607 & 19.49025 & 19.48912 & 19.48894 & 19.47801 \\
\hline P2 & 8.540933 & 8.542511 & 8.542001 & 8.541715 & 8.535467 \\
\hline Included/excluded & 1 & 1 & 1 & 1 & 1 \\
\hline Elapsed time & 813 & 1062 & 1331 & 1610 & 1885 \\
\hline Volume cm^3 & 21.73173 & 21.73652 & 21.73672 & 21.74061 & 21.76772 \\
\hline Volume deviation & -0.01093 & -0.00614 & -0.00594 & -0.00205 & 0.025059 \\
\hline Density g/cm^3 & 2.956046 & 2.955395 & 2.955367 & 2.954839 & 2.951159 \\
\hline Density deviation & 0.001485 & 0.000834 & 0.000806 & 0.000278 & -0.0034 \\
\hline
\end{tabular}


Sample 7-4 (Air Cooled Slag):

\begin{tabular}{|c|c|c|}
\hline Version Number: & $\begin{array}{l}\text { "AccuPyc } \\
1330 \text { V2.01 " }\end{array}$ & \\
\hline Serial Number: & 0 & \\
\hline Report Type: & Analysis & \\
\hline Start Time: & $13 / 06 / 13$ & "12:17:27" \\
\hline End Time: & $13 / 06 / 13$ & "12:51:42" \\
\hline Temperature: & 25.11968 & \\
\hline Sample ID: & $7-4$ & \\
\hline Sample Weight: & 28.38 & \\
\hline Number of Purges: & 10 & \\
\hline Equilibrium Rate: & 0.005 & \\
\hline Cell Volume: & 110.8744 & \\
\hline Expansion Volume: & 114.2415 & \\
\hline Average Volume: & 10.31947 & \\
\hline Volume Standard Deviation: & 0.002317 & \\
\hline Average Density: & 2.75014 & \\
\hline Density Standard Deviation: & 0.000617 & \\
\hline Number of Runs: & 5 & \\
\hline Run Precision: & 0 & \\
\hline Percent Full: & 0.05 & \\
\hline
\end{tabular}

\begin{tabular}{|c|r|l|l|l|l|}
\hline Run Number & 1 & 2 & 3 & 4 & 5 \\
\hline P1 & 19.47618 & 19.48168 & 19.48188 & 19.48075 & 19.48464 \\
\hline P2 & 9.117488 & 9.120256 & 9.120218 & 9.119866 & 9.121448 \\
\hline Included/excluded & 1 & 1 & 1 & 1 & 1 \\
\hline Elapsed time & 859 & 1160 & 1454 & 1755 & 2046 \\
\hline Volume cm^3 & 10.32153 & 10.31748 & 10.32025 & 10.31657 & 10.32154 \\
\hline Volume deviation & 0.002054 & -0.00199 & 0.000779 & -0.0029 & 0.002061 \\
\hline Density g/cm^3 & 2.749593 & 2.750671 & 2.749933 & 2.750914 & 2.749591 \\
\hline Density deviation & -0.00055 & 0.000531 & -0.00021 & 0.000774 & -0.00055 \\
\hline
\end{tabular}


Sample 7-6 (Air Cooled Slag):

\begin{tabular}{|c|c|c|}
\hline Version Number: & $\begin{array}{l}\text { "AccuPyc } 1330 \\
\text { V2.01 " }\end{array}$ & \\
\hline Serial Number: & 0 & \\
\hline Report Type: & Analysis & \\
\hline Start Time: & $13 / 06 / 13$ & "12:54:30" \\
\hline End Time: & $13 / 06 / 13$ & "13:19:58" \\
\hline Temperature: & 25.1864 & \\
\hline Sample ID: & $7-6$ & \\
\hline Sample Weight: & 46.87 & \\
\hline Number of Purges: & 10 & \\
\hline Equilibrium Rate: & 0.005 & \\
\hline Cell Volume: & 110.8744 & \\
\hline Expansion Volume: & 114.2415 & \\
\hline Average Volume: & 16.36939 & \\
\hline Volume Standard Deviation: & 0.025818 & \\
\hline Average Density: & 2.863276 & \\
\hline Density Standard Deviation: & 0.004518 & \\
\hline Number of Runs: & 5 & \\
\hline Run Precision: & 0 & \\
\hline Percent Full: & 0.05 & \\
\hline
\end{tabular}

\begin{tabular}{|c|r|l|l|l|r|}
\hline Run Number & 1 & 2 & 3 & 4 & \multicolumn{1}{l|}{5} \\
\hline P1 & 19.48662 & 19.48526 & 19.48499 & 19.48212 & 19.48138 \\
\hline P2 & 8.823929 & 8.822109 & 8.821386 & 8.819074 & 8.818233 \\
\hline Included/excluded & 1 & 1 & 1 & 1 & 1 \\
\hline Elapsed time & 704 & 906 & 1102 & 1311 & 1520 \\
\hline Volume cm^3 & 16.33355 & 16.3571 & 16.36892 & 16.38872 & 16.39866 \\
\hline Volume deviation & -0.03584 & -0.01229 & -0.00047 & 0.019329 & 0.02927 \\
\hline Density g/cm^3 & 2.869554 & 2.865422 & 2.863353 & 2.859894 & 2.85816 \\
\hline Density deviation & 0.006277 & 0.002146 & 0.000077 & -0.00338 & -0.00512 \\
\hline
\end{tabular}


Sample 7-7 (Air Cooled Slag):

\begin{tabular}{|c|c|c|}
\hline Version Number: & $\begin{array}{l}\text { "AccuPyc } 1330 \\
\text { V2.01 " }\end{array}$ & \\
\hline Serial Number: & 0 & \\
\hline Report Type: & Analysis & \\
\hline Start Time: & $18 / 06 / 13$ & "08:22:16" \\
\hline End Time: & $18 / 06 / 13$ & "10:04:13" \\
\hline Temperature: & 20.42811 & \\
\hline Sample ID: & $7-7$ & \\
\hline Sample Weight: & 71.75 & \\
\hline Number of Purges: & 10 & \\
\hline Equilibrium Rate: & 0.005 & \\
\hline Cell Volume: & 110.8933 & \\
\hline Expansion Volume: & 114.2598 & \\
\hline Average Volume: & 25.85272 & \\
\hline Volume Standard Deviation: & 0.07625 & \\
\hline Average Density: & 2.775356 & \\
\hline Density Standard Deviation: & 0.008164 & \\
\hline Number of Runs: & 5 & \\
\hline Run Precision: & 0 & \\
\hline Percent Full: & 0.05 & \\
\hline
\end{tabular}

\begin{tabular}{|c|r|l|l|l|l|}
\hline Run Number & 1 & 2 & 3 & 4 & 5 \\
\hline P1 & 19.42479 & 19.41039 & 19.42383 & 19.39933 & 19.40504 \\
\hline P2 & 8.288977 & 8.285497 & 8.280985 & 8.281102 & 8.279944 \\
\hline Included/excluded & 1 & 1 & 1 & 1 & 1 \\
\hline Elapsed time & 2236 & 3247 & 4072 & 5134 & 6109 \\
\hline Volume $\mathrm{cm}^{\wedge} 3$ & 25.84369 & 25.79596 & 25.97933 & 25.79011 & 25.85453 \\
\hline Volume deviation & -0.00903 & -0.05677 & 0.126606 & -0.06261 & 0.001806 \\
\hline Density g/cm^3 & 2.776307 & 2.781444 & 2.761811 & 2.782074 & 2.775143 \\
\hline Density deviation & 0.000951 & 0.006088 & -0.01354 & 0.006718 & -0.00021 \\
\hline
\end{tabular}




\section{CALIBRATION REPORTS:}

\begin{tabular}{|l|l|l|}
\hline Version Number & "AccuPyc 1330 V2.01 " & \\
\hline Serial Number & 0 & \\
\hline Report Type & Calibration & \\
\hline Start & $14 / 04 / 13$ & "11:14:30" \\
\hline Stop & $14 / 04 / 13$ & "12:13:38" \\
\hline Temp & 26.858473 & \\
\hline Calibration Standard Size & 51.089642 & \\
\hline Number of Purges & 10 & \\
\hline Equilibrium Rate & 0.005 & \\
\hline Average Cell Volume & 110.838661 & \\
\hline Cell Volume Standard Deviation & 0.011489 & \\
\hline Average Expansion Volume & 114.219429 & \\
\hline Expansion Volume Standard Deviation & 0.017616 & \\
\hline Number of Runs & 5 & \\
\hline
\end{tabular}

\begin{tabular}{|c|c|c|c|c|c|}
\hline Run Number & 1 & 2 & 3 & 4 & 5 \\
\hline P1 & 19.49182 & 19.49165 & 19.49029 & 19.49033 & 19.49093 \\
\hline P2 & 9.599787 & 9.599782 & 9.598815 & 9.598638 & 9.598519 \\
\hline P1* & 19.49261 & 19.49217 & 19.49048 & 19.49259 & 19.49133 \\
\hline P2* & 6.695297 & 6.694247 & 6.694034 & 6.69447 & 6.694057 \\
\hline Average & 1 & 1 & 1 & 1 & 1 \\
\hline Cell Volume & 110.8493 & 110.8206 & 110.8394 & 110.8362 & 110.8477 \\
\hline Cell Volume Deviation & 0.010681 & -0.01803 & 0.000778 & -0.0025 & 0.009056 \\
\hline Expansion Volume & 114.224 & 114.1925 & 114.2188 & 114.2201 & 114.2417 \\
\hline Expansion Volume Deviation & 0.0045 & -0.02 & 0 & 0 & 0.0222 \\
\hline
\end{tabular}




\begin{tabular}{|l|l|l|}
\hline Version Number & "AccuPyc 1330 V2.01 " & \\
\hline Serial Number & 0 & \\
\hline Report Type & Calibration & \\
\hline Start & $17 / 04 / 13$ & "11:28:08" \\
\hline Stop & $17 / 04 / 13$ & "13:30:48" \\
\hline Temp & 25.423878 & \\
\hline Calibration Standard Size & 51.089642 & \\
\hline Number of Purges & 10 & \\
\hline Equilibrium Rate & 0.005 & \\
\hline Average Cell Volume & 110.823776 & \\
\hline Cell Volume Standard Deviation & 0.029676 & \\
\hline AVG Expansion Volume & 114.171974 & \\
\hline Expansion Volume Standard Deviation & 0.047493 & \\
\hline Number of Runs & 5 & \\
\hline
\end{tabular}

\begin{tabular}{|c|c|c|c|c|c|}
\hline Run Number & 1 & 2 & 3 & 4 & 5 \\
\hline P1 & 19.49172 & 19.49203 & 19.49058 & 19.49039 & 19.4903 \\
\hline P2 & 9.601752 & 9.601269 & 9.600769 & 9.599349 & 9.599247 \\
\hline P1* & 19.49081 & 19.49061 & 19.49035 & 19.49178 & 19.49062 \\
\hline P2* & 6.695189 & 6.695043 & 6.693641 & 6.695445 & 6.694727 \\
\hline Average & 1 & 1 & 1 & 1 & 1 \\
\hline Cell Volume & 110.8108 & 110.8253 & 110.7809 & 110.855 & 110.847 \\
\hline Cell Volume Deviation & -0.013 & 0.001503 & -0.04289 & 0.031181 & 0.023224 \\
\hline Expansion Volume & 114.137 & 114.1668 & 114.116 & 114.2235 & 114.2166 \\
\hline Expansion Volume Deviation & -0.03 & -0.005 & -0.05 & 0.0515 & 0.0445 \\
\hline
\end{tabular}




\begin{tabular}{|l|l|l|}
\hline Version Number & "AccuPyc 1330 V2.01 " & \\
\hline Serial Number & 0 & \\
\hline Report Type & Calibration & \\
\hline Start & $18 / 04 / 13$ & "06:58:53" \\
\hline Stop & $18 / 04 / 13$ & \\
\hline Temp & 25.88938 & \\
\hline Calibration Standard Size & 51.089642 & \\
\hline Number of Purges & 10 & \\
\hline Equilibrium Rate & 0.005 & \\
\hline Average Cell Volume & 110.860016 & \\
\hline Cell Volume Standard Deviation & 0.059704 & \\
\hline AVG Expansion Volume & 114.226265 & \\
\hline Expansion Volume Standard Deviation & 0.061575 & \\
\hline Number of Runs & 5 & \\
\hline
\end{tabular}

\begin{tabular}{|c|c|c|c|c|c|}
\hline Run Number & 1 & 2 & 3 & 4 & 5 \\
\hline $\mathrm{P} 1$ & 19.49107 & 19.4904 & 19.49035 & 19.49131 & 19.49106 \\
\hline $\mathrm{P} 2$ & 9.599816 & 9.59969 & 9.599429 & 9.599994 & 9.599436 \\
\hline P1* & 19.49061 & 19.49051 & 19.49188 & 19.49059 & 19.49062 \\
\hline $\mathrm{P} 2 *$ & 6.694833 & 6.695286 & 6.69917 & 6.693473 & 6.69417 \\
\hline AVG & 1 & 1 & 1 & 1 & 1 \\
\hline Cell Volume & 110.8452 & 110.8542 & 110.9613 & 110.8038 & 110.8356 \\
\hline Cell Volume Deviation & -0.01486 & -0.00578 & 0.101234 & -0.05623 & -0.02437 \\
\hline Expansion Volume & 114.2102 & 114.2149 & 114.3306 & 114.1663 & 114.2093 \\
\hline Expansion Volume Deviation & -0.01 & -0.01 & 0.1043 & -0.05 & -0.01 \\
\hline
\end{tabular}




\begin{tabular}{|l|l|l|}
\hline Version Number & AccuPyc 1330 V2.01 & \\
\hline Serial Number & 0 & \\
\hline Report Type & Calibration & \\
\hline Start & $23 / 04 / 13$ & "08:04:27" \\
\hline Stop & $23 / 04 / 13$ & "08:44:39" \\
\hline Temp & 26.693848 & \\
\hline Calibration Standard Size & 51.089642 & \\
\hline Number of Purges & 10 & \\
\hline Equilibrium Rate & 0.005 & \\
\hline Average Cell Volume & 110.890297 & \\
\hline Cell Volume Standard Deviation & 0.031524 & \\
\hline AVG Expansion Volume & 114.27034 & \\
\hline Expansion Volume Standard Deviation & 0.044697 & \\
\hline Number of Runs & 5 & \\
\hline
\end{tabular}

\begin{tabular}{|c|c|c|c|c|c|}
\hline Run Number & 1 & 2 & 3 & 4 & 5 \\
\hline $\mathrm{P} 1$ & 19.49144 & 19.49366 & 19.50349 & 19.49511 & 19.50495 \\
\hline $\mathrm{P} 2$ & 9.598552 & 9.600565 & 9.605758 & 9.601048 & 9.606672 \\
\hline $\mathrm{P} 1^{*}$ & 19.50635 & 19.51345 & 19.51332 & 19.51454 & 19.51498 \\
\hline $\mathrm{P} 2 *$ & 6.70234 & 6.703322 & 6.703753 & 6.703453 & 6.703968 \\
\hline Average & 1 & 1 & 1 & 1 & 1 \\
\hline Cell Volume & 110.9457 & 110.8783 & 110.883 & 110.8772 & 110.8672 \\
\hline Cell Volume Deviation & 0.05545 & -0.01202 & -0.00731 & -0.01307 & -0.02306 \\
\hline Expansion Volume & 114.3478 & 114.2568 & 114.2534 & 114.2611 & 114.2325 \\
\hline Expansion Volume Deviation & 0.0774 & -0.01 & -0.01 & 0 & -0.03 \\
\hline
\end{tabular}




\begin{tabular}{|l|l|l|}
\hline Version Number & AccuPyc 1330 V2.01 & \\
\hline Serial Number & 0 & \\
\hline Report Type & Calibration & \\
\hline Start & $12 / 06 / 13$ & "09:27:58" \\
\hline Stop & $12 / 06 / 13$ & "10:29:32" \\
\hline Temp & 23.869139 & \\
\hline Calibration Standard Size & 51.089642 & \\
\hline Number of Purges & 10 & \\
\hline Equilibrium Rate & 0.005 & \\
\hline Average Cell Volume & 110.945335 & \\
\hline Cell Volume Standard Deviation & 0.025776 & \\
\hline AVG Expansion Volume & 114.36113 & \\
\hline Expansion Volume Standard Deviation & 0.022351 & \\
\hline Number of Runs & 5 & \\
\hline
\end{tabular}

\begin{tabular}{|c|c|c|c|c|c|}
\hline Run Number & 1 & 2 & 3 & 4 & 5 \\
\hline P1 & 19.50586 & 19.50802 & 19.50967 & 19.50006 & 19.51019 \\
\hline P2 & 9.605418 & 9.606504 & 9.607008 & 9.601705 & 9.606924 \\
\hline P1* & 19.50044 & 19.50164 & 19.50157 & 19.50182 & 19.4953 \\
\hline P2* & 6.701578 & 6.700498 & 6.699695 & 6.699518 & 6.697062 \\
\hline Average & 1 & 1 & 1 & 1 & 1 \\
\hline Cell Volume & 110.9895 & 110.9447 & 110.9301 & 110.9375 & 110.925 \\
\hline Cell Volume Deviation & 0.044128 & -0.00063 & -0.01526 & -0.00787 & -0.02038 \\
\hline Expansion Volume & 114.3984 & 114.3517 & 114.344 & 114.365 & 114.3466 \\
\hline Expansion Volume Deviation & 0.0372 & 0 & -0.01 & 0.003 & -0.01 \\
\hline
\end{tabular}




\section{Appendix H: Raw Data for Water Immersion Trials}

One of the drawbacks to the Surface Saturated Dry (SSD) method for determining the particle density of a material is that a critical assumption that must be made is not entirely accurate. This assumption is that the time it takes to fully saturate the sample and have the internal pore structure filled with water is twenty four hours. In order to test this assumption water immersion trials were completed on the samples.

During this portion of testing the samples were dried in an over set at $110^{\circ} \mathrm{C}$ for at least 24 hours. After cooling to room temperature the samples were first weighed to determine the dry weight of the samples and then immersed in water. As with other testing the specific gravity of the water was also tested using a $152 \mathrm{H}$ hydrometer to ensure that it was at 1 $\mathrm{g} / \mathrm{cm}^{3}$.

Over the next twenty four hours the samples were removed every 1-4 hours and re-weighed. During this process as with the procedure in discussed for SSD an attempt was made to retain the water trapped in the surface pores of the sample. For some samples this was easier than others. For samples containing large surface pores such as the air or water cooled blast slag it was very difficult to keep the water in the surface pores, where as for samples such as Granite or the Kona Dolomite it was simpler.

After being weighed the samples were then placed back into the water. While testing the weight of the sample was plotted against time. Ideally this curve would reach a plateau, or a point where the weight was not changing despite time continuing the progress. This would mark the point where the internal pores were filled with water. The amount of time is would take for a rock to achieve this plateau varies depending upon the individual characteristics of the rock.

Initially sixteen samples were tested and later on in order to better understand the variability of some of the rock types another twelve samples were tested. These later samples consisted mainly of the blast slag samples and some of the Various Carbonates as well.

The original raw data can be seen below in Tables $\mathrm{H}-1$ and $\mathrm{H}-2$. Table $\mathrm{H}-1$ is the original sixteen samples and Table $\mathrm{H}-2$ is the second group of twelve rock samples, and each table is organized in order to show the rock type that was tested, the sample number as well as the weight and time each measurement was taken. 


\begin{tabular}{|c|c|c|c|c|c|c|c|c|c|}
\hline \multicolumn{2}{|c|}{ Rock Type } & Granite & Granite & $\begin{array}{c}\text { Kona } \\
\text { Dolomite }\end{array}$ & $\begin{array}{c}\text { Kona } \\
\text { Dolomite }\end{array}$ & $\begin{array}{c}\text { Pelkie } \\
\text { Limestone }\end{array}$ & $\begin{array}{c}\text { Pelkie } \\
\text { Limestone }\end{array}$ & $\begin{array}{c}\text { Various } \\
\text { Carbonates }\end{array}$ & $\begin{array}{c}\text { Various } \\
\text { Carbonates }\end{array}$ \\
\hline \multicolumn{2}{|c|}{ Sample ID } & $1-1-1$ & $1-1-4$ & $2-1-4$ & $2-2-5$ & $3-2-1$ & $3-3-1$ & 4-1-1 & $4-2-3$ \\
\hline \multirow{16}{*}{$\begin{array}{c}\text { Time } \\
\text { (Hours) }\end{array}$} & 0 & 704.42 & 444.37 & 511.97 & 502.06 & 276.14 & 338.75 & 488.64 & 478.02 \\
\hline & 1 & 704.77 & 444.67 & 512.38 & 502.16 & 277.78 & 340.58 & 489.37 & 480.56 \\
\hline & 2 & 704.86 & 444.67 & 512.44 & 502.21 & 278.36 & 341.24 & 489.44 & 481.18 \\
\hline & 3 & 704.93 & 444.73 & 512.48 & 502.26 & 278.74 & 341.63 & 489.49 & 481.79 \\
\hline & 4 & 705.01 & 444.77 & 512.53 & 502.34 & 279.1 & 342 & 489.58 & 482.25 \\
\hline & 5 & 705.01 & 444.78 & 512.52 & 502.33 & 279.35 & 342.18 & 489.58 & 482.69 \\
\hline & 6 & 704.99 & 444.74 & 512.52 & 502.34 & 279.48 & 342.36 & 489.54 & 482.89 \\
\hline & 7 & 704.99 & 444.79 & 512.52 & 502.41 & 279.69 & 342.47 & 489.57 & 483.27 \\
\hline & 8 & 705.17 & 444.8 & 512.56 & 502.4 & 279.84 & 342.54 & 489.63 & 483.5 \\
\hline & 9 & 705.02 & 444.73 & 512.58 & 502.36 & 279.99 & 342.68 & 489.65 & 483.1 \\
\hline & 10 & 705.04 & 444.81 & 512.56 & 502.43 & 280.06 & 342.7 & 489.15 & 483.86 \\
\hline & 12 & 705.04 & 444.89 & 512.58 & 502.5 & 280.31 & 342.89 & 489.72 & 484.33 \\
\hline & 15 & 705.01 & 444.79 & 512.49 & 502.45 & 280.4 & 342.84 & 489.59 & 484.51 \\
\hline & 19 & 705.01 & 444.79 & 512.56 & 502.43 & 280.61 & 342.9 & 489.69 & 484.86 \\
\hline & 23 & 704.99 & 444.83 & 512.56 & 502.48 & 280.74 & 342.95 & 489.77 & 485.12 \\
\hline & 96 & 705.76 & 445.34 & 513.4 & 503.24 & 281.46 & 343.71 & 490.77 & 486.42 \\
\hline
\end{tabular}

Table H-1: First round of water immersion testing. Remainder of samples from round one can be seen in Table $\mathrm{H}-2$ below 


\begin{tabular}{|c|c|c|c|c|c|c|c|c|c|}
\hline \multicolumn{2}{|c|}{ Rock Type } & $\begin{array}{c}\text { Various } \\
\text { Carbonates }\end{array}$ & $\begin{array}{c}\text { Various } \\
\text { Carbonates }\end{array}$ & $\begin{array}{c}\text { Water } \\
\text { Cooled } \\
\text { Slag }\end{array}$ & $\begin{array}{c}\text { Water } \\
\text { Cooled } \\
\text { Slag }\end{array}$ & $\begin{array}{l}\text { Jacobsville } \\
\text { Sandstone }\end{array}$ & $\begin{array}{l}\text { Jacobsville } \\
\text { Sandstone }\end{array}$ & $\begin{array}{c}\text { Air } \\
\text { Cooled } \\
\text { Slag }\end{array}$ & $\begin{array}{c}\text { Air Cooled } \\
\text { Slag } \\
\end{array}$ \\
\hline \multicolumn{2}{|c|}{ Sample ID } & 4-3-3 & 4-4-2 & $5-1-3$ & $5-3-3$ & 6-1-8 & $6-1-9$ & $7-2$ & 7-6 \\
\hline \multirow{16}{*}{$\begin{array}{l}\text { Time } \\
\text { (Hours) }\end{array}$} & 0 & 331.52 & 412.31 & 433.81 & 349.76 & 378.53 & 379.71 & 432.84 & 440.04 \\
\hline & 1 & 333.18 & 415 & 444.58 & 368.68 & 391.44 & 393.4 & 452.77 & 456.48 \\
\hline & 2 & 333.75 & 415.71 & 447.25 & 369.43 & 395.77 & 397.53 & 453.65 & 457.98 \\
\hline & 3 & 334.13 & 415.96 & 450.1 & 371.21 & 397.98 & 399.3 & 452.56 & 458.35 \\
\hline & 4 & 334.45 & 416.26 & 449.94 & 373.78 & 398.69 & 400.1 & 456.45 & 462.18 \\
\hline & 5 & 334.7 & 416.68 & 458.01 & 375.23 & 398.79 & 400.09 & 451.35 & 460.21 \\
\hline & 6 & 334.85 & 416.92 & 457.34 & 387.39 & 398.8 & 400.09 & 470.53 & 464.16 \\
\hline & 7 & 335.05 & 417.66 & 460.25 & 389.37 & 398.85 & 400.01 & 474.88 & 471.52 \\
\hline & 8 & 335.21 & 417.91 & 471.47 & 377.67 & 398.92 & 400.03 & 468.91 & 481.82 \\
\hline & 9 & 335.39 & 417.69 & 477.84 & 404.72 & 398.88 & 400.1 & 474.69 & 479.13 \\
\hline & 10 & 335.37 & 418.03 & 460.43 & 383.84 & 398.96 & 400.27 & 476.24 & 465.57 \\
\hline & 12 & 335.59 & 418.59 & 472.98 & 394.79 & 399.02 & 400.31 & 469.69 & 477.01 \\
\hline & 15 & 335.59 & 418.45 & 470.41 & 404.79 & 398.42 & 400.3 & 471.3 & 481.12 \\
\hline & 19 & 335.67 & 418.97 & 473.29 & 392.62 & 398.17 & 400.52 & 460.11 & 482.51 \\
\hline & 23 & 335.68 & 419.44 & 465.26 & 392.58 & 399.33 & 400.9 & 476.97 & 483.64 \\
\hline & 96 & 336.22 & 420.12 & 455.44 & 380.08 & 402.14 & 402.7 & 454.46 & 466.66 \\
\hline
\end{tabular}

Table H-2: Remaining samples from round one of water immersion testing 


\begin{tabular}{|c|c|c|c|c|c|c|c|c|c|c|c|c|c|}
\hline \multicolumn{2}{|c|}{ Rock Type } & $\begin{array}{c}\text { Various } \\
\text { Carbonates }\end{array}$ & $\begin{array}{c}\text { Various } \\
\text { Carbonates }\end{array}$ & $\begin{array}{c}\text { Various } \\
\text { Carbonates }\end{array}$ & $\begin{array}{c}\text { Water } \\
\text { Cooled } \\
\text { Slag } \\
\end{array}$ & $\begin{array}{c}\text { Water } \\
\text { Cooled } \\
\text { Slag } \\
\end{array}$ & $\begin{array}{c}\text { Water } \\
\text { Cooled } \\
\text { Slag }\end{array}$ & $\begin{array}{c}\text { Water } \\
\text { Cooled } \\
\text { Slag }\end{array}$ & $\begin{array}{c}\text { Water } \\
\text { Cooled } \\
\text { Slag } \\
\end{array}$ & $\begin{array}{c}\text { Water } \\
\text { Cooled } \\
\text { Slag }\end{array}$ & $\begin{array}{l}\text { Jacobsville } \\
\text { Sandstone }\end{array}$ & $\begin{array}{c}\text { Air } \\
\text { Cooled } \\
\text { Slag } \\
\end{array}$ & $\begin{array}{c}\text { Air } \\
\text { Cooled } \\
\text { Slag } \\
\end{array}$ \\
\hline \multicolumn{2}{|c|}{ Sample ID } & $4-1-2$ & $4-1-5$ & $4-2-1$ & $5-1-1$ & $5-1-4$ & $5-2-1$ & $5-2-2$ & $5-2-3$ & 5-3-1 & $6-1-12$ & $7-2$ & $7-5$ \\
\hline \multirow{16}{*}{$\begin{array}{l}\text { Time } \\
\text { (Hours) }\end{array}$} & 0 & 491.43 & 468.93 & 448.3 & 419.36 & 425.79 & 366.71 & 451.2 & 507.81 & 390.28 & 378.49 & 432.58 & 459.31 \\
\hline & 1 & 494.25 & 471.15 & 452.06 & 446.14 & 454.52 & 397.99 & 467.88 & 549.48 & 416.28 & 392.72 & 457.39 & 492.64 \\
\hline & 2 & 494.82 & 471.1 & 454.51 & 451.41 & 446.05 & 396.76 & 473.41 & 547.92 & 433.53 & 397.1 & 464.52 & 496.44 \\
\hline & 3 & 494.11 & 471.37 & 453.62 & 452.16 & 443.48 & 419.41 & 490.03 & 528.79 & 431.52 & 398.4 & 480.67 & 487.69 \\
\hline & 4 & 494.33 & 471.75 & 453.56 & 459.96 & 455.2 & 413.34 & 492.36 & 543.14 & 441.53 & 398.46 & 489.58 & 485.85 \\
\hline & 5 & 494.17 & 471.77 & 453.92 & 461.26 & 463.58 & 432.54 & 484.92 & 553.01 & 434.47 & 398.84 & 476.17 & 509.6 \\
\hline & 6 & 494.37 & 471.94 & 454.33 & 461.52 & 447.03 & 427.81 & 495.34 & 540.85 & 441.78 & 398.72 & 472.39 & 492.75 \\
\hline & 7 & 495.04 & 470.98 & 453.92 & 462.7 & 467.83 & 435.96 & 486.81 & 537.81 & 436.02 & 399.12 & 469.25 & 485.16 \\
\hline & 8 & 493.99 & 471.47 & 453.5 & 449.44 & 466.53 & 402.02 & 490.64 & 547.22 & 437.19 & 399.06 & 461.9 & 506.04 \\
\hline & 9 & 493.42 & 471.25 & 454.36 & 481.3 & 462.16 & 438.6 & 503.15 & 558.63 & 425.84 & 398.88 & 475.18 & 506.21 \\
\hline & 10 & 496.32 & 471.25 & 454.69 & 473.4 & 456.05 & 410.22 & 486.61 & 530.53 & 428.65 & 399.41 & 495.15 & 499.03 \\
\hline & 11 & 494.36 & 471.35 & 454.53 & 456.16 & 457.82 & 430.64 & 481.38 & 534.98 & 425.73 & 398.8 & 486.16 & 486.01 \\
\hline & 12 & 494.27 & 471.22 & 454.6 & 477.87 & 483.1 & 414.47 & 473.32 & 541.63 & 426.47 & 399.58 & 468.69 & 495.89 \\
\hline & 14 & 493.64 & 471.24 & 455.68 & 481.03 & 458.65 & 412.19 & 468.28 & 543.57 & 432.43 & 399.03 & 462.16 & 489.67 \\
\hline & 18 & 493.62 & 470.7 & 455.34 & 454.6 & 450.73 & 420.97 & 478.75 & 544.84 & 429.05 & 398.94 & 474.22 & 492.7 \\
\hline & 24 & 493.48 & 471.22 & 455.65 & 451.02 & 456.33 & 417.23 & 477.3 & 540 & 428.48 & 399.33 & 478.48 & 495.43 \\
\hline
\end{tabular}

Table H-3: Weight and time results for the second round of water immersion testing. 
The following graphs are the weight $v$ time plots created for each of the samples for both trials. They are organized by rock type and sample number below.

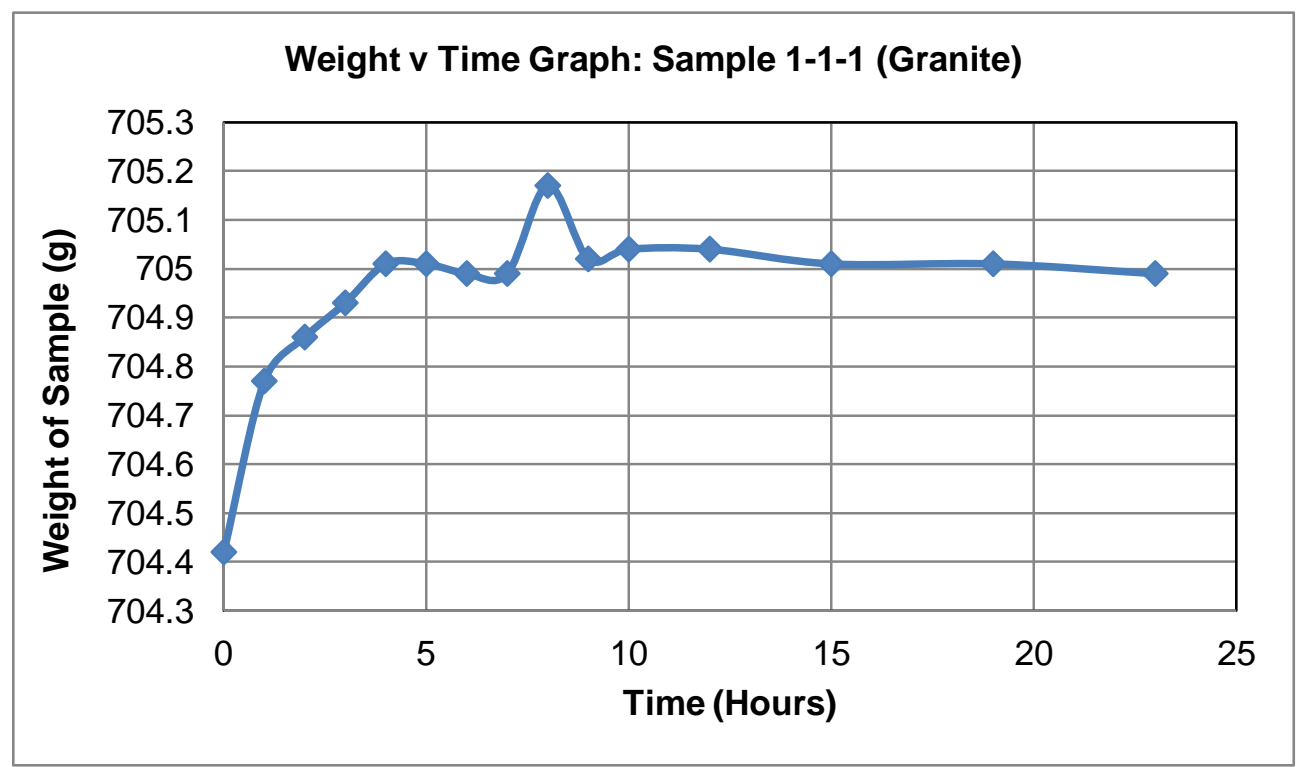

Figure H-1: Weight v Time Graph for sample 1-1-1 (Granite)

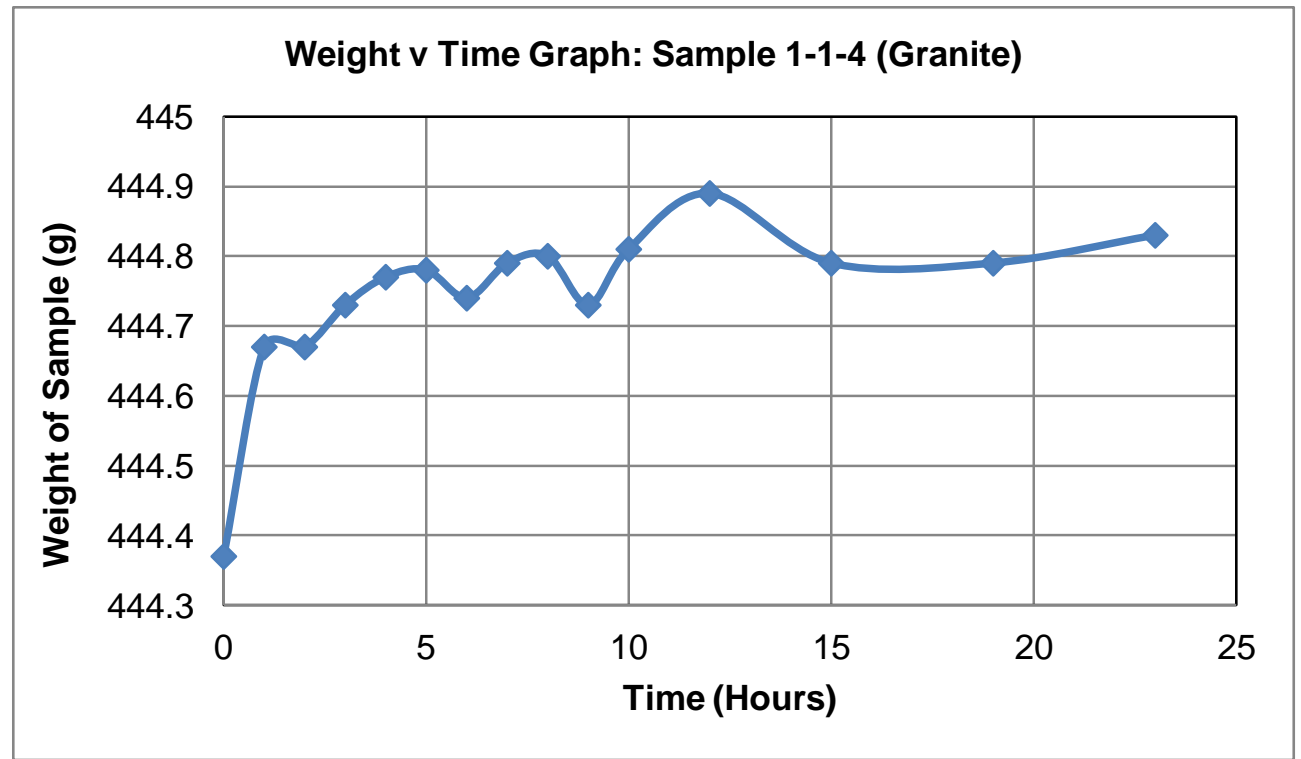

Figure H-2: Weight v Time Graph for sample 1-1-4 (Granite) 


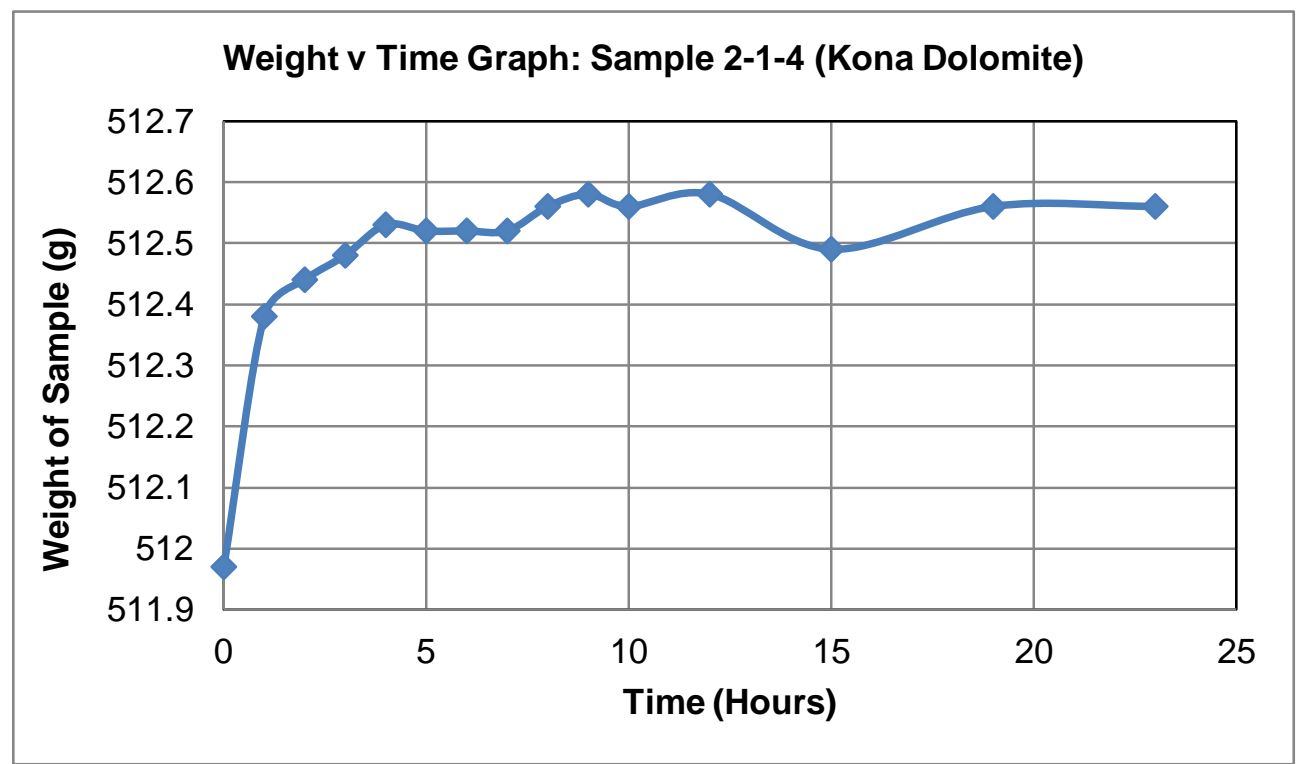

Figure H-3: Weight v Time Graph for sample 2-1-4 (Kona Dolomite)

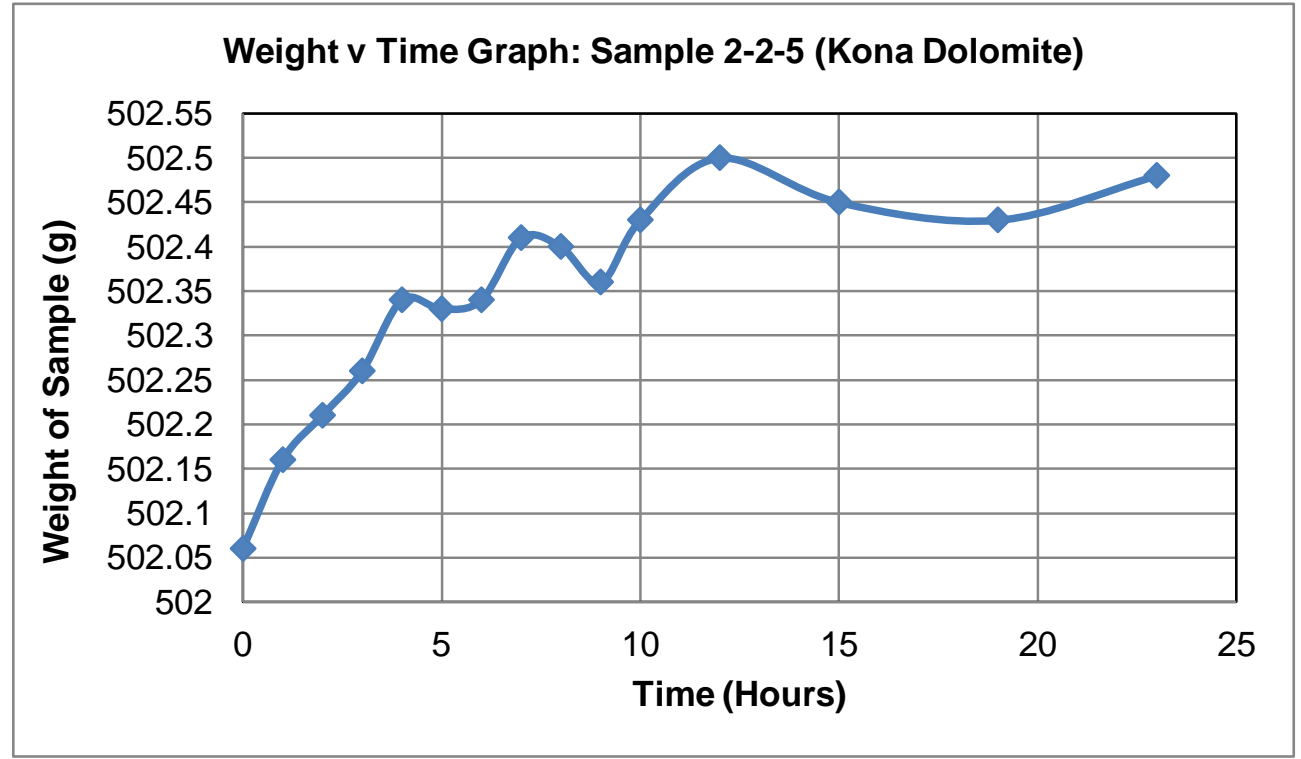

Figure H-4: Weight v Time Graph for sample 2-2-5 (Kona Dolomite) 


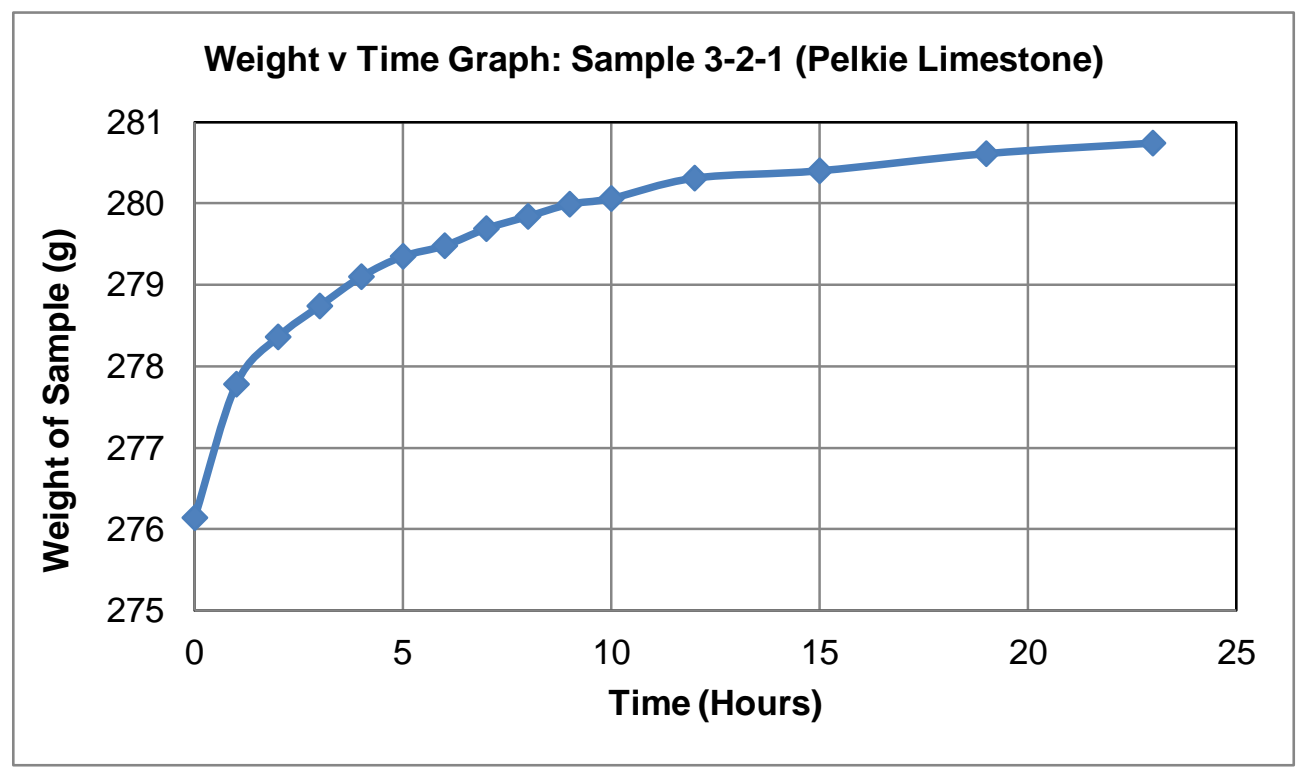

Figure H-5: Weight v Time Graph for sample 3-2-1 (Pelkie Limestone)

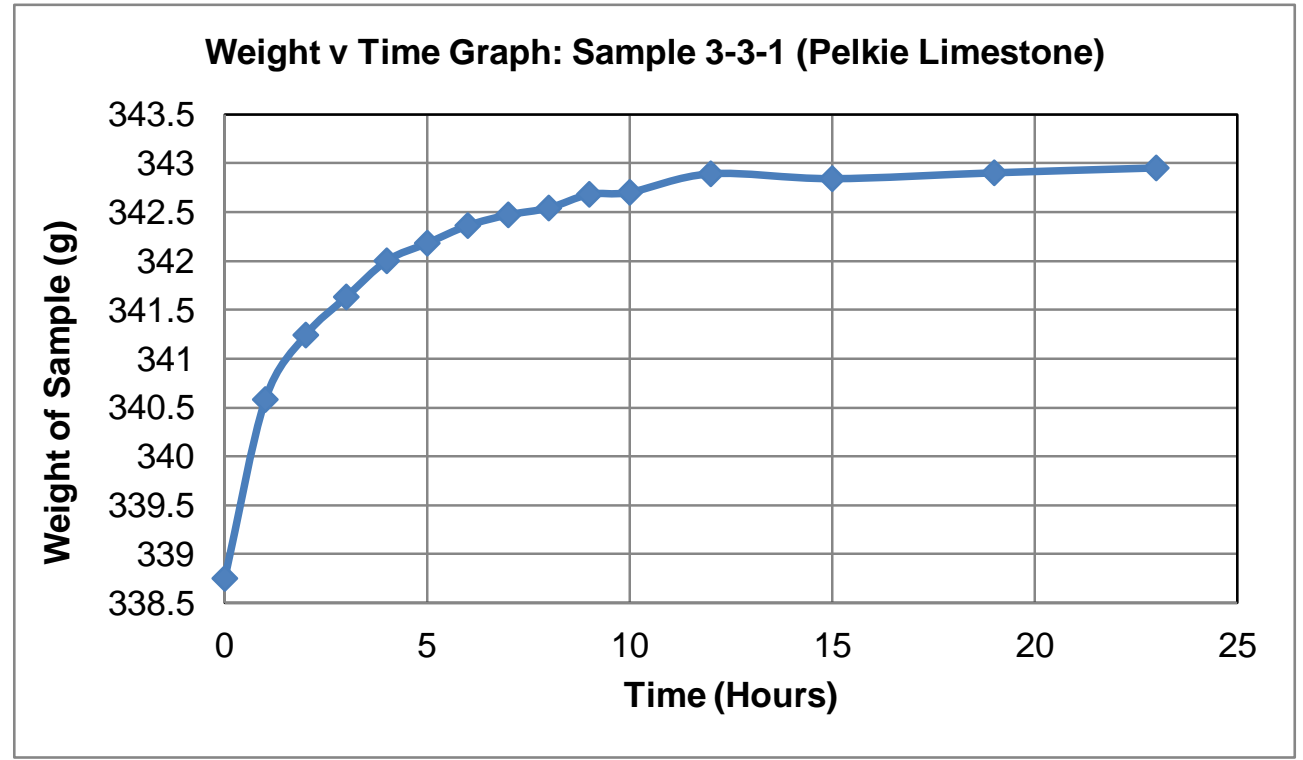

Figure H-6: Weight v Time Graph for sample 3-3-1 (Pelkie Limestone) 


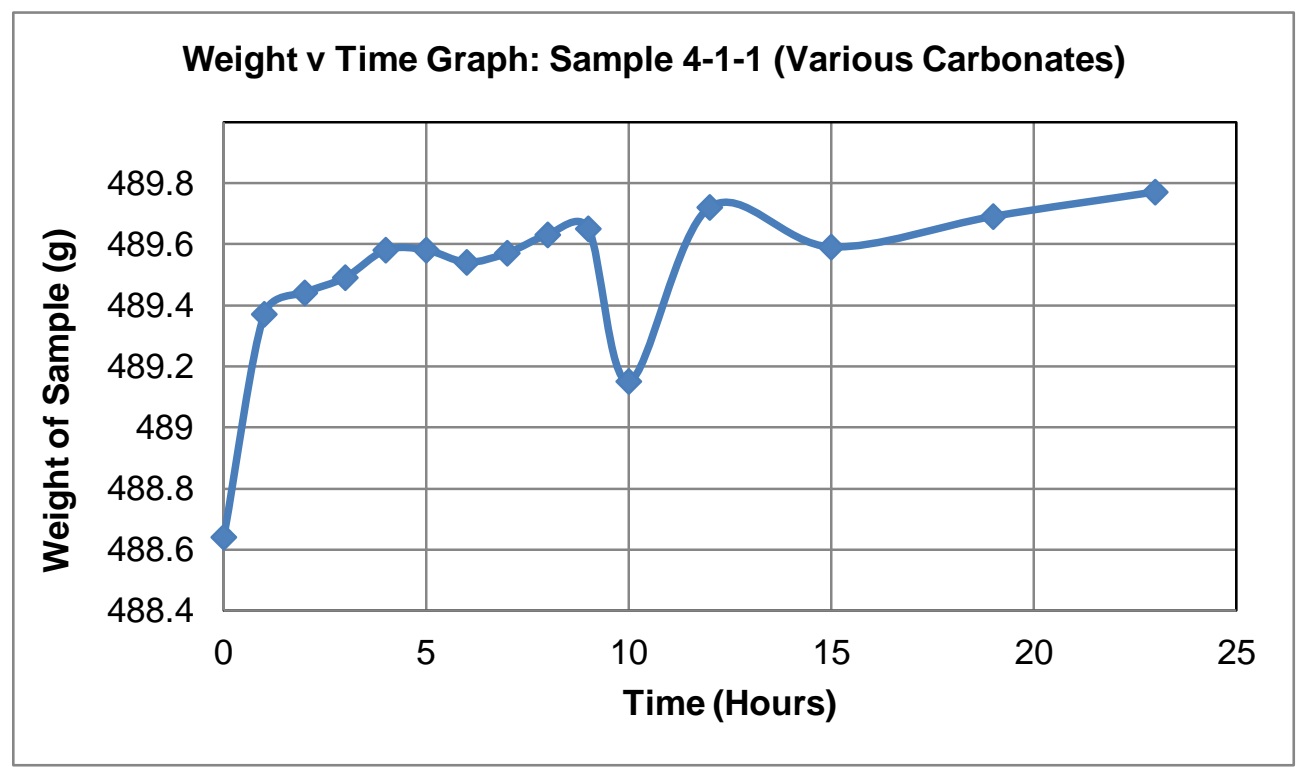

Figure H-7: Weight v Time Graph for sample 4-1-1 (Various Carbonates)

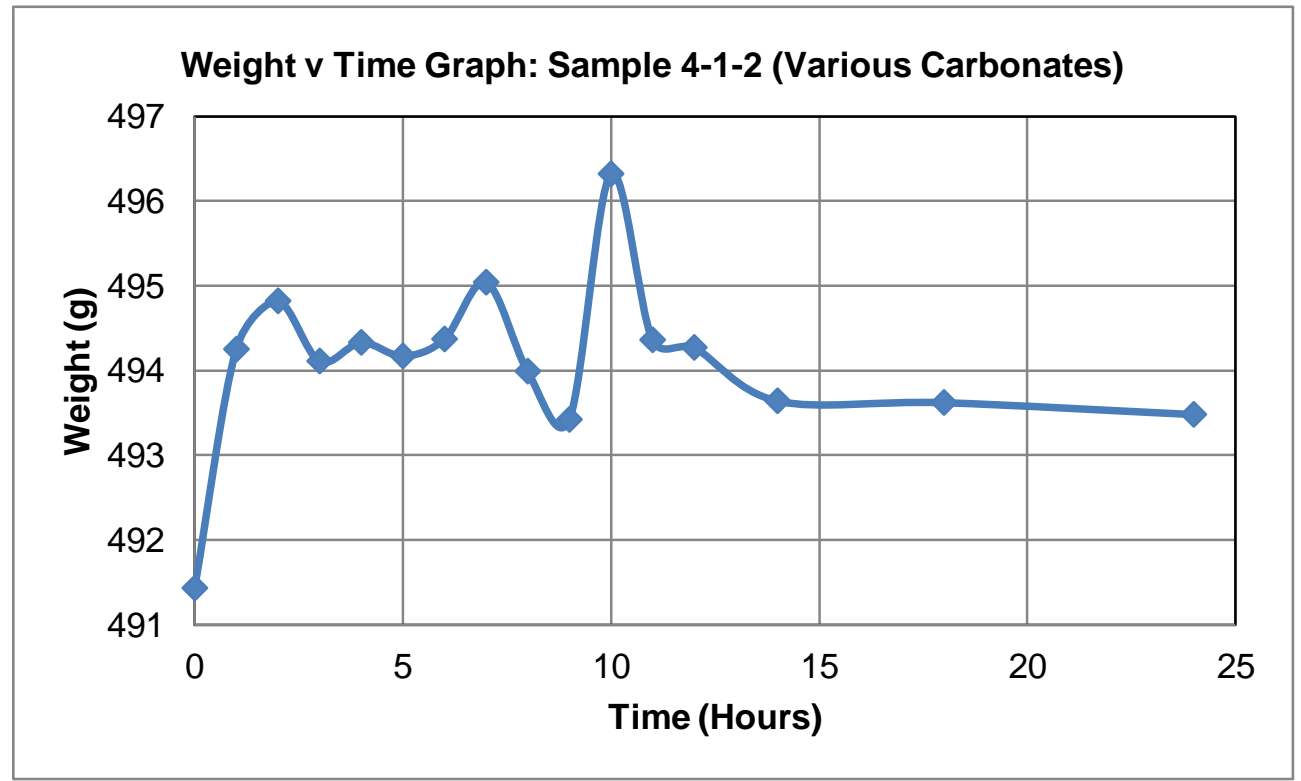

Figure H-8: Weight v Time Graph for sample 4-1-2 (Various Carbonates) 


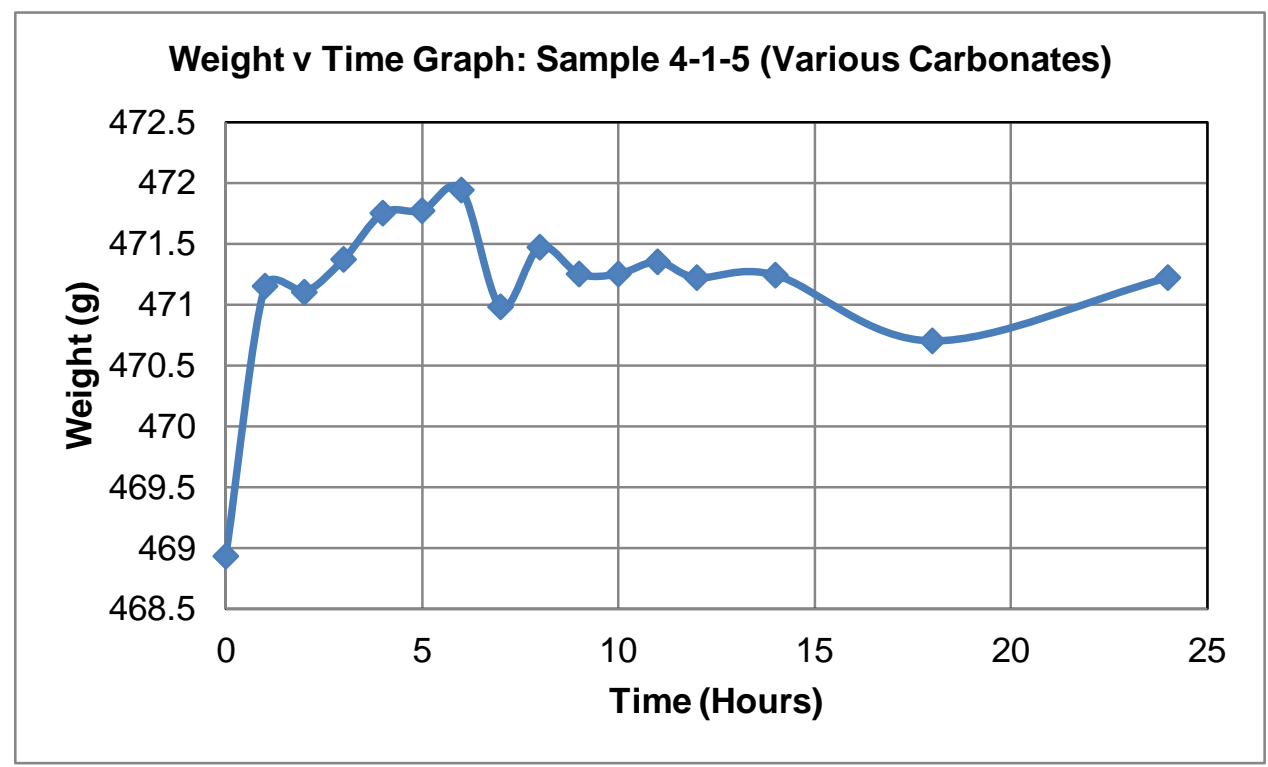

Figure H-9: Weight v Time Graph for sample 4-1-5 (Various Carbonates)

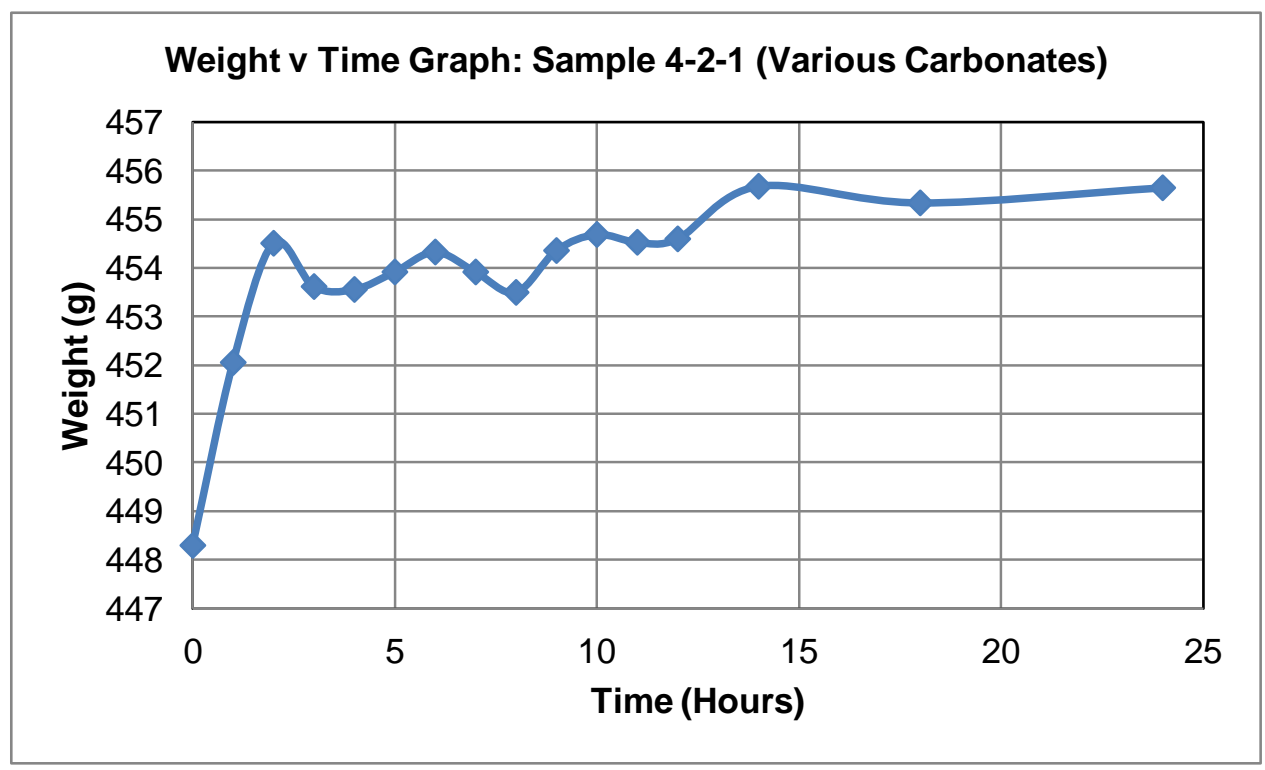

Figure H-10: Weight v Time Graph for sample 4-2-1 (Various Carbonates) 


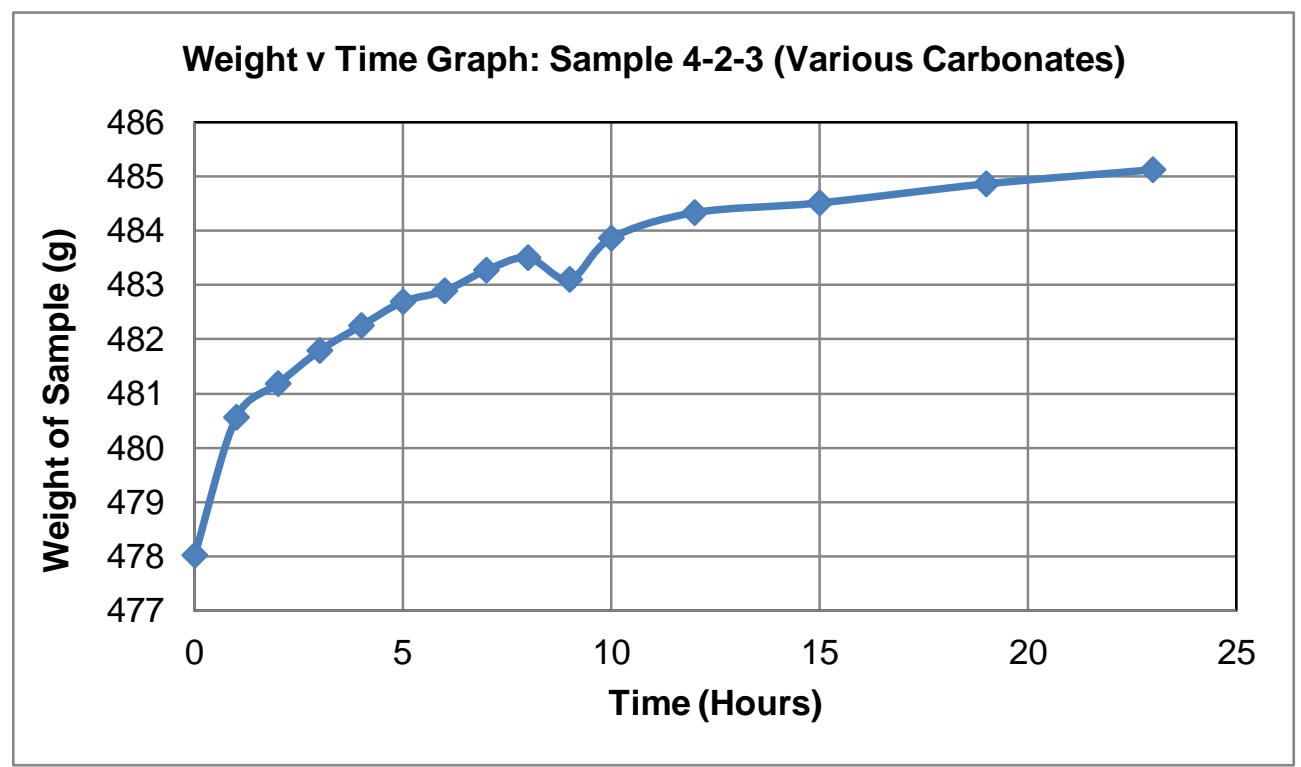

Figure H-11: Weight v Time Graph for sample 4-2-3 (Various Carbonates)

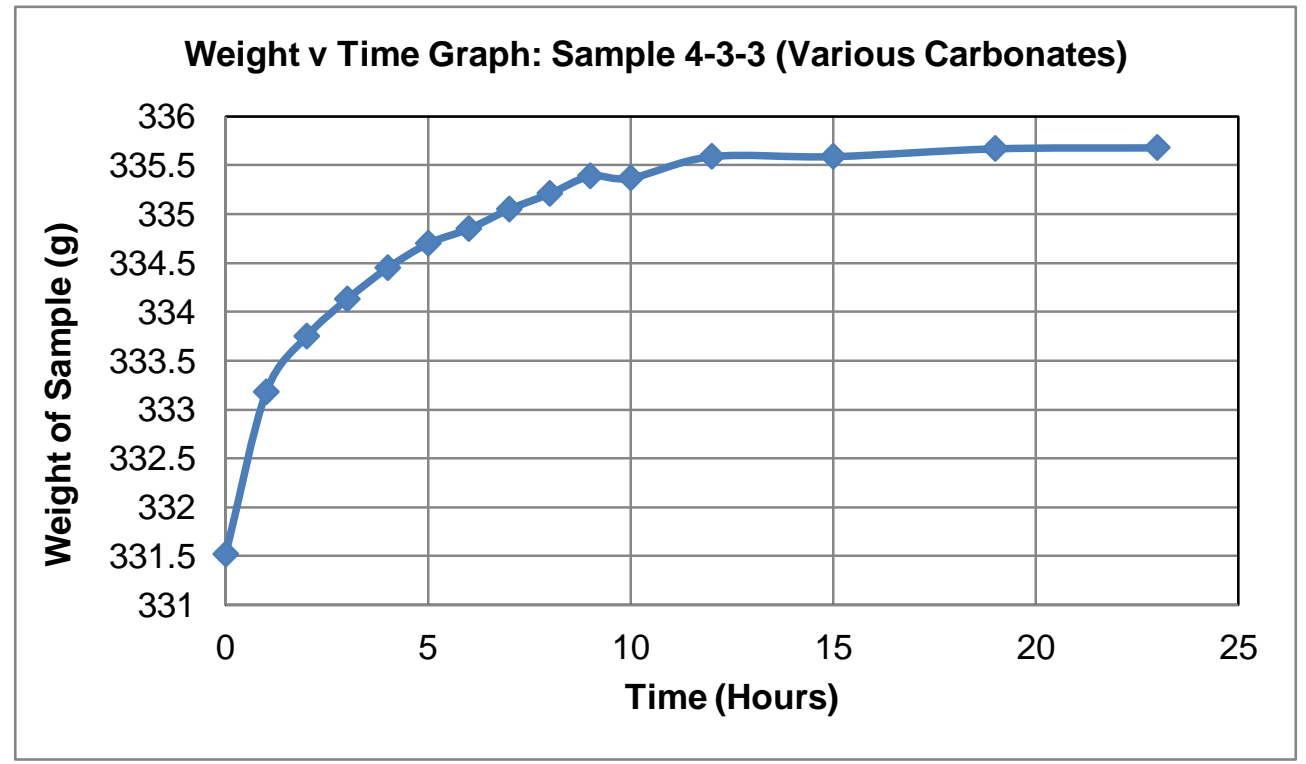

Figure H-12: Weight v Time Graph for sample 4-3-3 (Various Carbonates) 


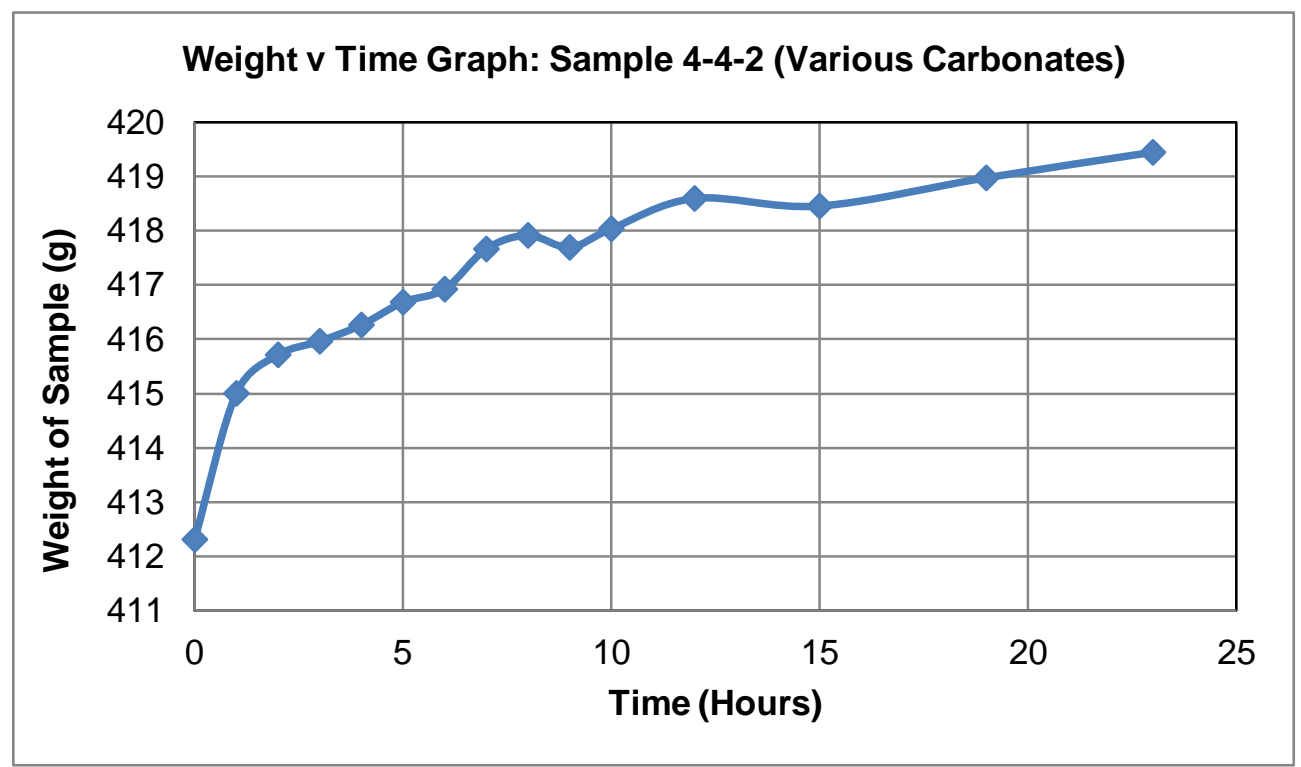

Figure H-13: Weight v Time Graph for sample 4-4-2 (Various Carbonates)

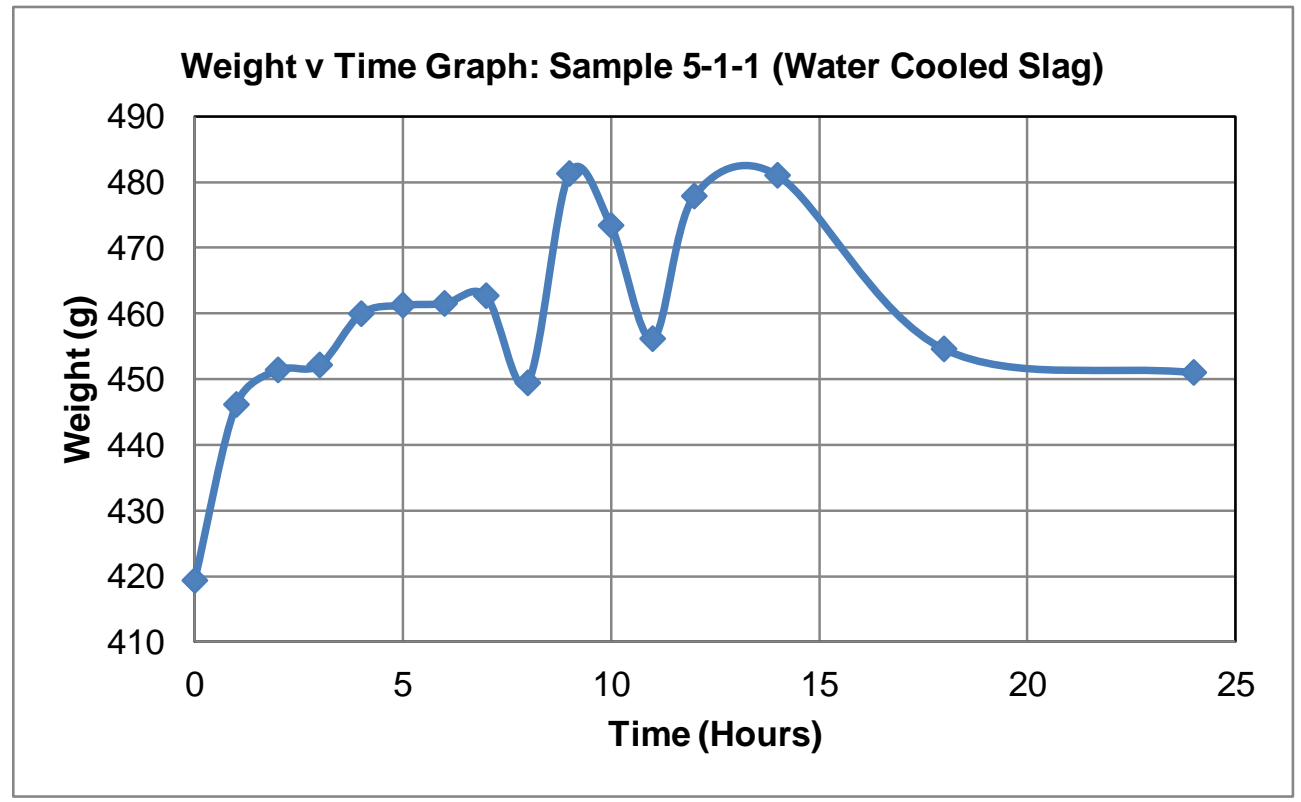

Figure H-14: Weight v Time Graph for sample 5-1-1 (Water Cooled Slag) 


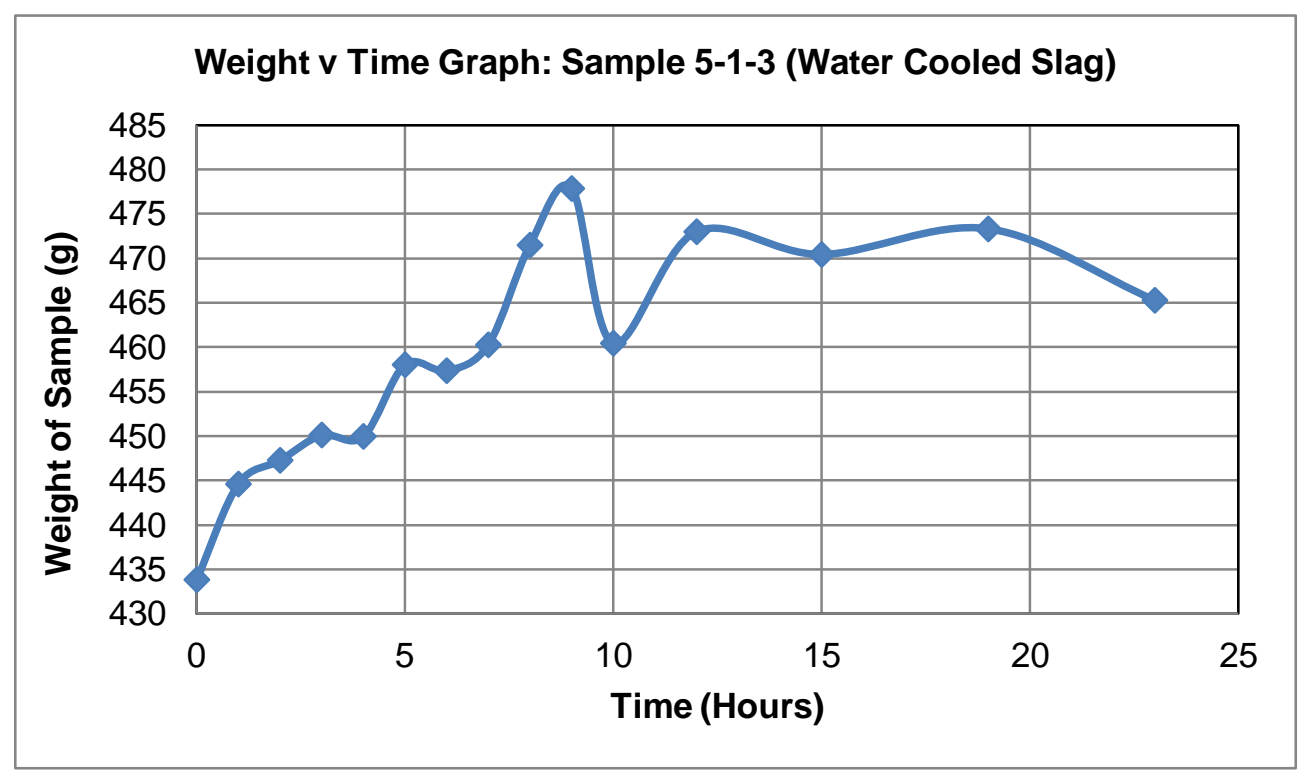

Figure H-15: Weight v Time Graph for sample 5-1-3 (Water Cooled Slag)

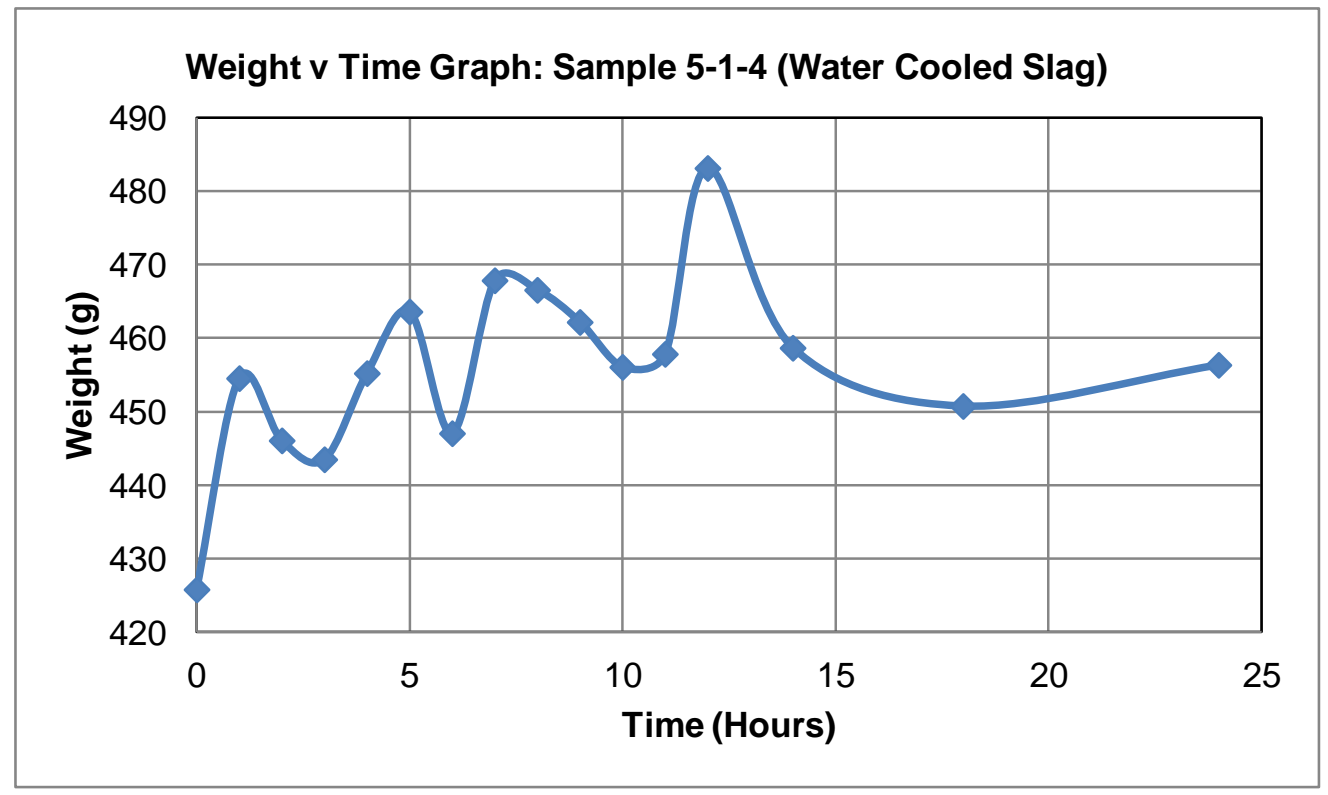

Figure H-16: Weight v Time Graph for sample 5-1-4 (Water Cooled Slag) 


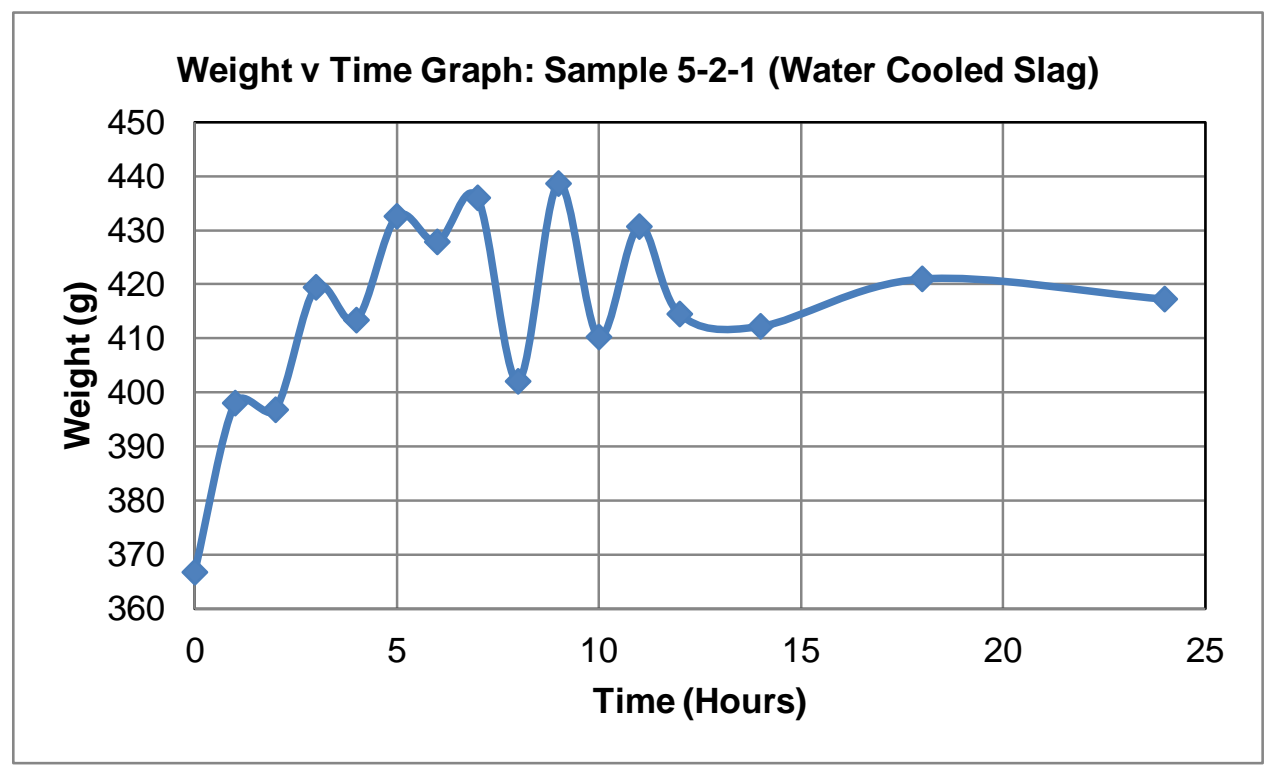

Figure H-17: Weight v Time Graph for sample 5-2-1 (Water Cooled Slag)

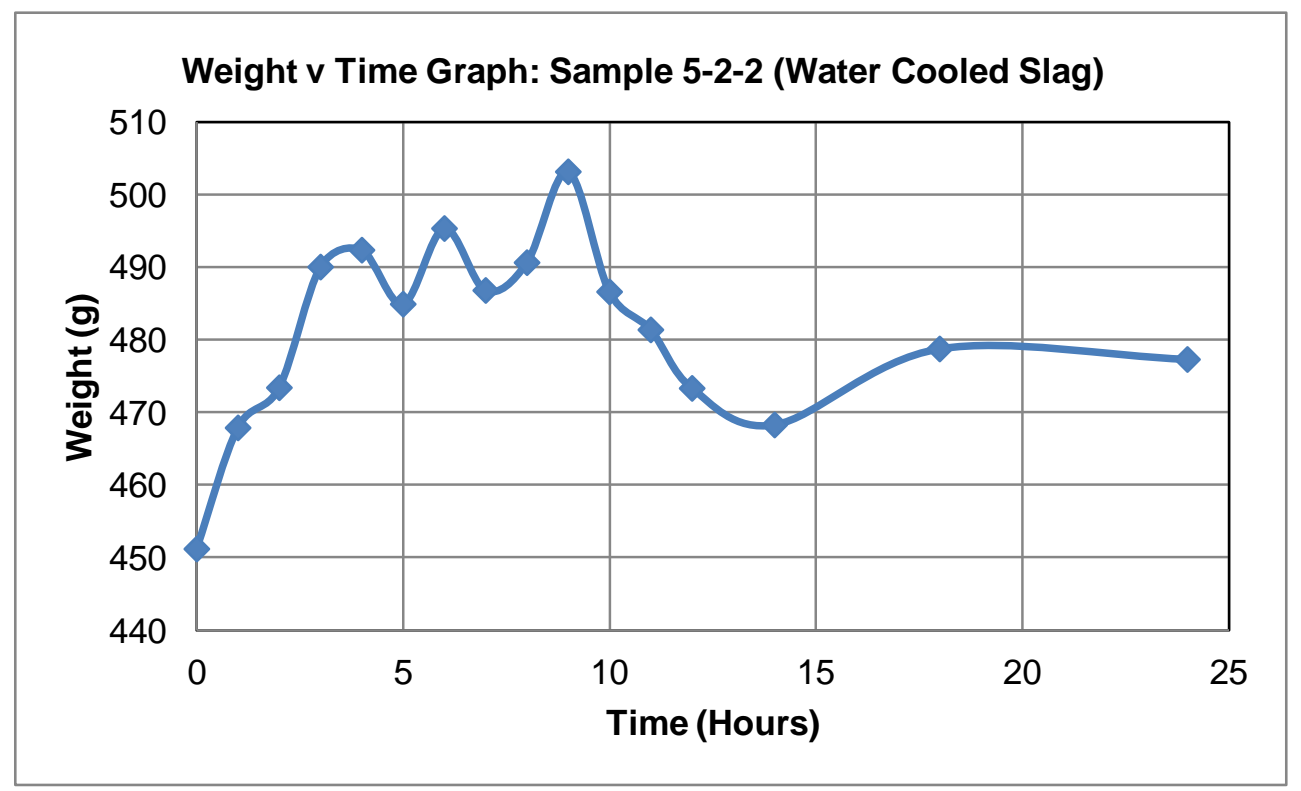

Figure H-18: Weight v Time Graph for sample 5-2-2 (Water Cooled Slag) 


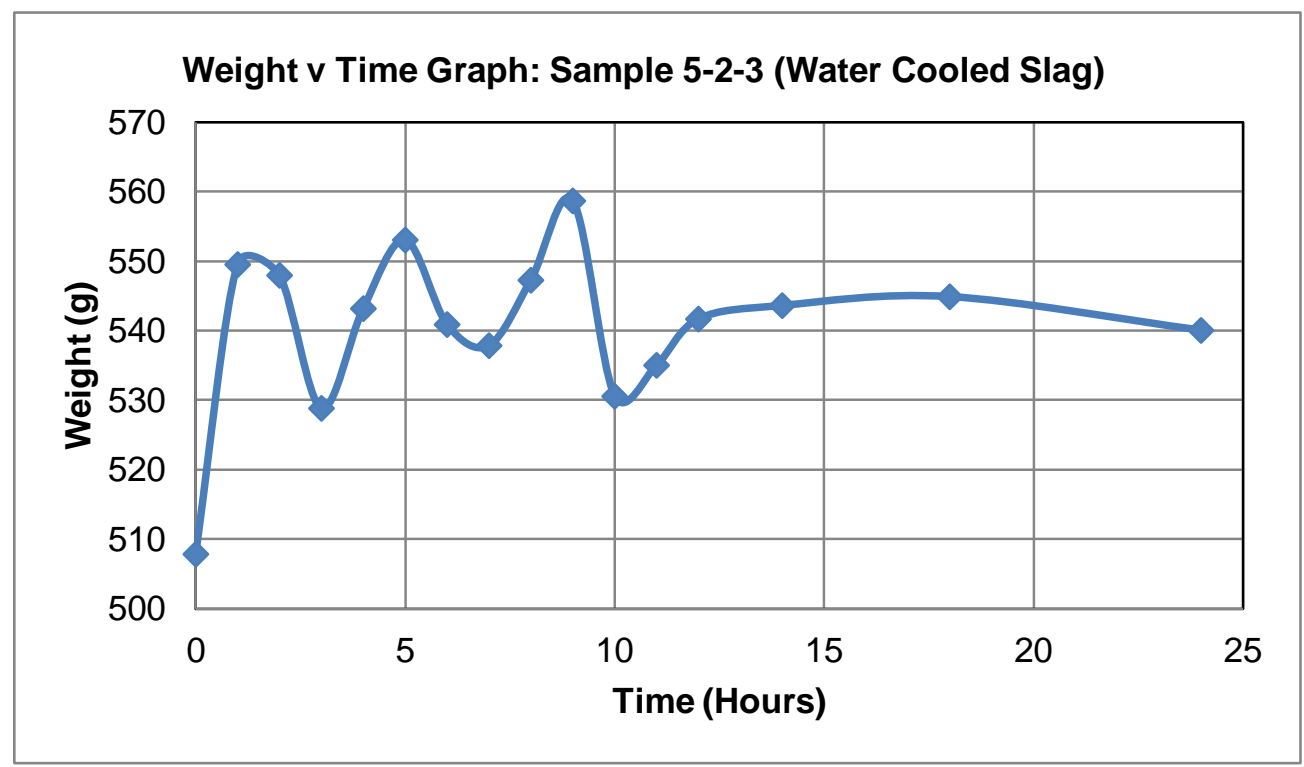

Figure H-19: Weight v Time Graph for sample 5-2-3 (Water Cooled Slag)

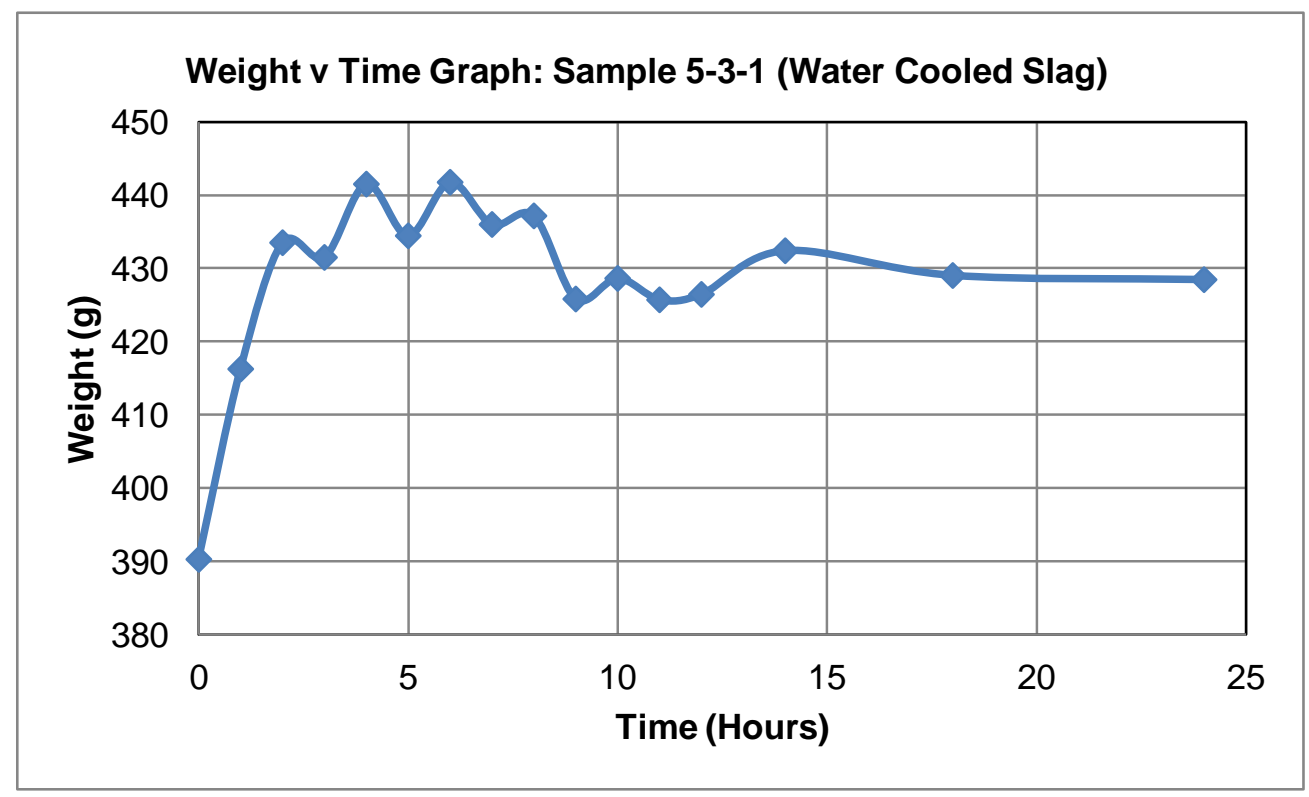

Figure H-20: Weight v Time Graph for sample 5-3-1 (Water Cooled Slag) 


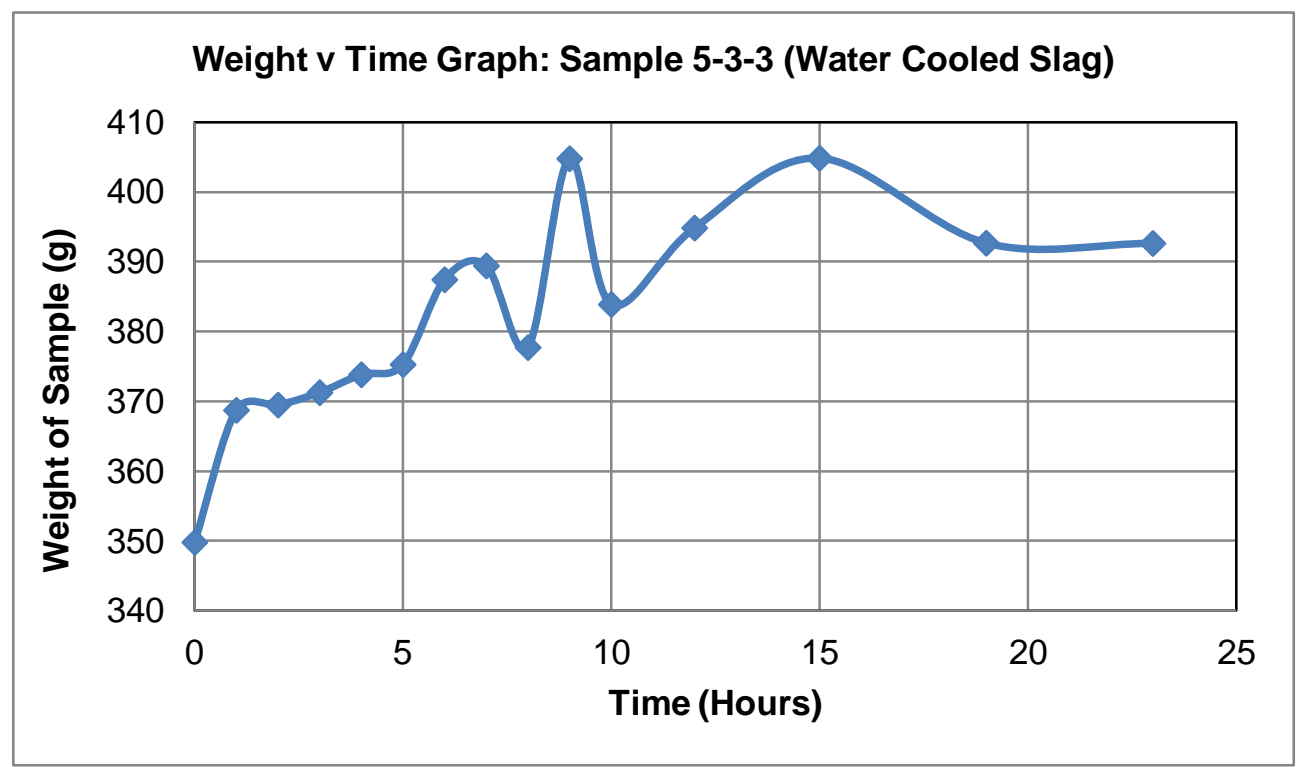

Figure H-21: Weight v Time Graph for sample 5-3-3 (Water Cooled Slag)

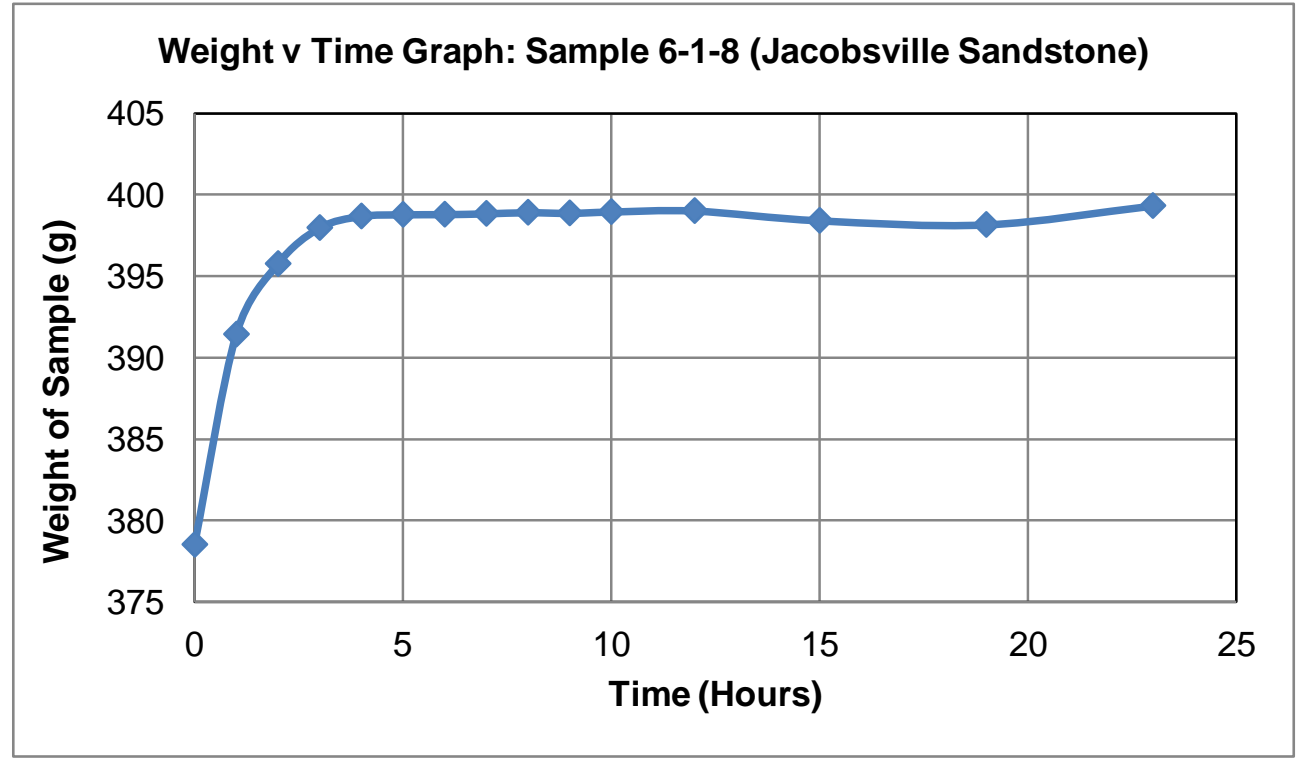

Figure H-22: Weight v Time Graph for sample 6-1-8 (Jacobsville Sandstone) 


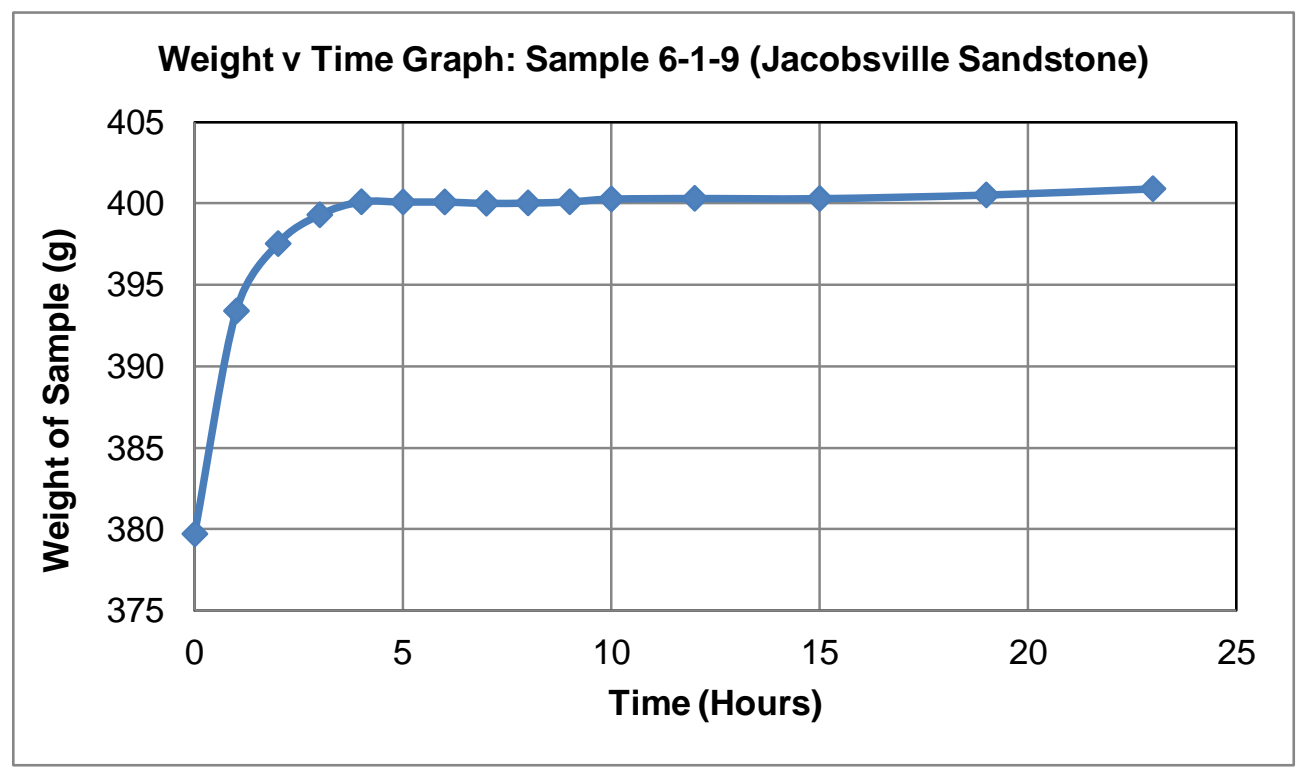

Figure H-23: Weight v Time Graph for sample 6-1-9 (Jacobsville Sandstone)

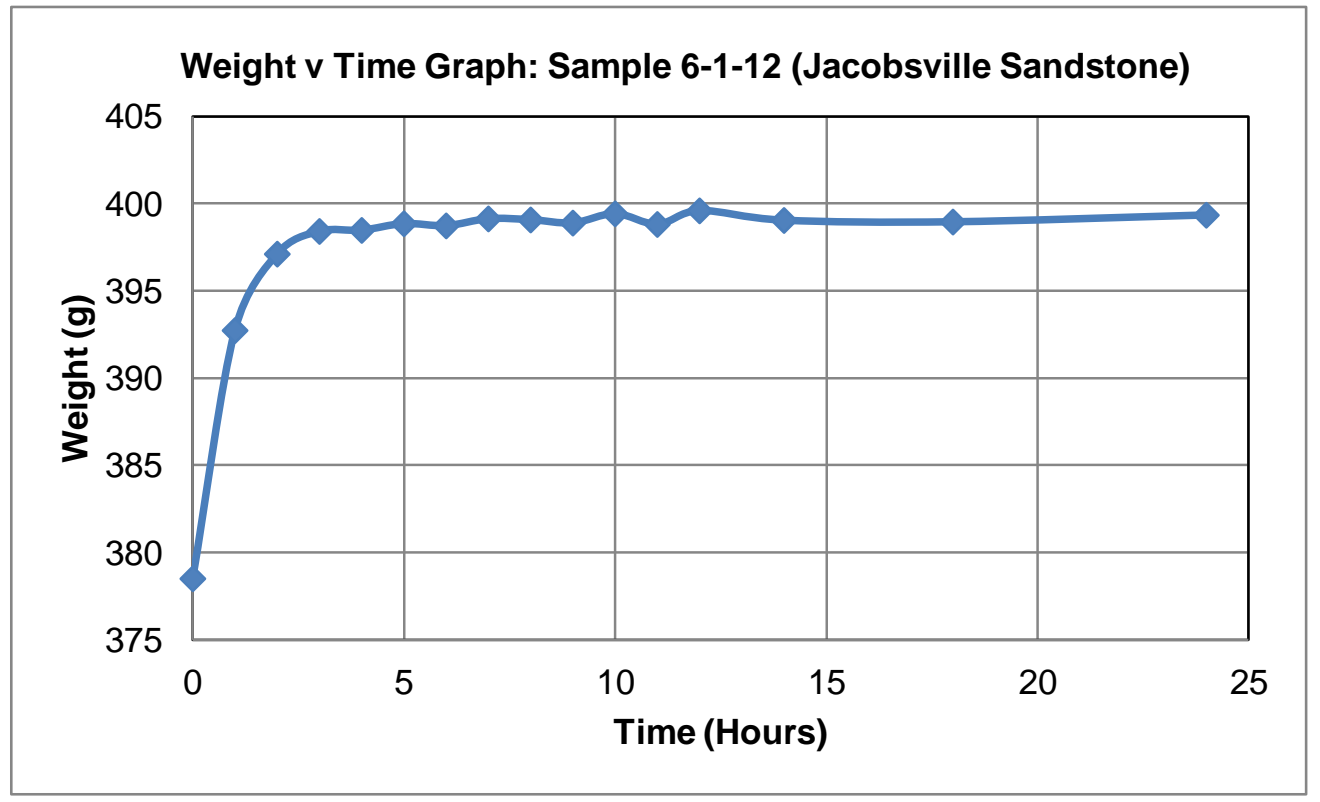

Figure H-24: Weight v Time Graph for sample 6-1-12 (Jacobsville Sandstone) 


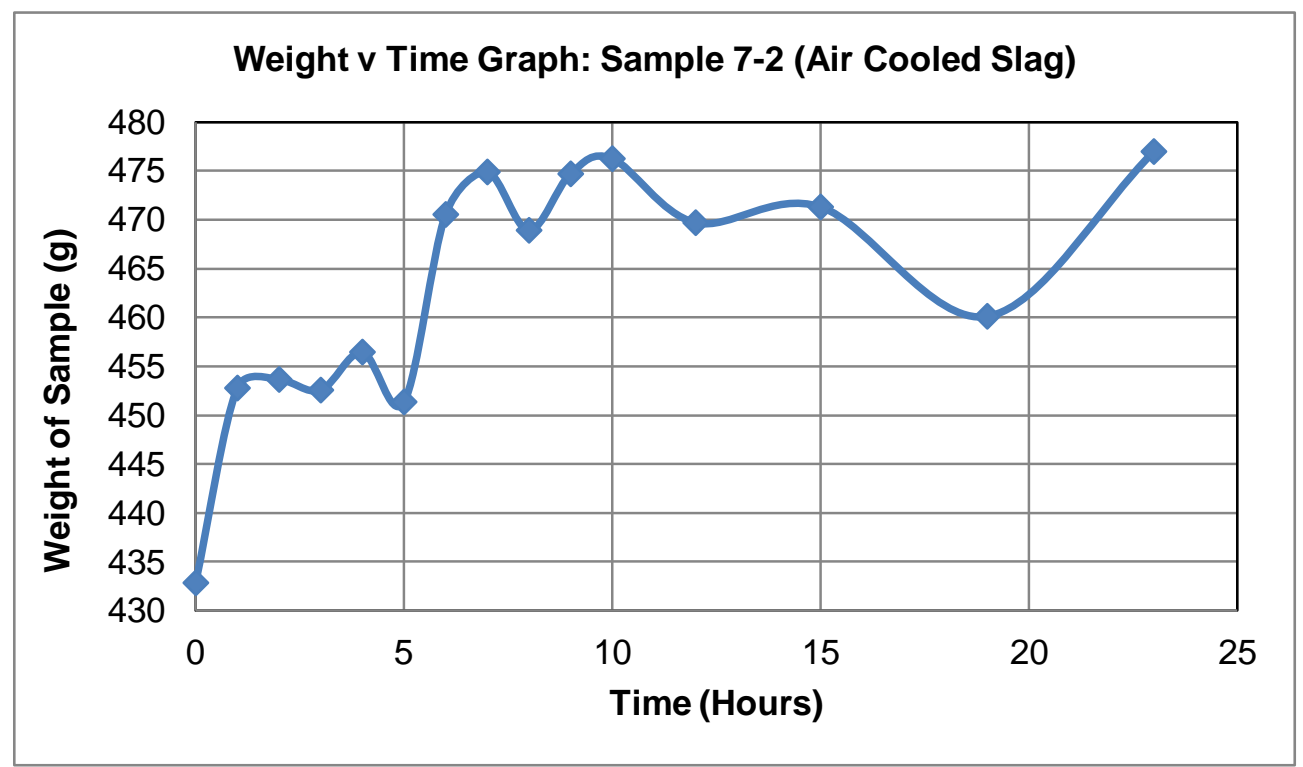

Figure H-25: Weight v Time Graph for sample 7-2 (Air Cooled Slag)

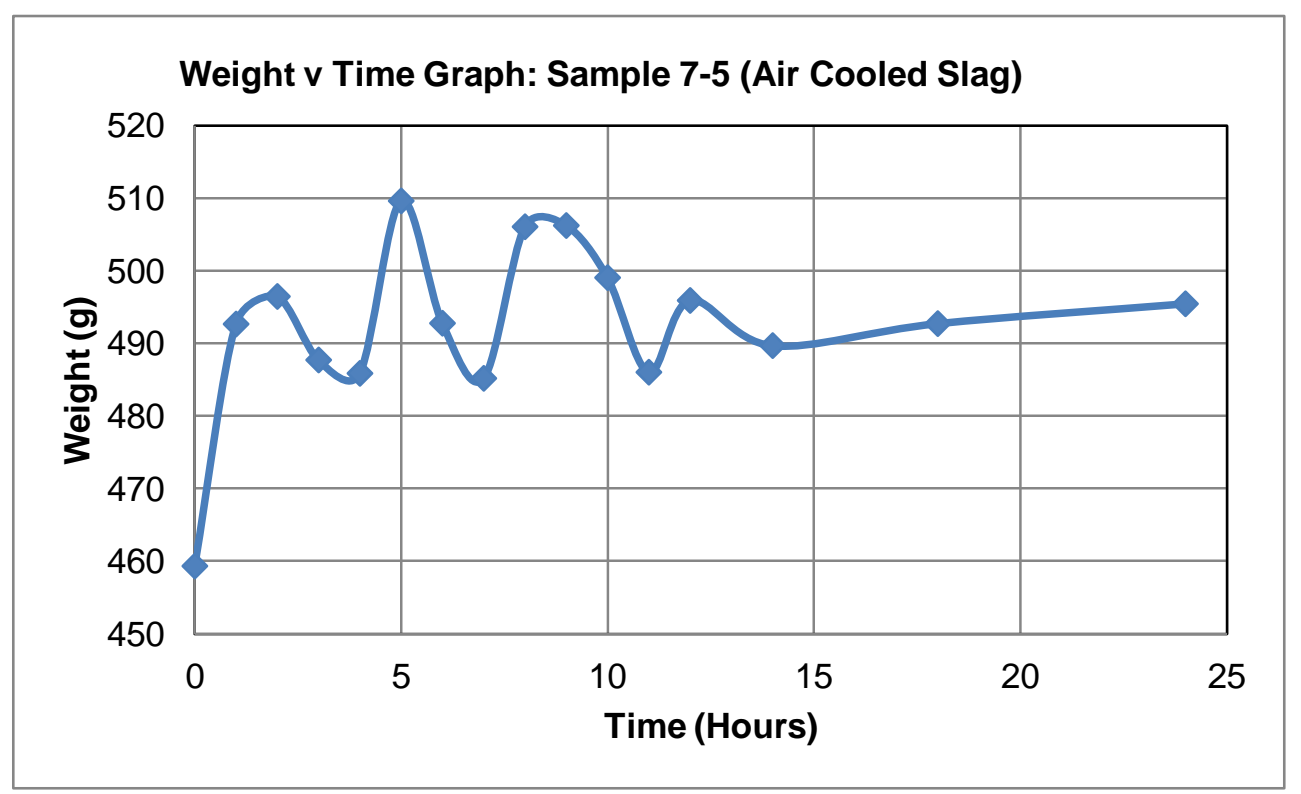

Figure H-26: Weight v Time Graph for sample 7-5 (Air Cooled Slag) 
8.1.1

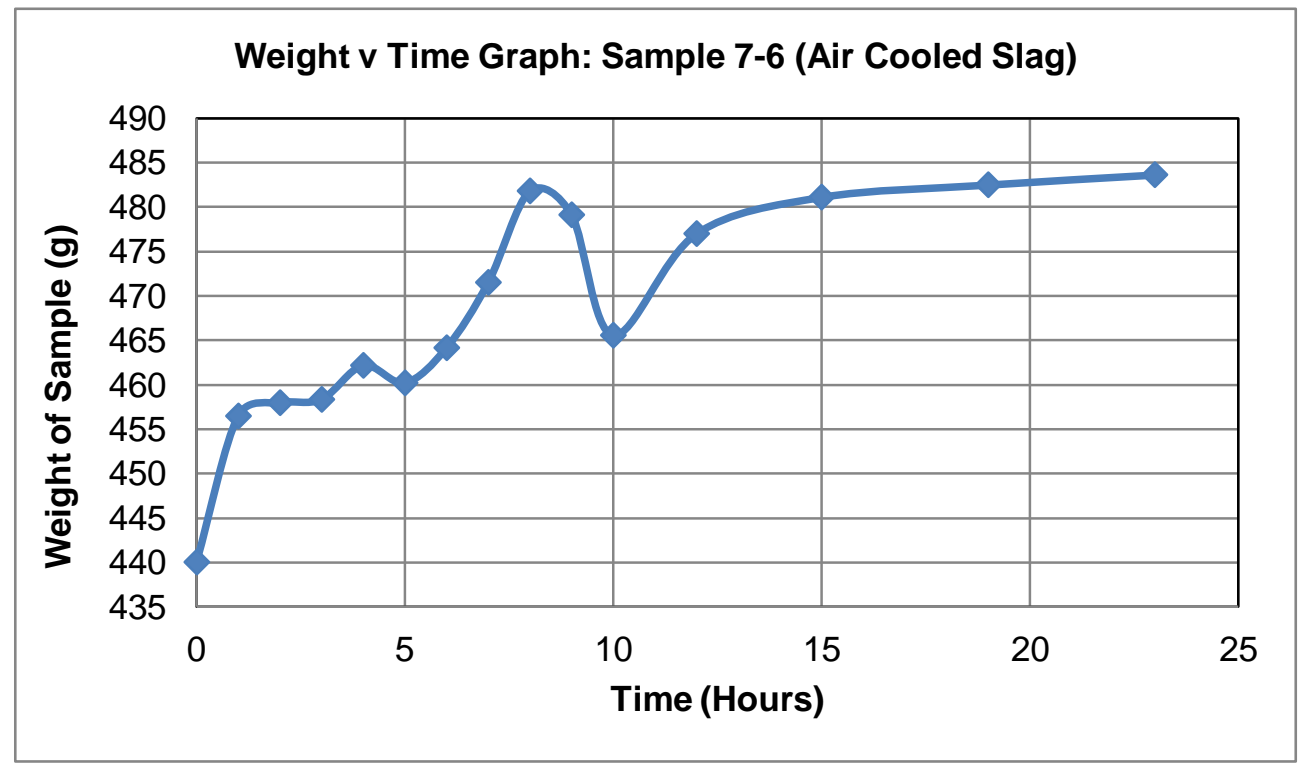

Figure H-27: Weight v Time Graph for sample 7-6 (Air Cooled Slag) 